UNIVERSIDADE DE SÃO PAULO

INSTITUTO DE PSICOLOGIA

PAULINE DE MELLO MARTINES

GRUPOS VIVENCIAIS DE SONHOS COM ESTUDANTES DE PSICOLOGIA: UMA PROPOSTA PARA O AUTOCONHECIMENTO E ALTERIDADE. 


\section{PAULINE DE MELLO MARTINES}

Grupos vivenciais de sonhos com estudantes de psicologia: uma proposta para o autoconhecimento e alteridade.

\section{Versão Corrigida}

Dissertação apresentada ao Instituto de Psicologia da Universidade de São Paulo para obtenção do título de Mestre em Psicologia.

Área de Concentração: Psicologia Escolar e do Desenvolvimento Humano

Orientadora: Profa. Dra. Laura Villares de Freitas

\section{São Paulo}

2017 
AUTORIZO A REPRODUÇÃO E DIVULGAÇÃO TOTAL OU PARCIAL DESTE TRABALHO, POR QUALQUER MEIO CONVENCIONAL OU ELETRÔNICO, PARA FINS DE ESTUDO E PESQUISA, DESDE QUE CITADA A FONTE.

Catalogação na publicação

Biblioteca Dante Moreira Leite

Instituto de Psicologia da Universidade de São Paulo

Martines, Pauline de Mello.

Grupos vivenciais de sonhos com estudantes de psicologia: uma proposta para o autoconhecimento e alteridade. / Pauline de Mello Martines; orientadora Laura Villares de Freitas. -- São Paulo, 2017.

$182 \mathrm{f}$.

Dissertação (Mestrado - Programa de Pós-Graduação em Psicologia. Área de Concentração: Psicologia da Aprendizagem, do Desenvolvimento e da Personalidade) - Instituto de Psicologia da Universidade de São Paulo.

1. Sonhos 2. Grupos vivenciais 3. Formação do psicólogo 4. Psicologia analítica de Jung I. Título.

RC506 
Nome: MARTINES, Pauline de Mello

Título: Grupos vivenciais de sonhos com estudantes de psicologia: uma proposta para o autoconhecimento e alteridade.

Dissertação apresentada ao Instituto de Psicologia da Universidade de São Paulo para obtenção do título de Mestre em Psicologia.

Aprovado em:

Banca Examinadora

Prof. Dra.: Instituição:

Julgamento: Assinatura:

Prof. Dra.: Instituição:

Julgamento: Assinatura:

Prof. Dra.: Instituição:

Julgamento: Assinatura: 
Para Lúcia e Luís, por me incentivarem a sonhar.

Para Marco, por sonhar comigo.

Para todos os sonhadores. 


\section{AGRADECIMENTOS}

Aos meus amados pais, Lúcia e Luís, por todo o amor e por acreditarem em mim e nos meus sonhos, desde cedo, e pela enorme compreensão, incentivo e paciência. Por todas as conversas ao longo da noite, com choros e risos. Por todo o apoio que preciso e que precisei.

Ao Marco, meu amor, por todo o cuidado e carinho, por me iluminar e me "tirar do ar" de vez em quando, para me fazer rir e desejar novos sonhos, juntos.

À Prof. Dra. Laura Villares de Freitas, pela sua presença tão querida nesses quase oito anos de sonhos compartilhados.

Aos participantes desta pesquisa, sem os quais ela não teria sido realizada e muito menos tão viva e intensa como foi.

Ao CNPQ pelo financiamento à pesquisa, o que permitiu a sua realização.

À Yara Kilsztain, pela sua disponibilidade e carinho, além das muitas conversas sobre sonhos no corredor.

À Prof. Dra. Maria Júlia Kovács pela troca de experiências e valiosas contribuições.

À Prof. Dra. Rosane Rodrigues, pela possibilidade do novo e da exploração.

À Tânia Pessoa de Lima, do Laboratório de Estudos da Personalidade - LEP USP, pelo suporte na realização do grupo.

Ao Instituto de Psicologia da Universidade de São Paulo, por abrigar novas iniciativas e interlocuções.

Aos funcionários da Sala Ateliê, pelas ajudas e sorrisos.

Aos funcionários da biblioteca do Instituto de Psicologia da USP, a qual frequentei assiduamente, por toda a dedicação e presteza. 
A todos aqueles que pude conhecer e trabalhar no consultório durante a realização desta dissertação, pelo interesse, estímulo e compreensão.

Aos meus alunos, pela grata surpresa e por mostrarem um novo e desafiante caminho a ser percorrido.

Aos meus amigos, novos e antigos, próximos e distantes, pelas conversas, abraços, confidências e sonhos, muitos sonhos compartidos.

Aos meus familiares, por toda a torcida, em especial ao meu avô Jorge, pela curiosidade, alegria e apoio, e às minhas avós, Anna, de quem sinto bonitas saudades e com quem aprendi a importância do cuidar e Anézia, que sempre parece ler meus pensamentos e me ajuda a ter confiança em mim e nos ciclos da vida. 
Apesar das ruínas e da morte, Onde sempre acabou cada ilusão, A força dos meus sonhos é tão forte, Que de tudo renasce a exaltação E nunca as minhas mãos ficam vazias. Sophia de Mello Breyner Andresen, 2011. 


\section{RESUMO}

MARTINES, Pauline de Mello. Grupos vivenciais de sonhos com estudantes de psicologia. 2017. 182f. Dissertação (Mestrado em Psicologia Escolar e do Desenvolvimento Humano) Instituto de Psicologia, Universidade de São Paulo, São Paulo, 2017.

A presente dissertação fundamenta-se na psicologia analítica, criada pelo psiquiatra e psicanalista suíço Carl Gustav Jung. Partindo deste referencial e tomando como base os pilares da pesquisa qualitativa foi realizado um grupo vivencial de sonhos com estudantes ingressantes no $1^{\circ}$ ano de graduação em Psicologia de uma universidade pública, com o objetivo de compreender como os estudantes estão vivenciando esse momento específico. Por meio do estudo do movimento grupal nos encontros, de uma análise do material obtido e da elaboração simbólica a respeito do desenvolvimento do grupo e dos encontros foi possível identificar e observar símbolos que apontam para um período de mudanças e enfrentamento de angústias e medos, encontrando sustentação e significação no grupo. $\mathrm{O}$ grupo vivencial com a utilização de recursos expressivos artísticos revelou-se também como meio de autoconhecimento, possibilitando o exercício da alteridade e seu manejo, indicando seu uso durante a formação do psicólogo em diversos momentos.

Palavras-chave: sonhos; grupos vivenciais; formação do psicólogo; psicologia analítica de Jung. 


\begin{abstract}
The present dissertation is based on analytical psychology, created by the Swiss psychiatrist and psychoanalyst Carl Gustav Jung. Starting from this framework and based on the pillars of qualitative research, an experiential dream group was realized with incoming students in the first year of graduation in Psychology from a public university, in order to understand how the students are experiencing this moment. Through the study of the group movement in the meetings, an analysis of the material obtained and the symbolic elaboration of the same and of the encounters, it was possible to identify and observe symbols that refer to a process of change and confrontation of fears that found support in the group. The experiential group with expressives artistcs resources revealed itself also as a tool for self-knowledge, allowing the exercise of alterity and its management, its use being indicated for the training of psychologists, in several moments.
\end{abstract}

Key-words: dreams; analytical psychology; experiential groups; psychologist training. 


\section{SUMÁRIO}

1. APRESENTAÇÃO ......................................................................................................... 14

2. EMBASAMENTO TEÓRICO ...................................................................................... 19

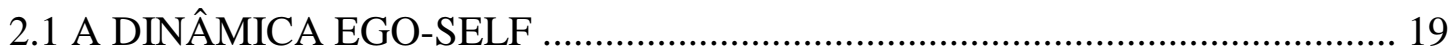

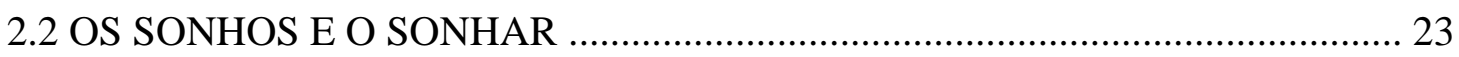

2.3 ESTRUTURA DRAMÁTICA ONÍRICA ………………................................. 30

2.4 OS SÍMBOLOS E A FUNÇÃO TRANSCENDENTE ............................................31

2.5 AS DUAS FORMAS DE PENSAMENTO E O ENCONTRO COM A

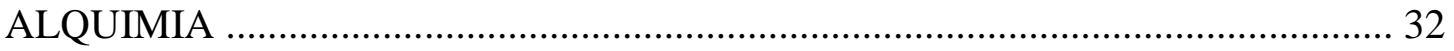

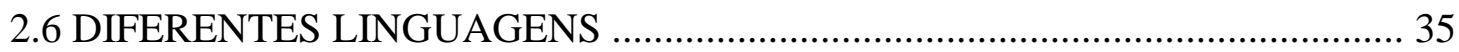

2.7 OS ARQUÉTIPOS DO MESTRE-APRENDIZ E DO CURADOR-FERIDO 38

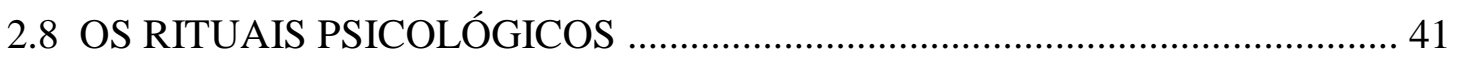

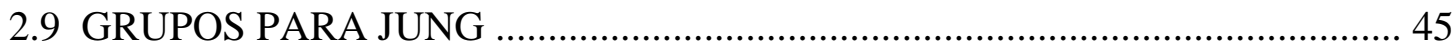

2.9.1 GRUPOS VIVENCIAIS NA PSICOLOGIA ANALÍTICA ………..... 47

2.10 CONTRIBUIÇÕES DO PSICODRAMA ……………………………........ 53

3. O PROJETO DE PESQUISA …...................................................................................... 56

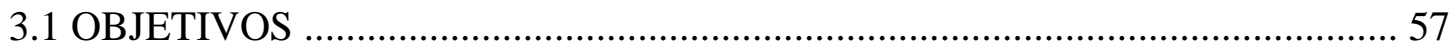

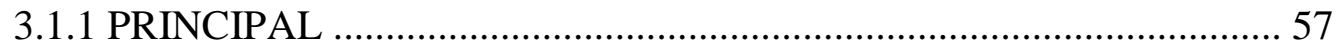

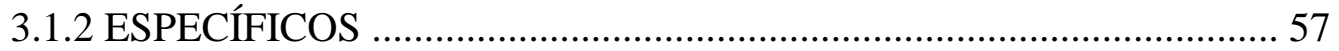

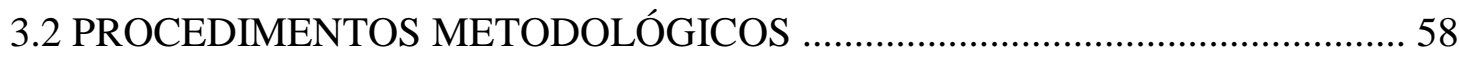

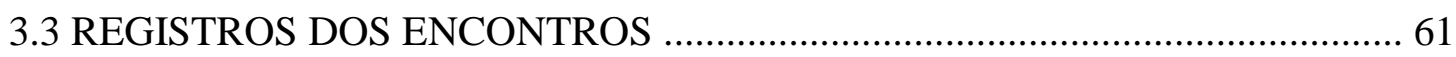

3.3.1 RECURSOS DOS ENCONTROS …………………………………..... 62

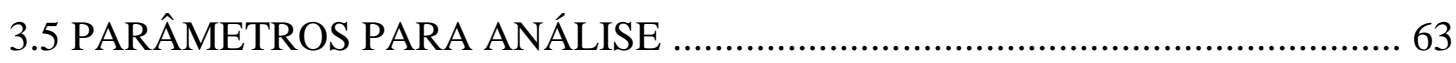


3.5 A CONSTITUIÇÃO DO GRUPO VIVENCIAL 64

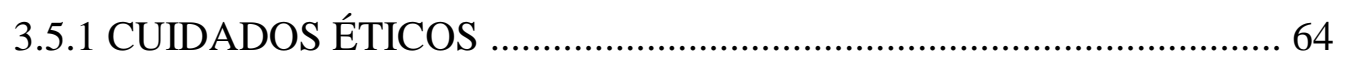

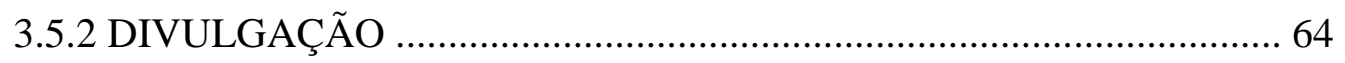

3.5.3 FORMAÇÃO DO GRUPO VIVENCIAL DE SONHOS ........................ 65

3 OS ENCONTROS VIVENCIAIS E OS RESULTADOS DA PESQUISA .......... 66

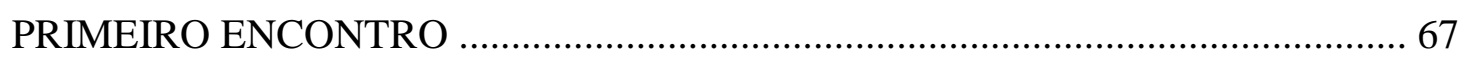

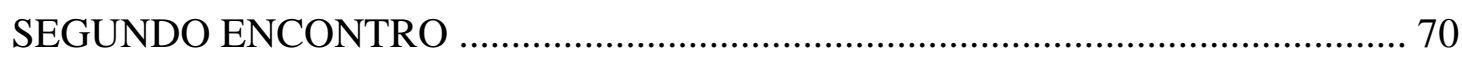

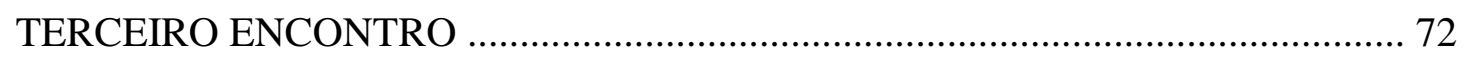

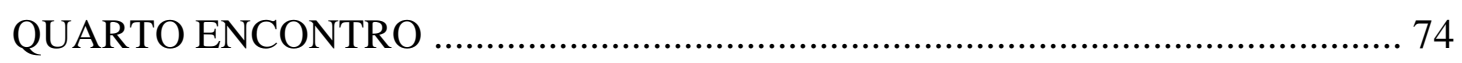

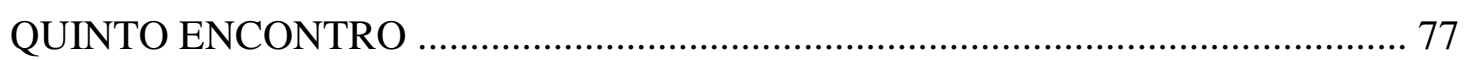

4 OS RESUltados E SUA ANÁlise: UM PERCURSO DE ELABORAÇÃo SIMBÓLICA ................................................................................................................. 79

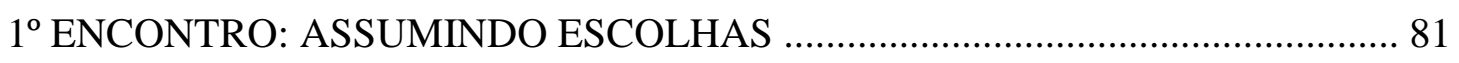

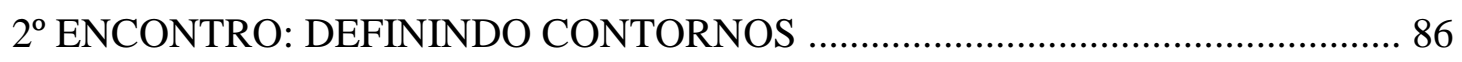

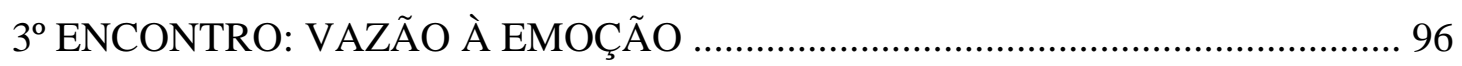

$4^{\circ}$ ENCONTRO: DESCOBRINDO POSSIBILIDADES ......................................... 108

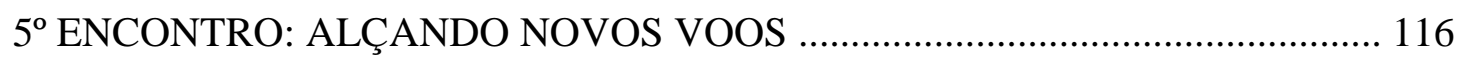

CONTRIBUIÇÕES DO QUESTIONÁRIO FINAL ……………………………..... 127

6. NOVOS HORIZONTES ........................................................................................ 132

7. CONSIDERAÇÕES FINAIS .................................................................................. 139

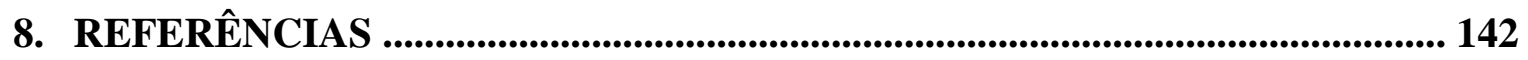

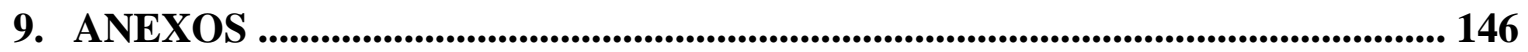

ANEXO A: CONVITE PARA PARTICIPAÇÃO ……………………………..... 146

ANEXO B: TERMO DE CONSENTIMENTO LIVRE E ESCLARECIDO ..............147

ANEXO C: RESULTADOS DO $1^{\circ}$ ENCONTRO .............................................. 148 
ANEXO D: SONHOS ESCRITOS NO $1^{\circ}$ ENCONTRO

ANEXO E: RESULTADOS DO $2^{\circ}$ ENCONTRO

ANEXO F: DESENHOS DO $2^{\circ}$ ENCONTRO

ANEXO G: RESULTADOS DO $3^{\circ}$ ENCONTRO

ANEXO H: RESULTADOS DO $4^{\circ}$ ENCONTRO 162

ANEXO I: MODELAGENS E SEUS RESPECTIVOS SONHOS 165

ANEXO J: SONHOS REFERENTES AOS $2^{\circ}$ E $3^{\circ}$ ENCONTROS 173

ANEXO K: RESPOSTAS DO QUESTIONÁRIO FINAL 175 


\title{
1. APRESENTAÇÃO
}

\begin{abstract}
Todo conhecimento começa com um sonho. O conhecimento nada mais é que a aventura pelo mar desconhecido, em busca da terra sonhada. Mas sonhar é coisa que não se ensina. Brota das profundezas da alma como a água que brota das profundezas da terra. Como mestre, só posso lhes dizer uma coisa:

- Conte-me seus sonhos para que sonhemos juntos. ${ }^{1}$
\end{abstract}

Rubem Alves

Acredito que toda pesquisa, ou melhor, toda jornada, nasce com o desejo do coração.

A importância e a influência dos sonhos na minha vida pessoal sempre se fizeram presentes e, assim, foram permeando também meu percurso profissional e acadêmico. $\mathrm{O}$ contato com diversas experimentações artísticas em aulas optativas na Escola de Comunicações e Artes da Universidade de São Paulo - USP, e no estágio realizado no Museu de Arte Contemporânea da USP também esteve presente durante minha formação e se encontra entrelaçado aqui também.

A origem desta dissertação se deu oito anos atrás, no segundo ano da minha graduação em psicologia, em 2009. Um grupo de amigos e colegas de curso e eu estávamos interessados no estudo dos sonhos a partir da abordagem da psicologia analítica, tomando como material a nossa própria experiência pessoal com nossos sonhos, e nos constituindo enquanto um grupo. Esta inovadora pesquisa, que intitulamos Estudando os Sonhos: Processos Vivenciais, Teóricos e Expressivos, realizou-se durante as disciplinas de Prática de Pesquisa em Psicologia sob orientação da Prof. Dra. Laura Villares de Freitas, agora minha orientadora nesta dissertação de mestrado.

Durante a pesquisa experimental foi possível: explorar recursos expressivos e artísticos como desenhos, colagens, culinária e assemblages $^{2}$, na tentativa de compreender e ampliar o conteúdo dos sonhos; fazer leituras sobre textos junguianos e uma primeira elaboração nossa sobre metodologia de análise dos sonhos com designação de títulos, emoções despertadas, associações e comentários do grupo; e ao final, entre 2011 e 2012, a pesquisa desdobrou-se para um momento em que se tornou possível realizar atendimento

\footnotetext{
${ }^{1}$ Disponível em https://pensador.uol.com.br/conhecimento_rubem_alves/

${ }^{2}$ Termo artístico para colagens com materiais tridimensionais.
} 
psicológico à comunidade dentro da clínica-escola do Instituto de Psicologia da Universidade de São Paulo - IPUSP com supervisão de abordagem junguiana em grupo.

Além disso, foi possível vivenciar uma experiência que ultrapassou o âmbito do conhecimento intelectual adquirido e transformou-se em um vínculo construído e esse grupo de pesquisa alcançou vida própria e movimento genuíno. Através da confiança conquistada e construída em cada relato de sonho, do respeito mútuo a cada vez que percebíamos que estávamos nos abrindo muito mais do que imaginávamos ao contar nossos sonhos, do reconhecimento das nossas resistências à exposição e da identificação silenciosa e amigável das nossas maiores dificuldades e medos foi possível articular a teoria com a prática no estudo da psicologia analítica, abrindo-nos também para uma experiência de confidência e responsabilidade.

O uso de recursos expressivos auxiliou tanto na compreensão e elaboração dos meus próprios sonhos e questões quanto na observação (através dos sonhos dos meus amigos) do potencial que eles abrigam enquanto acolhedores e transformadores de processos psicológicos.

Essa pesquisa acima mencionada foi apresentada no formato de pôster e café temático no VI Congresso Latino-americano de Psicologia Junguiana no ano de 2012. Hoje, seu processo e sua análise encontram-se também relatados pela Prof. Dra. Laura Villares de Freitas no livro Sonhos na Psicologia Junguiana (FREITAS. In: FARIA; FREITAS; GALLBACH, 2014).

Mas a jornada em mim continuou e, em 2012, prestes a finalizar a graduação tive a oportunidade de realizar uma iniciação científica, a qual foi a continuação de um processo de aprendizado muito intenso e enriquecedor, que se revelou desafiador e inquietante. Nela, tinha o mesmo desejo que me motivaria depois a iniciar o mestrado: formar um grupo vivencial de sonhos com estudantes de psicologia do $1^{\circ}$ ano.

$\mathrm{Na}$ iniciação científica pude realizar um aprofundamento teórico sobre sonhos e grupos vivenciais; uma metodologia de análise composta por questionários iniciais e finais e o planejamento de cada um dos encontros do grupo vivencial, nos quais se previa o uso de recursos artísticos e expressivos para o trabalho com os sonhos.

Para que esse novo grupo fosse realizado era preciso tomar cuidados éticos importantes que proporcionassem um ambiente acolhedor que respeitasse o sigilo e a 
subjetividade dos participantes envolvidos no compartilhamento de sonhos. Sendo assim, era necessário obter a aprovação do Comitê de Ética em Pesquisa com Seres Humanos, a qual ocorreu apenas no mês de junho de 2013. Imediatamente fiz um convite pessoal em uma das aulas obrigatórias do currículo dos estudantes do $1^{\circ}$ ano. Nessa ocasião, 9 alunos se mostraram interessados e responderam a um questionário inicial. Também ficou acordado que o grupo teria início na semana seguinte.

Porém, na semana seguinte, houve uma grande manifestação acerca do transporte público do Estado de São Paulo, com intensa mobilização dos estudantes e apenas um dos interessados compareceu no local e hora marcados. Ainda assim, entrei em contato com os interessados e propus novas possibilidades de horário e chegamos a definir uma nova data. Mas nesta segunda tentativa nenhum dos interessados compareceu, o que indicou a necessidade de concluir a pesquisa, em agosto do mesmo ano, apenas analisando os questionários respondidos na ocasião do meu primeiro contato.

Mesmo sem a efetiva realização da parte prática grupal da iniciação científica foi possível pensar na elaboração de um projeto de intervenção e na maturação do mesmo por meio deste mestrado, que hoje tem um significado ainda maior para mim: a investigação acerca do potencial de grupos vivenciais de sonhos para estudantes de psicologia no que se refere à compreensão e simbolização da experiência de chegada ao curso.

Nos últimos anos, a crescente procura pelo curso de Psicologia nas principais universidades públicas do estado de São Paulo se faz notar. No vestibular da FUVEST, responsável pela seleção dos calouros da Universidade de São Paulo - USP, a relação candidato/vaga vem aumentando: em 2013, o número era de 37,87; em 2014 passou para 48,57; já em 2015 mostrou uma leve queda, 40,69; e em 2016 o número surpreendente de 59,8, ultrapassando assim, o tradicional curso de Medicina de São Paulo, com 58,75, historicamente o mais concorrido, ficando atrás somente do curso de Medicina no campus de Ribeirão Preto com 71,93 candidatos por vaga.

Já no vestibular da VUNESP, responsável pela seleção dos calouros da Universidade Júlio de Mesquita Filho - UNESP, o curso de Psicologia no campus de Bauru, um dos mais reconhecidos desta Universidade, também se encontra entre os três cursos mais disputados. Em 2016, o número era de 44,4, em 2015 era 38,9, em 2014 este número era de 34 candidatos por vaga e em 2013 foi registrado 30,9. 
A partir destas informações, evidencia-se a crescente procura pelo curso, fato que em si revela mudanças quanto às aspirações profissionais dos jovens estudantes.

O que poderia justificar tal aumento pela procura do curso de psicologia? Seria um meio de buscar autoconhecimento e "se encontrar" no mundo? Seria uma forma de promover ajuda à população? Em que medida estaria esta procura relacionada à vivência de sofrimento, medo e angústia pelos próprios estudantes? Enfim, como estão chegando estes estudantes ao curso de psicologia?

A formação no curso de graduação em psicologia é plural porque o ser humano também o é. Existem diversas linhas teóricas e abordagens clínicas, distintos pressupostos e variados campos de atuação para o psicólogo. Sabe-se que na jornada de formação profissional do psicólogo haverá intensas horas de estudo teórico acerca do sofrimento psíquico, dos medos e angústias básicas, das principais teorias acerca da loucura e normalidade. Também é inevitável o contato pessoal com a dor, tristezas, medos, alegrias e superações de limites, próprios e daqueles que os procurarão.

A profissão demanda constantes aprimoramentos teóricos e técnicos, e também a busca por autoconhecimento, obtido muitas vezes com a realização de terapias individuais, supervisão, grupos de estudos e cursos de especialização e/ou formação.

Assim como se faz necessária uma formação universitária composta pelo domínio de variados arcabouços teóricos acerca de aspectos culturais, históricos, biológicos e psicológicos do ser humano, também é preciso que se considere a necessidade de elaborar e compreender a experiência que atravessa o estudante de Psicologia, situando-o como sujeito e objeto de seu próprio conhecer, visto que tal exercício dialético mostra-se como imprescindível para a formação profissional e pessoal.

A investigação acerca das possibilidades e potencialidades do manejo dos sonhos com a utilização de recursos verbais e expressivos dentro de grupo vivencial de sonhos é mobilizadora. O campo criado pelo grupo vivencial pode promover uma primeira compreensão e elaboração deste momento peculiar pelo qual os estudantes estão passando, a saber, uma experiência de iniciação vivida pelos recém-chegados estudantes ao curso de Psicologia.

Um dos pressupostos desta pesquisa é que a participação em um grupo vivencial de sonhos pode proporcionar uma experiência única ao estudante de psicologia, no que se refere 
ao modo como este olha para si próprio e toma-se como o sujeito e objeto de estudo, contemplando assim o aspecto de alteridade inerente ao trabalho do psicólogo. Tomar contato com esse tipo de compreensão e acolhimento pode ser muito válido e benéfico, pois permite simbolização e compreensão do próprio processo de entrada na faculdade, como também dos colegas, viabilizando uma apreensão da sua própria subjetividade enquanto indivíduo e enquanto profissional destinado a cuidar de outras subjetividades.

Levando em conta a possibilidade de se viver um desenvolvimento simbólico durante a participação em um determinado grupo, torna-se possível considerá-lo enquanto campo de transição e transformação. Por meio do trabalho com grupos vivenciais, é possível ir além do conteúdo a ser pesquisado e investir numa prática que favorece o crescimento pessoal, ao propiciar sustentação e acolhimento, construção de vínculos de confiança, confronto e reconhecimento da alteridade e possibilidade de movimentação entre as polaridades coletivoindividual. Valer-se de grupos vivenciais é interessante tanto nos contextos terapêuticos quanto nos contextos pedagógicos (Freitas, 2005).

O contexto grupal apresenta-se como um meio capaz de promover sustentação, acolhimento, confiança e respeito, requisitos necessários para que estudantes (psicólogos em formação) possam experimentar um processo inicial de autoconhecimento e elaboração de si mesmos e dos demais, como observadores e/ou facilitadores, permitindo uma aprendizagem profunda e pautada na experiência pessoal.

É relevante informar que inicialmente o objetivo desta pesquisa de mestrado consistia na realização de dois grupos vivenciais de sonhos: um grupo com estudantes recém-chegados e outro grupo com estudantes prestes a concluir o curso, o que acontece a partir do $5^{\circ}$ ano de estudo.

Assim, poderiam também ser cotejados, através dos sonhos compartilhados no contexto do grupo vivencial e do próprio movimento dos grupos, os símbolos emergentes nos momentos de entrada e saída do curso. Apesar de intensa divulgação, conversas e convites, infelizmente o grupo vivencial de sonhos com quintanistas não se realizou, porque apenas dois deles se interessaram.

Pesquisas como esta visam a proporcionar contribuições relacionadas à compreensão do modo como se dá a elaboração da experiência de entrada no curso de Psicologia e auxiliar aqueles que se dedicam a pensar e elaborar o currículo do curso de graduação em Psicologia. 


\section{EMBASAMENTO TEÓRICO}

\subsection{A DINÂMICA EGO E SELF}

A psicologia analítica de Carl Gustav Jung estrutura-se na consideração de que os dinamismos psíquicos são compensatórios e complementares e que o processo de desenvolvimento individual não segue uma linearidade lógica, mas perfaz um caminho cíclico e reincidente, sendo que as experiências passadas podem ser revisitadas e compreendidas por uma nova visão.

Jung identificou o inconsciente abrangendo um aspecto pessoal e outro coletivo. Diferentemente de Sigmund Freud, que entendia o inconsciente como um reservatório dos conteúdos pessoais reprimidos, ligados especialmente à infância, para Jung, o inconsciente continha não somente os aspectos reprimidos, "mas todo o material psíquico que subjaz ao limiar da consciência" (JUNG, 2015, p. 15).

O inconsciente pessoal é constituído por partes integrantes da personalidade de um indivíduo e pelas suas realizações, que podem ser conferidas quando se olha para seu histórico de vida. No inconsciente pessoal também está o que Jung chamou de sombra, aspectos individuais que não puderam, ainda, tornar-se conscientes.

O inconsciente coletivo contém, além das conquistas individuais, imagens históricas e primordiais, denominadas de arquétipos.

Os arquétipos são considerados como "caminhos virtuais herdados" (JUNG, 2015, p. 26) por conterem em si imagens comuns à humanidade, passíveis de serem atualizadas em cada época e em cada indivíduo. Alguns exemplos de arquétipos são as imagens da Grande Mãe, do Velho Sábio, da Criança, entre outras, renovadas de tempos em tempos.

O aparecimento de um arquétipo na vida de um indivíduo não se dá de forma direta e consciente, mas sim por uma constelação de fatores que remetem para a ativação do mesmo, uma vez que a sua força e intensidade é considerada numinosa e arrebatadora e assemelha-se à uma experiência religiosa:

Mesmo quando a consciência não o compreende, o arquétipo atua efetivamente. Ele fala em imagens que são comuns a todos os homens e jazem no fundo primário criativo de cada alma. Nelas, todo o individual é apenas mais uma parábola e passa a ser - como no mito uma reapresentação do universal e do eternamente humano (JACOBI, 1975, p. 114). 
Já a construção do ego se dá através da diferenciação do inconsciente, processo que se inicia na infância e estabelece-se ao longo da vida. O ego é considerado como o centro da consciência e seu papel é discriminar, discernir, avaliar e integrar, consolidando assim a noção de identidade individual.

Sendo assim, Jung compreendia que é necessário haver uma comunicação entre os conteúdos que se fazem conscientes e os conteúdos inconscientes para que o indivíduo possa se desenvolver e se direcionar para uma maior apreensão de sua realidade e seus conteúdos psíquicos. Esta comunicação é realizada através da função transcendente, responsável pela criação de símbolos, mobilizadores da energia psíquica.

Jung também notou a presença de figuras de relação do ego, como a persona, palavra cujo significado é máscara e coloca a necessidade de atuação e representação do ego em contextos específicos, nos quais se exige que diferentes funções e habilidades do ego sejam postas em prática.

Além da persona, há as figuras do Animus e da Anima, que tem a função de relacionarse com o sexo oposto e são acompanhadas de uma carga emocional proveniente da relação estabelecida com os pais. O Animus é considerado a parte masculina da mulher e a Anima é a parte feminina no homem. Ambos apresentam a possibilidade de um desenvolvimento interior e exterior que contemple a diferença em si.

Por meio do estudo dessas figuras, Jung notou que a psique é plural e assim como se faz necessário o estabelecimento e desenvolvimento de relacionamentos exteriores, também se faz importante o relacionamento interior, compreendendo a multiplicidade do ego, em suas múltiplas facetas e inúmeras possibilidades.

Para que se dê tal dinâmica relacional entre as múltiplas partes da psique é necessário que exista um processo de equilibração, ou autorregulação da psique, e este é percebido nos sonhos, visto a sua origem nos conteúdos inconscientes. Esse processo é capaz de compensar atitudes conscientes rígidas e unilaterais, indicando um novo caminho ou possibilidade para o ego.

Ao processo de desenvolvimento individual, considerando o relacionamento com a pluralidade da psique e a busca pela originalidade e plenitude do ser, Jung denominou Individuação, a qual significa "tornar-se um ser único, na medida em que por 'individualidade' entendermos nossa singularidade mais íntima, última e incomparável, 
significando também que nos tornamos o nosso próprio si-mesmo" (JUNG, 2015, p. 49, itálico do autor).

Este processo diz respeito ao desenvolvimento e amadurecimento psíquico, mas também se refere à transformação, desde que entendida como necessária para que cada indivíduo possa tornar-se autônomo, assuma suas potencialidades e possibilidades e vá se tornando cada vez mais singular e único.

De acordo com Hall, "individuação [...] refere-se ao processo em que uma pessoa na vida real tenta conscientemente e deliberadamente compreender e desenvolver as potencialidades individuais inatas de sua psique" (HALL, 2007, p. 25).

Porém, esta individualidade encontra-se intrincada na própria sociedade, uma vez que não se faz possível ser único, sem antes ser comum, não há como buscar a individualidade sem antes estar inserido na coletividade. Trata-se de um movimento contínuo, cíclico e dialético. É preciso que se invista no individual para que ele retorne e proporcione crescimento e desenvolvimento coletivo. Existem diversos exemplos na história da humanidade, em diferentes séculos, de homens e mulheres que ganharam expressão por sua individualidade, tonando-se verdadeiros ícones, e que, justamente, por devotarem-se a percorrer seu caminho individual provocaram efeitos disparadores de transformações coletivas.

Assim, por individuação não se entende a busca egoísta desenfreada, que sobrepuja-se às necessidades e valores da sociedade, mas à iniciativa de expressar-se, sentir, agir, ser quem se é, enquanto "combinação única, ou como uma diferenciação gradual de funções e faculdades que em si mesmas são universais" (JUNG, 2015, p. 50).

Para Whitmont, a relação entre indivíduo e sociedade, entre $e u$ e $t u$, é que possibilita um desenvolvimento a partir do self, ou seja, do Si-mesmo:

Na realidade, para o ego moderno, o self fala não só a partir do interior da pessoa, mas também de fora; além disso, o ego moderno é tanto psicológica quanto fisicamente dependente da comunidade da qual faz parte. É precisamente para estabelecer um novo e diferente ego, motivado pelo self, e em relação com o $t u$ e com o grupo, que são necessários rituais interpessoais e grupais apropriados (WHITMONT, 1991, p. 261).

Em seus estudos, Jung deparou-se com o arquétipo do self, ou do Si-mesmo, o qual costuma ser entendido pela consciência como um símbolo da totalidade, costumeiramente 
expresso pelo círculo ou mandala. O self está intimamente ligado ao processo de individuação, direcionando cada indivíduo para a busca de sua realização pessoal.

Sua presença se faz notar de diversas maneiras, em sonhos, em fantasias e em acontecimentos sincronísticos, ou seja, em acontecimentos externos que expressam e contextualizam uma transformação ou movimento interno. À primeira vista, os eventos sincrônicos causam estranhamento porque questionam a ordem lógica dos acontecimentos, como sonhar com uma pessoa e logo em seguida receber notícias da mesma, ou estar às voltas com determinado assunto e o mesmo mostrar-se em circunstâncias que nunca poderiam ser previstas.

Jung, ao observar tais manifestações do self, concluiu que:

[...] a meta do desenvolvimento psíquico é o Si-mesmo. A aproximação em direção a este último não é linear, mas circular, isto é, circum-ambulatória. Uma evolução unívoca existe quando muito no princípio; depois, tudo não é mais que referência ao centro (JUNG, 2016, p. 201).

Assim, ego e self, parceiros no caminho da individuação, nutrem-se um ao outro. 


\subsection{OS SONHOS E O SONHAR}

Cada sonho é um depoimento da alma sobre si mesma.

Jolande Jacobi, 1975

Existem muitas formas de apreender o fenômeno dos sonhos e da experiência do sonhar, e todas trazem importantes contribuições para ampliar o entendimento sobre o fenômeno onírico, tão fascinante e presente na experiência cotidiana.

Os sonhos mantêm um senso de realidade, já que as situações trazidas pelos sonhos muitas vezes comportam pessoas, objetos e acontecimentos reais, e, ao mesmo tempo, observa-se neles uma aparente falta de análise crítica e coerência lógica.

Um aspecto muito pertinente a ser explorado é que os sonhos revelam nossa criatividade e o nosso jeito de ser no mundo, sendo assim, "sonhar é um processo criativo" (KAST, 2010, p. 35).

Para Freitas, o sonho remete à capacidade criativa e integrativa do ser humano, utilizando-se então de outra linguagem com a finalidade de promover um outro tipo de compreensão:

Basta invocar um sonho para que se crie um clima com toques de poesia, de enredos talvez pouco prováveis, de associações soltas, agrupamentos e reagrupamentos de imagens visuais, ideias e emoções, sensações corporais. O sonho nos permite sair de algo linear, racional, previsível, cotidiano, promovendo uma ampliação de consciência (FREITAS, 2014, p. 80).

No texto Da essência dos Sonhos Jung declara que "o sonho é uma parcela da atividade psíquica involuntária, que possui, precisamente, suficiente consciência para ser reproduzida no estado de vigília” (JUNG, 2000, p. 224). Sendo assim, só é possível trabalhar com a memória e o relato dos sonhos, estando a consciência também envolvida. Caso contrário o sonhar seria uma experiência impossível de ser apreendida em sua totalidade.

É, portanto, natural que à primeira vista, as imagens oníricas, vindas de uma construção inconsciente pareçam não ter nexo nem relações entre si, porém uma análise mais atenta revela que é possível estabelecer ligações entre as imagens trazidas pelo sonho e os eventos cotidianos anteriores ao sonho, bem como o estado emocional do sonhador. 
Para Hall, "os sonhos estão a serviço da psique como um todo” (Hall, 2007, p. 127) pois nos conteúdos oníricos estão presentes fragmentos de acontecimentos vividos no estado de vigília, portanto, conscientemente. As vivências do sonho podem ter forte repercussão na consciência, por exemplo, alterando estados de humor ou trazendo à luz conflitos ocultos.

Em sua metodologia de interpretação do sonho, Jung realçava a importância da participação do próprio sonhador, uma vez que "precisamos da ajuda do sonhador para limitar a diversidade das significações verbais ao seu conteúdo essencial e convincente" (JUNG, 2000, p. 227).

Tratando-se de sonhos, toda interpretação é uma hipótese, assemelha-se a uma tentativa de ler um texto em língua desconhecida, no qual o sonhador desempenha um papel ativo, buscando relações e associações numa busca viva e significativa dos sentidos.

Assim, se duas pessoas sonham com o mesmo objeto, isso não significa que os dois sonhos terão a mesma interpretação, pois é preciso entender qual é o contexto, o sentido e as associações que o sonhador faz. Assim como a experiência, o sonho é único. Por isso, o sonho se configura como um símbolo, ou melhor, lembrar e trabalhar um sonho é uma experiência simbólica.

Por esse motivo é importante ressaltar a concepção de Jung de que "a princípio o sonho não tem significado algum e que vai adquirindo sentido à medida que for sendo analisado" (JUNG, 1986, p. 63). Pode-se comparar o conteúdo do sonho à matéria bruta que será lapidada, sendo as informações trazidas pelo sonhador as principais ferramentas.

Para Guggenbühl-Craig, "interpretar sonhos é uma atividade criativa, quase artística" (GUGGENBÜHL-CRAIG, 2008, p. 115). Sendo criativa, possibilita inúmeras versões, facilitando a elaboração simbólica e constituindo-se como matéria bruta ímpar.

Como o sentido na maior parte dos sonhos não coincide com as tendências da consciência, mas revela divergências bastante específicas, Jung admite que o inconsciente, matriz dos sonhos, apresenta um funcionamento independente, que se denomina "autonomia do inconsciente", visto que o fato de sonhar tem vida própria, é um processo automático e independente da nossa vontade e do controle da consciência (JUNG, 2000).

Hall ressalta que "os sonhos não são sonhados para serem analisados e compreendidos, mas uma compreensão deles nos diz onde o inconsciente já está tentando alterar a imagem do ego na direção da saúde e da individuação" (Hall, 2007, p. 36). Sendo assim, os coloca como parte natural e integrante da psique. 
Segundo Jung (2000), a experiência onírica, mesmo que enigmática e incompreensível, tem seu papel na autorregulação do organismo psíquico. É importante ter em mente que nem tudo precisa ser entendido de forma intelectual para exercer sua função sobre o psiquismo. Pensar em autorregulação é imaginar um fluxo recíproco entre o mundo consciente e o mundo inconsciente através do qual se realiza uma comunicação simbólica intensa e dinâmica, por exemplo.

A função compensatória dos sonhos se caracteriza por "uma confrontação e uma comparação entre diferentes dados ou diferentes pontos de vista, da qual resulta um equilíbrio ou uma retificação" (JUNG, 2000, p. 230). Desse modo, podemos perceber uma atitude compensatória quando o sonho mostra situações ou atitudes que se contrapõem àquelas usualmente mantidas ou vividas pelo sonhador e quando revela variações ou enfatiza suas tendências de comportamento e atuação, observando-se uma comunicação entre aspectos conscientes e inconscientes. Nisso consiste a experiência simbólica.

Assim, “o conteúdo essencial da ação onírica é uma espécie de compensação extremamente matizada de uma atitude unilateral errônea, desviada ou perturbada da consciência" (JUNG, 2000, p. 238). Um conteúdo compensador apresenta-se intenso quando tem importância vital para a orientação da consciência, e o inconsciente buscará levar à situação consciente do indivíduo tais elementos, caso eles não estejam podendo alcançar o limiar na consciência no estado de vigília.

No livro A Prática da Psicoterapia, Jung afirma que "a compensação pelo inconsciente só é eficaz quando coopera com uma consciência integral. A assimilação nunca é um isto ou aquilo, mas sempre um isto e aquilo" (JUNG, 1997, p. 27). Essa afirmação reforça que a consciência e o inconsciente são complementares e indissociáveis, embora às vezes a consciência os perceba em oposição.

No trabalho com sonhos, é fundamental considerar que se trata de uma comunicação, de uma ponte entre a consciência e o inconsciente, a qual pode estar mostrando caminhos possíveis ou mesmo procurando compensar aspectos rígidos que a consciência acabou assumindo. Quem desempenha esse papel de ponte é o símbolo. Para Jung:

O símbolo não é uma alegoria nem um semeion (sinal), mas a imagem de um conteúdo em sua maior parte transcendental ao consciente. É necessário descobrir que tais conteúdos são reais, são agentes com os quais um entendimento não só é possível, mas necessário (JUNG, 2013, p.101). 
Além da função compensatória, temos que atentar para a função transcendente, responsável pela formação dos símbolos em nossa psique. Para Jung, “o homem também produz símbolos, inconsciente e espontaneamente, na forma de sonhos" (JUNG, 2008, p. 21).

Portanto, na ocasião de um sonho, observamos que são formados símbolos oníricos, através dos quais se dá a o investimento de uma parcela de energia psíquica na imagem e no enredo do sonho. Através desses símbolos, os afetos são transferidos do inconsciente para a consciência, que tem, então, a possibilidade de retrabalhar tais afetos, possibilitando maior desenvolvimento e crescimento da personalidade (HARK, 2000).

Freitas, no capítulo Panorama dos Conceitos Junguianos (In: FREITAS; ALBERTINI, 2009), afirma que, para Jung, o símbolo, ao mesmo tempo que manifesta a psique, também a impulsiona, ao apresentar o novo à consciência, instigando-a a buscar uma consideração que pode envolver certo esforço na sua compreensão. Este processo de afloramento do símbolo seguido da sua tentativa de maior reconhecimento pela consciência traz a possibilidade de ampliação da mesma, visto que para assimilar algo novo é preciso também que algo se transforme em novo, criando assim, um potencial de transformação.

É importante frisar que "o símbolo, diferentemente dos conteúdos do inconsciente coletivo, é sempre histórico, contextualizado, apresentando-se numa dimensão de tempo, espaço e relação definidos" (FREITAS, 2009, p. 20).

Mas, em si próprios,

Os símbolos possuem pelo menos um sentido duplo: encobrem e revelam, ocultam e desvendam, são regressivos e progressivos, nos fazem lembrar e esboçam algo futuro. No símbolo encontramos reminiscência e antecipação, recordação e expectativa (KAST, 2010, p. 94).

Dessa forma, faz necessário abrir-se para o símbolo trazido pelo sonho, deixá-lo manifestar-se e vê-lo tomar forma. É preciso respeito aos conteúdos advindos em grande parte do inconsciente, que à primeira vista são complexos e novos, mas que já indicam tendências para o desenvolvimento da personalidade.

Os sonhos oferecem a possibilidade de experimentar aquilo que não nos permitimos na vida consciente. Aquilo que a consciência acaba por censurar, o inconsciente permite viver. Assim, os sonhos auxiliam a reconhecer intenções e disposições internas que impulsionam a elaborá-las e superá-las ou integrá-las à nossa vida. Os sonhos também nos permitem o 
contato com algo essencialmente desconhecido e novo à consciência. Deste modo, pode-se que dizer que os sonhos nos oferecem um ensaio, uma preparação à vida, propiciando-nos uma vivência simbólica.

É preciso tomar cuidado com as observações vindas de uma concepção teórica pois podem constituir uma tentativa arbitrária de interpretação (JUNG, 1986). Portanto, é de fundamental importância considerar as associações fornecidas pelo sonhador, que darão as diretrizes para a leitura do sonho e apreensão do seu sentido.

Para compreender o sentido de um sonho, Jung desenvolveu o procedimento de reconstituição de contexto, que nada mais é que uma etapa inicial da análise do sonho, na qual são mencionadas as relações entre o sonho e os conteúdos da consciência. Tal procedimento consiste em atentar para cada detalhe, significado e nuance que surja no sonhador no momento de suas associações.

Além disso, é preciso investigar as experiências precedentes do sonhador, como os acontecimentos do dia anterior, o estado de ânimo, planos e propósitos do sonhador nos dias ou semanas precedentes ao sonho. Obter um conhecimento do momento de vida e do caráter do sonhador também são importantes para uma análise mais profunda e particularizada.

Quanto ao trabalho de interpretação a ser feito com os sonhos, Jung (1997) indicou que ele pode ser de dois tipos: interpretação no nível do sujeito (analítica) e interpretação no nível do objeto (sintética ou construtiva).

$\mathrm{Na}$ interpretação analítica, o que aparece no sonho é identificado com objetos e situações da realidade de vida do sonhador. O método de trabalho consiste em decompor o conteúdo e os complexos que aparecem nos sonhos, relacionando-os com reminiscências cujas origens são de natureza externa ao sonhador.

Na interpretação sintética ou construtiva, ao contrário, entende-se o conteúdo que se manifesta no sonho como tendências ou partes do próprio sonhador, e o trabalho é atribuir e devolver ao sujeito cada um dos componentes do seu sonho.

Jung não optou por um único tipo de interpretação, mas afirmou que os dois seriam complementares e poderiam ser utilizados para a mesma imagem. Ele dizia que a origem de um objeto num sonho poderia ser determinada tanto objetiva quanto subjetivamente.

Detendo-se profundamente na análise dos sonhos, Jung apontou ainda outras possibilidades de abordá-los, tais como as perspectivas causal e finalista. Observados sob o 
ponto de vista causal, os conteúdos de um sonho são resultantes dos produtos psíquicos que o precederam. Porém, como todo fenômeno psicológico, devem ser abordados também no que diz respeito às suas finalidades, ou seja, a um “objetivo a alcançar”.

O ponto de vista causal tende, por sua própria natureza, para a uniformidade do sentido, isto é, para a fixação dos significados dos símbolos, concedendo um único significado, relacionado sobretudo a situações vividas. O ponto de vista teleológico ou finalista, vê nas variações das imagens oníricas a expressão de uma situação psicológica que se modificou e aponta para algo novo, não reconhecendo significados fixos dos símbolos. Assim, para se chegar a uma conclusão causal, o trabalho de elaboração é quase que exclusivo do terapeuta, que se torna uma espécie de detetive. Já na perspectiva finalista, o sentido e a elaboração são construídos quase que exclusivamente num trabalho conjunto com o sonhador.

Jung (1997) fala também da função prospectiva. Trata-se de uma antecipação surgida no inconsciente, uma espécie de exercício preparatório ou esboço preliminar. Seu conteúdo simbólico constitui, por vezes, o esboço de solução de um conflito. É uma espécie de combinação precoce de possibilidades que podem concordar, em determinados casos, com o curso real dos acontecimentos.

No texto A Função Transcendente, Jung afirma que o "inconsciente se comporta de maneira compensatória ou complementar em relação à consciência” (JUNG, 1967, p. 01). Tal afirmação justifica a necessidade da relação entre ambas instâncias para um bom funcionamento psíquico. Se a consciência se encontra em um estado unilateral, o inconsciente precisa agir para corrigir essa tendência e readaptá-la psicologicamente, sempre tendo em vista, que nenhuma adaptação é definitiva, uma vez que o par consciência-inconsciente é dinâmico e transforma-se ao longo da vida, sendo constantemente mediado pelas vivências simbólicas.

Quando longas séries de sonhos passam a ser analisadas, percebe-se que não é apenas a função compensatória que promove uma autorregulação entre a consciência e o inconsciente, mas também é possível perceber uma espécie de processo evolutivo da personalidade, no qual as ações compensadoras em cada sonho isolado se encaminham na direção de algo maior.

Assim, também é possível notar o papel dos sonhos no processo de individuação, pois:

A interpretação de um sonho permite que se preste um pouco de atenção consciente na direção em que o processo de individuação já está se desenrolando, embora inconscientemente. Quando bem- 
sucedida, tal associação de vontade consciente e dinamismo inconsciente promove e favorece o processo de individuação com mais rapidez do que é possível quando os sonhos ficam por examinar (Hall, 2007, p.33). 


\subsection{ESTRUTURA DRAMÁTICA ONÍRICA}

A partir de seu trabalho com os sonhos, Jung (2000) notou que é possível reconhecer uma certa estrutura nos sonhos análoga ao do drama.

Tal estrutura é composta de quatro fases: na primeira fase, denominada exposição, há a indicação de um lugar e segue-se a apresentação dos personagens e elementos que irão compor o sonho; na segunda fase, ocorre o desenvolvimento da ação, a situação vai se desenrolando e se estabelece uma tensão; a terceira é denominada culminação ou peripécia, ou seja, acontece algo decisivo, sendo que se configura um conflito, ou a situação muda completamente. Na última fase, lise, ocorre a solução ou o resultado produzido pelo trabalho do sonho.

Esta estrutura de análise facilita na identificação dos pontos nevrálgicos que pedem conscientização ou consideração, bem como os recursos que o sonhador tem à sua disposição para lidar com os mesmos.

Porém, vale lembrar que nem todo sonho apresenta essa quarta fase. Os pesadelos são sonhos sem lise, mobilizam intensa angústia e fazem com que o indivíduo desperte, assustado. Os pesadelos podem aparecer como uma resposta ou uma indicação para que se compreenda certa questão. Enquanto não for assimilada e vivenciada, ela tenderá a retornar. Quando o sonho se torna recorrente pode estar constituindo "uma tentativa de compensação para alguma dificuldade do sonhador em relação à vida" (WOLFF, 1981, p. 13).

O trabalho com os sonhos exige cautela e paciência, pois o simbolismo que deles emerge não pode ser tomado de forma rígida pelo pesquisador e/ou terapeuta. Esse material deve ser sempre cotejado com as impressões do próprio sonhador sobre o seu sonho, que inclusive pode se desdobrar em vários significados. É importante ter em mente que a linguagem do sonho é multifacetada. 


\subsection{OS SÍMBOLOS E A FUNÇÃO TRANSCENDENTE}

Por função transcendente podemos entender que se trata da comunicação, da relação de elementos conscientes e inconscientes, operada por intermédio da criação de símbolos. $\mathrm{O}$ objetivo final da função transcendente é transformar relações de polaridade entre consciência e inconsciente que ficaram por demais rígidas, promovendo uma maior fluidez e um movimento de transcendência do próprio ego, entendendo que este movimento se coloca como natural e necessário para o desenvolvimento humano.

A função transcendente é capaz de transformar, de colocar em movimento a energia psíquica disponível e canalizá-la num símbolo que possa ser útil e assimilado à consciência.

Sendo assim:

O símbolo aponta para além de si mesmo, indicando um significado que está fora do alcance das palavras conhecidas da nossa língua. A linguagem dos sonhos é arcaica: de modo espontâneo, à revelia de nossa percepção consciente, produz fragmentos de mitos, lendas e contos de fada, sob a forma de dramas pessoais. Estes estão vinculados às nossas relações e à nossa realidade mais profunda $\mathrm{e}$ podem nos pôr em contato com fontes e significados que nos permitem relacionar nossas vidas às nossas próprias estruturas míticas pessoais (WHITMONT, 1991, p. 23).

Para Jung (1967), um símbolo, como o trazido por um sonho, é sempre um produto de uma natureza altamente complexa, uma vez que ele se compõe de dados de todas as funções psíquicas. Ele tanto é de natureza racional quanto irracional. A carga de significado e experiência emocional que ele carrega afeta tanto o pensamento quanto o sentimento, a sensação e a intuição. 


\subsection{AS DUAS FORMAS DE PENSAMENTO E O ENCONTRO COM A ALQUIMIA}

Jung procurou demonstrar que "a intuição, a emoção e a capacidade de perceber e de criar por meio de símbolos são modos básicos de funcionamento humano, assim como a percepção através dos órgãos do sentido e através do pensamento" (WHITMONT, 1969, p. 17).

Para isso, Jung diferenciou duas formas de pensamento que operam e se alternam em nós: o pensamento dirigido e o pensamento-fantasia. O pensamento dirigido é um fenômeno que passa pela atuação da consciência, é identificado com a linguagem e necessita de concentração e atenção dirigida, não sendo considerado, do ponto de vista biológico, como natural, e sim fruto do esforço para acompanhar a realidade e com ela, se relacionar. É um pensamento que produz cansaço e, em alguns momentos, esgotamento, pois procura acompanhar a lógica e as relações de causa e efeito observadas na natureza. Além disso, está a serviço da cultura, é direcionado para a comunicação e entendimento dos nossos semelhantes.

Já o pensamento-fantasia tem afinidade pelo sonhar, é um fenômeno natural, espontâneo, que não requer esforço concentrado e flui, em movimento de ir e vir, do passado ao futuro sem uma ordem causal ou lógica. É nesta forma de pensamento que se encontram as forças criativas, oriundas do inconsciente, que produzem inúmeras fantasias.

Jung identificou neste pensamento um traço arcaico, que também se observa em crianças, nos povos da antiguidade e do qual se originaram os mitos da humanidade, levandonos a considerar que "a época que criou os mitos pensava da mesma forma como entre nós ainda hoje se faz o sonho" (JUNG, 2013, p. 45). Sendo assim:

Temos, portanto, duas formas de pensar: o pensar dirigido e o sonhar ou fantasiar. O primeiro trabalha com a comunicação, com elementos linguísticos, é trabalhoso e cansativo; o segundo trabalha sem esforço, por assim dizer espontaneamente, com conteúdo encontrados prontos, e é dirigido por motivos inconscientes. $\mathrm{O}$ primeiro produz aquisições novas, adaptação, imita a realidade e procura agir sobre ela. O último afasta-se da realidade, liberta tendências subjetivas e é improdutivo com relação à adaptação (JUNG, 2013, p. 39).

Humbert, (1985), no seu livro intitulado Jung, reconheceu três verbos que permearam e representaram o processo que Jung experimentou no decorrer de sua obra acadêmica e de sua vida e que o influenciaram na elaboração de sua compreensão a respeito do inconsciente. 
Estes verbos também definem a atividade da consciência para com os conteúdos inconscientes. São eles:

Geschehenlassen refere-se a deixar acontecer, ouvir os impulsos do inconsciente e deixá-lo se apresentar. Porém, não se trata de um mergulho cego, mas sim uma permissão deliberada para que ele se apresente.

Betrachten é traduzido como ponderar, engravidar e objetivar a emergência do inconsciente e considerá-la, realizar no sentido de despertar para a existência do outro. "Trata-se de deixar ao inconsciente o imprevisto e a força de suas manifestações e apesar disso não ser possuído por ele" (Humbert, 1985, p. 20). Porém, esse fazer só é possível através da objetivação da emoção, uma vez que esta permite um distanciamento saudável para o ego, que não se perde frente à emergência dos conteúdos inconscientes

Sich auseinandersetzen é confrontar-se com, compreender e ordenar racionalmente. "Em um tal confronto, o consciente coloca-se como sujeito e reconhece o inconsciente como "outro", isto é, como uma força autônoma que se exerce sobre ele e com a qual precisa entender-se" (Humbert, 1985, p. 22). É preciso um trabalho da consciência para nomear, perguntar, experimentar e, por fim, reconhecer o inconsciente.

Tais atitudes, experimentadas e desenvolvidas por Jung, formam a base da psicologia analítica, visto que a relação entre consciência e inconsciente é central no seu trabalho.

Durante a elaboração do Livro Vermelho, no qual entregou-se às fantasias do inconsciente, Jung deparou-se com a intensidade e força do pensamento-fantasia, necessitando buscar sustentação e apoio na sua família e em seu trabalho, entendendo-os como representantes da sua vida ordenada racional, que o relembravam da sua existência enquanto pai, marido, profissional e homem comum (JUNG, 2016, p. 195).

De acordo com Humbert, podemos dizer que Jung precisou mergulhar no inconsciente (deixar acontecer), observá-lo e de fato aceitar sua presença como um outro dentro de si (considerar) e depois registrar, passar a limpo e apreender a experiência (confrontar) podemos observar o movimento da função transcendente, o fluxo entre inconsciente e consciência guiando processo de individuação de Jung.

A incursão nesta experiência foi tomando uma proporção arquetípica, da qual precisou proteger-se e confrontar por meio do embasamento científico, situando a sua experiência pessoal como passível de ser compreendida e reconhecida. Percebeu, também, uma 
responsabilidade ética em relação às imagens provenientes do seu inconsciente, reconhecendo-as como autônomas.

Quando Jung iniciou seus estudos sobre a alquimia encontrou bases históricas para fundamentar e traduzir a transformação que vivenciava pessoalmente, formulando pressupostos científicos derivados de suas vivências íntimas, que, agora, encontravam ressonância na cultura.

Jung percebeu que os processos alquímicos se correlacionavam ao processo de individuação e: “[...] a sequência toda de operações alquímicas [...] bem poderia representar o processo de individuação de uma pessoa, levando-se, porém em conta que o simbolismo alquímico é mais rico e mais amplo que o do indivíduo tomado isoladamente" (EDINGER, 1984, p. 44).

Edinger descreve que o estudo da alquimia convida a adentrar um universo de imagens abundantes e sem a ordem lógica com a qual nosso pensamento está acostumado. Assim, procurou localizar as principais operações alquímicas e deteve-se no estudo de sete delas: calcinatio, solutio, coagulatio, sublimatio, mortificatio, separatio e coniunctio.

Cada uma das operações encerra uma questão específica e traz elementos que podem ser encontrados em diversas culturas. Segundo Edinger, é a calcinatio que inicia todo o processo, a qual associa-se o elemento fogo. A solutio é representante do elemento água; coagulatio corresponde ao elemento terra e sublimatio ao elemento ar.

Os alquimistas também consideravam a existência da prima materia, conceito derivado da filosofia antiga, que a entendia como a substância originária, a partir da qual tudo foi criado. A prima materia teria sofrido um processo de diferenciação, identificando-se quatro elementos: ar, fogo, terra e água. Também é possível relacionar tal diferenciação com a “criação do Ego, a partir do Inconsciente indiferenciado, através do processo de discriminação das quatro funções: pensamento, sentimento, sensação e intuição" (EDINGER, 1984, p. 49).

Jung buscou uma multiplicidade de linguagens que pudesse dar conta da experiência com o inconsciente, que é múltiplo, vasto e polifônico. Quando se procura desenvolver linguagens para facilitar a assimilação de conteúdos inconscientes na consciência, é possível que se opere uma transformação. Neste processo é preciso assegurar uma posição de distanciamento para o ego a fim de que a emoção possa ser observada e objetivada, minimizando-se os riscos de ser tomado por ela. 


\subsection{DIFERENTES LINGUAGENS}

A intensa valorização do aspecto racional da consciência ao longo dos séculos, contribuiu para que a emoção e a intuição ficassem relegadas a segundo plano nas prioridades do homem ocidental, e que a desenvoltura perante os afetos permanecesse atrofiada (WHITMONT, 1969).

O uso de recursos expressivos tem sido explorado e ampliado pelos grupos vivenciais como facilitador da elaboração simbólica do material e a sua assimilação na consciência. Os recursos expressivos podem trazer um trabalho artesanal e de cunho artístico, como pintura, escultura, confecção de máscaras; podem ainda ser relacionados a jogos dramáticos e também podem evocar o âmbito do cultural, quando se utiliza dos mitos e contos.

Pensando no caráter múltiplo e flexível dos sonhos, Mellick (2001) propõe que eles possam ser abordados de diversas maneiras, utilizando atividades artísticas, literárias, corporais, imaginativas, sendo assim acrescidos de uma leitura simbólica, que utiliza-se dos conteúdos oníricos para nutrir a imaginação e oferecer significado aos acontecimentos do dia. A autora sugere que os sonhos sejam vistos como imagens de outra realidade, com uma lógica e ética diversas em relação aos conteúdos conscientes.

A autora lembra que os sonhos utilizam uma estrutura narrativa que dispensa noções de causa e efeito, e anula leis físicas como tempo e espaço. Os sonhos também evidenciam facetas de nossa subjetividade, muitas vezes desconhecidas. A sabedoria de alguns sonhos pode equilibrar ou afirmar atitudes conscientes, mas nem sempre precisamos entendê-los para sermos beneficiados por eles. Ao contrário, a autora sugere que os abordemos através da circum-ambulação, do respeito à imagem onírica e sua própria cultura.

Mellick (2001) também sugere que o trabalho com sonhos permite à pessoa experimentar tanto uma abordagem com a qual ela tem familiaridade, quanto uma abordagem com a qual tenha mais dificuldade, o que pode nos ajudar a estabelecer uma percepção diferenciada do material onírico.

Freitas e Halpern-Chalom (2006), relataram o aspecto vivencial mobilizado em um curso de difusão cultural oferecido no Instituto de Psicologia da Universidade de São Paulo. O eixo norteador da pesquisa fora o processo de elaboração simbólica alcançado pelo uso de recursos facilitadores da elaboração simbólica, que podem ser culturais, como os contos e mitos que sintonizam um universo simbólico comum, ou podem ser individuais, como 
pinturas, esculturas, movimentos corporais, dramatizações ou textos, dentre outros. A utilização de recursos individuais e culturais de elaboração simbólica visava a favorecer o diálogo pessoal com os símbolos focalizados.

Para as autoras, além da elaboração do conteúdo simbólico, facilitada pelos recursos expressiva, é fundamental que se compartilhe o processo, para conferir autenticidade e reconhecimento da vivência individual (FREITAS; HALPERN-CHALOM, 2006).

Sendo assim, é preciso constantemente avaliar o papel dos coordenadores de um grupo vivencial, que precisam acompanhar os processos do grupo e também os próprios, atentando e acolhendo o imprevisto, o novo e o modo como interagem a cada encontro.

Assim como os mitos e contos, os sonhos também trazem a dimensão arquetípica para um plano de elaboração simbólica pessoal, entremeando o coletivo e o individual.

Em ambos os casos, há a possibilidade de serem compartilhadas realidades existenciais e humanas que, quando reconhecidas e acolhidas colaboram para o desenvolvimento da personalidade. Dessa forma, aproveitamos a consciência coletiva para favorecer a ampliação da consciência individual e vice-versa (FREITAS; HALPERNCHALOM, 2006).

Outra realização a respeito do trabalho com mitos no contexto grupal é mencionada no artigo A cabeça voraz:

Diante da massificação das culturas e a consequente perda de ritos significativos, cremos que o trabalho em grupo é imprescindível na tentativa de reversão desse processo. Jung já alertava para o perigo da unilateralidade do intelecto e enfatizava a importância da compreensão pela experiência, isto é, a vivência psíquica englobando as emoções e a totalidade das funções da consciência (FREITAS; AZEVEDO; VILHENA, 2000, p. 8).

Vale mencionar também a importância e influência que o Ateliê Aberto, iniciativa encampada pelo Laboratório de Estudos da Personalidade da Universidade de São Paulo LEP-USP na Clínica Escola do Instituto de Psicologia (CEIP) adquiriu nesta pesquisa de mestrado. Além de realizar pesquisas atreladas ao conhecimento e divulgação da psicologia analítica e realizar grupos vivenciais de dança circular para alunos, docentes e funcionários, o LEP, em parceria com o Serviço de Aconselhamento Psicológico criou o Ateliê Aberto, 
espaço destinado a promover um acolhimento inicial através da possibilidade de elaboração simbólica de conteúdos individuais trabalhados em grupo e valendo-se de atividades corporais, artísticas e expressivas.

A oportunidade de poder participar como pesquisadora de alguns encontros no Ateliê Aberto e inclusive propor uma atividade com os sonhos me proporcionou um embasamento e uma experiência muito importantes relacionada ao timing grupal e à atenção aos sinais e expressões corporais que indicam desconforto ou alívio emocional.

Iniciativas como o Ateliê Aberto podem ser cada vez mais valorizadas e ampliadas, visto que são capazes de promover duplamente o acolhimento demandado pela comunidade universitária e o ensino e a experiência para os próprios estudantes.

Assim, podemos perceber a importância de muitas linguagens auxiliares no processo de compreensão das fantasias e dos sonhos. Sem dúvida, este arcabouço auxiliou na elaboração de um plano de trabalho com o grupo vivencial de sonhos que contemplasse uma multiplicidade de recursos expressivos a fim de alcançar diferentes níveis de compreensão e de expressão individual e coletiva.

Whitmont também traz a dimensão do corpo na participação do ritual:

Ao nos vincularmos à atividade corporal, então, ligamos nossa consciência à dimensão mágica ativada da psique inconsciente. Isso significa que mobilizamos e canalizamos a energia do afeto primitivo e indiferenciado (potencialmente obsessivo) para uma forma. Simultaneamente, a percepção consciente se expande (WHITMONT, 1991, p. 266). 


\subsection{OS ARQUÉTIPOS DO MESTRE-APRENDIZ E DO CURADOR-FERIDO}

A compreensão e consideração do modo pelo qual o estudante ingressa no curso de psicologia é um dos objetivos desta pesquisa. Para isso, é importante buscar uma contextualização de como é vivido este momento, o que o integra e o que o torna tão único e especial.

Para a maioria dos estudantes, o ingresso na universidade corresponde a uma vivência de liberdade e autonomia, que inclui a conquista pessoal de passar no vestibular e ver consagrados os esforços e renúncias, tão próprios da época do Ensino Médio ou Cursinho.

Além disso, à conquista pessoal de passar no vestibular, soma-se, para muitos, o início de uma vida mais independente, ampliada ou não, pela necessidade da mudança de cidade para realizar o curso escolhido. Esta mudança, muitas vezes, traz em si a separação dos pais e familiares, além dos amigos, e por outro lado, acena com a possibilidade de uma primeira experiência de individualidade, de precisar "se virar sozinho" e conhecer novas situações e pessoas que trarão enriquecimento pessoal.

Também é vivenciada uma readaptação da rotina, dos pensamentos e comportamentos, surgem novas emoções, novos desejos e instaura-se um campo de possibilidades e descobertas. É um momento repleto de esperanças e inspirações. Mas também existem medos, dúvidas e ansiedades.

Este contexto específico, pode evocar a imagem de um ritual de passagem. Há um caminho novo a seguir e uma trajetória que foi importante, mas que precisa ser deixada para trás. Também se apresenta uma nova relação com o conhecimento, que se dá de maneira dialética e pessoalmente implicada, o que leva a crer que mobiliza os arquétipos do mestreaprendiz e do curador-ferido no estudante de psicologia.

Freitas (1995) relata sua experiência docente na disciplina optativa Psicologia Analítica e Arte Educacional, oferecida a partir do $4^{\circ}$ ano de graduação em psicologia na Universidade de São Paulo. Seu objetivo foi promover a vivência, a discussão e a elaboração teórica sobre os fundamentos da utilização de atividades expressivas na Psicologia Analítica.

Sua experiência revelou que, ao aluno de psicologia falta recuperar: "a palavra significativa, a palavra integradora do vivenciado, a palavra que permite a linguagem 
constituir-se num itinerário associativo e elaborador das situações experienciadas" (FREITAS, 1990, p. 98).

Esta palavra que reposiciona o aprendiz no centro de sua experiência é: "elemento indispensável, necessário, na constituição do campo interacional do arquétipo do mestreaprendiz" (FREITAS, 1990, p. 98).

A palavra que conecta, traduz e amplia é a propulsora do arquétipo do mestreaprendiz, que, à semelhança de uma roda, nos relembra que a cada instante da experiência vivida são necessárias novas e importantes questões, que possam reformular o vivido, pois o aprendizado e o conhecimento não são estáticos, mas se formam e de-formam constantemente.

E, para o psicólogo, afinado com a experiência e seu poder de mobilização, é imprescindível conhecer o potencial da palavra enquanto organizadora e transformadora do que se vive, uma vez que "a nível individual, a palavra expressa e exterioriza um processo de síntese, no qual intervêm todos os aspectos da personalidade" (FREITAS, 1990, p. 91).

Atualmente, é bastante questionável a qualidade da experiência com a qual nos deparamos e a presença de todos os aspectos da personalidade. $O$ incrível avanço da tecnologia favoreceu o contato com uma quantidade excepcional de informações, que chega até cada um de nós com intensidade e força, mas que parece não gerar assimilação e transformação. Tudo o que nos chega, também nos deixa, na mesma velocidade.

Larrosa Bondía procura definir a experiência como "o que nos passa, o que nos acontece, o que nos toca" (LARROSA-BONDÍA, 2002, p. 21) porém ela está cada vez mais afastada, talvez devido à intensa quantidade de informações e opiniões e fatos que nos invade, ou por estarmos insensíveis diante dela. Também questiona o processo educacional e o lugar e tempo necessários para que se dê uma verdadeira experiência:

Cada vez estamos mais tempo na escola (e a universidade e os cursos de formação de professorado são parte da escola), mas cada vez temos menos tempo. [...] e na escola o currículo se organiza em pacotes cada vez mais numerosos e cada vez mais curtos. Com isso, também em educação estamos sempre acelerados e nada nos acontece (LARROSA-BONDÍA, 2002, p. 23). 
Esta organização do ensino, exposta acima por Larrosa Bondía, inibe o aprofundamento que a consciência precisa para que se dê um aprendizado enraizado e incorporado. Whitmont avalia que "a experiência mediada pela participação corporal assinala a diferença entre ter a informação de alguma coisa e conhecê-la por experiência própria" (WHITMONT, 1991, p. 266).

Esta discussão aqui pretendida encontra paralelos no artigo A formação de psicólogos: um serviço a serviço de alunos:

O que é aprender se não 'dar sentido' a uma observação, a um conceito, a uma vivência? Aprendizagem significativa porque modifica aprendiz e conceito, porque se manifesta como forma de integração do mundo interno e do mundo externo. Porque faz do aluno participante de sua aprendizagem, permite que este se situe, apropriese, signifique, conquiste, amplie (CARVALHO; BACCHI; KOVÁCS, 1997, p. 239).

É importante indagar quais são os fatores necessários para se facilitar esta experiência, esta aprendizagem significativa, que envolve o corpo e a totalidade da personalidade. Mais ainda, é importante compreender como esta experiência pode afetar, especificamente, os estudantes ingressantes no curso de psicologia de uma universidade estadual pública.

Talvez, uma resposta possa ser esboçada ao se pensar nos rituais e na contenção e atualização que proporcionam. 


\title{
2.8 OS RITUAIS PSICOLÓGICOS
}

Existem momentos de transição bastante importantes ao longo das fases de desenvolvimento humano. Estes momentos, em geral, enfatizam a necessidade de se romper com um estágio anterior para que se possa avançar para o próximo. Tais rupturas geralmente são sentidas como solitárias e dolorosas, porém, pelo fato de nos encontrarmos inseridos em uma coletividade, sabe-se que mais cedo, ou mais tarde, chegará o mesmo momento para nosso semelhante.

Nas culturas primitivas, os rituais realizavam esta passagem, promovendo uma legitimação cultural do que se passava em um nível individual. Fazia-se necessária a intervenção cultural justamente para modular e canalizar as emoções associadas aos momentos de transição:

\begin{abstract}
Nas sociedades tribais é o rito de iniciação que resolve de maneira mais eficiente esse problema. O ritual faz o jovem retornar às camadas mais profundas da identidade original existente entre a mãe e a criança ou entre o ego e o self forçando-o, assim, a conhecer a experiência de uma morte simbólica. [...] é salvo solenemente desse estado pelo rito de um novo nascimento, o primeiro ato de verdadeira assimilação do ego em um grupo maior, esteja ele sobre a forma de totem, clã ou tribo ou uma combinação dos três (HENDERSON, 2008, p. 169).
\end{abstract}

Outro aspecto importante é que "através do ritual, a energia ganha corpo e é efetivada a passagem de um estado para outro" (WHITMONT, 1991, p. 258), indicando a necessidade da carga emocional para se fazer a passagem.

"O ritual [...] insiste sempre nesse rito de morte e renascimento, isto é, um "rito de passagem" de uma fase da vida para outra, seja durante o amadurecimento da infância ou do início para o final da adolescência e daí para a maturidade (HENDERSON, 2008, p. 170).

Assim, "a ritualização visa a execução consciente de impulsos arquetípicos ou emocionais, por meios social e pessoalmente aceitáveis, que, pelo menos de forma simbólica, expressam a intenção dessas ânsias” (WHITMONT, 1991, p. 43). Dessa forma, os afetos individuais encontravam continência na coletividade. 
Viver uma experiência por completo e ser transformado por ela é encontrar um significado, um sentido capaz de reorganizar e reestruturar a personalidade. Da mesma forma, acontece com o ritual: "ele precisa ser vivido como significativo. Quando esse senso de significado está ausente, o ritual não fala à consciência e, então, não consegue efetuar a transformação" (WHITMONT, 1991, p. 260).

Sabe-se que em muitas tribos indígenas, no momento em que a criança se mostrava apta a adentrar o mundo adulto, os rituais de passagem davam conta desta experiência. Geralmente, incluíam provações que envolviam determinação, coragem, disposição para a luta e espírito aventureiro.

Talvez, para muitos adolescentes, a entrada na faculdade represente este momento em que precisam provar - para a sociedade e para si próprios - que possuem coragem, garra e dão conta de se sustentar, materialmente e emocionalmente.

E, no contexto específico da entrada na faculdade de psicologia, mais cedo ou mais tarde, os estudantes se deparam com as suas próprias dores, medos, dúvidas e feridas internas, adentrando assim, o campo constelado pelo arquétipo do curador-ferido.

A Psicologia, é uma ciência múltipla, recebe contribuições das áreas biológicas e humanas. É comprometida com o estudo e a produção de conhecimento acerca dos fatores promotores de saúde e do adoecimento psíquico, da construção da personalidade, dos processos de aprendizagem, do funcionamento do comportamento, além de muitos outros, e também envolve a dimensão do cuidar, de promover e compartilhar uma experiência emocional profunda e presenciar a possibilidade de transformação pessoal.

No artigo A formação de psicólogos: um serviço a serviço de alunos, são levantados dois motivos principais para a escolha do curso de psicologia. O primeiro refere-se à busca de autoconhecimento, podendo incluir a necessidade de ajuda emocional. O segundo relaciona-se à vontade de "ajudar” os outros (CARVALHO; BACCHI; KOVÁCS, 1997).

Assim, estão mencionadas as tentativas de procurar a cura para si ou promovê-la para os demais. De certo, a cura e a ferida, a saúde e a doença são aspectos indissociáveis e fazer deles sua profissão exige a atenção para o cuidado consigo e com o próximo. Mobiliza-se então o arquétipo do curador-ferido que traz, em si, a possibilidade de vivenciar a doença e a cura de forma dialética e complementar. 
Sendo assim:

O objetivo do terapeuta é mobilizar o aspecto curador no paciente, despertando-o e chamando-o a colaborar com o processo. Isto somente é possível se o contato entre seus próprios aspectos "curador" e "ferido" for vivo e de colaboração (FREITAS, 2009, p.27).

Kovács (1985), realizou um estudo acerca do medo da morte no universitário de primeiro ano da área de saúde, medicina, enfermagem e psicologia e também avaliou o modo pelo qual o jovem se posiciona frente ao medo da morte, justamente no momento em que se encontram em pleno desenvolvimento seus planos, entendendo que "pode ser que seja justamente neste momento, em que há um maior envolvimento com a vida em busca de realizações tão almejadas, que a morte pode surgir como um fantasma, que pode interromper todos estes planos" (KOVACS, 1985, p. 48).

Nos resultados, o grupo de psicologia apresentou escores mais altos do medo da morte, o que fez levantar a hipótese de que este público esteja acostumado a expressar seus sentimentos sem constrangimento, e que também busquem maior autoconhecimento, e neste processo, sintam a angústia em si e nos demais. Sendo assim, a autora sinaliza a necessidade de expressão de sentimentos, através de recursos como role-playing, discussões de caso, seminários, trocas de experiências, atentando para a necessidade de novos procedimentos de ensino e da re-estruturação dos componentes curriculares do curso (KOVACS, 1985).

Para a autora:

Estes procedimentos de ensino ofereceriam uma sensibilização ao tema, facilitando uma abordagem mais humanista frente ao indivíduo angustiado diante da perspectiva de sua morte, quer concreta quer simbólica, mas nem por isto menos temida (KOVACS, 1985, p. 122).

O contato com o sofrimento psíquico, seja através da vivência de morte, angústias e medos em algum momento do curso será estabelecido e assim, espaços para discussão desta experiência enquanto aluno e futuro profissional podem ser muito produtivo pois "há pouco investimento no desenvolvimento e engajamento pessoal do aluno [...]. Enfatiza-se o conteúdo, a informação, à medida que há uma predominância de aulas teóricas e expositivas, não existindo quase espaços onde o aluno possa se 'ver"'. (CARVALHO; BACCHI; KOVÁCS, 1997, p.236). 
Além da falta de um espaço propício para o compartilhamento de experiências pessoais sobre o próprio curso, outro perigo que ronda o estudante de psicologia é a identificação com uma persona fixada e estereotipada, não criativa, do psicólogo, que se refere ao papel e função do psicólogo na sociedade e o que se exige dele em termos de comportamento esperado. Ao identificar-se com a persona do profissional que tudo sabe, corre o risco de atrelar conceitos e teorias à própria personalidade e relações pessoais, satirizada pela tirinha abaixo, criada pelo quadrinista Liniers ${ }^{3}$ :

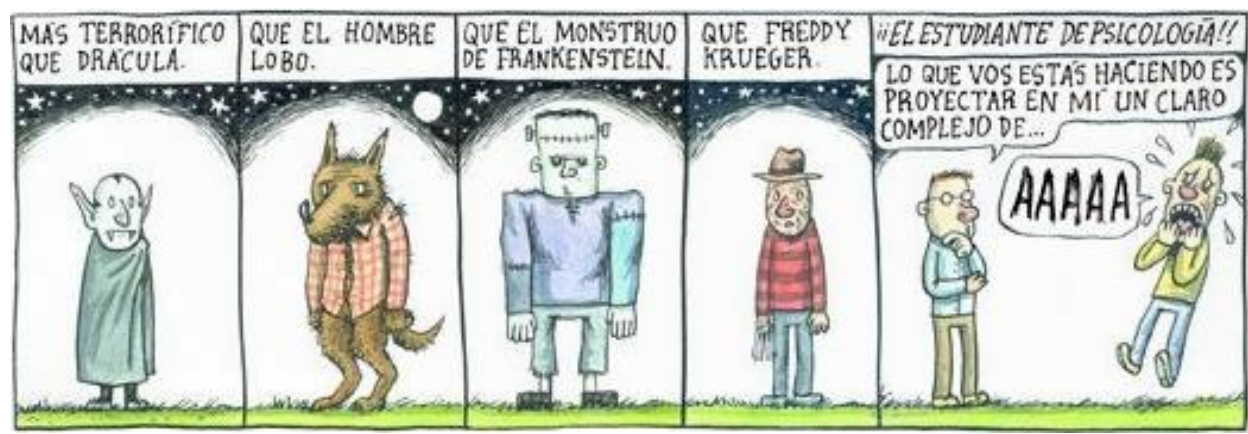

3 Esta tirinha faz parte da série Macanudo. As tirinhas são publicadas no jornal Lá Nación, de Buenos Aires, desde 2002. Esta tirinha encontra-se disponível em: https://meandros.wordpress.com/2007/05/26/macanudo/. Acesso em 02/02/17. 


\subsection{GRUPOS PARA JUNG}

Carl G. Jung produziu poucos escritos acerca dos grupos e fenômenos grupais. Percebe-se em seus escritos uma grande ressalva em relação a um nivelamento e a uma certa homogeneização que os grupos poderiam promover, deixando de ser grupo e tornando-se massa, a qual não preserva a autonomia e individualidade de seus integrantes e os leva a um nível de consciência estagnado.

Em seu texto, Sobre o Renascimento (2002), Jung aponta diversos aspectos relativos ao conceito de renascimento e procura expor seus principais significados, abordando também possíveis aspectos psicológicos que subjazem a tal conceito. Primeiramente, expõe que o renascimento não é um processo apreensível através da observação, pois tem seu potencial enquanto realidade psicológica. Sendo assim: “não podemos medi-lo, pesar ou fotografá-lo; ele escapa totalmente aos nossos sentidos. Lidamos aqui com uma realidade puramente psíquica, que só nos é transmitida indiretamente através de relatos” (p. 121).

O renascimento é experimentado em cada psiquismo individual, porém é de natureza arquetípica, visto que o tema do renascimento é compartilhado nas mais diversas culturas e em diferentes períodos da história humana. Dentre as diversas transformações provocadas pelo processo de renascimento estão as de caráter subjetivo, na qual se dá uma transformação da personalidade.

Jung denominou identificação com um grupo o processo de renascimento que se trata da "identificação de um indivíduo com um certo número de pessoas que têm uma vivência de transformação coletiva" (JUNG, 2002, p. 130). Também consente que há mudança na vivência coletiva, mas esta parece não ter o mesmo impacto e duração de uma mudança ocasionada por vivência individual, uma vez que é preciso a presença constante do grupo para validar a transformação e alimentar a uma identificação inconsciente do indivíduo com o grupo em questão.

Ao ser instituído um ritual no grupo, a "inevitável regressão psicológica dentro do grupo" (JUNG, 2001, p. 131) pode ser contida, levando-se em conta que para o ritual acontecer há a necessidade de atenção e presença consciente de cada um dos envolvidos, protegendo-os assim de cair em uma inconsciência prejudicial e animal. 
Certamente, é preciso levar em conta a época de publicação do texto, pois o contexto histórico e político do momento alertava para a grande periculosidade das massas, visto as recentes relações entre massa nazismo e comunismo.

A grande questão que Jung coloca para o trabalho em grupo é que o mesmo possui uma grande atração para a despersonalização e inconsciência do indivíduo uma vez que o grupo poderia então ser considerado correlato ao inconsciente coletivo, que do âmago da psique ronda e ameaça o ego, o qual precisa trabalhar arduamente para conquistar individualidade e autonomia, as quais podem, de uma hora para outra, serem questionadas e transformadas, a partir de eventuais fatores externos e o domínio do ego precisará ser reconstruído

Assim, se, para Jung, o grupo pode representar o perigo do rebaixamento a uma consciência inferior, por outro pode-se pensar que é justamente por apresentar essa ameaça que poderia se constituir enquanto antídoto para o mesmo, na medida em que poderia impulsionar o indivíduo para que se faça enquanto tal, a partir de sua experiência no grupo.

Assim, apesar de ter escrito pouco sobre grupos, nos conceitos de individuação e inconsciente coletivo, é inerente a presença do individual e também do coletivo. Ao inconsciente pessoal, formado por conteúdos reprimidos e esquecidos, Jung acrescentou o inconsciente coletivo, fonte criativa da psique e matriz comum de todos os seres humanos, em função do passado ancestral que compartilhamos. Além disso, Jung deu especial importância em sua teoria ao processo de individuação, que explica como uma realização individual e assimilação à consciência daqueles aspectos inconscientes, arquetípicos, comuns a todos os homens. 


\subsubsection{GRUPOS VIVENCIAIS NA PSICOLOGIA ANALÍTICA}

Freitas (2009) ao comentar sobre as publicações de Jung que abordam os trabalhos psicológicos em grupo nos oferece uma alternativa de intervenção profissional que, por considerar as especificidades do contexto grupal, é capaz de situar o potencial de participação no grupo em um dado momento da vida individual:

Um grupo costuma ter uma identidade menos estabelecida ou duradoura, geralmente tem começo, meio e fim inseridos na duração da vida dos indivíduos e articulado à pertinência a outros grupos. Isso lhe confere um aspecto de transitoriedade e de algo efêmero, mas não lhe subtrai a possibilidade de criar imagens e tanto mover-se a partir delas ou em busca delas quanto defender-se delas, além de constituir uma história, ou seja, viver um desenvolvimento simbólico (FREITAS, 2009, p. 82).

No texto Processo de "Grupação"? - Reflexões sobre o Potencial dos Grupos Vivenciais, Freitas (2006) narra sua experiência na coordenação de grupos de construção de máscaras e comenta o potencial de elaboração simbólica que é viabilizado no contexto de um grupo vivencial.

A autora desenvolveu uma prática de trabalho com grupos vivenciais em que os integrantes se reúnem numa série de encontros e constroem máscaras e personagens com o objetivo principal de explorar o potencial criativo de cada um e também poder vivenciar a experiência em grupo, contemplando assim aspectos individuais e coletivos. Com a finalidade de oferecer diferentes linguagens a partir das quais fosse facilitada a expressão individual e simbólica, a autora buscou recursos expressivos corporais, plásticos e dramáticos.

O referido trabalho contou com três etapas: na primeira, houve a confecção artesanal de máscaras; na segunda deu-se o estabelecimento de uma etapa dramática, na qual ocorreu a utilização das máscaras criadas e a apresentação das mesmas ao grupo, e finalmente uma etapa de elaboração verbal da experiência vivida. Durante as três etapas, o grupo, assim como cada participante, foi experimentando um processo de definição, a partir do compartilhamento do tempo, da atividade, das experiências, de forma que foi possível à autora observar que: 
O trabalho com grupos vivenciais consiste na criação de um campo interacional específico, no qual se relacionam forças dinâmicas que põem em contato todos os participantes e, simultaneamente, encarregam-se do estabelecimento de uma coesão tal que torna-se possível falar numa consciência grupal, numa sombra grupal e em símbolos grupais (FREITAS, 2005b, p. 58).

No decorrer do grupo vivencial dá-se o confronto com diferentes pensamentos, experiências e realidades, o que é muito importante para que se vivencie a experiência de transitar entre as polaridades coletiva e individual. Participar de um grupo, entrar e permanecer em contato com outras pessoas, possibilita a emergência de um processo de desenvolvimento que, em analogia ao processo de individuação, pode ser denominado de processo de "grupação" (FREITAS, 2006).

A "grupação" refere-se a um desenvolvimento que se dá na situação grupal, tanto em relação ao grupo quanto aos participantes individualmente. Esta perspectiva é interessante, uma vez que de fato o indivíduo se desenvolve e caminha em processo de individuação em contextos grupais, no seio de uma família e de uma comunidade específica, espaços coletivos marcados por peculiaridades sóciohistóricas e culturais, que também promovem o desenvolvimento da consciência coletiva.

O grupo define uma totalidade que Freitas (2005) denominou de self grupal, ao ampliar o conceito junguiano de self individual. Jung denominou self ao centro autorregulador da psique, que age autonomamente, no inconsciente, impulsionando o desenvolvimento humano, através do processo de individuação. Para Jung, o self também é o arquétipo da totalidade, denominado si-mesmo, e engloba aspectos tanto conscientes quanto inconscientes da psique, considerados complementares. O self refere-se, portanto, ao centro e ao todo.

Com o estabelecimento de um campo interacional no grupo vivencial dá-se a construção de um "self grupal” que se manifesta por meio dos símbolos, questões, tensões e temas compartilhados. E, no "self grupal" a alteridade pode existir e se expressar pela interação das individualidades de cada membro, que cria um campo dinâmico e específico, em constante movimento.

Além disso,

Nos grupos vivenciais assim concebidos, há um cuidado deliberado com as condições contratuais relativas à duração do processo do grupo e de cada encontro, ao compromisso de sigilo necessário e assumido por todos, ao clima de acolhimento e respeito pelo que é trazido e expresso; e uma atenção também às condições de comunicação e 
interação, pautadas em busca de clareza, expressão a partir de si próprio, cada um se responsabilizando por si mesmo, e a manutenção de relações simétricas, embora não de igualdade (FREITAS. In: FARIA; FREITAS; GALLBACH, 2014, p. 94).

Em relação ao papel do coordenador do grupo, a autora comenta que coordenar um grupo vivencial implica em trabalhar para estabelecer e manter um campo interacional no qual os símbolos possam se definir, apresentar, interagir e ser assimilados de alguma forma à consciência.

Assim, nos traz a imagem da deusa grega Héstia, que cuida de que o campo interacional possa ser constelado. A deusa é representada por um círculo ou uma chama que enfatiza a interioridade, o acolhimento, a focalização, o calor e um clima emocional de fraternidade.

Este aspecto é fundamental para qualquer trabalho que se proponha a revelar aspectos e conteúdos inconscientes, de caráter íntimo, uma vez que a possibilidade de acolhimento, respeito e confiança, evita o desconforto e constrangimento excessivos. E apenas quando o simbolismo caracterizado por Héstia vem integrar um grupo vivencial há a possibilidade de uma experiência psicológica acontecer (FREITAS, 2005b).

Freitas (1987) também pontua a importância de o coordenador colocar-se à disposição para uma conversa individual durante a realização do grupo, promovendo assim um primeiro pilar de confiança e sustentação para a mobilização que virá.

Segundo Gallbach, "o estudo e a elaboração de sonhos num contexto grupal proporcionam um número maior de experiências por parte dos participantes, tanto como sujeitos quanto como observadores de vários processos oníricos" (GALLBACH, 2000, p. 16).

Gallbach (2000) relata sua experiência no trabalho com os sonhos no livro Aprendendo com os sonhos. Neste livro, a autora descreve a organização das atividades de seus grupos de sonhos, que basicamente ocorre em quatro fases. Na primeira se dá o relato do sonhador sobre o seu sonho para o grupo, é escolhido um título que nomeia o problema, o tema central. Isso já se configura como uma primeira elaboração, uma vez que o sonho é contado em voz alta e no tempo presente. A segunda fase é uma instrução sobre o exercício de Imaginação Corpo Ativa (ICA), criado pela autora, em que o participante procura reconstituir seu sonho e suas emoções em um estado de relaxamento, de maneira individual. A terceira fase é o relato da experiência com o exercício, os comentários, observações, associações, 
enfim, inicia-se um trabalho de reflexão conjunta. A quarta e última etapa é a elaboração final sobre a experiência, incluindo as observações, comentários e amplificações da colaboradora e do grupo.

A autora também ressalta a importância de alternar uma observação próxima e outra distanciada, e usar as quatro funções identificadas por Jung - pensamento, sensação, sentimento e intuição - de modo a trazer equilíbrio para o trabalho. A autora faz uma exposição bem ampla, que permite também identificar os complexos envolvidos nos sonhos e observá-los à distância, a fim de se compreender a atitude predominante e facilitar uma nova postura.

A Imaginação Corpo-Ativa é precedida por um relaxamento a fim de sensibilizar a pessoa para a realidade corporal e visa a aproximar o conteúdo onírico da vivência sensível, favorecendo o contato emocional com os conteúdos dos sonhos. O primeiro exercício, Imaginação Corpo-Ativa com os principais elementos do sonho, focaliza o que Jung denomina de fase de exposição, ou seja, cenário, personagens e dinâmica, e o sonhador, por meio desta técnica, observa e interage com esses três aspectos.

Inicia-se, então, a Imaginação Corpo-Ativa com os personagens do sonho e pede-se para que a pessoa volte ao sonho e vivencie as personagens, adotando sua postura corporal e conscientizando-se da sensação corporal ao vivenciar essa mesma postura. Segue-se a Imaginação Corpo-Ativa com os espaços e então com os movimentos do sonho.

Desse modo, na Imaginação Corpo-Ativa, ao invés de pensar sobre as personagens, o sonhador vai se transformar nelas, estabelecer uma empatia profunda e assim perceber o que projeta inconscientemente nelas. Assim, o sonhador entra em contato com seus aspectos sombrios, aproximando polaridades dissociadas. Fazer um relaxamento e, a partir do mesmo conscientizar-se da sensação corporal dos vários elementos do sonho, ajuda a perceber posturas corporais projetadas, bem como observar a ligação de complexos psíquicos com posturas e sensações corporais (GALLBACH, 2000, p. 157).

Outra iniciativa relacionada aos grupos de sonhos vem de Lawrence (2010), o qual, partindo do referencial psicanalítico, utiliza-se de técnicas de diversas abordagens, incluindo a junguiana, para explorar o campo de trabalho com grupo de sonhos em outros contextos, como o empresarial.

O autor cunhou o conceito de "sonho social", que se trata em linhas gerais, de uma técnica de abordagem de sonhos em grupo, enfatizando a atmosfera sociocultural da qual os 
participantes são provenientes. Utilizando-se associações livres, amplificações e pensamento sistêmico, busca clarificar a relação social estabelecida no grupo, "pré-sentidos" captados pelos membros individualmente, mas com potencial de contribuir para a identificação de dificuldades grupais, potenciais criativos e cultura institucional. $\mathrm{O}$ indivíduo não assume o sonho individualmente e, sim, o conteúdo individual é trabalhado em conjunto com vários outros conteúdos individuais, mas dirigidos ao interesse social, do grupo.

O trabalho com grupos vivenciais tem se mostrado de grande valia quando se trata de desenvolver aspectos tais como a descoberta e aceitação da alteridade, o oferecimento e recebimento de suporte emocional e, sobretudo, o desenvolvimento de vínculos de confiança e respeito. A estrutura dos grupos vivenciais abre possibilidades para o surgimento e manutenção de intimidade e confiança entre os integrantes do grupo.

O trabalho de Freitas (2005, 2005b e 2006) contribuiu indicando a necessidade de garantirmos um ambiente de acolhimento, um clima de intimidade e confiança e um ritual, na forma de roteiro, que, embora claro, não precisa ser rigidamente seguido.

As atividades propostas devem considerar estes aspectos. A expressão dos sonhos exige uma disposição de todos para se expressarem com abertura e confiança e também respeitarem o relato e as contribuições dos outros participantes, garantindo, mais do que um sigilo, a valorização do que acontece entre eles; os coordenadores são aqueles que devem sustentar um ambiente propício à emergência do self grupal, bem como um ambiente para o qual todos retornem durante o andamento da atividade.

Segundo Gallbach:

\begin{abstract}
Muitas vezes é mais fácil abordar um conteúdo emocional turbulento num grupo - pela confiança na colaboração e suporte dos outros - do que num enquadre de análise individual. Um grupo pode constituir um espaço ou vaso alquímico para a elaboração e transformação dos conteúdos oníricos (GALLBACH, 2000, p. 40).
\end{abstract}

Parisi, (2009) realizou um estudo sobre o processo de individuação que tomou curso em um grupo de mulheres que possuíam em comum a experiência de separação amorosa. A autora notou também que o objetivo terapêutico vivencial acontecia simultaneamente à coleta de depoimentos nos encontros do grupo, o que acarretava modificações constantes nas participantes e na coordenação a cada encontro, pedindo uma apreensão intuitiva no momento 
do grupo e uma organização posterior dos dados, permitindo uma articulação com as teorias que embasaram a sua tese de doutorado, a qual foi transformada em livro.

A utilização do trabalho com a imaginação e o manuseio de materiais como pintura, desenho e argila, além do recurso a contos e mitos permitiram a entrada no campo simbólico e também a criação de "temenos", o espaço sagrado delimitado onde ocorre a transformação. Parisi diz:

\begin{abstract}
Neste trabalho pude constatar que o grupo vivencial pode ser bastante eficaz para promover a ampliação de consciência; possibilitou à participantes uma maior percepção de si próprias através do encontro das diversidades e das atividades desenvolvidas (PARISI, 2009, p. 247).
\end{abstract}

Dessa forma, pode-se entender que o contexto grupal traz a possibilidade de se favorecer a individuação, por meio da "grupação", ao considerar as individualidades, permitindo que se possa emergir novas direções e sentidos que influenciem e desenvolvam o restante do grupo, num movimento de ações e assimilações contínuas.

Além disso, percebe-se que as dimensões individual e grupal estão sempre se entrelaçando, se envolvendo e se des-envolvendo, se enrolando e se des-enrolando, de uma maneira absolutamente imprevista e criativa (FREITAS, 1987).

A partir do embate com a diferença e do oferecimento de continência para com o imprevisível, abre-se espaço para o novo, que pode agir como elemento transformador, desencadeado pelo grupo vivencial.

De acordo com Freitas, quando se busca novos contextos que favoreçam a individuação, os grupos vivenciais, com a utilização de recursos expressivos se destacam. Isso acontece porque a pluralidade e a grande mobilidade psíquica podem ser reconhecidas e acompanhadas, em alguma medida, num contexto que força o reconhecimento e a construção de maneiras de interação com o diferente (FREITAS, 1987). 


\subsection{CONTRIBUIÇÕES DO PSICODRAMA}

Quando Whitmont contextualiza o ritual, aproxima-o do jogo dramático: "fundamentalmente, o ritual é um psicodrama, é um jogo dramático consciente e fervoroso" (WHITMONT, 1991, p. 263).

Sendo assim, faz-se importante buscar conexões com o psicodrama e relatar algumas de suas contribuições no entendimento do papel desempenhado pela ritualização.

Jacob Levy Moreno foi o criador do psicodrama, o qual traz em si potencial investigativo e transformador, que permite abrigar e envolver o que for relevante no momento para seus participantes. Assim, propicia um verdadeiro encontro com a emoção e seus efeitos, que podem ser mobilizadores.

Para que a transformação possa operar, é preciso que se cuide para que o grupo se constitua permitindo confiança, respeito e liberdade. Neste sentido, o contrato grupal assume uma grande importância, pois contribui para definir o grupo e "autoriza a todos que participem do grupo, com equidade, ou seja, com oportunidades iguais, dentro das diferenças individuais" (RODRIGUES, 2016, p. 54).

É a partir do estabelecimento do contrato grupal, no qual os acordos, regras e combinados serão firmados, que se estabelece o coconsciente. Ele "abarca todo e qualquer acordo ou explicação específica, vigente enquanto a peça teatral ou a intervenção sociopsicodramática durar" (RODRIGUES, 2016, p. 55). Há, ainda, outra parte, inconsciente, chamada de coinconsciente, uma vez que se configura no grupo e é "formada por conteúdos implícitos e compartilhados, os quais não são expressos individualmente, nem mesmo notados, como sítios arqueológicos sob nossos pés, ainda não descobertos" (RODRIGUES, 2016, p. 57).

O psicodrama entende que há uma dinâmica nas relações, que são criadas - e mantidas - por meio dos acordos feitos e das regras aceitas conscientemente, e também configurada por algo que permanece oculto, mas que se faz sentir e, de alguma forma, influencia no que se mostra a partir de uma ação ou jogo dramático.

Portanto, "o contexto dramático, na verdade, é o lugar da realidade suplementar, do jogo e do lúdico, do rito, da fronteira entre o imaginário e o real” (RODRIGUES, 2016, p.62). 
No texto Teoria dos Grupos, Maria da Penha Nery (2010) apresenta algumas fases que são observadas na formação e manutenção do grupo: horizontalização, diferenciação horizontal e diferenciação vertical.

A horizontalização, também chamada de isolamento orgânico ou identidade total, refere-se a uma indiferenciação entre os membros do grupo, momento em que estão todos na mesma situação, são "iguais", é uma fase amorfa em que os membros do grupo criam uma primeira relação com o líder ou coordenador do grupo. Prevalece um clima de tensão, insegurança, ansiedade e o líder ou coordenador tem um papel primordial, que é proporcionar um acolhimento emocional e dar sustentação aos membros do grupo para que se sintam seguros.

A diferenciação horizontal inicia um momento de diferenciação dos indivíduos, que passam a se perceber como integrantes do grupo, o clima ainda é tenso e há ansiedade na medida em que as interações vão ocorrendo e revelam-se as primeiras diferenças. $\mathrm{O}$ coordenador precisa então favorecer a independência entre os integrantes, favorecendo trocas complementares e propondo atividades que fortaleçam o grupo, deixando-o mais seguro, mas também valorizando a diferença, o único e o integrando ao grupo.

Já, a diferenciação vertical se dá quando os membros começam a centralizar a ação, surgem as primeiras lideranças e os interessados em segui-las ou não, surgem então conflitos e há oscilação entre admiração e competição; os sentimentos ficam mais em evidência. Ao coordenador é preciso evidenciar e encaminhar as divergências que vão surgindo, mantendo uma percepção atenta e ajudando o próprio grupo a se perceber dentro do mesmo.

É válido ressaltar que as três etapas são dinâmicas, podem ir e voltar conforme surjam acontecimentos e modificações, revelando o movimento orgânico do grupo. Percebendo o movimento do grupo, o coordenador deve avaliar a necessidade e a contribuição de cada um do grupo, pois "os primeiros movimentos do coordenador de um grupo objetivam estabelecer algum tipo de comunicação entre os participantes, promovendo exercícios de aquecimento que [...] mobilizam o grupo, delineando seus primeiros contornos" (KNOBEL; ALVES, 2008, p.71).

Na mobilização do grupo e na delineação destes primeiros contornos, o coordenador precisa ficar muito atento a quem são os integrantes do grupo, de onde vieram, quais são seus desejos, quais experiências são compartilhadas previamente entre ambos. "Podemos pensar que conforme o pertencimento social, étnico ou geográfico dos membros de um grupo, 
delineiam-se diferentes direitos, deveres e expectativas, tanto individuais como coletivos" (KNOBEL; ALVES, 2008, p.70).

Pode-se estabelecer conexões entre os referenciais junguiano e moreniano, no que se refere à dimensão criativa, plural, transformadora e atuante da psique. O interesse de Jung voltou-se para a rede de relações intrapsíquicas individuais e, assim, chegou ao inconsciente coletivo. Moreno, por sua vez, concentrou sua atenção e estudos no campo de relações interpsíquicas e no modo como propiciavam a transformação individual.

Até aqui podemos ver semelhanças entre os dois referenciais no que se refere à coordenação do grupo e na necessidade de manter-se um bom contrato no início. Assim, o campo simbólico construído pode vir a ser mobilizador e significativo, além de permitir o desenvolvimento da consciência, tanto em sua rede de relações intrapsíquicas, com seus conteúdos internos, quanto nas relações interpsíquicas, favorecendo o dinamismo eu-outro em múltiplos contextos. 


\section{O PROJETO DE PESQUISA}

Encontram-se apresentados neste capítulo o objetivo principal e os objetivos secundários, seguidos da metodologia utilizada e de parâmetros para análise do material obtido.

Para a realização da presente pesquisa foi necessária uma primeira etapa que compreendeu um cuidadoso planejamento dos encontros para obter a aprovação pelo Comitê de Ética em Pesquisa com Seres Humanos, que se deu através do preenchimento de informações e do envio do projeto para o site da Plataforma Brasil, responsável pela validação da pesquisa. A seguir, iniciou-se a divulgação e convite para participação no grupo vivencial de sonhos.

Formado o grupo vivencial de sonhos, deu-se início aos encontros, descritos de forma narrativa, e durante os quais se colheu todo o material necessário para análise. O material encontra-se registrado na forma de relatos de sonhos digitados, desenhos, modelagens em argila, fotografias e gravações dos encontros em áudio, além de questionários dirigidos e entregues ao final de cada encontro. 


\subsection{OBJETIVOS}

\subsubsection{OBJETIVO PRINCIPAL}

A presente dissertação de mestrado visa, à luz da psicologia analítica de Jung, acompanhar e trazer considerações a respeito do modo como os estudantes de $1^{\circ}$ ano vivenciam o período de entrada no curso de graduação em Psicologia de uma universidade pública do estado de São Paulo, a partir da participação em um grupo vivencial de sonhos criado com esta finalidade.

\subsubsection{OBJETIVOS ESPECÍFICOS}

Identificar símbolos emergentes dos encontros e nos sonhos compartilhados que foram registrados ao longo do grupo.

Observar e refletir sobre o movimento do grupo configurado pelas expressões e interações vividas pelos estudantes no decorrer da pesquisa.

Refletir sobre o alcance dos grupos vivenciais para a pesquisa, atendimento e formação de universitários ingressantes no curso de graduação em psicologia. 


\subsection{PROCEDIMENTOS METODOLÓGICOS}

Devido à natureza multifacetada e simbólica dos sonhos e à proposta de compartilhamento e elaboração dos mesmos em um grupo vivencial de sonhos com estudantes ingressantes no curso de graduação em psicologia, foi escolhido o método qualitativo para embasar esta pesquisa.

O método qualitativo abarca uma primeira etapa de coleta dos fenômenos a serem investigados, e uma etapa posterior de compreensão dos dados a serem analisados a partir de uma perspectiva simbólica dos mesmos.

Os sonhos foram escolhidos como material de trabalho para o grupo, dada a sua importância na psicologia analítica ao revelar o íntimo, e também o coletivo entre os indivíduos e, assim, permitirem variadas interpretações e compreensões.

Como parte do método qualitativo foi escolhido o grupo vivencial por conter e auxiliar o processo de elaboração simbólica do momento de entrada no curso de Psicologia. A constituição de um grupo vivencial possui características particulares que muito interessam quando se trata de observar o campo simbólico formado pela experiência compartilhada, uma vez que o grupo vivencial tem força para favorecer a expressão e o compartilhamento de experiências, pois é embasado numa perspectiva de acolhimento e sustentação.

Assim, procurou-se referências no estudo de Penna, autora que estudou as especificidades da pesquisa qualitativa com a abordagem da psicologia analítica. A autora relata que técnicas expressivas como sonhos, relaxamento, desenho, modelagem, são capazes de colher e acessar o material inconsciente, assim como questionários e entrevistas abertas ou semi-abertas, formulados de forma a captar conteúdos conscientes e inconscientes. (PENNA, 2005).

Para Whitmont, "o fenômeno psíquico investigado pela Psicologia Analítica é o símbolo, que constitui a única chave possível para o conhecimento" (WHITMONT, 1969, p. 83).

Sendo assim, para obter conhecimento pela ação do símbolo, que permite tornar o desconhecido compreensível para a consciência; e contribuir para o estudo acerca do modo como ingressam os estudantes de psicologia, foi necessário que se empreendesse uma compreensão articulada dos sonhos apresentados com os encontros do grupo em si e de sua 
produção simbólica que abrangesse as etapas de tradução, interpretação, elaboração e integração do símbolo à consciência através de associações, comparações, analogias e pela busca de sentido (PENNA, 2005).

Pensando justamente nas diversas considerações, significados e sentidos que os sonhos evocam, acredita-se que uma postura mais receptiva à esta multiplicidade pode contribuir não apenas para compreendê-los através de interpretações teóricas, mas de alimentá-los naquilo que possuem de mais autêntico e vivo: a multiplicidade de linguagens. Tal multiplicidade, que nesta pesquisa consistiu no trabalho com recursos expressivos e artísticos verbais e não verbais, agiu no sentido de permitir que múltiplas considerações, significados e sentidos pudessem crescer no grupo vivencial de sonhos, favorecendo assim a elaboração simbólica no grupo e pelo grupo.

Durante cada um dos encontros procurou-se viabilizar através das propostas planejadas a construção de um espaço propício e fecundo para a experimentação de múltiplas linguagens (escrita, desenho, relato verbal, relaxamento, modelagem em argila), visando favorecer a elaboração simbólica tanto dos sonhos quanto do movimento do próprio grupo ao longo dos encontros.

Houve o cuidado para que os participantes pudessem desfrutar positivamente desta pesquisa, não apenas como sujeitos que estão subordinados a certas variáveis da pesquisa, mas também como coautores, no sentido que poderiam exercitar sua autoria e participar das tentativas de compreensão e significação dos próprios sonhos e dos demais participantes, criando conhecimento em conjunto.

Assim, foi possível uma abertura para a ampliação das interpretações e significações dos sonhos a cada encontro, embasada por uma vivência do compartilhamento dos sonhos em grupo, em que houve respeito mútuo, suporte e acolhimento e ampliação da vivência e elaboração simbólica.

Evidenciou-se também a necessidade de enfatizar o aspecto da confidencialidade, a qual foi constantemente reiterada em todos os encontros, levando em conta que os participantes da pesquisa, a partir da realização desta, compartilhariam no mínimo cinco anos de convivência.

Neste âmbito, foi estruturada a presença de uma colaboradora da pesquisa, também psicóloga, que pudesse prontamente prestar auxílio mediante algum desconforto, além de 
incluir momentos para se falar das sensações e impressões suscitadas pelos sonhos em cada um dos encontros, o que foi previsto nos roteiros dos encontros.

Assim, procurou-se criar no próprio grupo um espaço para dar vazão às dificuldades e resistências e também um espaço de suporte e acolhida, ao promover momentos de diálogos antes e depois de cada atividade e reiterando a necessidade do sigilo e respeito a cada um dos participantes.

Conheci a colaboradora através das atividades promovidas pelo Ateliê Aberto do Laboratório de Estudos da Personalidade da USP (LEP-USP). O nosso primeiro contato foi feito através de e-mail, no qual marcamos uma conversa para que eu pudesse explicar a pesquisa e o seu papel, e assim, iniciamos nosso vínculo. Poder contar com a sua participação e sua experiência foi de extrema importância para esta pesquisa. 


\subsection{REGISTROS DOS ENCONTROS}

Devido à necessidade de analisar simbolicamente o material produzido, foi preciso pensar em formas de registrar os encontros, o movimento do grupo, os símbolos trazidos pelos sonhos e também os símbolos produzidos pelo próprio grupo.

Para responder à linguagem múltipla do símbolo, foram utilizados diversos recursos: gravações dos encontros em áudio, fotografias, produção de desenhos e escrita, realização de modelagens e composição de uma cena com as mesmas e também breves questionários a serem respondidos ao final de cada encontro.

Com a finalidade de trazer todo o processo simbólico fomentado nos encontros do grupo para uma (almejada) compreensão significativa tanto para a pesquisa quanto para cada participante, foi considerado importante que os participantes pudessem expor verbalmente a experiência para o grupo, e também poder ater-se a ela individualmente, incluindo-se assim a possibilidade organizadora da consciência, condensada na ação de refletir sobre o processo pelo qual se passou no ato de escrever.

Desse modo, foram elaboradas questões que cumpriram tanto a função de reflexão e organização para o estudante quanto a função de auxiliar na aquisição de maiores informações acerca da experiência do encontro em si, do meio expressivo utilizado e do movimento grupal.

Estas questões foram denominadas de Registro do Encontro e entregues digitadas numa folha de papel para serem respondidas no final do $2^{\circ}, 3^{\circ}$ e $4^{\circ}$ encontros. No $1^{\circ}$ encontro foram solicitadas três palavras a respeito da experiência e no $5^{\circ}$ encontro foi entregue um questionário final com 7 questões a respeito do grupo e da experiência como um todo. Algumas questões estavam presentes na maioria dos encontros e outras surgiram de acordo com a especificidade da atividade.

Assim como nos encontros do grupo houve o cuidado de mostrar a multiplicidade de sentidos e os desdobramentos possíveis para os símbolos dos sonhos, também para a análise dos encontros procurou-se manter a diversidade de olhares para integrá-los num todo ampliado. 


\subsubsection{RECURSOS DOS ENCONTROS}

Para que o grupo vivencial de sonhos pudesse se realizar seria necessário obter, por parte dos participantes - entre si e com a pesquisadora e colaboradora - confiança e abertura recíproca para o andamento do mesmo, aspectos que não se dão prontamente, pelo contrário, têm que ser cultivados e demandam tempo. Devido ao objetivo da pesquisa de procurar compreender a experiência de entrada no curso, que se dá nas primeiras semanas, os encontros precisaram estar contidos também nesse período. Dessa forma, pensou-se em cinco encontros, compreendidos logo no primeiro e segundo mês de entrada no curso de graduação. O primeiro encontro foi destinado a acolher o grupo e esclarecer a intenção da pesquisa e as atividades a serem realizadas; o segundo, terceiro e quarto encontros foram aqueles em que se desenvolveram as atividades e se evidenciou o dinamismo grupal; e o quinto encontro ficou com a tarefa de síntese e reflexão do grupo formado e dos encontros que se deram. Portanto, com esse número de encontros foi possível verificar diferentes momentos do grupo que em um número reduzido de encontros não seria possível.

Para cada um dos encontros foram elaborados roteiros prévios destinados a manter os objetivos da pesquisa, funcionando como fio norteador para que fosse possível conduzir o encontro de acordo com as atividades propostas. Tais roteiros eram, porém, permeáveis o suficiente para acolher o novo e o inesperado à medida que os encontros prosseguissem e o movimento do grupo se esboçasse.

Após cada encontro realizado, refletíamos sobre o encontro e suas vicissitudes, de forma a encontrar elementos que pudessem auxiliar no processo de elaboração simbólica para o próximo encontro. Em todos os encontros foram estimulados o questionamento, a formulação de opiniões e também a escuta, no intuito de que se sentissem chamados a pesquisar e se aprofundar nos símbolos dos sonhos, pois era muito importante que eles pudessem vivenciar e, de alguma forma, iniciar uma elaboração dos símbolos trazidos para o grupo.

Sobre a postura de receptividade aos encontros do grupo e ao self grupal, Freitas considera importante também colocar-se à espera do que virá:

Estar ali, ter uma proposta clara, uma delimitação quanto ao tempo, espaço e forma de trabalhar; e ainda assim, poder deixar acontecer, sintonizar com o processo que se desenrola, delegar ao self grupal o rumo e o ritmo do trabalho, além da definição dos símbolos mais 
pregnantes. E ademais, cuidar das próprias resistências, das expectativas e fantasias pessoais, observando-se o tempo todo, e "tomando fôlego" de vez em quando (FREITAS, 1995, p.53, negrito do autor).

\subsection{PARÂMETROS PARA ANÁLISE}

A análise dos resultados visa identificar o processo de elaboração simbólica do grupo e seus movimentos. A ênfase é no material expressivo obtido e cotejado com observações sobre os símbolos trazidos pelos sonhos e compartilhados no grupo ao longo dos encontros, e também o próprio movimento do grupo em si, enquanto organismo vivo.

O material de análise encontra-se na forma de registros escritos da pesquisadora e colaboradora, da transcrição do áudio gravado nos encontros, relatos escritos de sonhos, na forma de desenhos, e como fotografias das modelagens e de uma cena criada com as mesmas e das respostas aos Registro do Encontro e ao questionário final. Assim, a análise toma um caminho que considera a postura do pesquisador e suas influências, encontrando embasamento no trabalho de Penna:

\footnotetext{
Não se trata, no entanto, de anular as diferenças entre sujeito e objeto, pois isso inviabilizaria a própria possibilidade de conhecimento, visto que nela está implícita a presença do conhecedor, o sujeito, e do conhecido, o objeto, melhor dizendo, do desconhecido a ser conhecido (PENNA, 2005, p.85).
}

As análises apresentadas adiante estão configuradas na forma de um continuum simbólico, envolvendo temas e símbolos que rodearam os encontros e que perpassam a formação do psicólogo, como o arquétipo do mestre-aprendiz e do curador-ferido. Também foram utilizados recursos expressivos artísticos e verbais como facilitadores da elaboração simbólica, entendendo o resgate da palavra enquanto mediadora e organizadora da vivência individual e grupal. Além disso, o conhecimento dos procedimentos alquímicos foi retomado em alguns momentos no sentido de ampliar a sua emergência simbólica dentro do grupo e verificar o seu movimento. 


\subsection{A CONSTITUIÇÃO DO GRUPO VIVENCIAL DE SONHOS}

\subsubsection{CUIDADOS ÉTICOS}

Cuidados éticos foram tomados devido ao caráter expositivo que todo grupo, em si, requer e à possibilidade de que alguma questão dolorosa pudesse ser trazida à tona no momento das atividades, ou mesmo alavancada pelos sonhos. Soma-se a isso o fato de que a população da pesquisa foi composta por estudantes recém-ingressantes à graduação, havendo ainda por compartilhar no mínimo cinco anos de convivência.

O projeto de pesquisa foi submetido à avaliação pela Plataforma Brasil em 29/07/2014 e aprovado pelo Comitê de Ética em Pesquisa com Seres Humanos (CEPH). A identificação do projeto é CAAE: 34092714.7.0000.5561.

\subsubsection{DIVULGAÇÃO}

A pesquisa teve como foco os estudantes ingressantes ao curso de Psicologia de uma universidade pública estadual de São Paulo. Sendo assim, o critério para participação no grupo foi pertencer ao $1^{\mathrm{o}}$ ano do curso de Psicologia e ter interesse e disponibilidade para o compartilhamento de sonhos em grupo.

A partir da autorização do Comitê de Ética em Pesquisa com Seres Humanos, iniciouse a divulgação e o convite para participação no grupo já na semana de recepção aos calouros. Foram deixados convites impressos (ANEXO A) em locais de intensa circulação de estudantes, como o Centro Acadêmico e a biblioteca, murais da faculdade, além da realização de conversas com o público alvo.

Para uso exclusivo da pesquisa de mestrado e comunicação com os estudantes interessados, foi criada a conta de e-mail: grupovivencialdesonhos@gmail.com e esta foi divulgada como meio oficial de contato e manifestação de interesse.

Após a divulgação, numa $6^{\mathrm{a}}$ feira, poucos dias antes do início previsto do grupo, um cartaz de divulgação foi fixado no corredor de aulas, ficando eu ao lado dele para convidá-los pessoalmente e explicar melhor a pesquisa. Percebi que desta forma pude me apresentar e realizar o convite para a pesquisa de forma mais próxima e calorosa. Assim, um pequeno grupo foi se formando e, neste momento, os que já haviam manifestado o interesse por e-mail puderam me conhecer e tirar dúvidas e outros mais vieram a se interessar pela proposta. 
Então, eu os acompanhei até a Sala Ateliê, local em que aconteceriam nossos encontros. Combinamos de nos encontrarmos no saguão próximo à Sala Ateliê na $2^{\mathrm{a}}$ feira seguinte. A Sala Ateliê possui um espaço físico adequado a realização de grupos e atividades expressivas, pois é ampla, contém colchonetes, cadeiras, pias, bacias e materiais gráficos, além de garantir privacidade. O número mínimo e máximo de participantes foi obtido pensando-se na capacidade máxima da sala para oferecer conforto a todos os participantes e também no número mínimo para que se estabelecesse um grupo, sendo assim, entre 3 e 15 seria considerado um número propício ao andamento da pesquisa.

\subsubsection{A FORMAÇÃO DO GRUPO}

Foram realizados cinco encontros semanais nos meses de Março e Abril, às segundasfeiras, das $14 \mathrm{~h}$ às $15 \mathrm{~h} 30$, na Sala Ateliê. O primeiro encontro do grupo realizou-se na $3^{\mathrm{a}}$ semana de ingresso ao curso de graduação, contando-se a semana de recepção. O primeiro encontro deu-se em 08/03, o segundo em 15/03, o terceiro em 23/03, o quarto ocorreu em 06/04, devido ao feriado de Corpus Christi e o último encontro em 13/04.

Até o primeiro dia do grupo eu não sabia ao certo o número de participantes, visto que apareceram pessoas novas que não haviam feito contato comigo na $6^{\mathrm{a}}$ feira anterior e, por outro lado, pessoas que estiveram presentes nesta $6^{\mathrm{a}}$, mas que optaram por não participar. Finalmente, o grupo foi formado por 13 participantes, sendo 7 do sexo feminino e 6 do sexo masculino, com idades entre 17 e 20 anos.

No último encontro do grupo foi solicitado para que escolhessem nomes fictícios para serem reportados nesta dissertação, caso fosse necessário. Assim, os participantes são: Laura, Catarina, Amélia, Valkyria, Anna, Leonardo, Ana Maria, Heitor, Cristóvão, Sofia, Pedro, Patrícia e Beth. Duas participantes não puderem comparecer no último encontro, porém as encontrei pela faculdade e disseram que poderia criar qualquer nome. Vale comentar que dois nomes não têm correspondência com o sexo real do participante.

É importante ressaltar também que ao longo do grupo vivencial de sonhos não foi possível trabalhar com todos os sonhos. Os participantes presentes fizeram as atividades expressivas dos encontros em questão, mas apenas um sonho foi escolhido e tomado para análise pelo grupo, o que se deu nos três primeiros encontros do grupo. 


\section{OS ENCONTROS VIVENCIAIS E OS RESULTADOS DA PESQUISA}

A análise do grupo vivencial de sonhos prosseguiu na direção de observar os símbolos trazidos pelos sonhos e compartilhados no grupo, atentando para o dinamismo deles. A ênfase recaiu na observação do movimento do grupo e na consideração do material obtido dos encontros. Os relatos manuscritos dos sonhos e os desenhos foram analisados tendo em vista o material original produzido. As modelagens e a cena final criada a partir das mesmas estão disponíveis através de fotografias (ANEXO I) e os encontros gravados em áudio foram transcritos para que os trechos selecionados pudessem ser organizados no capítulo 4.

Apresento aqui o que foi planejado para cada um dos encontros, justificando a escolha pelas atividades propostas. Houve atenção constante para acompanhar o movimento do grupo, buscando formas de favorecer a construção de um self grupal.

Também estão acrescidas as considerações que eu e a colaboradora elaboramos ao final de cada encontro, período no qual refletíamos sobre o que havia ocorrido e começávamos a pensar sobre a coordenação e as atividades do próximo.

A princípio, antes do início do grupo, já havia pensado e estruturado diversas atividades relacionadas ao uso de escrita, desenho, colagem, modelagem e expressão dramática. Não pude realizar todas as atividades propostas previamente, e procurei seguir o movimento do grupo. Também optei por atividades que pudessem promover a manutenção do self grupal, além de ajudar a lidar com a ansiedade e com alguns temas que foram aparecendo.

Os encontros contaram com certas estruturações. De modo geral, no início de cada encontro, nós formávamos uma roda e conversávamos sobre os sonhos, a semana transcorrida e sobre a repercussão do encontro passado. Em seguida, havia um aquecimento, que nos preparava para a atividade expressiva principal, na qual seriam compartilhados os sonhos. Após a atividade, conversávamos a respeito da mesma e do que ela provocou, em termos de novas percepções, desconfortos, emoções, para, em seguida, escolher um sonho para se compartilhar em grupo. No final de cada encontro era entregue o Registro do encontro, cuja função era promover síntese e organização pela consciência da experiência emocional suscitada e também fornecer dados a respeito do movimento do grupo. 


\section{PRIMEIRO ENCONTRO}

O primeiro encontro foi dedicado ao contrato inicial com o grupo e às apresentações da pesquisa, da pesquisadora e da colaboradora e também dos integrantes, mas destes últimos por meio de uma atividade lúdica.

Esta apresentação lúdica consistia em fazer uma apresentação pessoal, incluindo nome, idade e também o interesse pelos sonhos, seguida pela escolha de outro participante a se apresentar, que seria sinalizada ao jogar uma pequena bola de plástico ao escolhido, que se apresentaria e jogaria a bolinha para outro, e assim sucessivamente. Após a apresentação, deveriam escolher novamente um dos participantes e devolver aquilo que se lembravam da apresentação dele, também por meio da bolinha.

Com esta atividade pretendi mostrar, de uma forma mais descontraída, que cada um lembra de um aspecto diferente sobre o outro e que aí reside uma diversidade que nos orientaria durante os encontros. Também busquei avisar que os comentários a serem feitos durantes os encontros deveriam ser pautados no reconhecimento de que se trata de uma observação e opinião pessoal, as quais não encerram a verdade sobre o significado do sonho, muito menos acerca da pessoa que o sonhou. Sendo assim, o que nos interessaria no compartilhamento dos sonhos seria a consideração de múltiplos pontos de vista que viriam a integrar e compor o próprio grupo.

Após a apresentação, iniciamos uma conversa a respeito da atividade realizada e também sobre o que pensavam a respeito dos sonhos, a frequência com que se lembravam deles e a importância dada e, também, sobre as expectativas para com o grupo e as nossas atividades. Assim, pude ir percebendo o perfil do grupo, se já possuíam conhecimentos ou não e de como forma se relacionavam com seus próprios sonhos.

Também havia planejado um primeiro contato com o compartilhamento de sonhos através da escrita, recurso muito utilizado nos anos de estudo no colégio, cursinho e, agora, faculdade. Seu uso poderia proporcionar menor resistência neste primeiro momento, de promover uma apresentação inicial ao uso de recursos expressivos, além de propor uma nova maneira de utilizar a escrita.

Em seguida, orientei para que eles se levantassem, movimentassem o corpo, andassem um pouco pela sala e então escolhessem um lugar confortável para escrever o relato de um 
sonho, com esta instrução, procurei atenuar um pouco a ansiedade inicial ao incentivá-los a reconhecer o ambiente e a encontrar seu lugar nele, estimulando uma iniciativa pessoal nesta escolha.

Enfatizei também que procurassem se recordar de um sonho marcante, importante, que tivesse despertado curiosidade, de preferência um sonho recente, e que gostariam de compartilhar, de doar para o grupo. Apesar de a minha intenção inicial ter sido analisar símbolos que se expressam em sonhos recentes e relacionados à entrada na faculdade de Psicologia, optei por deixar que pudessem ter um grau de autonomia nessa escolha e considerei que trouxessem outro sonho, seja antigo, enigmático, marcante, recorrente, visto que ele poderia estar de alguma forma relacionado com esse momento de ingresso, respeitando assim o conceito junguiano de autonomia e atemporalidade do inconsciente.

Havia material gráfico e folhas de sulfite no centro da roda que poderiam utilizar. Neste momento, coloquei uma música suave de fundo, com sons da natureza, visto que a música é um recurso bastante mobilizador, favorecendo o relaxamento.

Quem terminasse de escrever e sentisse vontade de compartilhar o relato do sonho poderia colocar a sua folha de papel na roda, ou poderia dobrá-la ao meio, o que seria entendido como não disponibilidade para a leitura e compartilhamento em grupo.

Solicitei voluntários para escolher e ler um dos relatos de sonho dispostos. Assim que uma participante se prontificou e realizou a leitura, prosseguimos para um momento de associações, em que cada integrante comentou o que havia considerado relevante, o que gostou ou não e o que sentiu ao ouvir o relato. Pedi permissão para levar os relatos dos sonhos e trazer de volta no próximo encontro e eles concordaram.

Ao final do encontro, tratamos de estabelecer o contrato, que, conforme mencionado por Freitas (2014), visa a comprometer os participantes em relação ao sigilo e à participação, bem como organizar a duração dos encontros do grupo. Ressaltei também a importância da pontualidade, além de valorizar a privacidade de cada um, garantindo que nenhum participante na pesquisa seria identificado e que os resultados da pesquisa seriam disponibilizados após sua conclusão.

Foram entregues pequenos pedaços de papel, nos quais solicitei que cada participante escrevesse três palavras sobre o encontro. Com esta atividade, procurei tanto oferecer um modo de registrar e conceituar a experiência para os participantes, quanto obter informações a 
respeito de como foi esse primeiro momento para eles. E, finalmente, foi entregue, lido em voz alta, e assinado o Termo de Consentimento Livre e Esclarecido (ANEXO B).

Após o primeiro encontro, eu e a colaboradora sentimos que o grupo recém-formado era curioso, interessado, aberto e comunicativo. Logo de início, foi compartilhado um sonho bastante forte e pessoal, o que nos fez perceber que a disponibilidade e vontade de experimentar deveria ser observada, para que não se sentissem expostos e invadidos, atentando para o movimento de se abrir e se fechar tanto para os próprios conteúdos aflitivos, quanto para os momentos de se expor ou acolher no grupo. 


\section{SEGUNDO ENCONTRO}

Iniciamos o segundo encontro com uma conversa sobre a experiência do encontro anterior e sobre a semana que havia passado. Fui percebendo que essa rodada de conversa já estava se constituindo em nosso ritual habitual, conferindo espaço para ouvir e serem ouvidos. Além disso, todo o material que usaríamos nas atividades era disposto no centro da roda, de modo a criar um campo compartilhado.

Retomamos alguns pontos do contrato inicial, já abordados no encontro anterior a respeito da coleta dos dados da pesquisa e também do uso do gravador para obter o material para análise. Também os consultei sobre a possibilidade de uso de fotografias para registrar a produção, afirmando que não seriam expostos nem identificados pessoalmente. Também pedi permissão para ficar com os relatos dos sonhos e os materiais produzidos e me comprometi a devolvê-los após a conclusão da pesquisa. Os participantes consentiram com todos os aspectos e, assim, a partir do $2^{\circ}$ encontro iniciou-se a gravação em áudio.

Procurei enfatizar que na presença de qualquer incômodo ou angústia poderiam e deveriam nos avisar e era muito importante manter respeito, acolhimento e privacidade a cada participante do grupo, visto que teriam muito tempo de convívio pela frente. Expliquei novamente que os sonhos seriam analisados tendo como fio condutor o desenvolvimento do grupo e não os símbolos individuais, e que a análise estaria centrada nos temas e/ou situações recorrentes entre eles, sendo que o sonho seria valorizado como linguagem e experiência, uma vez que o foco era a vivência do sonho e dos símbolos em grupo.

Após a conversa inicial, organizei os relatos escritos dos sonhos no centro da roda e solicitei que cada um identificasse e lesse o seu novamente, em silêncio. Então conversamos a respeito do que emergiu a partir da leitura. Também decidimos em conjunto que cada participante poderia trazer sonhos novos a cada encontro ou trabalhar com o mesmo sonho.

A partir daí, começamos um alongamento, em que cada um do grupo sugeria um movimento e todos copiavam. Em seguida, pedi para escolherem um lugar confortável na sala para se deitarem e iniciarmos um relaxamento dirigido que durou aproximadamente 15 minutos. Utilizei um $\mathrm{CD}$ de músicas para meditação para auxiliar no momento de introspecção. 
O relaxamento prévio à realização do desenho teve o intuito de resgatar e deixar mais vivas as memórias dos sonhos, além de chamar a atenção para o modo como o corpo reagia à evocação do sonho. Quando o relaxamento terminou, informei que poderiam pegar papel e lápis de cor, canetas ou giz de cera, recorrendo ao uso das cores para fazer um desenho sobre algum aspecto do sonho, por exemplo, o cenário, o sentimento mobilizado, a situação trazida ou mesmo algum personagem que se destacou.

O uso do desenho visava a experimentar uma nova forma de ver o sonho, a partir da representação bidimensional e com ela, vislumbrar novas perspectivas, e, sendo possível, a elaboração simbólica a partir do vivido.

Assim que foram terminando, poderiam colocar títulos nos desenhos e quem sentisse vontade de compartilhá-los que colocasse o seu no centro da roda. Houve um momento de observar e conversar sobre os desenhos, até que um deles foi bastante comentado e então escolhido para ser compartilhado no grupo.

A quem lembrou ou trouxe um sonho novo pedi para trazê-lo por escrito para que eu pudesse tê-lo registrado e usá-lo na análise. Em seguida, entreguei o primeiro Registro do encontro para ser respondido, o qual continha as seguintes questões:

1) Este encontro, em três palavras, foi...

2) Experimentar o meu sonho a partir dessa atividade...

3) O que levo daqui...

4) O que deixo aqui...

Após o encontro, eu e a colaboradora percebemos que da forma como os encontros estavam se desenrolando, com as etapas e atividades previstas, seria muito difícil de todos conseguirem contar o sonho para o grupo, porém, era extremamente importante e necessário que pudessem ter a experiência de contar os sonhos. Desse modo, pensamos que o contar sonhos em dupla poderia ser de grande ajuda nesse momento, além de favorecer a criação de vínculos. 


\section{TERCEIRO ENCONTRO}

Iniciamos o terceiro encontro como os anteriores, sentados em roda e conversando sobre a experiência que vinha sendo construída pelo grupo, sobre como passaram a semana anterior e como o encontro anterior e as atividades estavam repercutindo neles.

Como aquecimento para a atividade de contar sonhos em dupla, fizeram a leitura de alguns parágrafos selecionados sobre a abordagem junguiana aos sonhos. Cada participante leu um parágrafo. Optei por não aprofundar a consideração de cada parágrafo lido neste momento, a fim de deixá-los reverberando no encontro.

Essa leitura não foi prevista no meu planejamento, uma vez que não era a intenção da pesquisa realizar um grupo com fins pedagógicos, porém, avaliei, naquele momento, que pudesse proporcionar uma coesão e uma base ao que estávamos experimentando. Hoje, refletindo sobre o processo e os encontros, vejo que o apelo ao contexto pedagógico veio, em mim, como uma alternativa para conter a angústia que começava a se expressar no grupo, uma vez que a teoria também desempenha um papel de contribuir para a criação de continência.

Apesar de ter incluído momentos para se falar de cada etapa da experiência, em grupo, e também ter organizado um Registro do encontro, individual, justamente com a finalidade de chamar a função discriminadora da consciência, parecia haver muito conteúdo a ser lidado e busquei recursos que não restringissem ou impedissem sua emergência, mas oferecessem continência, permitindo que cada um se sentisse dentro, fazendo parte, constituindo um continente apropriado e que permitisse a transformação do conteúdo.

Terminada a leitura, prosseguimos com a atividade de compartilhar o sonho em duplas, sem o uso de um recurso artístico adicional. Devido ao número ímpar de participantes, formaram-se cinco pares e um trio, que se uniram para contar os sonhos entre si. Os participantes sugeriram que as duplas fossem formadas a partir da posição em que se encontravam dispostos na roda e assim foi feito.

A atividade de contar o sonho teve duração aproximada de 10 minutos, e, em seguida, passamos para um momento em que as duplas comentaram acerca da experiência, identificando semelhanças ou diferenças entre o jeito de sonhar e os temas e sentimentos trazidos pelo sonho. 
Então, sugeri que quem sentisse vontade de falar sobre o sonho que o compartilhasse no grupo. Um dos participantes logo se voluntariou, o qual parecia, para mim e para a colaboradora, estar com dificuldades de se entregar ao grupo. Assim, conversamos sobre o seu sonho, que acontecia na própria faculdade e trazia uma situação em que sentia peso e alívio, que foi reconhecida também por outros participantes.

Houve uma mobilização afetiva intensa e optei por encerrar o encontro com uma atividade que também não havia previsto, mas que no momento senti que poderia ser válida: sugeri que todos se levantassem, espreguiçassem e andassem um pouco pela sala e então imaginassem que o corpo estava coberto de areia ou poeira, a qual precisaria ser "varrida", através de movimentos leves e firmes com a mão por todo o corpo. Quem sentisse vontade também poderia ajudar o participante ao lado ou mesmo os demais.

Assim que terminaram a atividade, solicitei que preenchessem o Registro do encontro, o qual foi entregue em seguida e continha as questões:

1) Este encontro, em três palavras, foi...

2) Receber o sonho do meu colega...

3) Oferecer o meu sonho para o colega/grupo...

4) O que levo daqui...

5) O que deixo aqui...

Ao finalizar o encontro, eu e a colaboradora sentimos que, apesar de ter sido uma vivência forte, foi muito importante que o grupo pudesse ter chegado a este ponto e a esta expressão.

A atividade com modelagem já estava prevista e assim, decidi por utilizá-la no próximo encontro, principalmente para concretizar e dar forma ao que estavam sentindo. 


\section{QUARTO ENCONTRO}

Do terceiro para o quarto encontro houve um espaçamento de uma semana, devido ao feriado de Corpus Christi. Um dos participantes não pôde comparecer, mas já nos havia avisado no encontro anterior. Conversamos sobre como haviam passado as últimas semanas, como estavam se sentindo com os encontros e se continuavam lembrando dos sonhos ao longo das semanas.

Iniciei a explicação da atividade do dia, que consistia em fazer modelagens de argila a partir de aspectos dos sonhos compartilhados entre si.

De acordo com Freitas: "a argila remonta à terra, ao barro de que, segundo o mito, Adão foi feito, e nos remete à criação e ao criador [...] permite um trabalho fluente valendo-se apenas das mãos e dispensando quaisquer instrumentos" (FREITAS, 1990, p. 80).

Mais uma vez, optei pelo compartilhamento de sonhos entre os participantes, levando em conta o potencial alcançado no último encontro. Além disso, entendi que poderiam ser mobilizadas questões relativas à identificação e diferenciação no grupo e, assim, propus que modelassem aspectos dos sonhos que fossem contados a eles e não os próprios.

Assim, em roda, contaram o sonho baixinho para o participante ao lado com o auxílio do gravador, para que o relato do sonho ficasse registrado em áudio. Com essa forma de compartilhamento "confidencial" busquei destacar de forma lúdica o aspecto privativo e íntimo do sonho e a elaboração e transformação que pode se dar quando nos dispomos a nos abrir e confidenciá-lo, trazendo enriquecimento e novas perspectivas.

Porém, só pude realizar essa atividade um tanto audaciosa ao perceber a vinculação do grupo e o ambiente de cuidado, criatividade e acolhimento que se dava, entendendo que o ambiente em que o sonho seria exposto era capaz de contê-lo.

Aquele que ouviu o relato do sonho prosseguiria a atividade relatando o seu sonho para o participante ao lado e assim sucessivamente, como a brincadeira de telefone-sem-fio, até chegar no participante que iniciara a atividade. Com esta atividade, minha intenção foi propiciar uma vivência coletiva e implicada em oferecer e receber uma nova perspectiva a partir do outro. 
Neste encontro não houve etapa de aquecimento preliminar à atividade. O que se tornou o aquecimento foi o contato manual com a argila e alguns até criaram formas fortuitas

Para a realização da modelagem, cada um dos participantes recebeu uma tigela de plástico de dimensão aproximada de $35 \times 35 \mathrm{~cm}$, uma pequena tábua de madeira, medindo aproximadamente $30 \times 20 \mathrm{~cm}$, que serviu de suporte para a modelagem, um pacote de $1 \mathrm{~kg}$ de argila e sacos plásticos grandes, para forrar os colchonetes e facilitar a limpeza posterior. Também foram deixadas toalhas de papel no centro da roda e havia a opção de pegar água na pia se assim decidissem.

Durante a atividade utilizei um CD de músicas africanas, contendo faixas mais animadas, mas também faixas mais calmas, entendendo que a melodia rítmica poderia contribuir no processo.

Sobre o potencial da música, esta pode criar um continente facilitador da entrega para o trabalho, sendo bastante propícia a alternância entre músicas mais introspectivas para os momentos de confecção das produções, ou mais eliciadoras de movimentação nos aquecimentos, sendo a escolha variável, de acordo com o que se deseja mobilizar (FREITAS; HALPERN-CHALOM, 2006).

Durante o processo íamos conversamos sobre o que estavam pensando a respeito da modelagem enquanto recurso expressivo para o sonho e suas possibilidades e limitações, porém não houve tempo suficiente para fazer uma rodada com todos os participantes, o que ficou para o próximo encontro.

Quando as modelagens foram finalizadas, solicitei que tanto o modelador quanto o sonhador criassem, cada um, um título sobre as mesmas e o escrevesse num pequeno pedaço de papel a ser colocado próximo à peça criada para o registro fotográfico.

No final, quiseram ajudar na limpeza da sala e no transporte das modelagens para as prateleiras da Sala Ateliê, a fim de facilitar a secagem e o cuidado com as peças. Entreguei o Registro do encontro, cujas perguntas foram as seguintes:

1) Este encontro, em três palavras, foi...

2) Ouvir o sonho do meu colega...

3) Modelar um aspecto do sonho do meu colega...

4) Ver um aspecto do meu sonho modelado...

5) O que levo daqui... 
6) O que deixo aqui...

Ao final do encontro, percebemos que o grupo estava mais tranquilo e relaxado e que a atividade da modelagem havia sido prazerosa e divertida. Nós duas também ficamos com vontade de modelar o sonho uma da outra e o fizemos, porém não as compartilhamos. Depois, nos perguntamos o que poderia ter nos mobilizado para realizar a modelagem também. O que será que em nós também solicitava materialização e concretude? Sentirmo-nos participando do grupo de maneira mais integral? Expressar e reconhecer o campo definido pelas polaridades inspiradas nos arquétipos do mestre-aprendiz ou do curador ferido - talvez do pesquisador-pesquisado? 


\section{QUINTO ENCONTRO}

Iniciamos o último encontro com duas ausências e alguns participantes atrasados. Começamos com uma atividade de relaxamento a partir dos pés, que não havia sido prevista, e surgiu espontaneamente, sugerida e executada pela colaboradora. Ela orientou os participantes a ficar em pé, fechar os olhos e passar uma bolinha de tênis, material do próprio Ateliê e de uso coletivo, em todas as partes do pé, no calcanhar, nos dedos e pressionar a mesma em diferentes regiões para observar se há alguma dor ou incômodo e como o corpo reage de um modo geral à atividade.

Finalizada a atividade de relaxamento, conversamos sobre o processo de modelagem do encontro anterior e os participantes puderam compartilhar suas opiniões e visões enquanto modeladores e sonhadores. Também conversamos sobre como estavam se sentindo em relação ao fim do grupo, para que se pudesse expressar os sentimentos relativos ao próprio grupo também, não apenas aos sonhos e atividades.

Em seguida, expliquei a atividade do último encontro, que envolvia a composição de uma cena coletiva com as modelagens feitas, assim, seria possível, de fato, compor e observar as situações e relações a partir do uso daquilo que construíram e que permeava o self grupal. Nesta composição seria possível modificar peças de lugar, e experimentar possíveis posições

para elas. Solicitei que durante a montagem dessa cena falassem uma palavra que representasse a experiência do grupo para cada um deles

Desse modo, a construção da cena poderia ajudar na apreensão da experiência, atuando na organização e entendimento do vivido e construído, concreta e simbolicamente.

Assim que terminaram de compor a cena, passamos para um momento de leitura da mesma, em que cada um foi falando sobre suas impressões e interpretações, momento que se mostrou como a possibilidade de uma síntese da experiência com o grupo e também da elaboração de uma perspectiva conjunta para o curso de psicologia.

Reafirmei o oferecimento dos dados da pesquisa e a garantia do sigilo e privacidade e aproveitei também para lembrá-los da importância de manter respeito e privacidade entre si, principalmente porque ainda conviveriam por bastante tempo.

Solicitei aos participantes que escolhessem um nome fictício caso fosse necessário citá-los na pesquisa. Enquanto isso, fotografei a composição final. Como o tempo havia sido 
ultrapassado, decidimos que eu entregaria o questionário final, o qual substituiu e ampliou o Registro do encontro. As questões elaboradas para o questionário final procuraram abarcar aspectos da avaliação da experiência pelos participantes no que diz respeito ao grupo, às expectativas, ao uso de recursos expressivos, da percepção sobre os sonhos e à relevância para a formação em psicologia. Seguem abaixo as questões:

1) Como foi participar do grupo vivencial de sonhos?

2) Qual foi o impacto de estar em um grupo falando sobre seus sonhos e ouvindo os sonhos dos demais? Como você se sentiu?

3) Qual dos recursos expressivos/artísticos apresentados no grupo (escrita, desenho, relato verbal e modelagem) você considera que contribuiu para a compreensão dos seus sonhos? Por quê??

4) Você acredita que essa experiência possa ter relevância para sua formação como psicólogo? Por que?

5) Qual era a sua expectativa em participar do grupo vivencial de sonhos?

6) Antes da sua participação no grupo vivencial de sonhos como você entendia e lidava com seus sonhos? E após ter participado do grupo, houve alguma mudança?

7) Você tem alguma sugestão ou comentário?

Combinamos que os questionários seriam enviados pelo mesmo e-mail com o qual fizeram o primeiro contato comigo na pesquisa. Tivemos um momento de agradecimentos e, assim, finalizamos o último encontro. 


\title{
5. OS RESUltAdos E SUA ANÁliSE: UM PERCURSO DE ELABORAÇÃO SIMBÓLICA
}

\author{
“Caminhante, são tuas pegadas o \\ caminho e nada mais; \\ caminhante, não há caminho, \\ se faz caminho ao andar". ${ }^{4}$
}

Antônio Machado

Ao longo dos cinco encontros realizados foi possível perceber que muitos sonhos e temas reverberaram e encontraram continuidade e continência nos encontros seguintes, bem como puderam ser ampliados e integrados ao grupo. Os sonhos, as atividades propostas e as considerações feitas pelos participantes indicaram progressiva constituição do grupo como verdadeiro continente, permitindo que se considerasse de fato a emergência de um self grupal, em que os sonhos e o desenvolvimento grupal e dos participantes mantiveram uma comunicação simbólica, um respondendo ao outro, permitindo retomadas e complementações.

É importante reiterar que nem todos os sonhos trazidos pelos participantes puderam ser compartilhados no grupo. Apenas três sonhos puderam ser trabalhados conjuntamente, sendo um sonho por encontro nos três primeiros encontros. No $3^{\circ}$ encontro, o compartilhamento do sonho em grupo foi precedido pelo compartilhamento de sonhos em duplas. No $4^{\circ}$ encontro os sonhos foram compartilhados em pares, mas registrados com ajuda de um gravador. No $5^{\circ}$ encontro houve a tentativa de elaboração simbólica da experiência no grupo, por meio da criação de uma cena em conjunto utilizando-se das modelagens realizadas no $4^{\circ}$ encontro.

Em relação aos Registros dos encontros, encontram-se nos ANEXOS C, E, G e H as respostas literais de cada participante, porém aqui procurei agrupá-los e analisá-los, entrelaçando ao movimento esboçado pelo grupo, o que está indicado em Contribuições do Registro do encontro.

\footnotetext{
${ }^{4}$ Citação disponível em http://blogs.utopia.org.br/poesialatina/cantares-antonio-machado/ Acesso em 02/02/2017.
} 
Há um grande número de sonhos que permearam o desenrolar do grupo, mas cujo conteúdo permaneceu não explicitado no self grupal. Considera-se que, de alguma forma, integraram o self grupal, ora enquanto pano de fundo, ora sendo compartilhados. O self, seja individual ou grupal, tem seus aspectos conscientes e inconscientes e está sempre num movimento incessante.

Sendo assim, desenvolvo com mais profundidade os resultados obtidos em cada um dos encontros, além de articulá-los como um todo, incluindo também o material que não pôde ser trabalhado em conjunto. Retomei alguns temas e questões e esbocei um caminho de análise que considera e resgata tais circulações, perfazendo assim, o meu caminho de elaboração simbólica enquanto pesquisadora. 


\section{PRIMEIRO ENCONTRO: ASSUMINDO ESCOLHAS}

O grupo foi recebido no saguão próximo à sala Ateliê, espaço que havíamos conhecido na semana anterior, quando encontrei com alguns deles pela primeira vez e fiquei ao lado do cartaz, fazendo um convite pessoal. Chegavam animados, falantes, sorridentes e, além disso, foram pontuais. Eu já havia preparado a sala, dispondo tapetes de E.V.A. ${ }^{5}$ e colchonetes no chão. Quando finalmente entraram na sala, eu disse que poderiam colocar as mochilas em cima de algumas mesas ao lado e tirar os calçados, se quisessem, para sentar nos colchonetes e formar uma grande roda.

Iniciamos o encontro com uma breve apresentação minha, da colaboradora, e da pesquisa. Passamos então para um recurso lúdico de apresentação, já explicado no capítulo 4.

Foi interessante observar que alguns dos participantes foram mais "lembrados" do que outros, principalmente aqueles que falaram sobre ter sonhos bizarros e loucos ou que a criatividade dos sonhos não conhecia limites.

Aproveitei para pontuar que no momento de se pensar, falar, explorar e interpretar sonhos acontece algo semelhante, havendo uma multiplicidade de opiniões e sensações, e que o respeito pelo conteúdo do sonho do participante era de extrema importância. Sendo assim, enfatizaríamos o caráter do "Eu sinto...", “Eu acho...", para que as opiniões não fossem tidas como um julgamento e sim como um complemento, um posicionamento pessoal, uma contribuição. Achei importante que sentissem que o grupo fazia parte de uma pesquisa, mas também de uma experiência em si e as informações trazidas visavam a estimular a curiosidade e a lembrança dos sonhos e não dar uma aula sobre interpretação.

Após a apresentação, iniciei a conversa sobre o conhecimento e relacionamento que mantinham com os sonhos e, também, as expectativas para com o grupo e as nossas atividades. Foi interessante observar que a maioria relatou ter sonhos muito loucos, bizarros, sem sentido, e alguns os compararam a videogames e jogos de $\mathrm{RPG}^{6}$. Em geral, comentaram lembrar-se pouco dos sonhos, mas quando lembravam frequentemente os contavam para familiares e amigos.

\footnotetext{
${ }^{5}$ Material muito usado em artesanatos e na confecção de esteiras e tapetes, cuja sigla acetato-vinilo de etileno deriva do inglês: Ethylene Vinyl Acetate

${ }^{6}$ Role-playing game é a nomenclatura em língua inglesa para um jogo de representação, no qual os jogadores assumem papéis de personagens e criam narrativas conjuntas.
} 
Além disso, muitos já traziam alguma bagagem sobre sonhos, símbolos e até mesmo conceitos de Jung, como inconsciente coletivo e arquétipos. Era perceptível o tamanho da vontade do grupo em saber mais sobre sonhos e o quanto se mostravam disponíveis para o trabalho em grupo. Alguns falaram do grande interesse em ouvir sobre os sonhos dos outros e sobre o que eles achariam dos seus próprios sonhos.

Em seguida, quando passamos para a atividade de escrever o relato de um sonho, foi muito bonito ver o modo como se abriram para essa experiência, ocuparam todo o espaço do Ateliê, se esparramaram nos colchonetes, dando vazão à escrita dos sonhos. A maioria estava confortável e até explorando lugares mais inusitados da sala, como uma pilha de colchões e um espaço embaixo de mesas, saindo do espaço delimitado pelos colchonetes.

Tamanha abertura e disponibilidade impressionou positivamente, mas também alertou para o fato de uma possível tensão e ansiedade relacionada ao desconhecido e à exposição, sendo necessário atentar para um risco de vulnerabilidade que o próprio movimento de entrega e recolhimento produz, ao simultaneamente impulsionar para o processo de reconhecimento e criação de limites e contornos internos e externos, no caso, o grupo.

Quando a maioria já dava sinais de estar terminando a atividade, como ficar se ajeitando no lugar ou conversar baixinho com quem estava do lado, aproveitei para pedir que voltassem à roda e que aqueles que sentissem vontade de doar o sonho para o grupo deixassem o relato do sonho no centro da roda e que aqueles que ainda não se sentissem prontos poderiam dobrar a folha ao meio. Dois participantes dobraram suas folhas.

Sobre a experiência de relatar por escrito os sonhos, alguns comentaram que nunca haviam escrito um relato de sonho antes. Alguns disseram ter gostado e outros terem tido dificuldade.

Com todos os sonhos registrados por escrito e dispostos no centro da roda, pedi voluntários para escolher e ler um dos relatos de sonho dispostos. Uma participante, a Beth, logo se prontificou e leu o seguinte:

"Foi um sonho rápido ou eu que não lembro muito dele. Vou escrever o que eu acho que aconteceu, mas não duvido que eu esteja "inventando" um pouco. Meu pai estava em um quarto, branco, como se fosse um escritório, sentado de costas para mim em uma cadeira. Na frente dele tinha um computador e ele estava falando no telefone, na verdade, ele estava gritando exingando (como se estivesse estressado) - ele costuma fazer isso na vida real. Eu fiquei irritado com a situação, do tipo, “não aguentava mais” e resolvi atacar ele com uma tesoura, dessas de metal, pontiaguda. Não 
consegui, ele desviou ou sumiu, sei lá, só que eu comecei a chorar como se em desespero, tanto pelo estresse da situação quanto pelo fato de eu ter tentado matar meu pai a tesouradas. Acordei bem assustado".

Assim que a leitura chegou ao fim, nós já sabíamos que o sonho era do Leonardo, pois o participante falara a respeito da dificuldade em saber se de fato foi um sonho ou uma invenção no momento de escrever o relato. Além disso, percebemos uma leve tensão no grupo, ocasionada pelo o próprio conteúdo do sonho. Inclusive, ao final do encontro, muitos comentaram da coragem do Leonardo em escrever esse sonho, que foi considerado bem forte.

Alguns dos comentários relacionados ao sonho foram: "me senti triste", "tesoura como cortar laço com o pai”, "atacar pelas costas é mais fácil porque não olha no olho e porque o outro se encontra indefeso", "surpresa de uma agressão sem muita justificativa”, "necessidade de sentir que está atacando (precisa ser tesoura, faca, não um revólver, que é distante), "incômodo/susto do sonhador", "sonho traz sensação de muita raiva".

O Leonardo mencionou que o fato de a tesoura ser pontiaguda o impressionara, pois ele tem algumas referências de tesouras como a do sonho, mas não costuma usá-las em seu cotidiano.

De um modo geral, o grupo se mostrou disponível e acolhedor. Eles estavam entusiasmados, mas respeitaram o momento de se expor e o momento de deixar que outro participante tivesse sua vez.

Um dos participantes que fechou o papel do sonho (para não ser lido) quis abri-lo no final, após a discussão do sonho. Outro participante também tomou a mesma decisão após o movimento do primeiro.

Ao final do encontro, ressaltei a importância da pontualidade e participação, além do sigilo e do fato de que não identificaríamos nenhum participante na pesquisa. Combinamos que não falassem sobre o que acontece no grupo fora dele, nem mesmo com os demais participantes, para que pudéssemos validar o processo do que ocorre quando estão todos unidos uma vez por semana na sala Ateliê. Além disso, foram assinados os Termos de Consentimento Livre e Esclarecido e avisados que os resultados da pesquisa seriam disponibilizados após sua conclusão. Uma das participantes era menor de idade e levou o termo para seus responsáveis assinar, e então combinamos que ela me entregaria no próximo encontro. 
No primeiro encontro foi compartilhado um sonho, sendo que os demais sonhos (ANEXO D) não são de conhecimento do grupo.

Em relação à temática dos sonhos apresentados, é curioso notar que alguns sonhos apresentam situações parecidas e recorrentes, expressas no ambiente onírico na forma de incertezas, nebulosidades, separações e a vivência de medo, raiva, solidão, irritação. Em alguns, se apresenta uma iminente e nova jornada.

Há quatro sonhos que foram resgatados da infância e trazem situações de inconstâncias, incertezas, e o medo e a dor decorrentes da imprevisibilidade e da impossibilidade de controlar o que é desconhecido. Estes temas podem ser relacionados ao momento em que vivem, já que todo início traz em sua raiz muitas dúvidas, apreensões e medo.

Três sonhos se passaram na própria faculdade. Neles há a experimentação de morrer e vivenciar uma nova experiência, a lembrança de uma cena de separação que provoca um choro profundo e a possibilidade de direcionar a mãe até a faculdade, para que nela a sonhadora possa encontrar novos e antigos amigos que se preparam para uma aventura juntos. De uma forma geral, é possível notar uma mudança importante, uma passagem de uma situação conhecida para uma totalmente nova.

Também é interessante observar a presença de água em muitos sonhos, em forma de um lago, chuva, a iminência de um temporal, enquanto uma fonte e representada através do choro, nos remetendo à operação alquímica solutio.

Além disso, também é curioso perceber a recorrência de tentar atacar, desejar cortar e de fato esfaquear um personagem no sonho. De alguma forma, parece haver uma tentativa de ataque, ruptura e experimentação de uma nova postura, indicando talvez a necessidade de uma atitude assertiva, de assumir os desejos e as próprias vontades.

\section{Contribuições do Registro do Encontro}

Ao final do primeiro encontro, foi solicitado que cada participante escrevesse em um pequeno pedaço de papel em branco três palavras sobre o encontro (ANEXO C). Através da análise das três palavras escritas no final do $1^{\circ}$ encontro foi possível notar certos agrupamentos de palavras que no geral mostram este foi marcado por interesse e curiosidade em um clima de relaxamento, tranquilidade e acolhimento, mas também estiveram presentes 
descrenças e receios, o que se pode considerar natural, visto que era o momento inicial do grupo.

O grupo de palavras formado por: exposição, inserção, interesse, curiosidade, abertura, entrega, confiança, indicam atitudes positivas no início de um grupo, visto que são fundamentais para que o mesmo possa se manter e desenvolver.

Outro grupo de palavras foi composto por: perspectivas, discussão e debate, reflexão, autoconhecimento e produtivo, o que pode ser entendido como um movimento inicial ainda estruturado na busca da assimilação intelectual a respeito do grupo, este enquanto lugar ou configuração da qual se pode extrair conhecimento ao ser investigado.

Por outro lado, vemos um grupo de palavras expresso por: obstrução, receio, descrença, desconfortável, guerra, esquisito e diferente, indicando que pode ser válido entender esta contradição como constituinte natural do processo de formação de um grupo, como uma etapa necessária para a construção do mesmo, ou seja, é preciso o embate com o novo, com o diferente e neste processo há desconforto e receio, mostrando resistência a ser lidada. 


\section{SEGUNDO ENCONTRO: DEFININDO CONTORNOS}

Quando, logo no início, formamos a roda e conversamos sobre o último encontro e a semana transcorrida, pude notar que o nosso primeiro encontro ficara neles ressoando. De modo geral, relataram que passaram a prestar mais atenção aos sonhos, ou a se relacionar com eles de uma forma diferente. Alguns também relataram dificuldade e dúvida em relação ao que é sonho e ao que é inventado após ter acordado do sonho e mesmo em saber de fato aconteceu algo ou se era uma realidade do próprio sonho. Provavelmente, esta dificuldade pode estar relacionada às diferenças entre o ego onírico e o ego vígil, daí o não reconhecimento de pensamentos e atitudes, que como visto, surgem de forma compensatória à ação da consciência.

Seguem alguns de seus comentários:

"Fiquei animada para vir hoje e ver o sonho dos outros e o meu. Sonhei na santa paz nessa semana, fazia muito tempo que não sonhava assim (sem ser tipo um jogo de videogame)".

"Lembro dos espaços dos meus sonhos, o que tinha ao meu redor".

"Não consigo lembrar dos meus sonhos como sonhos, só como realidades".

"Tenho dificuldade de entrar em contato com meus sonhos ou reviver os sentimentos que vêm do sonho. Sonhei essa semana, lembrava antes de acordar, depois esquecia. Lembrei de um na sexta, quando dormi de tarde".

"Lembrei que talvez seja importante eu falar que tenho terror noturno. Acho que quando estou sob estresse. É sempre o mesmo tema. Você acorda, mas seu corpo não".

"Fiquei pensando muito no meu sonho essa semana e me esforçando para lembrar de outro, consegui lembrar de um".

Em relação ao grupo, demonstraram muita vontade de compartilhar e ouvir mais dos colegas, ficaram interessados no modo como o sonho fora reverberando no restante do grupo. Uma das integrantes chegou a sonhar com pessoas do grupo. Alguns comentam que se impressionaram com a coragem de Leonardo, que teve seu sonho lido no primeiro encontro. Por ter compartilhado um sonho forte, abriu um caminho para que o restante do grupo pudesse também se entregar e explorar sonhos considerados mais intensos.

"Discutimos um sonho só, mas foi profundo". 
"Legal o sonho do Leonardo. Estava animada para vir hoje".

"Legal o Leonardo ter dividido um sonho tão forte, me motivou a querer lembrar do meu”.

"Foi um sonho marcante, foi bom entender um pouco mais sobre tudo isso, gostei. Gostei de ver como a leitura do meu sonho afetou os outros. Interessante se enxergar no sonho do outro".

Quando retomamos a leitura do sonho escrito no primeiro encontro, percebemos que foi uma atividade que os motivou a refletir sobre o mesmo. Houve uma iniciativa para entender o sonho e buscar uma análise, ou mesmo vê-lo por um ponto de vista diferente, como se alguém o contasse. Um deles percebeu um potencial na escrita enquanto resgate da emoção.

"Estranho ler o sonho agora. É bom. Parece que alguém está te contando o sonho, uma terceira pessoa".

"Usei palavras que eu não usaria normalmente, tipo escrevi "meu quarto" repetidas vezes, percebi assim como ele era importante”.

"Escrevi de forma bruta, tal qual foi o meu sonho (conteúdo bruto). Resgatei a emoção do sonho".

Após o relaxamento, conversamos sobre as sensações e sentimentos trazidos por ele.

"Ele (o sonho) veio muito forte, voltaram as imagens, a música faz uma diferença muito grande. Veio espontaneamente, ele é bem recente".

"Eu comecei pensando no sonho que eu tinha escrito na última aula, mas eu comecei, acho que até por conta de como eu estava me sentindo e eu estava pensando sobre algumas pessoas aí eu trouxe um sonho que se encaixava muito bem com o que eu estava pensando e sentindo e eu nem lembrava mais dele".

"Eu queria lembrar de um sonho meio novo que eu tive, mas eu não sabia se eu ia conseguir, aí no relaxamento eu fiquei com uma imagem muito forte na minha cabeça desse sonho louco, a imagem que eu desenhei, foi só essa imagem mesmo que ficou”.

"Eu achei estranho porque no meu sonho o que mais me incomoda não é a imagem que vem na minha cabeça, eu tenho noção de que esse sonho me incomoda tanto, mas quando penso nele a mesma imagem que eu desenhei não é tão significativo assim, pode ser significativo na historinha, mas não na forma como eu me sinto sobre isso".

"Durante o relaxamento acabei dormindo um pouco... só que foi interessante porque a forma como acordei se relacionou ao sonho que eu queria trazer, que foi o mesmo da última aula". 
"Eu escrevi o sonho hoje, mas ele me marcou porque é um sonho muito antigo, faz uns 4, 5 anos. E eu acordei muito mal. Senti uma sensação no tórax, me puxando para baixo”.

"Eu me senti meio pesado, não necessariamente ruim, foi um pesado de relaxamento, de me soltar".

"Achei engraçado que quando eu tive o sonho eu acordei de um jeito muito diferente do que quando eu pensei nele de novo, mas quando eu pensei eu lembrei da sensação e pensei que bom que não é mais assim”.

Outros e inesperados sonhos foram relembrados pelos participantes no momento do relaxamento, o que foi uma surpresa para alguns. Então, perguntei sobre o interesse de ficarem nos mesmos sonhos ou irem trazendo outros, à medida que os encontros prosseguissem. A maioria preferiu adicionar sonhos, procurei deixar claro que cada um podia escolher o sonho que quisesse para trabalhar no encontro. Apenas pedi para que aqueles que optassem por trazer novos sonhos os escrevessem num papel e me entregassem para ter o registro por escrito do mesmo, e três participantes o fizeram.

No momento do relaxamento, percebemos uma leve tensão nos participantes, talvez originada pela proximidade física dos corpos um do outro, talvez pela expectativa dos conteúdos que poderiam despertar na atividade. Ter percebido essa possível tensão nos tranquilizou, a mim e a colaboradora, quanto a uma dúvida inicial sobre o grupo em geral saber se abrir e fechar em relação à intimidade individual, preservando os participantes. No nosso entender, essa tensão poderia se relacionar com uma forma de saber se conter, retroceder e colocar os limites quando necessário.

Terminados o relaxamento e o desenhar, contemplamos um pouco cada um dos desenhos, observando e ressoando às imagens. Então, seguimos para um momento de compartilhar a escolha do desenho, em que cada um foi apontando para aquilo que mais lhe chamara a atenção. Foi escolhido o desenho da Ana Maria, que havia falado da dificuldade de representar o sonho em imagem, quando conversávamos sobre o que acharam do desenho. A maioria do grupo se interessou por ele porque o desenho traz uma imagem que eles consideraram difusa, que parece "bem sonho", sem contornos e na perspectiva do sonhador. Uma das participantes viu outra imagem no desenho e identificou uma pessoa ao invés de um urso. A própria sonhadora disse que não conseguira dar contornos. Abaixo estão o desenho e o sonho transcrito. 
Figura 1: Atende!

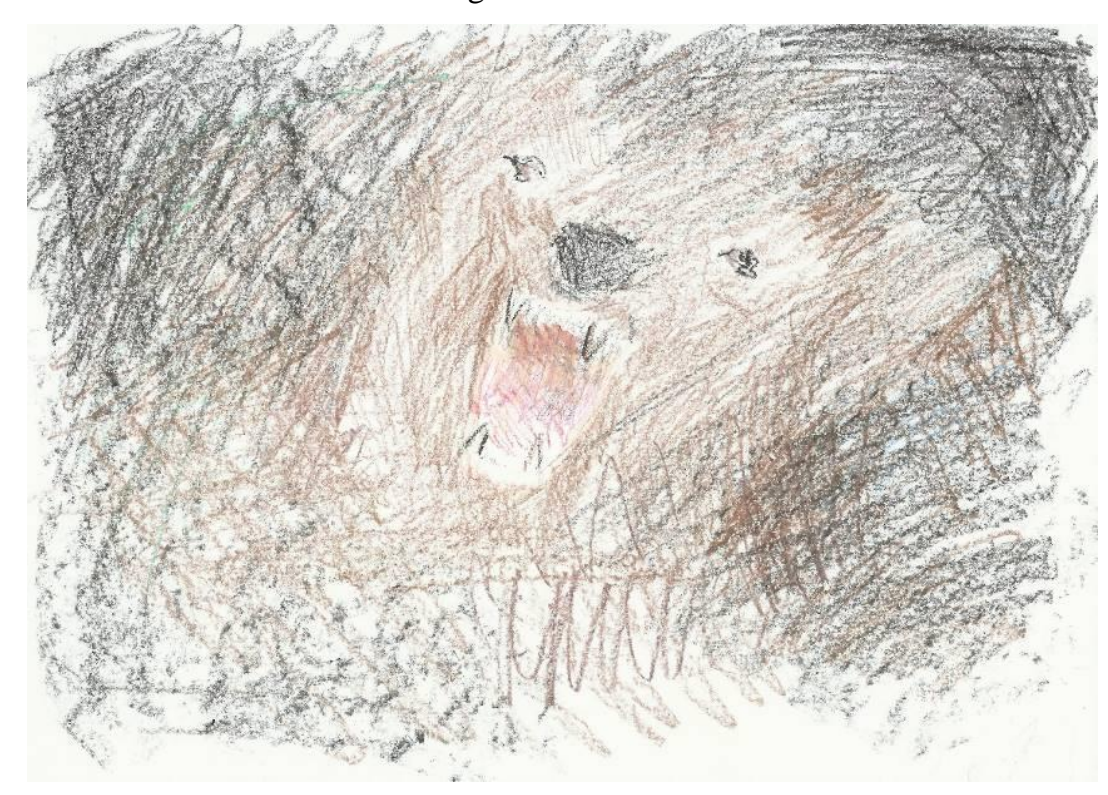

"O meu sonho era como se fosse... era parecido como tem aqui, duas avenidas e no meio tem um canteiro, só que ele era bem largo e algumas árvores espaçadas e como se fosse uma toca aqui no meio, uma oca, onde tinha um urso, aí tava minha mãe e meu namorado aqui e eu tava com eles, eu, sei lá, tava perdida aqui no meio e eu resolvi entrar nessa toca, eu sabia que tinha um urso lá, era como se, gente é bizarro, desculpa, era como se fosse assim um joguinho RPG, sabe, se eu entrasse na toca e eu passasse de uma certa distância eu não ia conseguir voltar e o urso ia me pegar, mas eu queria testar essa distância, por algum motivo, eu queria, sei lá, chegar mais longe que eu conseguia e poder voltar. E sei lá, eu entrava e tentava e não conseguia. Eu andava até uma parte aí eu já não conseguia, por algum motivo não conseguia mais voltar e o urso me pegava, mas sei lá, era como se fosse um videogame mesmo porque eu lutava contra ele e tal, mas não dava adrenalina, eu sabia que estava me machucando mas era como assim, não estivesse sentindo nada, mas enfim, eu fiz isso uma vez, eu fiz isso duas vezes e chegou uma hora que eu queria ajuda porque eu não conseguia voltar e apesar de eu não estar me machucando, é meio desconfortável você estar lutando contra um urso (risos). Aí eu sei lá, chamava minha mãe e meu namorado e eles estavam conversando ali fora e nenhum deles me olhavam e eu ficava muito " $P$ " da vida porque sei lá, eu queria uma ajuda e enfim uma hora que o urso terminou de me atacar, eu tentava de novo, até que uma hora eu queria ajuda, daí tipo não tinha resposta, tanto é que o nome que eu dei foi Atende! Pelo amor de Deus, me ajuda aqui por favor? E é isso".

Após o momento em que a Ana Maria contou seu sonho, abrimos para a discussão, e os demais começaram a falar sobre o que sentiram, o que pensaram e de que forma o sonho os afetou. A sonhadora comentou da dificuldade que sentiu para colocá-lo em uma imagem, e que para ela seria melhor dizer uma palavra que expressasse um sentimento. Outros participantes concordaram e se identificaram com ela. 
"Eu acho que você falou de representar um sentimento, mas veio a imagem do urso que te passa o que você está sentindo. Acho que isso foi uma dificuldade minha quando eu estava desenhando também. Um dos motivos por eu não ter escolhido o sonho que eu escrevi foi porque para mim, eu não consegui nem escrever ele, quanto mais desenhar, concretizar".

"Para mim também foi dificil. O sentimento foi maior que a imagem e na hora de desenhar eu até meio que tentei unir, desenhar algumas coisas a mais para tentar transmitir mais o sentimento".

"Eu achei um sonho bem interessante e pelo que ela descreveu todas as situações convergem pra esse sentimento e ela mesma falou que pra ela é mais representativo pra ela um sentimento do que uma imagem no caso desse sonho, nem todos sonhos são assim, tem uns que a gente não consegue traduzir um sentimento e a gente fica com a imagem e acho que isso de ela querer ir várias vezes no urso parece que ela tá, parece que é pra ela chegar naquele final, pra que essa situação aconteça. Sei lá, não sei como funciona o sonho, como que é a formação de um sonho, o inconsciente, sei lá, mas assim me deu a sensação de que esse sonho especificamente dela parece que primeiro você tinha a ideia, aquele sentimento, aí você tinha que criar uma coisa em volta porque ele faz mais sentido pra mim visto em retrospectiva do que ela contando desde o começo, a partir do fim, entendeu? Tipo, pensar assim: eu sou o Inconsciente da Ana Maria (risos do grupo) o que eu teria que colocar ali, com os elementos de trás pra frente pra ela chegar naquilo. Não sei explicar melhor que isso".

Em relação ao sentimento suscitado pelo sonho, a sonhadora disse: "o que mais me incomoda nesse sonho é chamar minha mãe e meu namorado e eles não me responderem, é meio que uma decepção, mas o urso é a primeira figura que me vem à mente, mesmo sendo uma coisa completamente mecânica..." e outro participante disse que o incomodaria mais ser atacado pelo urso, porém para a sonhadora, o sonho a incomodava pelo fato de ter pedido ajuda e, apesar de a mãe e o namorado estarem perto, eles não a notarem.

Em seguida, passamos para uma discussão sobre o simbolismo do urso, que se desdobrou até uma questão sobre a realidade e a virtualidade, sobre as ameaças reais e as de "mentirinha".

- "Tem algum símbolo pra você o urso?"

- "É tipo que nem a tesoura pontiaguda (referindo-se ao símbolo do sonho do primeiro encontro). Era secundário o fato de ver que bicho era, mas era muito claramente um urso. A imagem dele, uma coisa grande, peluda e marrom que ia me atacar, me matar. Não, mentira, ele não ia me matar, eu sabia disso. Era bem um sentimento de estar jogando um RPG, você quer chegar ali, sabe que vai se ferrar, mas não tem tanta importância assim”.

- "Se você morrer no RPG, você não morre na sua vida, você morre no RPG só". 
- "Mas não era como estar jogando, era como estar vivendo".

- "É estranho, eu já tive alguns sonhos assim também. É bem que nem RPG, um treco meio estranho. Ao mesmo tempo que você quer buscar, uma coisa meio aventura, você sabe que é meio perigoso, mas você tem meio consciência de que você não tá correndo um perigo de verdade. Então você só vê meio que uma aventura lá esperando você, ela tá lá, você só... é o que o João falou: como se tudo o que você estivesse sonhando, tivesse te levando pra você ter aquela situação, pode acabar em frustração, pode acabar mal, pode sei lá, de todo jeito acaba que você tenha que, pelo menos comigo acontece assim, você tem um sentimento meio de sei lá, realização pós”.

Questiono sobre o fato de testar limites, verificar até onde se pode ir e chegar e a sonhadora disse que lembrou, após eu ter mencionado, que, no começo do sonho ela estava testando.

Ainda em relação ao processo de dar contornos e limites, foi interessante observar que o Cristóvão comentou que no desenho colocou muita forma e contorno, e assim percebeu aspectos que não tinha percebido antes, o que foi bom, pois o conteúdo mexeu com ele.

Também comentaram da força com que os cenários e espaços ao redor se apresentaram nos sonhos, sendo que exploraram bastante este aspecto nos desenhos. Além disso, é importante dizer que procuraram esboçar uma tentativa de conceituar os sonhos, iniciaram algumas elucubrações a respeito dos sentidos e do modo como são estruturados, procurando uma arquitetura do sonho.

Neste momento, já havíamos passado do horário e ainda faltava entregar as questões sobre o encontro. O sonho da Ana Maria constelou um forte sentido de grupo, uma vez que foi perceptível a mobilização com o tema do sonho, demonstraram interesse e acolheram bem o conteúdo e a sonhadora, demonstrando também muita vontade de ouvir, fazer perguntas e propor observações e análises.

No final do encontro, a Laura perguntou se podia trazer outro sonho, pois gostaria de desafogar dos confins da sua cabeça. Foi interessante a sua colocação, nestes termos, e para o grupo. Foi possível identificar uma progressão do grupo em desenvolver um vínculo de confiança e acolhimento. O grupo tornou-se um espaço em que ela poderia desafogar dos confins da sua cabeça, aludindo à possibilidade de ampliar os limites.

Tive muita vontade de colocar mais "lenha na fogueira", principalmente em relação aos temas de definição de contorno, limites, de dar vazão a algo no grupo, se entregar, mas com o risco de saber até que ponto poderiam ir. Sobre o conteúdo do sonho em si, parece que 
existe um perigo em estar sozinha e ter que dar conta da situação sem ajuda, enredo que em si mostra um aspecto do amadurecimento, da entrada na vida adulta, e arcar com as consequências das próprias escolhas, juntamente com o experimentar a frustração e irritação decorrentes de ver-se só.

Terminei o encontro enfatizando para que nos procurassem caso sentissem algum desconforto e pontuei novamente a questão do sigilo e acolhimento. Sugeri que fizessem um diário caso sentissem necessidade, como uma forma de continência e registro das emoções evocadas pelos sonhos. Pedi para escreverem por escrito o sonho do desenho, se fosse diferente do sonho do primeiro encontro e entreguei o Registro do encontro para preencherem. Assim, terminou o segundo encontro.

O sonho compartilhado no grupo trouxe em mim e na colaboradora uma lembrança dos rituais de passagem indígenas, em que os adolescentes são colocados em situações de perigo, sozinhos, isolados dos adultos da tribo e dos seus iguais, tendo que dar conta sozinhos da situação e passar por provas para assim poder entrar no mundo adulto. Poderia ser este um tema subjacente: passar por situações limites sem ajuda externa; iniciar a sua própria jornada do herói.

É muito importante ressaltar que o grupo, apesar de esboçar um movimento em conjunto, não é homogêneo. E, assim como no $1^{\circ}$ encontro, neste também senti uma certa tensão no final. Um dos participantes, que já havia mencionado da dificuldade em aceitar os sonhos, pareceu estar se contendo, como se houvesse muito a ser dito, mas uma dificuldade maior impedia, como se houve muito conteúdo explodindo dentro dele, mas com uma dificuldade para expressá-los. A sonhadora também parecia tensa, como se estivesse contendo algo não processado, mas após a atividade de desenhar e compartilhar, parece ter conseguido expressar algo, organizando um pouco esse possível conteúdo antes não digerido.

Os desenhos realizados encontram-se no ANEXO F. É interessante notar certos elementos que vão se repetindo e entrelaçando, realçando certas regularidades nos desenhos. Entre elas podemos perceber que a maioria dos desenhos traz uma cena em que existe: solidão e desamparo; situações de vulnerabilidade, risco e instabilidade; perigo e ameaça, mas também enfrentamento, conflito ou dificuldade. De alguma forma existe um estar sozinho enfrentando ou tentando enfrentar, um ter-se a ver com a necessidade de ultrapassar a sensação de desamparo e desenvolver autonomia própria, encontrando em si recursos para 
lidar com os desafios e dificuldades, o que pode também ser associado ao ingresso na faculdade.

Também é possível observar temas em que se está preso ou há imobilidade. Há uma predominância de objetos quadrados ou retangulares. Em um deles existem pessoas presas dentro de uma caixa e no outro, uma menina sozinha e pequena andando por entre 3 caixas enormes.

Em dois desenhos, existe um chamado, um pedido subjacente: "Atende!" e "Please, open the door!'e em outro desenho, há uma menina parada em frente à uma porta fechada.

Também é visível a representação de meios de transporte ou objetos que representem a travessia, porém o barco está ancorado e o carro não está na estrada. Há uma bala de revólver ou algum outro objeto que está perfurando, atravessando. O tema de atravessar também se repete no desenho em que existe uma ponte, mas atravessá-la parece perigosa.

Em outro desenho há o confronto com uma máscara e encará-la revela-se doloroso.

Por outro lado, também há a presença do elemento fogo, ele aparece na fogueira, na lava que fica abaixo da ponte e na bala de revólver, cujo título é “Quente e Raiva”. Assim, como o fogo, no desenho intitulado "Sopro" é perceptível muito vento, muita movimentação e há uma torre de pessoas em que há uma instabilidade, ou seja, ela pode cair em algum momento.

Aprofundando o tema do fogo e do ar, podemos ver que juntamente com o risco, a solidão e o perigo, mostram-se elementos de muita força, energia e movimento, como o ar e o fogo.

\section{Contribuições do Registro do Encontro}

Novamente, foram solicitadas três palavras que resumissem o encontro e que respondessem aos seguintes aspectos:

\section{Este encontro, em três palavras, foi...}

Do $1^{\circ}$ encontro para o $2^{\circ}$ encontro foi possível notar certas alterações bastante interessantes. Parecem adotar postura mais ativa, inferida a partir das palavras mencionadas: viagem, tentativa, estimulante, explorar, re-experimentar, concepção. 
A questão não é o desconforto aparecer, mas como se lida com ele. receio, dúvida, conflito, pesado, incômodo, sangue, frieza, complexo, difícil, esforço, paciência, atenção, mas esta dificuldade parece não se revelar como obstrução e descrença, palavras que apareceram no $1^{\mathrm{o}}$ encontro, levando-nos a pensar que estão sendo abertas vias de comunicação e expressão dos mesmos.

O grupo de palavras composto por permanente, calma, zen, tranquilo, lembrança, bom, esclarecedor, calor, reflexivo, divertido, surpreendente, relaxante, imersão, abertura, imagética parece revelar que o contexto grupal está se desenvolvendo enquanto continente do processo de elaboração simbólica do grupo, motivando a pensar que está habitado por Héstia.

Entende-se que estão buscando definir os próprios contornos individuais, mas também em relação ao grupo, conteúdo e forma se entrelaçam no processo de elaboração simbólica.

\section{Experimentar meu sonho a partir dessa atividade...}

Comentaram que a atividade do relaxamento foi capaz de despertar várias emoções, sendo que algumas foram consideradas perturbadoras, fortes, e outras conseguiram ser extravasadas no desenho. Foi muito comentada a dificuldade de expressar em uma imagem do sonho o sentimento subjacente a ele, porém, de certa forma essa dificuldade constitui-se enquanto um desafio que permitiu reflexões e relações até então inéditas.

Também mencionaram o caráter de novidade da atividade de desenhar, avaliando-a como diferente, estimulante, legal, divertida, e desafiadora, que permitiu buscar meios visuais para representar sentimentos subjetivos, tornando possível uma nova perspectiva sobre o sonho, com outros aspectos e trazendo uma imagem mais nítida.

\section{O que levo daqui...}

Os participantes saíram do encontro mencionando levar com eles um convite à reflexão e imersão no sonho e considerando a busca pelo simbolismo no sonho, além de perguntas e pistas de entendimento sobre os sonhos, como a aquisição de uma nova perspectiva sobre os mesmos.

Relataram sentir vontade de voltar, curiosidade e motivação para os próximos encontros e comentaram acerca das diferenças, que são vistas como interessantes, e parecem representar um encontro com novas formas de assimilação e interpretação, culminando na possibilidade de se viver uma experiência nova e única. 
Também esboçaram comentários iniciais a respeito da constituição do grupo, pois mencionaram levar consigo o sonho de uma colega e seus sentimentos, um pouco mais de conhecimento dos demais participantes e a descoberta de que existem facetas desconhecidas em si e nos outros, e também começa a tomar forma a sensação de viver uma experiência única de compartilhamento, valendo-se da comunhão de opiniões.

\section{O que deixo aqui...}

Começam a deixar um pouco de si mesmos, seja na presença, nas impressões, ideias, relatos e imagens dos sonhos, seja nos sentimentos, de medo, apreensão, incômodo, insegurança. Um dos participantes mencionou que, ao desenhar, o medo e apreensão tomou forma e contorno e assim, "saíram dele", mostrando uma primeira etapa de elaboração simbólica. Outro disse que deixa o excesso de atenção ao meu racional, evidenciando que uma nova forma de percepção está em curso, trazendo a participação da emoção.

Um participante diz que deixou menos do que gostaria de ter deixado e outro que ficou inseguro e com medo de lembrar um sonho, momentos que também são muito importantes de serem compreendidos e acolhidos, nos levando a pensar numa resistência criativa, a serviço da proteção do ego.

Também comentaram que deixam uma vivência íntima, mas de certa forma coletiva, que agora podem dividir o sentimento do sonho e também oferecer reflexões e motivações para outros colegas, sugerindo um incipiente self grupal. 


\section{TERCEIRO ENCONTRO: VAZÃO À EMOÇÃO.}

Ao término do segundo encontro e após a leitura das respostas dadas ao Registro do encontro (ANEXO E) percebemos a motivação do grupo em se expressar e ouvir sobre o sonho dos demais e considerei imprescindível uma atividade em que pudessem ter mais tempo entre si, compartilhando seus sonhos de uma forma mais ampla, com a participação pessoal de todos no processo de expor, analisar e também ouvir e acolher.

Sendo assim optamos pelo contar sonhos. Em pares, uma atividade que se revelou eficaz e proveitosa para a experiência de alteridade e aprofundamento de vínculo entre os pares e entre o grupo.

O terceiro encontro foi iniciado pela conversa em roda habitual, a respeito do encontro anterior, dos sonhos, e do desenrolar da semana. Neste momento, a colaboradora expôs uma observação importante em relação à abertura e disponibilidade do grupo para as atividades propostas: "sinto o quanto vocês estão abertos, entregues, não é todo grupo que é assim". De fato, o grupo se mostrava bastante participativo e entusiasmado e no terceiro encontro não foi diferente.

Sobre o relaxamento, foi possível observar que a maioria o aproveitou bem, sendo que alguns se entregaram de tal forma que chegaram a adormecer. Muitos comentaram que há muito tempo não se sentiam tão relaxados e que estavam bem melhores agora, após o trauma do cursinho.

"O relaxamento foi super efetivo para mim, mas não me deu sono, me deixou bem relaxado, bem assim fora dessas coisas cotidianas, bem livre, assim, sei lá, para divagar”.

"Sabe quando você sente a mente em branco, eu me senti muito assim e eu gostei bastante".

"Acho que fazia muito tempo que eu não me desligava assim de tudo para ter um tempinho só para não fazer nada".

"Parecia que a minha cabeça não estava aqui, ela simplesmente foi para lugares que eu nem lembro, só sei que na hora que você falou: "Agora, vamos abrir os olhos”, parecia que eu tinha saído de um lugar e voltado para a realidade".

"Fazia um tempo que eu não fazia nenhuma atividade desse jeito e [...] é bom para mim, sentir o meu corpo mais relaxado". 
Dois participantes comentaram que a atividade alterou a maneira como se relacionaram com o sonho e o impacto que o relaxamento teve na atividade de desenho a seguir:

"Achei bem interessante porque essa forma fez com que eu lembrasse muito mais do sonho do que se eu estivesse acordada por exemplo, ou escrevendo ele, deu para vivenciar muito mais dessa forma".

"Achei bem legal o negócio do relaxamento, tanto que eu estava na cabeça com esse sonho que eu tinha escrito, para desenhar o mesmo, mas quando começou o relaxamento por algum motivo minha cabeça mudou para outro completamente diferente e nem foi racional isso".

Pela primeira vez, foi comentado do grupo e não apenas dos sonhos que estávamos investigando, sugerindo que o grupo estava num processo de formação e os sonhos vieram como fator de ligação comum entre os participantes em torno da experiência de entrada no curso de graduação em Psicologia.

"Acho que essa atividade para a gente, não interpretar, mas conversar um pouco sobre o sonho do grupo, do processo do grupo, é uma experiência muito legal. É bem gostoso".

"Acho que como a gente entrou nesse grupo logo no começo da graduação, muito no começo mesmo, cada semana que passa faz uma diferença substancial no tanto que a gente se conhece. É interessante isso aqui. Em uma semana é uma diferença o tanto que a gente se conhece porque a gente entrou aqui praticamente não se conhecendo, foi na $2^{a}$ semana de aula já. Então isso é uma coisa legal de se notar [...] Parece que os sonhos vão mudando com a interpretação que a gente vai dando em relação a eles porque a gente vai conhecendo melhor as pessoas que sonham, os sonhadores [...] eu sonhei com uma coisa relacionada com o grupo pela primeira vez".

"Gostei muito do que o Heitor falou sobre se conhecer melhor porque uma coisa que eu posso falar assim mais sobre mim é que apesar de eu falar pra caramba, vocês perceberam, eu sou uma pessoa tipo meio assim para falar coisa importante para as pessoas e eu estou me sentindo assim mais a vontade de falar esse tipo de coisa que eu estou falando assim agora. Acho que é uma coisa muito legal porque a gente está se consolidando como grupo tipo aqui e um grupo de "migos" no geral, acho da hora".

A maioria comentou que sonhou durante a semana, mas os sonhos acabaram esquecidos, seja no momento de despertar, seja ao longo do dia. Alguns comentaram que houve uma importância dada ao conteúdo, seguida de um pensamento para anotá-lo, porém, devido a diversas tarefas, acabaram deixando para outro momento e nesse ínterim se 
esqueceram. Outros já começaram a perceber certos padrões nos sonhos e a se relacionar com eles de uma maneira mais consciente, atribuindo certos sentidos e lógicas próprias.

"Essa semana eu sonhei várias coisas também e foram sonhos parecidos no sentimento que eu tive em todos eles, e pelo fato de eu de estar correndo perigo durante o sonho, mas não eram pesadelos, mas eu estava correndo perigo no suspense".

"E essa semana eu sonhei bastante e eu voltei a ter padrões de sonhos que eu já tinha antes, eu não sei se é por circunstâncias que aconteceram na minha vida, mas eu estou voltando a ter sonhos que eu já tinha antes. Eles estão se repetindo”.

"O único sonho que eu lembro é o que eu tive essa noite, acho que não por proximidade, mas porque foi diferente, foi nervoso".

"E eu tive alguns sonhos essa semana que foram mais relacionados com coisas que eu estava pensando, eu fiquei pensando muito numa situação em casa, então eu fui e sonhei aquilo".

Também relataram a dificuldade acerca da experiência de desenhar um aspecto do sonho, e de não conseguir passar a sensação para uma imagem, seja por uma questão artística, seja por uma questão emocional. Alguns recorreram à representação de um sentimento como alternativa à dificuldade que a representação gráfica trouxe.

"Eu achei muito dificil desenhar meu sonho porque apesar de ser uma imagem muito clara, eu tinha tipo uma imagem, mas eu não conseguia passar no meu desenho a mesma sensação que eu tinha quando eu pensava nessa imagem, tipo eu não conseguia de jeito nenhum, talvez seja porque eu não sei desenhar (risos). Mas eu não consigo passar o mesmo clima no desenho do que eu estava pensando, mas eu achei bem legal de tipo tirar isso e colocar no papel de uma forma diferente, não só escrevendo".

"Eu também tive dificuldade para desenhar o meu sonho, eu acho que por ser um sonho que eu não conseguia nem escrever ele direito, então acho que desenhar foi um pouco pior porque se resume muito a um sentimento, tanto que eu mudei de sonho na hora de desenhar".

"Como eu não tenho tanta capacidade artística assim eu tentei expressar mais sentimento, emoção, e eu acho que acabou tendo mais impacto em mim a parte de escrever, estou mais acostumado com isso, mas eu gostei, foi legal".

"Eu gostei mais de desenhar o sonho do que escrever, acho que escrever é uma coisa que fica meio mecânica, você fica procurando palavras, e quando você está desenhando você está passando o lápis... não tinha como apagar, não tinha como mudar o que eu tinha... era meio que definitivo, mais crua, mais direta a representação do sentimento". 
"Você não vai escolher as palavras, você só, sei lá, pega uma cor que tem vontade de colocar ela aqui, parece que é uma coisa que flui mais para o papel do que usar as palavras".

Em seguida, como um aquecimento, fizemos a leitura de alguns parágrafos contendo breves explicações sintéticas e didáticas sobre a abordagem junguiana aos sonhos, extraídas de WOLFF (1981), e cada participante leu um parágrafo e passou a vez para o próximo participante sentado ao seu lado na roda.

Terminada a leitura, prosseguimos para a formação de duplas e início da atividade, durante a qual foi possível perceber muita empolgação e entusiasmo; eles contavam os sonhos sorridentes, se movimentavam bastante, gesticulavam, falavam alto e em alguns momentos riam.

A primeira dupla a relatar a experiência trouxe à tona a questão de sonhos assustadores e constrangedores, passíveis de julgamento pelo restante do grupo e a consequente dificuldade para lidar com esse material onírico.

"Até me relacionei um pouco porque o tipo de sonho dele é um sonho que as vezes também aparece muito para mim. Na primeira semana, isso aconteceu, foi um sonho, foi assim, digamos, um tema semelhante e eu não quis escrever porque sei lá, eu tive a impressão que alguém ia me julgar se eu lesse esse sonho e ai eu não quis fazer isso".

"Quando eu fiz o meu, eu também deixei ele fechado na primeira sessão porque eu achei que aconteceria algo do gênero também e eu fiquei surpreso também que é normal (muitos risos do grupo)”.

Conversamos então sobre as funções do sonho, e o que poderia ser uma função compensatória ou um aviso para os sonhadores, no sentido de um alarme e um apelo à consciência. Também comentamos que às vezes vem um conteúdo simbolicamente forte e quando isso ocorre nossa atenção se volta para aquilo que precisa ser trabalhado, assimilado e elaborado.

A dupla seguinte enfatizou o modo de sonhar ser diferente, que há pessoas que têm sonhos mais curtos e outras mais longos. Sonhos com enredos e muitos personagens e outros com cenas curtas e sintéticas.

"Os meus são sempre muito curtos e muito irônicos e tipo não tem uma história muito grande por trás e o do Heitor é super bonitinho”. 
"Ah mas agora eu vou em defesa dela. (Risos). Os sonhos dela podem ser curtos, mas são impactantes. [...] ela também tem muito mais consciência dentro do sonho [...] os meus sonhos são muito narrativos, são muito ligados em torno de enredo, personagens, diálogos e coisas assim, mas não é sempre que eu tenho essa sensação no sonho de estar controlando. Geralmente é a sensação de estar participando e assistindo e me envolvendo em um monte de coisa, mas não necessariamente controlando e agindo.

"É legal ver essas diferenças, foi bem rico".

Outra dupla comentou que escolheram sonhos de infância para compartilhar no grupo, também houve descoberta e identificação ao perceberem semelhanças nos sonhos.

"A gente contou dois sonhos que a gente também mudou o sonho final para desenhar e a gente teve uma ligação que foram sonhos repetitivos e foram sonhos de infância. E aí a gente meio que se identificou com isso de uma coisa que era, sei lá, tão atrás e aí você ainda consegue lembrar daquilo e aquilo ainda está tão presente em você e você não sabe o porquê exatamente. E contar, assim, de todas as formas, eu acho que contar é a mais legal, pelo menos foi a que eu mais gostei. Porque parece que você vai revivendo e aquilo é mais livre, é mais, parece que você está ali, na hora que você está contando parece que você está realmente no seu sonho e se vendo dentro dele”.

"Eu achei muito mais fácil contar do que escrever e desenhar. E essa parte de se identificar com o sonho dela achei bastante marcante porque até então achava que era só eu, eu contava para a família toda e ninguém tinha. Achei bastante interessante”.

A última dupla a compartilhar comenta a semelhança de cenário nos sonhos de ambos, no caso, o ambiente escolar, e também sobre a questão da emoção presente nos sonhos.

"Teve uma coisa em comum com nossos sonhos porque foram lugares que nós dois conhecíamos tipo o dela foi na escola dela, o meu foi aqui no $I P^{7}$ ".

"Achei que o legal do sonho dele é que a emoção que ele teve assim no sonho passou..., ele acordou e continuou sentindo aquilo, um alívio, [...] eu achei legal ver essa conexão entre o que estava acontecendo lá e com o que ele sentiu lá no sonho e o que ele sentiu quando acordou”.

De um modo geral, foi possível notar que falaram de forma positiva das diferenças entre os sonhos e as sensações que eles trazem, e também das semelhanças em relação à exposição, como ficar envergonhado, temer o julgamento e expor emoções fortes.

O Pedro prontamente se voluntariou para dizer o seu sonho, cujo relato verbal encontra-se transcrito abaixo:

\footnotetext{
${ }^{7}$ IP é uma denominação para a faculdade.
} 
"Meu sonho foi no IP. Foi muito rápido. A parte importante. O resto do enredo eu não lembro. E eu tava aqui no IP, com algumas pessoas da nossa sala, da minha sala, e aí a gente estava subindo uma escada e de repente na mente eu lembrei de uma, eu pensei, veio, algum estímulo me fez pensar na vida de um casal apaixonado, mas em um momento triste, uma coisa triste, uma tristeza inerente ao amor desse casal e aí eu pensei numa pessoa que eu conheço e eu chorei, eu chorei no sonho, na escada, chorei muito. Só que foi um choro restaurador, aliviador, de um sonho que eu estava carregando, no sonho e na vida real. Tipo o sonho é esse choro, eu estava ... eu queria chorar na verdade há um tempo, enfim, eu queria e não conseguia e aí no sonho aconteceu isso e aí no sonho eu me senti bem, me senti livre e quando eu acordei me sentia parecido, quer dizer, sentia a mesma coisa, como se eu tivesse chorado e sentia o alívio que eu imaginava que eu sentiria se eu chorasse e não durou, não foi como se tivesse acontecido de verdade, mas foi surtindo efeito, acordei com a sensação que estava no final do sonho, foi de felicidade, de leveza".

Após o relato, conversamos sobre a recepção do sonho pelos demais participantes, perguntei-lhes se estavam se sentindo tocados ou se já haviam tido sensação parecida. Logo no início um dos participantes achou interessante que o alívio emocional tenha ocorrido num sonho e que sua ação tenha atingido a "vida real" do sonhador.

Outra participante se interessou pela emoção do sonho, achou bonita a entrega do sonhador à pessoa que fora lembrada e o fizera chorar no sonho. Fomos nos aprofundando no sonho e falamos sobre a importância das associações do sonhador, da reflexão a respeito do papel que a pessoa desempenhou e/ou ainda desempenha para o sonhador, sobre a imagem do casal apaixonado e como ele se relaciona com esta atualmente e até mesmo sobre lidar com as emoções, sobre chorar, extravasar ou conter e guardar.

Foi o primeiro sonho que se passava na faculdade de psicologia. Outro participante também diz que isso o impressionara:

"Eu também já tive um sonho aqui e eu acho que, talvez a coisa mais comum entre todos nós é que todos nós passamos por uma entrada aqui, então eu acho normal pelo menos".

A seguir o sonhador prossegue:

"Eu não sei porque eu sonhei com o IP. (Todos riem). Eu não sei, mas talvez o negócio de eu ter chorado é, fiquei pensando se, é porque eu estava incomodado com essa questão, estava me segurando. E aí eu achava que eu estava muito triste, mas eu não dava vazão para isso, mesmo porque eu não conseguia pensar sobre isso, eu acho que eu não conseguia pensar sobre justamente porque era realmente uma coisa muito forte e eu estava com medo de chorar por ser uma coisa devastadora e aí eu fiquei, eu recalquei isso por muito tempo. E talvez eu tenha recalcado isso por 
tanto tempo que já não conseguia mais chorar mesmo, tipo eu recalquei para um lugar muito longe e a tristeza já era reconhecível, já não me identificava. Mas o mal-estar persistiu e aí acordado eu pensava 'Pô! Preciso dar vazão a isso', acho que eu preciso muito chorar e eu estava estranhado e aí no sonho eu não sei se eu realmente chorei porque eu fiquei triste ou se era porque era um sonho e eu podia chorar e eu me forcei a isso [...] No sonho é fácil, no sonho eu posso porque era uma coisa que eu queria fazer, era uma coisa que eu imaginava no sonho, imaginava acordado fazendo isso, uma forma de passagem desse assunto a limpo, de superação, que eu achava que ia ser o jeito de eu resolver isso mesmo, mas eu não, acordado eu não me sentia tão triste a ponto de chorar de verdade, por isso que eu ficava imaginando, assim, as vezes eu tentava forçar uma coisa que pudesse começar o choro para conseguir chorar sozinho e aí bom no sonho eu pude forçar, talvez eu pudesse ter forçado isso".

Em relação às associações, o sonhador disse que pensar na tristeza inerente ao amor é um jeito pelo qual ele enxerga o amor, como uma coisa necessariamente triste. Com a pessoa que aparece no sonho, ele comenta que perdeu o contato:

"A gente perdeu o contato porque a gente está fazendo um monte de coisa, quer dizer, cada um está com a sua vida, a gente não tem mais tempo para ficar junto. E a gente tem poucas oportunidades de se encontrar, então, sei lá, a gente gosta de conversar quando a gente se encontra, mas a gente não se encontra, (risos), mas enfim... a função, o papel que ela tem na minha vida hoje eu não sei, é outro papel. É um papel, de tipo... é um novo papel. Por um tempo foi um, durante outro tempo foi outro, mas já não é mais nenhum desses dois [...] ela já foi uma pessoa muito, muito importante na minha vida".

Comentamos que o sentimento dele ao falar da pessoa parecia nos atingir e ele comentou, brincando, que agora tinha dado vazão, mas que ainda assim se sentia surpreso, porque já não pensava muito sobre isso, sentia que já havia passado, e que apesar de o sonho ter trazido esse alívio, ele não conseguia vê-lo como tão importante.

Neste instante, uma participante o questionou, mostrando que mesmo que não aparecesse na superfície, poderia haver algum outro motivo que o tivesse levado a querer expressá-lo no grupo. Então, ele responde que teve a impressão de que foi mais marcante o alívio trazido pelo sonho e não a questão subjacente.

A seguir, um dos participantes comentou que se sentira tocado pelo fato de o choro trazer alívio, que isso evocara nele uma questão pessoal que ainda persistia.

"A forma de expressão que ele encontrou tem muito a ver comigo também, eu acredito. Eu acho que a questão do peso e do alívio, principalmente isso. De ter algo pesado que você vai 
guardando, guardando e guardando e aí depois você tem que aliviar de alguma forma e, no caso do sonho foi o choro e também, às vezes escondido, mas não necessariamente isso, é mais a questão de ter algo pesado que você precisa aliviar e, enfim, isso evocou coisas pesadas".

Após esse comentário, foi possível perceber que o sonho relatado mobilizara de uma forma mais ampla os demais participantes e fora além do conteúdo, atingindo o modo de elaborar e lidar com as emoções mais difíceis, o peso, que vai se formando quando se guarda conteúdos fortes e o alívio, que vem quando se consegue dar vazão às emoções.

Em seguida, procuramos enfatizar que buscar o alívio e dar vazão às emoções é muito importante e que o sonho pode auxiliar em momentos de conflitos e de emoções estagnadas e obstruídas ao trazê-las à superfície justamente para atingir a consciência e assim procurar compreensão e elaboração das mesmas.

Outros dois participantes também relataram sentir peso, mas outros não sentiram dessa forma, foi uma discussão bastante interessante sobre acumular e guardar emoções e dar vazão e alívio às mesmas.

Um dos participantes, que disse não ter se sentido pesado trouxe uma consideração bastante interessante:

"Eu senti uma coisa bem intensa, mas eu acho que eu não senti peso porque pra mim também é muito inerente essa ideia de tristeza vinculada ao amor e a outras coisas, só que pra mim é meio paradoxal e pensar sobre isso não é triste, é meio que, eu acho que mesmo se eu pudesse escolher pra ser de outra forma, eu não escolheria porque pra mim isso é importante, necessário, é vital até que eu acho que a plenitude do sentimento, alguma coisa assim, ela precisa de um drama ou de uma tristeza pra se concretizar. Eu sinto muito isso e eu não sei se eu sinto isso desde muito tempo, isso é uma coisa tão inerente que não me incomoda, o que me faz sentir peso é quando existe uma obstrução na expressão, quando alguma coisa não pode ser expressada, que existe alguma coisa travando, isso que dá a sensação de peso. Agora, tipo, qualquer expressão, seja ela, principalmente o choro, para mim é a expressão mais plena que pode existir, então toda vez que o final, o desfecho é um choro, não consigo sentir peso, acho que é sempre uma libertação, peso é sempre quando tem alguma coisa travada, alguma coisa que está ali aprisionada, que no final não consegue ser expressada".

O fato de um participante ter mencionado a respeito da presença contraditória e necessária de ambos levou a conversa para um entendimento de que conviver com essas polaridades é importante e necessário. 
Finalizando, perguntei como o sonhador Pedro estava se sentindo após compartilhar o sonho:

"Ah, eu estou me sentindo um pouco como me senti no sonho, a emoção voltou um pouco. Contar o sonho tornou ele muito mais relevante de novo, quer dizer, falei que ele não era muito importante, mas ele, o significado dele voltou a me fazer pensar sobre ele, me fez valorizar mais esse sonho. Acho que é bom porque eu talvez tivesse achado que isso já não tinha mais o que ser trabalhado, talvez achasse que isso já fosse passado, que eu não deveria dar mais atenção a isso. Mas agora me fez dar mais valor a esse sonho, que é um começo para eu tentar pensar no que aconteceu no sonho. Legal e eu gostei de compartilhar".

A mesma participante que o questionara a respeito da importância do sonho perguntou se ele ligara para a pessoa do sonho e ele disse que não, que seria melhor deixar para lá, em tom de brincadeira. Neste aspecto, vale ressaltar a curiosidade e o interesse, mas também o respeito e cuidado do grupo em não invadir o sonho e a intimidade do Pedro.

Encerramos o encontro com a atividade de procurar tirar o "peso", de limpar. Aqui é possível estabelecer uma conexão com as operações alquímicas apresentadas por Edinger (1984). Pode-se perceber temas relativos à solutio, a operação alquímica frequentemente associada ao chorar, tem também a ver com aliviar-se, fazer uma limpeza.

Posteriormente, eu e a colaboradora conversamos sobre esta atividade e percebemos que o fato de poder existir um espaço para sentir o pesado, o incômodo e a angústia também pode ser capaz de conter a experiência como um todo, não sendo necessário estar sempre bem e resolvido, uma vez que o alívio só é atingido quando o peso é sentido em seu limite.

\section{Contribuições do Registro do Encontro}

\section{Este encontro, em três palavras, foi...}

As palavras mencionadas neste terceiro encontro (ANEXO G) margeavam um aprofundamento dos sentimentos, a maioria estava tocada e atingida pela irrupção de sentimento, o que é demonstrado pelas palavras escolhidas: Intenso, impactante, marcante, tensão, visceral, triste, pesado, padecimento, compadecer, forte, emocionante, alívio, aliviante.

Não aparece mais a menção a desconforto, incômodo, conflito, guerra, receio, dúvidas, o que indica que parecem ter sido expressos de alguma forma, no lugar, existe 
intensidade, força e peso. O grupo está ganhando densidade, está se co-formando, e este movimento acontece no testar dos limites, no experimentar o peso e o alívio e também encontrar vazão para os mesmos e ao lidar com a diversidade.

Também mencionam as palavras: identidade, pessoal, revelador, sincero, abraço, sorriso, encontro, indicando mais um aspecto da formação do grupo em que o prazer da troca aparece e é possível se sentir descontraído, animado e divertido.

Interessante pensar as relações entre os sonhos trazidos e o movimento do grupo, que vinha trazendo uma tensão contínua até o terceiro encontro. O primeiro sonho era impetuoso, havia o desejo de atacar para acabar com a situação angustiante, que não se podia mais tolerar. No segundo sonho, apesar de haver intensa luta contra um urso, sabia-se que não se podia vencê-lo sozinho, e a ajuda vinda de fora, que era imprescindível, não se concretizava.

E, finalmente, um sonho em que se chora, em que se sente o alívio por ter deixado vir à tona tantos sentimentos guardados. Foi marcante o movimento trazido pelo sonho do Pedro, em que um conteúdo esquecido e aparentemente enterrado ressurgiu com força e atingiu alívio através da sua expressão. Parecia que o maior sentimento evocado pelo sonho se referia a dar vazão, expressar e colocar a emoção para fora. Em relação ao sonho a expressão foi conquistada através do choro, já em relação ao grupo, através do compartilhamento com os outros participantes. Também foi importante perceber que o sonho chegou ao grupo por uma via emocional, é a emoção, e não o "conteúdo narrado", que pareceu crescer e tomar espaço no grupo. Haveria aqui também uma tristeza por uma separação amorosa? Isto faz pensar no que é deixado para trás quando se faz uma grande passagem, como aliás é o ingresso na faculdade.

Os participantes do grupo pareciam estar mais calmos, soltos, à vontade, dando alguns indícios de estar em intenso processo de constituição, sendo perceptível maior sensibilidade e identificação entre os membros que também comentaram sobre o estreitamento de vínculos durante a semana que se seguiu aos encontros.

\section{Receber o sonho do meu colega...}

Sobre receber o sonho os participantes comentaram que foi uma experiência rica, na qual puderam se identificar com o sonho, com a temática, e com o sentimento do sonhador, experimentando uma sensação de união e comunhão, de não se sentir mais o único, ou envergonhado pelo conteúdo do sonho, e para alguns, houve identificação com a angústia, 
tristeza e peso, o que pode ter permitido que esses sentimentos também pudessem ser trazidos à tona em um espaço em que foram permitidos e reconhecidos. Sendo assim, é pertinente usar a própria fala de um dos participantes: "foi algo que mais nos uniu do que nos separou, mesmo que o sonho, teoricamente, seja o que temos de mais individual e particular".

O clima e o ambiente parecem ter permitido que se vivesse um aspecto relacionado à possibilidade de confissão, por meio de compartilhar o sonho perturbador.

Diz o ditado que confissão faz bem à alma. Jung considerava a psicoterapia como extensão, em feitio moderno, da prática religiosa antepassada da confissão. Revelar segredos obscuros e profundos faziam parte de qualquer tratamento analítico de longa duração (STEIN, 1998, p. 34).

Também demonstraram o aspecto da responsabilidade pela confiança e a necessidade de uma concentração e escuta atenta ao mundo do outro e a possibilidade de vivenciar a diversidade, seja no modo de sonhar, seja no modo de relatar, como construtora de novas perspectivas, alimentando um espírito de curiosidade, de vontade de aprender e conhecer mais sobre os sonhos e sobre as histórias de vida.

\section{Oferecer o sonho para o colega/grupo...}

Dentre as respostas a respeito de oferecer o sonho, vemos que os participantes reviveram os sonhos e as sensações e que puderam significar as imagens do sonho durante a troca, e nesta, perceber que "há mais de um "modo" de ser sujeito de um sonho".

Muitos mencionam a respeito de sentir-se vulnerável, ao expor algo da interioridade e intimidade. Felizmente, avaliaram a exposição de forma confortável e harmoniosa, sentindose acolhidos, leves e aliviados principalmente por não terem sidos julgados ou então por identificação, abrindo-se então uma possibilidade de sentir prazer e diversão no processo de exposição e compartilhamento.

\section{O que levo daqui...}

Os participantes mencionaram levar compreensão mútua, identificação e compadecimento, aspectos que, mais uma vez, inserem-se no âmbito da consolidação do grupo, além de reflexões acerca do sonho de um colega, do próprio sonho ou próprias dificuldades. 
Também relataram levar uma visão diferente daquela com a qual se entrou e mais interesse sobre os sonhos e suas diversidades e possibilidades, além da sensação de que sonhos dizem coisas ou trazem situações que devem vir à tona pois não viriam de outra forma, esboçando uma forma de entendimento para o processo onírico.

\section{O que deixo aqui...}

No terceiro encontro, continuam deixando um pouco de si mesmos e desejam que esta entrega seja também significativa para os colegas e que eles possam também se identificar por sentimentos, opiniões e reflexões, seja ao deixar um pouco da história, da personalidade, da forma de enxergar os próprios símbolos, da possibilidade de ajudar os colegas no entendimento dos sonhos; seja ao deixar parte da timidez, pedaços esquecidos da história de vida, um sonho que significa algo, aspectos íntimos que parecem procurar por reconhecimento.

Também deixam curiosidade, reflexão sobre um sonho curioso e sobre diferentes tipos de sonhos e entusiasmo para o próximo encontro. 


\section{QUARTO ENCONTRO: DESCOBRINDO POSSIBILIDADES}

O grupo pareceu bastante calmo e tranquilo quando iniciamos a nossa rodada a respeito do que permanecera do último encontro e de como fora a semana, sobretudo em termos de sonhos. Alguns disseram não se lembrar muito dos sonhos, ou terem deixado para anotá-los depois e então, os terem esquecido. Outros, por sua vez, haviam sonhado mais e tido sonhos marcantes.

Em geral, disseram ter gostado bastante do último encontro, sendo que mencionaram aspectos muito positivos sobre contar o sonho para outro participante, principalmente pelo fato de sentirem o compartilhamento em dupla como algo mais íntimo e protegido.

"Foi legal compartilhar os sonhos, eu achei inédito, sei lá. Não sei se eu já tinha feito direito isso antes, digo não de ser recíproco, contar eu já cheguei a contar"

"No particular tem mais tempo de debater os detalhes, às vezes uma coisa que você não achava importante alguém chama atenção e você fica pensando".

"Da semana passada eu acho que gostei sim de conversar só com uma pessoa, acho que é uma coisa mais íntima, tanto eu falar quanto a pessoa falar do que abrir assim para um grupo".

"Eu gostei do último encontro, ficou assim uma sensação boa de ouvir".

O Pedro, que expressara o sonho para o grupo no último encontro, trouxe um comentário muito relevante, visto que nos primeiros encontros falara sobre a dificuldade de entender e aceitar seus sonhos:

"Semana passada o encontro foi muito diferente para mim, para mim me marcou bastante, foi importante para mim o encontro. Por jogar no grupo o sonho que eu tive, foi... trouxeram sensações novas, meio que me fez sentir mais coisas do que... acho, que é sempre uma coisa muito boa. Aquele sonho tinha se banalizado, mas era uma coisa muito sensível com o compartilhamento eu até pensei mais e voltou a ser uma coisa mais tocante para mim, que eu acho que é muito positivo. E eu sonhei várias vezes essa semana porque ... porque eu não sei (risos) mas a semana foi muito cheia, eu fiz muitas coisas, eu fiz duas viagens, eu fiz muitas coisas, mas eu também descansei bastante, renovei, reciclei muitas coisas na minha cabeça, deixei muitas coisas se assentarem e acho que então quando eu ia dormir eu tinha mais calma e assim eu conseguia talvez ... quando eu estou mais calmo e mais sereno na hora de dormir, com a cabeça mais satisfeita assim, de estar mais com o pé no chão, com a cabeça na terra ... o sonho é mais lúcido, eu vejo ele melhor. Então acho que sonhei todas as noites essa semana”. 
Este comentário do Pedro nos leva a pensar na articulação entre sonho e vida e num fluxo que alimenta ambos.

Também é interessante notar que o momento de pausa proporcionado por aquele feriado, o primeiro de vários durante o curso, a primeira interrupção ou "tomada de fôlego" no calendário da iniciante vida universitária deles, foi mencionado por outros participantes, no que diz respeito a começar de fato uma nova etapa da vida.

"Essa semana foi meio que uma semana de colocar as ideias no lugar delas, de se resolver algumas coisinhas que parece que como a gente estava em aula, a gente entrou aqui e já integral, então a gente não tem muito tempo para ficar pensando e ai a semana passada foi meio que "vamos pensar" em coisas que eu tinha colocado pra depois".

"Eu gostei bastante do último encontro, de contar pra uma pessoa e depois de ouvir o sonho que ele escolheu pra ouvir, que foi do Pedro. Acho que seguiu bem a dinâmica dos outros, dos anteriores, fez meio que uma trilogia dos sonhos (risos). A minha semana foi bem diversa, muitos altos e baixos. Por um lado, eu descansei fisicamente, mas eu não assentei as ideias igual o Pedro falou, acho que pelo contrário, as ideias estavam bem assentadas esse começo de ano, mas agora essa semana deu uma bagunçada, mas é normal, tô acostumado com elas bagunçadas, o anormal é elas estarem todas assentadinhas (risos). Então parece que agora eu tô começando mesmo depois desse, parece que esse primeiro mês aqui na psico foi, não sei, sei lá, uma terapia estendida, uma coisa assim (risos) e agora parece que está começando mesmo e assim já essa semana surgiu uns conflitos na minha cidade, na minha casa que agora eu vou ter que me organizar pra ajudar a resolver, então os desafios parece que começaram, mas tá bem... e aí em relação aos sonhos, acho que isso interfere nos sonhos, meus sonhos dessa semana foram bem, eu sonhei várias vezes e eu anotei alguns e teve sonhos bem bons e outros nem tanto, mas as pessoas daqui estiveram bastante nos sonhos acho que porque eu não estava vendo vocês no dia-a-dia, aí pra repor assim...(risos e suspiros do grupo, que gosta do que ele diz) porque eu sonhei bem mais do que antes e em poucos dias. No domingo eu já estava assim sonhando com todo mundo, com várias pessoas, não só uma ou duas, mas várias e não sei, acho que porque a gente não estava se vendo, mas foi bem rico assim, em material de sonhos. Foi bom”.

Continuam percebendo os sonhos e lançando novos olhares sobre seu conteúdo, buscando relações e sentidos, além de se evidenciar a movimentação psíquica deste novo período.

"Quando eu acordei eu percebia muito nos sonhos que eu estava passando tanto sentimentos bons quanto sentimentos ruins, parecia que eles estavam aparecendo no sonho do tipo "olha pra mim”, "eu estou aqui ainda”, e sei lá achei estranho porque eu acordei, não conseguia organizar, eu 
sentia que elas estavam, tem que ter alguma coisa que eu não estou dando atenção, foi meio isso, não sei se é porque eu não estava dando tanta atenção assim pra essas coisas todas, mas sei lá, uma coisa que eu percebi tipo sentimentos bons e ruins estavam lá nos sonhos".

"Essa semana eu achei muito engraçado os sonhos que eu tive porque todos eles foram em ambiente escolar, não necessariamente na escola, mas tipo eu tive sonho com as pessoas da escola em sala de aula. Todos eles foram em sala de aula, aqui e no cursinho e na escola e tipo era minha semana de férias então não entendi o que estava acontecendo (risos), achei isso meio engraçado".

"Eu passei uma semana na casa da minha familia e quando voltei para cá, cheguei ontem, sonhei com eles e deu para entender um pouco o sonho, depois que a gente começou a conversar mais sobre eles deu para notar que tem algumas ligações assim com o inconsciente".

"Tive um só que foi marcante, que foi algo relacionado com o que eu já estava conversando com outra pessoa e foi assim um tapa na minha cara do que eu tinha falado [...] e do sonho que eu tinha discutido com a pessoa eu meio que acabei conversando com outra pessoa e meio que dei um significado novo para esse sonho, que já é um sonho antigo que eu trouxe depois e não sei mais se eu quero falar dele agora".

Iniciei a explicação da atividade do dia que consistia na modelagem de um aspecto do sonho de outro participante, que "confidenciaria" seu sonho para ser modelado. Assim que a atividade foi explicada, alguns participantes trouxeram algumas dúvidas quanto à atividade e quanto aos sonhos. Alguns relataram não conseguir lembrar os sonhos, ou então os consideraram bobos e mencionaram que teriam muito trabalho em modelar.

Então, concordamos que a escolha poderia ser feita pelo mesmo sonho já trabalhado em outros encontros ou que poderia ser um sonho mais recente, caso sentissem tal necessidade. Alguns tiveram dúvidas em relação ao conteúdo do sonho ser difícil de ser modelado, eu comentei então que poderia ser uma cena, personagem, ou até mesmo uma impressão ou a sensação que se dera ao ouvir o relato do sonho.

Em relação a deixar o relato de sonho registrado no gravador, foi possível perceber um certo desconforto, natural. Porém, era uma parte importante da pesquisa, e, de fato, os sonhos registrados foram bastante importantes, pois indicaram uma continuidade dos temas que estávamos tomando contato.

Soltaram-se bastante com a argila e as modelagens e a atividade foi permeada por tranquilidade, concentração e leveza. Enquanto esperavam pelo relato de sonho a ser modelado, podiam aproveitar e "brincar" com o material, manuseando-o, explorando-o e 
criando formas fortuitas. Este período de interação com o material se revelou muito importante, uma vez que acabaram por criar formas não diretamente relacionadas com os sonhos e que se revestiram de um novo sentido para o grupo.

Conversamos brevemente sobre o processo de modelagem. Alguns comentam que gostaram muito do processo, que gostariam de repeti-lo outras vezes, sendo que enfatizaram a possibilidade da terceira dimensão e o que ela evoca em termos de dar definições e contornos mais precisos.

"O legal também é que é em $3 D^{8}$, não é que nem um desenho que você não consegue dar tanta dimensão. Aqui você tem que dar todas as dimensões, todos os contornos..."

"Dá pra montar uma postura que no papel não dá, pelo fato de ser em 3D".

"Acho que principalmente pra quem não tem muita habilidade artística, que nem eu, eu me vejo meio obrigada a pensar em um jeito mais inusitado de representar, acho que a Anna tinha falado "ah não dá pra representar o meu sonho", mas você pensa: o que ele representou pra mim? Como eu posso concretizar isso? Não necessariamente um elemento, a porta que estava no sonho, mas o que essa porta representa pra mim...".

Em seguida, perguntei a todos o que fora marcante ao ouvir o relato do sonho e o que haviam querido enfatizar na modelagem, uma sensação, uma cena ou personagens.

"Foi um personagem".

"Acho que ficou uma cena, mas também uma sensação, não sei qual dos dois marcou mais, mas eu acho que a cena porque a sensação não dá pra colocar no concreto”.

"Pra mim foi o contrário, eu não conseguia colocar a cena, mas eu consegui, eu tentei expressar a sensação".

"Acho que foi o movimento que ficou mais... foi uma ideia de movimento, de uma coisa mudando, mais do que uma ação, ou uma cena, foi mais a dinâmica do sonho”.

"Eu acho que o que mais chamou atenção foi uma palavra que você usou, eu acho que ela resumiu muito bem o que você estava tentando passar".

"Eu não sei, o que eu estou fazendo não tem muito a ver com a minha impressão mais forte do sonho do Igor. A impressão que eu tive mais do sonho dele é de uma coisa de ordem bem pessoal pela aparência do sonho, eu não peguei, pode ser até bem aparente, mas eu não peguei. É uma situação de estranheza e essa estranheza era o sentimento mais forte que eu tive".

"Pra mim quando ele foi falando eu fui pensando como que eu podia transformar isso numa coisa modelável e a partir do que ele falou, não foi nem a cena, nem uma sensação, foi mais algo que eu senti que representava o que do sonho dele me chamou mais atenção".

\footnotetext{
8 Tridimensional.
} 
"Ela falou que ia ser difícil, mas eu não achei tão dificil assim. Eu representei mais uma cena, mas também a sensação associada a essa cena porque a cena, de fato, é algo difícil. Mas acho que saiu, apesar de tudo".

"Pra mim o que mais ficou foi uma sensação de divertimento, foi o maior ícone que eu consegui encontrar do que ele me contou".

"Pra mim foi uma cena e um objeto. Não necessariamente ligados".

"Pra mim foi uma cena mesmo e o que essa cena podia representar metaforicamente, pelo menos o que eu acho".

"Pra mim foi um personagem e uma sensação de alegria".

Então, no final, criaram os títulos para as modelagens e responderam ao Registro do encontro (ANEXO H). As fotografias das modelagens, com a transcrição dos sonhos respectivos sonhos estão no ANEXO I.

Os participantes mostravam-se bem alegres e prestativos, foi possível perceber que a experiência havia sido criativa e gostosa, conversavam animadamente. No final, ajudaram a recolher o material, as bacias, pedaços de argila, sacos plásticos, papel, deixando a sala limpa novamente.

\section{Contribuições do Registro do Encontro}

\section{Este encontro, em três palavras, foi...}

Foi bastante interessante notar que neste encontro, as palavras representam um outro momento, em que se nota uma tranquilidade maior do grupo, com vínculos seguros. Então, as palavras: divertido, solto, leveza, leve, ex(pressão), engraçado, bagunçado, dinâmica, diferente, sensorial, ouvir, pensar e criar, desenvolvedor, criatividade, inspirador, inovador e interessante parecem nos mostram que o grupo agora tem energia para se inspirar e criar, rir, bagunçar, privilegiando o aspecto emocional e sensorial do processo.

As palavras: emocionante, nostálgico, profundo, desafiador, reflexivo, pessoal remetem para esse momento, assim como elementos, terra, totem, concreto, que parecem evidenciar simbolicamente o que está se passando no grupo.

\section{Ouvir o sonho do meu colega...}

A maioria relatou aspectos muito favoráveis a respeito de ouvir o sonho, sendo avaliado como rico, instigante, divertido, interessante, curioso, inspirador, sendo um convite 
à criatividade e por poder prestar atenção em algo novo, inusitado e até mesmo bobo e ver a transformação para algo marcante.

Continuam vendo identidade no sonho do colega, e esse "ver-se no outro" é considerado muito positivo, porém também houve momentos em que ouvir o sonho foi angustiante ou foi sendo possível perceber relações novas para os sonhos dos participantes.

\section{Modelar um aspecto do sonho do meu colega}

Em relação à atividade de modelar, a mesma foi considerada divertida, engraçada, diferente, inusitada e gostosa em seu processo, por envolver a criação manual e uma nova perspectiva, mas também séria, frustrante, desafiadora e difícil, uma vez que a representação tridimensional ficou a desejar para alguns dos participantes.

Por outro lado, trouxeram que o aspecto inusitado facilitou a exploração do recurso, mostrando diferentes formas de expressão, possibilidade de concretização e até mesmo liberdade para criar, uma vez que a falta de habilidade técnica permitiu um processo criativo mais solto, visto que a maleabilidade da argila permite novas configurações para o sonho e o seu entender.

\section{Ver um aspecto do meu sonho modelado...}

Levando em conta que modelar um aspecto do sonho do colega foi divertido, mas também desafiador, ver o sonho modelado pelo colega foi entendido como interessante, engraçado e diferente, pois permitiu certa organização das imagens do sonho, e também novos modos de ver o sonho, auxiliando, inclusive, um dos participantes a libertar o sonho de um aspecto angustiante e paralisador, pois quando o viu "materializado", sentiu o sonho despessoalizado e mais universal, o que trouxe auxílio para lidar com os medos evocados pelo mesmo.

Em alguns casos, houve dificuldades na comunicação do sonho, que influenciou na forma como as modelagens foram recebidas. Um dos participantes revelou que o sonho se tratava de conteúdo muito íntimo, o qual não se quis expor, e outro relatou não ter entendido as intenções do modelador. 


\section{O que levo daqui...}

Do terceiro encontro, os participantes relataram levar sorrisos, elogio, diversão, aprendizado, pensamentos, um sonho para refletir, uma experiência diferente que possibilitou novas formas de expressão e de olhar para os sonhos, desta vez, com outras perspectivas.

Também mencionam a respeito de uma sensação progressiva de consolidação do grupo, a qual parece, neste momento, levar para um nível em que possam experimentar seus sonhos e dos demais colegas, em um ambiente de associações e compartilhamentos seguro.

\section{O que deixo aqui...}

Ao final do penúltimo encontro, deixam curiosidade, diversão e revelam se esforçar para expressar sentimentos e sensações do colega, contribuindo para uma nova apreensão, seja através da busca de entendimento e reflexão, seja através do envolvimento sincero com as atividades.

Um dos participantes diz que deixa bastante coisa, o que o faz sentir positivamente descarregado, outro quer deixar a incapacidade de encarar algo e uma visão superficial sobre o sonho.

Em relação aos sonhos compartilhados, aparecem o ambiente escolar, seja a escola, cursinho ou a própria faculdade em quatro sonhos.

Dois sonhos trazem a temática da morte, em um deles é a morte da mãe que ocorre, trazendo medo de encará-la e constatá-la de fato. No outro é a própria morte que se experimenta e nesse processo se conhece diferentes ambientes e etapas.

Os sonhos também trouxeram a possibilidade de fazer parte de uma torre de pessoas na praia, para, em seguida, ao sair dela, vê-la cair e desmanchar. O sonhador sentiu-se aliviado por ter saído dela na hora certa. Há também experiências de estranhamento, como comemorar o aniversário no lugar do irmão, de não conseguir prender o cabelo para participar de uma luta importante, de estar incumbida de procurar algo e no caminho se deparar com uma menina escalando um lugar improvável. Também se vivenciou o impedimento de falar e fazer contato com uma personagem do sonho, a qual estava em outro momento da vida e com outros interesses.

Um dos sonhos traz angústia e conflito por ter havido uma briga com o irmão mais velho, seguida de uma perseguição por lobos, sem a ajuda da mãe, que está por perto. Há aqui 
uma semelhança com o sonho trabalho no segundo encontro, em que a sonhadora pede ajuda à mãe e ao namorado, mas eles não ajudam e ela precisa, sozinha lutar contra o urso, indicando uma mudança de postura da mãe, que não dá mais conta de resolver pelos filhos, significativa de uma necessidade de independência dos filhos, que precisam aprender a lutar e a se defender sozinhos. Também há o sonho de estar sozinha na escola e presenciar uma tempestade iminente.

Houve um sonho que sintetizou a experiência de união através de diversos desenhos animados e da constatação de que personagens se foram e que outros permaneceram, deixando um clima de paz.

Em relação às modelagens (ANEXO I), é possível ver que a maioria esboça um movimento, algo está acontecendo e/ou em relação, seja entre os personagens, seja contida na imagem principal. Os títulos indicam aspectos positivos de movimentos e assimilação do que se é novo e apareceram então possibilidades, escolhas, tentativa, ascensão, escalada, up $n^{\prime}$ down. O movimento era direcionado para o alto e para baixo, havia escada e elevador, havia também uma escalada improvável e uma torre de pessoas que executava um movimento pendular até cair. Também se percebeu movimento circular ou configuração circular na modelagem, remetendo ao simbolismo de Héstia e do próprio self, assim como à operação sublimatio, relacionada à ascenção.

Foram feitas nove modelagens com representação humana, mostrando que parecia haver neste momento uma identificação maior e a construção de uma postura individual, diferente da representação através do desenho, no segundo encontro, mais pautada em cenas a partir da perspectiva de um observador externo.

As demais constituem-se de um objeto, o pião; uma representação de movimento, tanto em espiral, quanto para o alto e para baixo; e um sinal de que não se pode falar. À parte, foram modelados três patos, considerados os psicopatos, que são os mascotes do curso. Podese imaginar que tais personagens aludem a algum desconforto ao se perceberem sendo expostos e pesquisados, e também sendo calouros, sintetizando este momento inicial.

Alguns títulos indicavam desfecho, desespero, angústia, conflito, impedimento e indiferença, aspectos presentes no decorrer dos encontros. Outros mostravam elementos da natureza, havia fogueira, chama, brisa, solidão tempestuosa, podendo indicar energia vital, e levando-nos a acreditar que não se mantiveram apenas passivos durante os encontros. 


\section{QUINTO ENCONTRO: ALÇANDO NOVOS VOOS.}

No último encontro percebemos um movimento diferente; eles estavam um pouco mais quietos, retraídos, pensativos, e alguns chegaram um pouco atrasados. Então, começamos com uma sugestão da colaboradora, de usar bolinhas de tênis para massagear os pés.

Comentaram que gostaram muito da sensação, que os pés estavam nas nuvens ou que um pé parecia mais pesado que o outro. Ainda em pé, conversamos sobre a semana e disseram que teriam a primeira prova do semestre, mostrando-se um pouco preocupados. Ficaram mais tempo em silêncio que o habitual, haviam pausas maiores entre um comentário e outro.

Uma participante disse que pela primeira vez sonhara com algo relacionado à Psicologia, mas ficara triste por isto ter antecedido o último encontro e não poder ter tempo para trabalhar com o sonho no grupo.

"Ah! Pela primeira vez desde que a gente começou eu tive um sonho relacionado à psicologia, porque eu acho que como a gente vai ter prova amanhã, na minha cabeça veio ah a primeira prova, não sei fazer prova".

Explicitamente sobre o fim do grupo, outros participantes também trouxeram comentários, sendo que um deles sugeriu para que que continuassem se encontrando e compartilhando os sonhos.

"Tô meio triste de estar acabando, eu gosto dos encontros, da parte de dividir os sonhos, eu acho bem legal".

"Acho que foi muito legal essa oportunidade do grupo, passou muito rápido, acho que esse mês passou muito rápido e vai ficar uma boa lembrança".

"Também estou meio triste que vai acabar, achei bem legal. Eu até sugeri pra eles que a gente continuasse se reunindo, não necessariamente pra falar das mesmas coisas, mas assim pra compartilhar os sonhos, coisas nesse sentido”.

Comentamos sobre os sonhos durante a semana e a maioria relata ter tido sonhos diferentes ou em quantidade maior. Um deles falou sobre sonho lúcido e outros se mostraram confusos quanto ao conteúdo, não sabendo discriminar se haviam sonhado ou vivido a situação, ou não conseguindo lembrar o conteúdo do sonho. 
"Tive um sonho meio que real, quando eu estava sonhando, eu não sabia se era realidade ou não na hora, se eu estava dormindo ou acordado".

"Eu lembro de umas coisas, mas não sei dizer era um sonho ou não era, eu lembro de, não de imagens, nem nada, lembro de sensações, mas não sei se eu tive elas ou se foi um sonho, eu não consigo lembrar".

"Eram sonhos muito legais e eu ficava muito empolgada e eu tive um sonho, um modelo do sonho que eu nunca tinha, ou pelo menos que fazia muito tempo que eu não tinha tido, que era aqueles que você sonha, eu não sei se é aquele negócio, não foi pânico noturno com certeza, eu sonhei que eu estava no meu quarto. Só que eu via uma coisa que podia ser, mas não podia. Acho que eu posso comentar rápido. Eu vi um gato meu, só que a lembrança é que eu vi um gato meu que morreu há pouco tempo, foi uma coisa que abalou bastante".

Nesse momento de contar sobre os sonhos e a semana transcorrida começaram a ficar mais animados, então, iniciamos uma conversa sobre o processo de modelagem ocorrido no encontro anterior, ouvindo as intenções do modelador e observações do sonhador. As imagens das modelagens estão no ANEXO I.

Heitor, que foi o primeiro a compartilhar seu sonho e a sua impressão, comentou:

"Comparando com o desenho, escrita e até mesmo com contar, a modelagem é a que você mais pode mudar o percurso, você está fazendo uma coisa e aí vai surgindo outra ideia, vai surgindo outro tom, outro clima do que você está pensando e você vai mudando porque a argila ainda está molhada, ainda está maleável, então você consegue fazer isso. E nem mesmo na narrativa você tem tanta liberdade, você pode comprometer sua coerência. Na argila não, então acho que foi bem legal ela ser o último, a técnica que a gente viu depois das outras, acho que complementou bem com o contar primeiro o sonho e depois você fazer isso e um fazer do outro também é bem legal porque você vê como que o seu sonho, ele passa por outra pessoa para chegar na... antes de se solidificar ele passa por outra consciência. Então, achei um processo legal, interessante e, foi assim, contar foi legal e modelar também porque você fica com uma preocupação de tentar ser fiel a ideia do sonho de outra pessoa, porque não é o seu sonho, apesar de ser a sua obra. Então é meio que, você tem que saber unir essas duas ideias de uma coisa que é sua e uma coisa que é do outro. Bem legal, cada uma delas representa uma união de duas coisas".

No sonho do Heitor, a sua mãe morria, mas ele não tinha certeza da morte. Havia uma canoa com o possível corpo rodando por um rio, mas ele não conseguia ver quem era, ele corria para ver, mas não conseguia, o que trazia angústia e medo. Disse ter gostado da representação da Catarina, porque o que está embaixo do corpo (Figura 19) tanto pode 
representar a correnteza da água quanto a chama do fogo. Também comentou que a visualização o ajudou no título: A chama apagada.

Perguntei se ter visto o sonho modelado favoreceu outra perspectiva sobre o sonho. Aqui está sua resposta:

"Agua e fogo juntos são uma coisa muito intempestiva, uma coisa que é muito instável e eu acho que a argila que se seca depois traz um pouco de estabilidade para as ideias. A ideia que o sonho traz é clara, é o medo, uma angústia, que envolve várias angústias, mas aí eu acho que ajudou a solidificar, a colocar cada coisa em seu lugar”.

Catarina diz que resolveu representar a cena que o sonhador não viu e que apenas supôs que ocorreu, e queria dar forma à incerteza que o sonho gerou, mas não havia tido a intenção de representar o contexto da água e fogo. Comentou que quando estava modelando se preocupou em deixar a argila lisa, o que influiu na postura da pessoa, chamando atenção para uma suposta passividade, visto que está sendo queimada, mas permanece tranquila, com os braços abaixados. Disse que o título escolhido para a modelagem é Angústia, pois foi isso o que sentiu quando Heitor contava o sonho.

Heitor completou dizendo que achou que ficou mais legal assim, que permitiu outras visões e que ele gosta da ambiguidade, porque é um sonho rico.

Em seguida, vimos o sonho modelado de Catarina (Figura 17). Ela comentou que se arrependeu de ter escolhido o sonho, e, por sentir vergonha do significado dele acabou não explicando muito, dificultando as possibilidades de representação pelo modelador, o qual relatou ter percebido que a modelagem feita não correspondia aos seus sentimentos, porém não conseguiu fazer de outro modo.

Catarina disse que o próprio título dado foi Brincadeira de criança, porém revela mais uma atitude infantil do que de fato uma brincadeira. Também relatou que não foi a primeira vez que sentiu esse desconforto e no encontro anterior também não quis explicar o que achava que tinha por trás do sonho.

Pedro teve o sonho modelado pela Anna, (Figura 22), a qual havia feito modelagens de patos previamente à modelagem do sonho. $\mathrm{O}$ pato maior foi identificado como Psicopato, ou seja, a mascote do curso de Psicologia. 
Sobre a modelagem, Pedro disse que foi bem o ponto do sonho, da questão do sonho, bem certinho. Sentiu que no sonho estava alheio, e ao contá-lo não reconheceu as emoções vividas, porém acredita que ela tenha percebido a questão do sonho.

Os títulos dados foram: Não fale. Não se pode falar e Impedimento. Houve comentários a respeito do impedimento por uma imposição externa ou interna, ao que Pedro complementou dizendo ser dele mesmo. A Anna comentou que do sonho relatado, o que ficou mais importante era o não conseguir falar, e que isto a guiou na representação.

O sonho da Anna foi modelado pelo Leonardo (Figura 26) e o grupo observou bastante animado, buscando atribuir vários sentidos. Comentaram da semelhança com um suricate e deram risadas. A Anna contou para ele uma imagem que lembrava do sonho, a qual ele representou muito bem. O Leonardo, por sua vez, disse ter gostado de modelar o sonho da Anna, e assim que ela contava já foi pensando em representar uma pessoa, a solidão e o desespero. Os títulos dados foram Sozinha e Solidão tempestuosa.

O Leonardo também comentou que com a argila dá para ter mais possibilidades e ele conseguiu fazer um cenário de tempestade e ela está um pouco inclinada e com os cabelos ao vento.

O sonho do Leonardo foi a Ana Maria quem modelou (Figura 21). Para o Leonardo foi interessante o fato de ela ter representado de outra maneira, diferente da imagem do sonho, mas preservando a ideia central. Também comentou que no final da atividade, a torre caiu e era exatamente isto o que acontecia no sonho.

A Ana Maria buscou retratar no sonho o divertimento que ele demonstrou ao contar o sonho, e ela ficou com a imagem de uma pirâmide de pessoas, ao invés de uma em cima da outra. Ao lado tem um bonequinho que se encontra no topo, representando o prédio no qual o sonhador ficava. Os títulos foram Brisa e Escalada na praia.

A Valkyria modelou o sonho da Ana Maria (Figura 23), a qual achou que ficou muito bem representado, sendo uma síntese de diferentes partes do sonho que foram as principais: $a$ menina segurando a espadinha e o cabelo caído.

Valkyria achou que o sonho era divertido e como não saberia representar um sentimento ou materializá-lo, optou por retratar o que achou mais marcante. Assim como a Anna, Valkyria modelou duas figuras aleatórias antes, que não fazem parte do sonho. 
Os títulos foram Cabelo e espada e Alt: Sandá Descabelado. Valkyria disse que queria fazer um trocadilho no título, pois a faca era do Sandá ${ }^{9}$ e o cabelo estava descabelado, pretendia um título que mostrasse junção, como sandáescabelado, mas optou por Sandá descabelado.

Quem modelou o sonho da Valkyria foi Amélia (Figura 24), que, segundo Valkyria, deu um ar mais alegre do que o sonho em si tinha e um clima familiar e aconchegante, devido aos bancos e troncos ao redor de uma fogueira.

Os demais participantes também ficaram entusiasmados com essa modelagem, gostaram dos títulos, a saber, Fogueira Ideal e Acampamento com Platão, comentaram do aspecto estético e da postura do bonequinho, que é Platão ${ }^{10}$. Um deles comenta que "a cena é legal, dá vontade de ficar aí, virar um bonequinho e sentar no banquinho".

Amélia disse que gostou muito de ouvir o sonho da Valkyria, que é o melhor de todos em sua opinião, pois foi complexo e continha várias partes que se encaixavam. A cena que optou por modelar foi a que no sonho resumia tudo. Há uma situação de conflito, de luta com armas e ela morre:

“aí ela vai pra um, não é o céu, mas pra uma vida após e, aí ela se reúne ao redor da fogueira com outras pessoas, uma das pessoas é Platão. E aí o que eu tinha entendido é que quando ela chegou nessa fogueira com outras pessoas e Platão, foi meio como se ela tivesse encontrado uma conclusão pra história dela, tivesse finalmente entendido tudo o que ela passou e aí ela chegou num ponto que, tudo bem, eu aceitei, não tô mais preocupada que eu estou morta. É por isso que ela está nessa posição mais relaxada e a ideia dos outros troncos é pra mostrar que mesmo que ela esteja sozinha, ela não está sozinha, está acompanhada por outras pessoas”

Valkyria também contou que, no sonho, todos em volta da fogueira contavam como havia sido sua respectiva morte e como estavam chegando. Outros participantes demonstraram atenção e gostaram do sonho e da maneira pela qual foi feita a representação.

O sonho da Amélia havia sido modelado por Patrícia, que não estava presente no encontro (Figura 25). Ao contrário dos colegas, Amélia disse que contou apenas a explicação e a sua interpretação do sonho, não o sonho em si, porque queria que ela tivesse uma impressão específica. Assim, a Patrícia tentou representar muito os sentimentos e conclusões metafóricas passadas por Amélia.

\footnotetext{
${ }^{9}$ Luta marcial japonesa.

${ }^{10}$ Platão foi um importante filósofo grego e matemático da Grécia Antiga.
} 
Amélia comentou que a Patrícia tinha explicado um pouco suas intenções: quis modelar um centro e um bonequinho que representasse em si a união de todos os personagens, porém no sonho de Amélia havia uma união de diversos desenhos animados, Pokémon, Hamtaro $^{11}$ e Naruto, que estavam em relação. Ao redor do bonequinho ela modelou algumas manchas para representar energia, "porque eu falei que sentia uma energia alegre, positiva, então ela colocou essa energia espalhada como se tivesse representando isso”. Os títulos são: Desfecho animado e Eu escolho você!

Sofia foi quem modelou o sonho da Patrícia (Figura 15), o qual trazia numa situação de conflito em que havia pessoas da família dela que não respondiam quando ela os chamava. Assim, os títulos foram: Conflito e Indiferença. Para Sofia, o que mais marcou no sonho foi o fato de haver lobos que pareciam pessoas e tentavam atacá-la. A sonhadora foi representada e disposta no centro da cena e os lobos/pessoas em volta dela.

Quem modelou o sonho da Sofia foi a Beth, (Figura 20) que também havia faltado no encontro. Sofia relatou que o aspecto modelado não fora o aspecto mais importante para ela no sonho, no qual faria novamente o vestibular. "A problemática do sonho era que eu ia fazer a prova só que eu chegava no lugar e não sabia onde era o local da prova. O lugar da prova, no sonho, era parecido com a faculdade, e ela procurava a sala, encontrava professores antigos e pedia ajuda, mas não encontrava. Quando finalmente achou a sala, caiu água na prova inteira, porém, o conflito maior era tentar achar o lugar, perguntar para pessoas que não ajudavam e ir para um lado e para o outro procurando. O que a incomodava era "a situação de eu estar perdida completamente”. Os títulos criados foram: Desespero líquido e Desespero.

Laura foi quem modelou o sonho da Beth (Figura 16). Laura procurou se concentrar no sentimento do sonho da Beth para transmiti-lo em linhas gerais, pois avaliou que não conseguiria representar cenas e personagens. A cena do sonho que mais a impressionou foi quando Beth encontrou um professor de cursinho que, ao invés de acompanhá-la até o elevador, optou por ir de escada com ela, o que segundo Laura não seria o normal a fazer. Ela tentou representar na modelagem uma bolinha que está subindo, com as setinhas que servem de referencial. Os títulos foram: Up'n'down e Escolhas e observações. Outro aspecto do sonho que chamou sua atenção foi o fato haver pessoas da faculdade, do cursinho, do colégio:

"era uma mistura de várias esferas sociais que eu acho que foram significativas na vida dela e eu tentei representar como essa coisa que está, é tipo um DNA, se enrolando, se misturando, mas é uma

${ }^{11}$ Pokémon, Naruto e Hamtaro são desenhos animados japoneses. 
coisa que está alheia a cena porque era como se, a impressão que passava era como se tivesse gente observando o que estava acontecendo, mas não estava dentro da cena que ela estava vivendo".

E assim, fechando o círculo, quem modelou o sonho de Laura foi o Heitor (Figura 18). Laura fez uma observação bastante interessante a respeito da atividade que estávamos fazendo, uma interpretação da interpretação de um sonho, o que a fez lembrar de um poema: "não sei porque essa mania de interpretar poema, porque o poema já não é uma interpretação?". Para ela, "o sonho parece uma interpretação que a gente tem do que a gente vive".

Em relação a seu sonho, Laura enfatizou para o Heitor a questão de dar voltas, mas não conseguia imaginar o hall do seu prédio redondo, o que causou estranheza num primeiro momento. Porém, considerou que a ideia é realmente essa: de andar muito e ter a impressão que nunca termina, o que se exemplifica melhor através do círculo. Também comentou que achou muito bacana vê-lo interpretado desse jeito, pois como foi um sonho que a assustou, vê-lo dessa forma: “não parece, não era tão horrível assim olhando com calma”. Os títulos dados para essa modelagem foram: Possibilidades e Ciclo no chão, marcha em ascensão.

Catarina comenta que o sonho da Patrícia lhe apresentou alguns pontos em comum, a imagem de lobos e pessoas misturados faz parte de um quadro que lhe é significativo, além de já ter tido uma época em que sonhava com lobos. Gostaria de poder saber o sentido dos lobos para a Patrícia.

Durante o momento em que modeladores e sonhadores expunham seus pontos de vista, eu e a colaboradora permanecemos bastante observadoras, investindo em comentários para que continuassem a elaborar suas próprias ideias. A colaboradora teceu comentários interessantes, principalmente no que se refere à complementação e ampliação de diferentes imagens e percepções, visto que aí está a possibilidade de troca e desenvolvimento. Também comentei sobre a questão da interpretação da interpretação, visto que trabalhamos com versões é importante procurar entender o que se deseja representar e enfatizar em um dos muitos aspectos possíveis.

Após esse momento, passamos para a atividade específica do encontro: a composição de uma cena coletiva com as modelagens realizadas por eles. Um a um, solicitei que escolhessem uma das peças e a dispusesse em cima de um colchonete, que se localizava no centro da roda. Além disso, durante a escolha e montagem, pedi para que falassem em uma palavra que representasse a experiência do grupo para cada um deles. 
As palavras foram: pesado, surpresa, perspectivas, subjacente, conhecimento, frente, diversão, comunhão, simbologia, dureza, ver no escuro.

Em seguida, perguntei se alguém queria alterar a disposição das peças na cena, e, neste ato, também dizer mais uma palavra. Então, vieram as palavras: solitude, fantasia, possibilidades, juntos, redenção, confiança, fantasmas, ser.

Abaixo está a fotografia da cena composta:

Figura 2: Composição da cena coletiva.

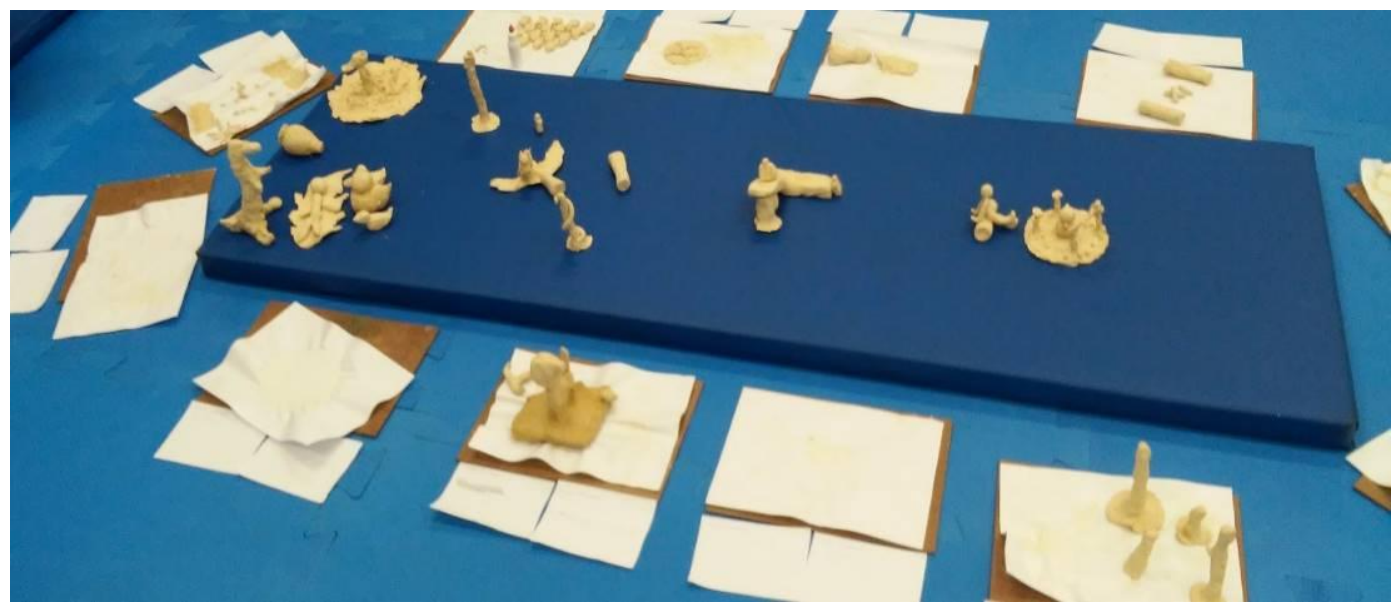

Terminada a composição, passamos para um momento de leitura da mesma, em que cada um expressou suas impressões e interpretações. Perguntei como era olhar para a imagem e para a forma como estavam organizadas.

Um dos participantes comentou que visualizou quatro cenários isolados que poderiam ter uma conectividade, ao passo que outro participante se impressionou ao perceber que algumas das cenas acabaram se juntando, como se houvessem sido moldadas e surgiram comentários a respeito de várias pessoas estarem envolvidas neste processo: houve aquela que modelou, aquela que contou o sonho e aquela que escolheu ou alterou a posição na cena, culminando para uma integração da experiência em grupo, visto que haviam diversas escolhas possíveis.

A partir desse momento, começamos a esboçar as impressões e observações sobre as cenas. Um dos participantes diz que parece haver um espetáculo acontecendo, na direção do qual a maioria das peças está olhando. Outro participante, observa que os sonhos que trouxeram sentimentos mais pesados estão concentrados no lado esquerdo, e contém o lobo, o peão, a mãe queimando e a solidão, lado a que os patos estão assistindo, visualizando uma polaridade. 
Uma das participantes fez uma analogia da cena com o monstro e patos e a participação no grupo vivencial, que foi bem recebida pelos demais participantes:

"Eu achei genial porque eu enxerguei três cenários, um pouco separados também, mas todos eles fazem muito sentido para o que a gente viveu aqui. O pato foi porque aquele lobo/ser humano, para mim aquilo lá era um monstro e quando aquilo foi colocado ali, desse lado tinha majoritariamente coisas boas, então o pato representando a Psico ${ }^{12}$ como uma maneira de enfrentar essa coisa mais...sabe (percebe-se uma comoção do grupo), tipo esse grupo de sonhos enfrentando um monstro".

"É, quando você colocou isso, não que eu enxerguei o lobo como um monstro, mas eu entendi o pato como a paz da psicologia encarando essa coisa".

"Esse seria como um espectador calmo, olhando para uma coisa muito complexa, muito complicada e essa seria como quando a gente conta nossos sonhos aqui, é, assim, a gente consegue, sei lá, se distanciar um pouco e enxergar de uma outra maneira".

"A parte do pato enfrentando o monstro, eu achei legal que depois colocaram os dois patinhos do lado dele, tipo, a gente não tem que, é ruim enfrentar as coisas sozinho, é bom quando a gente tem patinhos do lado também”.

Viram o distanciamento como tranquilidade e possibilidade de enxergar uma nova perspectiva. Então, prosseguimos para a cena em que há um escorregador e uma bolinha nele, sendo que um bonequinho foi colocado na extremidade do mesmo. Conversaram a respeito da direção da bolinha, se está subindo ou descendo, e que pode acertar o boneco, empurrando-o para baixo, ajudando-o a ser atingido, o que é considerado bom e comparado a algo novo.

Então, foi analisado o cenário do meio, o qual o participante que ajudou a montar, que está entre o escorregador e os patos, diz que não está entendendo direito.

"É um cenário diferente, mas pra mim faz sentido eles estarem todos no mesmo universo. É que, sabe o início de Game of Thrones, que ele vai, a câmera e vai indo e vão surgindo todos os reinos. Começa com uma câmera aérea e vai mostrando todos os reinos e vai viajando pelos reinos e tem várias cenas, mas são partes de uma mesma realidade".

"Vocês falaram muito do observador que tá ali olhando a cena, só que se pensar a gente tá como observador olhando todo esse universo porque que nem bem no finalzinho da abertura, uma coisa que sempre me chama a atenção, é que parece que alguém, não sei como que funciona binóculo antigo, monóculo, mas parece que alguém troca uma lente pra ver mais de longe. E parece que a

\footnotetext{
${ }^{12}$ Psico é o apelido carinhoso para a faculdade em questão.
} 
gente viu tudo muito detalhado e agora é como se estivesse trocando a lente, pegando um outro olhar. Acho que é um outro olhar como conjunto".

Então, questionam o boneco que está em cima do pássaro, que chamam de "bichinho", o que chamou minha atenção para o fato de os calouros também serem chamados de "bixos". A participante que montou a cena disse:

"Sempre que eu vejo um pássaro, eu tenho uma vontade, de ter esse momento de ver as coisas de uma vista aérea, de você não estar em contato com o chão, de "estou voando".

Logo em seguida, um participante comentou que parecia que eles haviam matado o pássaro e estavam em cima dele, ou dominando o pássaro.

Finalmente, uma participante completou a respeito do "bichinho" e da forma como a outra participante o dispôs:

"Tinha aparecido um Pokémon, mas aí quando a participante fez ele com a mãozinha assime colocou ele em cima do pássaro parecia que ele estava em movimento, se afastando e dando adeus para alguma coisa, aí eu achei, como ele parece que tá um pouquinho olhando meio pra cima e eu achei, como é o nosso último encontro assim não deixa de ser, a gente tá... não montado numa pomba (risos), mas dá pra continuar nessa vibe, não é uma despedida triste, mas é um tchauzinho feliz. Ele está lá, tipo, tchau”.

Aproveitei o aceno para finalizar, reiterando o aspecto confidencial da pesquisa e mantendo-me disponível para quaisquer informações ou dúvidas. Também agradeci aos participantes e a observadora pela presença e participação ativa e engajada nas atividades e pelo cuidado demonstrado e acolhido para com cada participante do grupo. Já havíamos passado 15 minutos do horário programado e, então, decidimos que o questionário final seria entregue, mas respondido e enviado para o e-mail do grupo. Pedi para que escolhessem o nome fictício a ser mencionado na descrição. E assim, acenando e vislumbrando novos horizontes, nos despedimos.

É importante dizer que três dos participantes não enviaram o questionário respondido de volta. Apesar de tê-los encontrado pela faculdade em ocasiões posteriores e informado da importância dos mesmos na pesquisa, preferi considerar a não-resposta como uma resposta, como um indicativo de que ou ainda não conseguiam formular em palavras, num texto, o que vivenciaram no grupo; ou não queriam colaborar com a finalização dos encontros, uma talvez rebeldia ou transgressão. 
Neste último encontro, foi possível notar um movimento diferente. Mostravam-se um pouco distantes, faziam comentários com pausas maiores, mas não deixaram de participar. Também estavam mais críticos com as suas modelagens e com o fato de não conseguirem passar o sentimento do sonho ou abrirem-se o suficiente para o outro. As divergências pareciam mostrar o lado difícil do crescimento, da discriminação eu-outro, e, em consequência, sentir-se só e diferente. Havia um cenário com partes separadas, mas que mantinha ligação.

O reconhecimento dos limites individuais e grupais sempre foi uma questão trabalhada, mas neste último apareceu de forma negativa, como se fosse possível ter mais entrega e abertura, mas havia algo impedindo, algo que não se podia falar.

A construção da cena coletiva revelou-se como uma experiência de apreciação e consideração do momento pelo qual passavam e acredito ter sido muito importante o reconhecimento de uma força - coletiva - capaz de fazer frente à ameaça dos fantasmas e monstros que tomaram forma.

Estavam despedindo-se. Imagino que não apenas da pesquisa, mas de uma série de elementos, pessoas e situações, que foram trazidos, pelos sonhos, ao grupo.

Porém, também estavam chegando, estavam preparando-se para a primeira prova da faculdade, para alçar um voo que permitisse uma visão ampliada, mas também geral, para serem atingidos por algo novo. 


\section{CONTRIBUIÇÕES DO QUESTIONÁRIO FINAL}

O questionário final teve a função de, por um lado, oferecer um meio para que os participantes pudessem promover uma reflexão a respeito da vivência com o grupo, permitindo organizá-la e significá-la. Por outro lado, visou possibilitar acesso à compreensão acerca do impacto e relevância da participação no grupo, ao avaliar: o modo como os participantes passaram a se relacionar com seus sonhos; o contato com o uso de recursos expressivos e a qualidade da relação que se obteve entre os participantes durante o desenrolar do grupo em termos de exposição, acolhimento e identificação. As respostas estão no ANEXO K.

\section{Como foi participar do grupo vivencial de sonhos?}

A experiência no grupo vivencial de sonhos foi citada como agradável, divertida, séria, positiva, diferente, interessante, enriquecedora, gostosa, legal e informativa.

Comentaram que o compartilhamento e a discussão dos sonhos foram os principais pontos positivos que o grupo trouxe, além de promover o contato com outras formas de expressão.

Além disso, alguns mencionaram que a participação no grupo fez emergir questões pessoais, e que reconheceram nele uma chance de sair da zona de conforto, ao poder processar aspectos da vida, conhecer pessoas e até mesmo relaxar.

Também foi interessante observar que mencionaram a consolidação do grupo vivencial como um diferencial na experiência, no qual se viabilizou o pensar em conjunto e a possibilidade de ajuda mútua em relação à criação de novos e próprios caminhos.

Qual foi o impacto de estar em um grupo falando sobre seus sonhos e ouvindo os sonhos dos demais? Como você se sentiu?

Relataram o aparecimento de sentimentos variados, como alegria, compaixão, tensão, exposição, peso. A possibilidade de poder ouvir os sonhos se mostrou interessante e gostosa, principalmente ao perceber a demonstração de confiança por parte de quem os relatava. 
Quando era a vez de contar os sonhos, avaliaram a experiência como positiva, obtendo uma sensação libertadora e de exposição, que foi considerada favorável.

Alguns comentaram que, em certos momentos, foi desconfortável compartilhar o próprio sonho, por haver incômodo e retraimento. Já em relação a ouvir o sonho dos demais, revelaram que, algumas vezes, houve uma sensação de peso, principalmente com aqueles que eram difíceis de se lidar, porém, esta não foi avaliada como necessariamente ruim. Já em outras ocasiões, houve muita motivação tanto para contar quanto para ouvir os sonhos, reconhecendo uma sensação boa no compartilhar.

Sobre as tentativas de interpretação com a ajuda dos outros participantes, consideraram que a chance de poder ouvir outros pontos de vista, e, com eles ponderar acerca dos próprios, foi uma forma de trabalhar com a diferença e dela extrair contribuições.

Também disseram que foi possível criar relações com questões pessoais e, também, pensar e refletir sobre o que os sonhos dizem sobre os próprios sonhadores, ao apresentar facetas que não reconhecemos em nós mesmos e nos outros, constatação que, para um dos participantes, se revelou impactante.

Mencionaram que sentiram uma conexão diferente com as pessoas com as quais compartilharam os sonhos, ou por sentirem-se acolhidos ou por sentirem que não estavam sendo julgados. Acreditam que a experiência possa ter fortalecido alguns vínculos e que ajudou a respeitar mais os sentimentos dos outros.

Finalmente, comentaram que o embate dos sonhos e a sua ligação com a realidade estimulou maior curiosidade sobre a mente humana.

Qual dos recursos expressivos/artísticos apresentados no grupo (escrita, desenho, relato verbal e modelagem) você considera que contribuiu para a compreensão dos seus sonhos? Por quê?

Muitos demonstraram uma preferência pela modelagem em argila, por este recurso permitir múltiplas formas possíveis, dada a sua maleabilidade e por oferecer a visão tridimensional, a qual pôde ser discutida posteriormente, enriquecendo e ampliando os sentidos para os sonhos. 
A escrita contribuiu ao possibilitar a visualização da escolha das palavras, bem como sua repetição e ênfase. Um dos participantes comentou que a escrita é sua melhor forma de expressão, sendo assim, é o recurso que permite maior apreensão.

O desenho possibilitou o contato com variadas cores e possibilidades de representação, o que ofereceu uma nova compreensão. Também mencionaram que, no desenho, a imagem veio sem muita conceituação intelectual e que permitiu uma boa representação do sonho.

A maioria dos participantes considerou que o relato verbal foi o que mais contribuiu, visto ser capaz de promover maior conforto no relato do sonho, por ser mais pessoal e por colaborar na reflexão e análise pessoal no momento em que se conta a alguém. Também comentaram que puderam notar certas significações, quando os descreviam verbalmente, que haviam passado despercebidas anteriormente, e que podiam reviver e transmitir seus sentimentos ao contar os sonhos.

\section{Você acredita que essa experiência pode ter relevância para sua formação como} psicólogo? Por quê?

A maioria viu uma possibilidade futura de utilizar o compartilhamento de sonhos enquanto ferramenta de trabalho, dada a possibilidade de realizar abordagens semelhantes com futuros clientes/pacientes, além da probabilidade de no futuro poder trabalhar com grupos de pessoas.

Outros falaram de ter vivido uma oportunidade de estudar sonhos, conhecendo suas significações e apropriando-se do uso deste instrumento para o entendimento humano. Foi mencionado que a participação no grupo trouxe outra visão sobre sonhos, e uma nova forma de encará-los e entendê-los.

Também evidenciaram a importância do pensar em conjunto, quando era solicitado que ouvissem o sonho e compartilhassem suas impressões pessoais. Consideraram que puderam explorar a capacidade de ouvir o outro e se abrir também, bem como de se conhecer melhor e ajudar no entendimento dos outros.

Comentaram que é mais fácil aprender a discrição e o respeito à privacidade em um grupo, do que diretamente no consultório, além do cuidado para evitar invasão e desconforto, visto que estávamos trabalhando com temas bastante pessoais e sensíveis. 


\section{Qual era a sua expectativa em participar do grupo vivencial de sonhos?}

A maioria dos participantes esperava que o grupo possibilitasse uma interpretação mais formal e tradicional, em que todos pudessem expor seus sonhos para serem discutidos e interpretados verbalmente, ocorrendo, então, uma análise posterior, que oferecesse um significado mais concreto para os mesmos.

Um deles esperava, na verdade, um grupo de interpretação de sonhos e outro acreditava que haveria mais tempo analisando do que experimentando o sonho através de recursos expressivos como escrita, desenho e modelagem.

Para alguns, a expectativa era conhecer mais sobre o universo dos sonhos, buscando novas experiências e espaço para compartilhá-los com pessoas que também manifestassem o mesmo interesse.

Já, para outros, apesar da expectativa inicial não se cumprir, avaliaram a experiência vivencial no grupo como uma surpresa, considerando-o divertido, criativo e iluminador, no qual todos puderam expor seus sentimentos e falar o que sentiam sobre o sonho de todos.

\section{Antes da sua participação no grupo vivencial de sonhos como você entendia e} lidava com seus sonhos? E após ter participado do grupo, houve alguma mudança?

Para alguns os sonhos já eram considerados importantes e assim continuaram, ou adquiriram maior importância. Para outros dois participantes, que costumavam não dar muita importância, agora, passaram a se interessar mais. Um dos participantes relatou lembrar mais dos sonhos após a participação no grupo e outros dois passaram a compartilhar mais os sonhos com outras pessoas, perguntando o que lhes chama a atenção.

Também houve comentários relacionados a pensar os sonhos de um novo modo, atentando para as partes dos sonhos e para a maneira como se integram no todo. Além disso, conhecer outras formas de representação foi citado como a principal mudança por um dos participantes.

Para dois participantes não houve grandes mudanças a respeito dos sonhos, sendo que um deles percebeu alteração no que se refere à noção de como reagimos no momento de contar e expor os nossos sonhos. 


\section{Você tem alguma sugestão ou comentário?}

Em relação às sugestões, quatro sugerem encontros com duração maior, nos quais se possa focar mais nos sonhos e na discussão sobre eles, com tempo e espaço para todos falarem, permitindo que se possa ouvir e contar mais sonhos, mesmo que não sejam todos aprofundados e analisados. Há um desejo de ficar um tempo maior dedicando-se às atividades, deixando uma menor duração para a etapa de conversa posterior à experiência.

Há uma sugestão a respeito de incluir a representação teatral nos encontros e outra para que exista maior duração na atividade com argila, permitindo um aquecimento maior com o material. 


\section{NOVOS HORIZONTES}

A verdadeira viagem do descobrimento não consiste em procurar novas paisagens, mas em ver com novos olhos. ${ }^{13}$

Marcel Proust

É muito importante que a vivência de um processo de elaboração simbólica em grupo possa ser considerada como uma possibilidade viável de aprendizagem e assimilação do estudo da psicologia, visto que conciliar as duas formas de pensamento identificadas por Jung: o pensamento racional e pragmático, tão necessário e valorizado, e o pensamento criativo e afetivo dos sonhos e fantasias constitui-se como uma tarefa árdua e infinita, devido seu caráter dinâmico.

Pela possibilidade de exercício das duas formas de pensamento, o grupo vivencial pode ser considerado um recurso à formação do psicólogo, pois:

O psicólogo precisa, ele próprio, ser capaz de tal alternância entre os dois tipos de pensamento, de maneira a usufruir de sua criatividade, dispondo de mais recursos aos profissionais para estimular a mesma dinâmica nas pessoas com quem trabalha (FREITAS, 2014, p.81).

Os grupos vivenciais têm a possibilidade de mediar e facilitar o desenvolvimento destes pensamentos, além de se constituir num espaço que seja permitido reconhecer angústias, permitir as emoções de raiva e tristeza, peso e alívio, ver-se no outro, tanto em suas qualidades, quanto em suas falhas, legitimar-se em seus medos, dúvidas, vergonhas e perceber que nenhum conhecimento se faz sozinho.

E, neste ponto, o grupo vivencial se reveste de uma importância ainda maior: a possibilidade de construir um conhecimento compartilhado e embasado nas experiências pessoais, que, por sua vez, podem abrir caminho para o exercício da alteridade, considerando a vivência da pluralidade da psique e, nela, encontrando a pluralidade do outro também "[...] é precisamente o respeito pelas outras pessoas - o respeito pelo não-eu no interior profundo, bem como as necessidades do tu e do nós externos - que precisará ser enfatizado e diferenciado" (WHITMONT, 1991, p. 261).

\footnotetext{
${ }^{13}$ Disponível em https://pensador.uol.com.br/frases_de_marcel_proust/5/. Acesso em 03/02/2017.
} 
O grupo vivencial de sonhos foi considerado enquanto organismo vivo, pulsante, que traça, ao mesmo tempo que procura, o seu próprio caminho. A observação deste caminho tão singular pretendeu ser cuidadosa e direcionada para uma análise da produção simbólica. Ao descrever os encontros, as atividades, as elaborações realizadas pelos participantes e o movimento do grupo como um todo, foi possível perceber a emergência do self grupal, construído com muito acolhimento, respeito e enorme disposição pelo grupo.

Em relação ao movimento do grupo ao longo dos cinco encontros foi possível verificar a construção de um campo simbólico mobilizador, no qual:

A partir das relações interpessoais, multiplicavam-se as condições de elaboração individual e coletiva, frequentemente disparadas pela identificação nas falas compartilhadas e na compreensão de que haviam ampliado a sua própria elaboração (FREITAS; HALPERN-CHALOM, 2006).

Os roteiros e Registros do Encontro, além das conversas com a colaboradora funcionaram como um termômetro, através do qual procurei acompanhar o grupo, sentir o momento vivido pelos participantes, a fim de promover um ambiente de maior acolhimento e selecionar a utilização de recursos viabilizadores de elaboração simbólica

Também fica aqui registrada como sugestão a possibilidade de um maior número de encontros e, principalmente, com uma duração maior, por volta de duas horas ou duas horas e meia, o que facilitaria a oportunidade de compartilhamento dos sonhos por mais participantes e a criação de uma rede de associações e símbolos significativos para o grupo. A inserção de atividades dramáticas também poderia alçar o processo de elaboração simbólica a um nível importante de conscientização intelectual e também corporal e relacional, o que seria muito mobilizador de novas vivências.

A experiência de alteridade e a sua assimilação e entendimento como promotora de desenvolvimento já se deu logo no início, quando a partir da exposição do primeiro sonho, considerado forte pelo grupo, verificou-se um estímulo ao movimento de entrega e engajamento. Num primeiro momento, a entrega nos preocupou, na medida em que poderia provocar um sentimento de invasão e exposição fortes e persecutórios, inviabilizando todo o desenrolar do grupo. 
Por outro lado, percebemos que houve cuidado e respeito tanto com os próprios contornos e limites, quanto com os dos demais participantes, identificando e reconhecendo novos aspectos e facetas, acolhidas com curiosidade e respeito.

Pela consideração das falas e respostas aos registros e questionários foi notada uma resistência, a qual foi avaliada neste primeiro momento como um fator de proteção e de reconhecimento de contornos e limites, os quais precisam ser testados e avaliados a cada nova experiência. Esta constatação foi bastante tranquilizadora, pois é importante reconhecer até que ponto a exposição é adequada e até que ponto é necessário um recolhimento que vise à preservação.

Ainda em relação aos contornos e limites, foi a partir deles que se permitiu avaliar a qualidade da entrega e a quantidade da vazão ao grupo, bem como reconhecer o grau de continência e acolhimento proporcionado pelo mesmo.

Além do receio da exposição e dos julgamentos a partir das atitudes do ego onírico, foi possível observar que se iniciava a reflexão e a busca por uma atitude adequada e mais pessoal e assertiva frente às situações, sugerindo transformações na relação ego - self. É necessário o trabalho do ego em diferenciar, discriminar e, principalmente, dispor-se ao sacrifício, a partir do qual se dá o renascimento, guiado pelo self.

Também se observou o embate entre fantasia e realidade, apontado pelos sonhos e comparações com videogame e RPG, nos quais não se sofre reais consequências dos atos praticados. Começa a apresentar-se o momento de lidar por si, compreender e ressignificar o desamparo, desenvolver independência e autonomia. Possivelmente, este momento tenha eclodido a partir do encontro com uma forte emoção, a qual se deu no terceiro encontro, e esta, à semelhança do que ocorreu no sonho, situa-se na própria faculdade e traz a dor e o choro reparador pela separação, e o grupo como um espaço legítimo para sentir, chorar, descobrir e explorar.

Assim, constituiu-se um campo para perceber, na prática, que, nos constituímos e caminhamos em nosso percurso de individuação a partir das relações que escolhemos, estabelecemos e vivemos. A experiência de alteridade é sempre marcada e entremeada pelo universal e pessoal, parâmetros sempre incluídos nos conceitos de Jung.

Além disso, foram notados nos sonhos temas de perseguição, desproteção, solidão, desamparo, morte, mas também movimentos criativos, de união e assimilação do novo. Tais temas parecem situar a experiência de chegada à faculdade de psicologia como um processo 
de iniciação, em que se fazem necessárias transformações, as quais incluem também certas perdas importantes.

Pode ser válido pensar nas diversas transformações vivenciadas pelos estudantes que se encontram nesta etapa, momento no qual certas separações acabam sendo necessárias e importantes, inerentes ao próprio momento de entrada na faculdade.

De um modo geral, sobre a temática dos sonhos, pode-se perceber que no primeiro encontro foram trazidos sonhos que se relacionavam à morte, perda, solidão, angústia, separação e uma ansiedade a respeito de algo terrível que se aproxima, que nos sonhos expressou-se como saber que vai morrer, ser atingido por um tiro na cabeça, presenciar, sozinho, a formação de uma grande tempestade. Por outro lado, alguns sonhos trouxeram a possibilidade de se vivenciar algo novo, aludindo ao momento de fim e início de um novo ciclo, como ir para o outro lado do mundo e começar uma história menos triste ou guiar a mãe até a faculdade porque já se sabe o caminho, mas ainda não se é possível dirigir sozinha.

Para Hendersen (2008) em períodos críticos do desenvolvimento humano, o arquétipo da iniciação é fortemente ativado, justamente para oferecer sentido à fase de transição que se aproxima. Buscar ou aproximar-se desse sentido no contexto de um grupo vivencial é importante, pois:

Há a possibilidade, privilegiada de se experienciar mais diretamente certos símbolos, inclusive os que se referem a situações transitórias ou circunstanciais ao longo da vida, mas nem por isso deixam de ter uma dimensão profunda e ética, e de experienciar empatia, simpatia ou antipatia, confronto, solidariedade, companheirismo e interlocução (FREITAS, 2009, p. 82).

Os sonhos trazidos em seguida, apresentam uma temática mais heroica, que nos leva a pensar em conexões com a jornada do herói. De acordo com Hendersen (2008) o mito do herói se mostra a partir da necessidade de diferenciação psíquica, em que o ego precisa desenvolver sua autonomia.

Existem tarefas heroicas a serem realizadas. É possível perceber essa temática nos sonhos em que se pede auxílio à mãe e ao namorado, mas é preciso lutar sozinha contra o urso; quando se impõe a necessidade de falar outras línguas e compreendê-las; ou se está num grande salão sem teto, cheio de colunas dispostas em simetria, com uma fonte d'agua ao 
fundo, e sente-se que está em uma grande jornada ou missão; ou, ainda, no sonho em que é preciso salvar a mãe num ambiente em que há pilares de metal em uma caverna de lava.

O urso nos leva à figura de Ártemis, a deusa da caça e das provas iniciáticas. Conforme Freitas (1995), Ártemis era rodeada por companheiras que comumente se metamorfoseavam em ursas. Além disso "o urso é considerado o mais selvagem dos animais e, por outro lado, semelhante ao homem, na postura do parto, na forma dos pés, na posição ereta, na alimentação onívora" (FREITAS, 1995, p. 175).

Há também a presença do elemento fogo, na lava e na fogueira, a qual aparece em um dos sonhos e encontra-se no centro, rodeada por bancos, que se permanecem à medida que os cenários que o sonhador presenciam vão se transformando. É possível voltar à operação alquímica calcinatio, considerada por muitos estudiosos como o primeiro momento do desenvolvimento psíquico, que, agora, também envolve a sublimatio, na transformação das fagulhas em borboletas, indicando o próprio movimento espiralado do self e da individuação.

Os últimos sonhos dos encontros do grupo mostraram outro momento, relativo às questões de adaptação, equilíbrio, assimilação e competência, envolvendo estranhamento, integração e aquisição de responsabilidades.

O último encontro do grupo antecedeu a primeira prova do ano e nos sonhos também se mostrou a temática escolar, com os colegas do colégio e do cursinho misturados aos novos colegas da faculdade; a dificuldade para encontrar o local do vestibular, situado num ambiente enorme, com colegas e professores anteriores que não ajudavam a encontrar a sala da prova; também aparece o estar num local estranho, mas parecido com a faculdade, em que uma luta logo se iniciaria, mas não se podia preparar-se para ela.

Pode-se imaginar uma busca por encontrar-se na faculdade, achar o seu lugar, a sua turma, adaptar-se e assimilar o que se apresenta e, neste processo, aparece o estranhamento, o novo, a imensidão e a sensação de não se sentir preparado.

Em um dos sonhos, há um indicativo de integração, equilíbrio e movimento e do trabalho para receber, assimilar e equilibrar: existe uma torre de pessoas na praia e o sonhador faz parte dela, mas quando percebe o perigo, ele volta, e assim, a torre cede e se desfaz.

Também aparece o sentimento de buscar algo com grande responsabilidade e, assim, deparar-se com uma menina escalando e subindo, talvez numa indicação de um processo de desenvolvimento. Assim, como a torre, há um direcionamento para o alto. 
Também surge o estranhamento, por receber presentes em uma festa de aniversário que não é sua e um impedimento quanto a falar com uma pessoa que já fez parte da vida, mas que agora tem outros interesses, outras vontades, talvez aludindo a sensação de novidade como sendo diferente, estrangeira, exterior ao ego, ainda não assimilada.

Já em outro sonho, há a integração de personagens de diferentes desenhos animados, que encontraram uma coerência e, juntos, demonstram os sentimentos por aqueles que morreram e por aqueles que ainda permanecem, em um clima de paz, o que pode nos levar a pensar em um momento de assimilação das perdas e ganhos deste momento e da aceitação do que é diverso.

Novamente, a mãe reaparece em um sonho em que a sonhadora é perseguida por pessoas que se assemelham a lobos, e fica indiferente ao chamado de ajuda da filha, lembrando o sonho em que há o pedido de ajuda para enfrentar o urso. Em outro sonho, a mãe morre em decorrência de um incêndio e seu possível corpo encontra-se numa canoa percorrendo um rio, o qual seu filho segue, margeando, porém devido a obstáculos naturais não pode constatar se realmente é o corpo da mãe.

De algum modo, os sonhos com as mães parecem indicar o momento de transformação da relação materna e do sentimento de desamparo provocado. Talvez por temer o novo, e pela grande probabilidade de frustração e erros ao iniciarem este caminho com seus próprios pés e seus próprios sonhos.

Finalmente, reaparece a fogueira, também ao centro e rodeada por bancos e pessoas que conversam, juntamente com a presença de Platão, e contam como fizeram a passagem, como morreram e vieram para esse novo lugar. Este sonho pode indicar a possibilidade de experimentar a vida após a morte, consagrando o ciclo de morte e renascimento deste momento de iniciação na entrada na faculdade. E o sonho também parece dizer que há pessoas mais experientes que podem ensinar a respeito do desconhecido, aplacando angústias.

Assim, foi possível perceber o alcance do grupo vivencial de sonhos ao favorecer a participação num contexto simbólico, onde foi permitido falar da experiência e fazer-se a partir dela:

Salta à vista também, nos grupos vivenciais, quanto a matéria e suas possibilidades expressivas podem ser continentes para diferentes processos, projeções e elaborações simbólicas, e quanto ela, em autonomia e criatividade peculiares, pode escapar ao controle da 
consciência e fazer emergir um símbolo que a confronte (FREITAS, 2014, p.95).

Pensando nesta potencialidade de conter e também transformar aquilo que se apresenta, o grupo vivencial de sonhos pode contribuir para uma perspectiva de alteridade e das implicações pessoais na tomada de conhecimento do fazer em psicologia, múltiplo e inesgotável. 


\title{
7. CONSIDERAÇÕES FINAIS
}

\author{
A grande aventura do homem moderno não consiste apenas \\ em explorar o mundo exterior, mas muito mais em penetrar \\ nas profundezas da alma. \\ Guggenbühl-Craig, 2008.
}

O desenvolver desta dissertação trouxe dificuldades no que se refere a encontrar modelos existentes que pudessem dar conta de abarcar o todo da vivência simbólica ocorrida no grupo, em termos do movimento grupal e da elaboração simbólica dos sonhos e encontros a partir do uso de recursos expressivos.

Ao finalizá-la, encontrei esta citação, que talvez tenha procurado durante todo o processo:

Logo percebi que era correto tomar, como base de interpretação, os sonhos tais como se apresentam. Eles são o fato do qual devemos partir. Naturalmente meu 'método' engendrou uma variedade de aspectos quase inabrangível. A necessidade de um critério tornou-se cada vez mais premente, ou melhor, a urgência de uma orientação inicial pelo menos provisória (JUNG, 2016, p. 177).

Tanto os símbolos dos sonhos, quanto a forma de trabalho, os grupos vivenciais, são inesgotáveis, e permitem múltiplas e diferentes perspectivas de abordagem, sendo que foi preciso selecionar os pontos e temas que mais saltaram à vista, à semelhança de uma orientação inicial pelo menos provisória.

A psicologia analítica de Jung e o entendimento e manejo de grupo oferecidos pelo psicodrama ofereceram as bases teóricas e práticas, o que mostra a necessidade de pesquisas maiores e mais aprofundadas sobre este campo em comum, de abrangência das duas vertentes teóricas.

Assim como não conseguimos lembrar de todos os nossos sonhos, todas as noites e em detalhes, não foi possível compartilhar e aprofundar todos os sonhos que compuseram o campo do grupo vivencial, porém encontram-se aqui registrados e colaboram para uma possível futura retomada. Encontramos embasamento em Hall quando argumenta que: 
Mesmo quando os sonhos não são interpretados, eles parecem às vezes ter um profundo efeito sobre a consciência vigil. Através da observação do impacto de sonhos não analisados, é possível inferir que, mesmo quando não recordados, os sonhos são parte vital da vida total da psique (HALL, 2007, p. 33).

A respeito da formação do psicólogo podemos notar que esta poderia ser aprofundada através de grupos vivenciais que pudessem mobilizar conteúdos pessoais para, assim, articulálos com a conceituação teórica e promover uma aprendizagem pautada numa experiência, que pudesse ser mobilizadora e transformadora, entendendo que:

A situação de ensino-aprendizagem visa, mais do que a transmissão de informações, sua assimilação pela personalidade, que assim vai aprendendo a aprender e vai estruturando uma persona profissional persona entendida no sentido amplo, como função paraegóica, expressiva, comunicadora e estruturante da personalidade (FREITAS, 1990, p. 97).

Em relação à construção da persona profissional, é importante retomar as considerações sobre o arquétipo do curador-ferido, entendendo que a prática clínica do psicólogo é permeada pelo contato com a ferida, dor, doença e sofrimento e pela busca da cura e do cuidado, dela decorrendo uma nova perspectiva sobre a vida e uma possibilidade de renascimento para o ego.

Guggenbühl-Craig (2008) pontua a necessidade de o terapeuta estar envolvido em situações e relacionamentos que o engajem, que despertem seu potencial e desenvolvimento pessoal, pois "sua eficácia depende em grande medida do desenvolvimento de sua própria psique" (p.136). Desse modo, considera que o psicólogo transite pelos polos do arquétipo do curador-ferido, pois para aqueles que o arquétipo não se cindiu:

Estes, por assim dizer, estão sempre sendo analisados e iluminados por seus pacientes. Esse tipo de analista reconhece que as dificuldades do paciente constelam as suas próprias, e vice-versa; trabalha, portanto, não apenas com o paciente, mas consigo próprio. Ele é, para sempre, terapeuta e paciente (GUGGENBÜHL-CRAIG, 2008, p.117).

É de grande importância que o psicólogo possa reconhecer as dificuldades do paciente em si próprio e procurar formas de desenvolvê-las para poder então voltar-se e relacionar-se com o paciente de forma a permitir a constelação do pólo curador. Assim, recorrer ao 
trabalho com seus próprios sonhos pode revelar-se como forma de manter o contato com os conteúdos inconscientes de sua psique.

Além disso, ter contato com seu inconsciente e seus conteúdos e reconhecê-los, identificá-los e desenvolvê-los em um contexto grupal, ampliando assim a sua dimensão, permite elaboração e acolhimento, ao vivenciar o arquétipo do curador-ferido. Assim, percebemos que:

O trabalho com sonhos tem muito a contribuir para a formação do psicólogo. Permite a iniciação à linguagem simbólica, de uma maneira pessoal e compartilhada, a abertura para trabalhos dessa natureza com os próprios pacientes, e a construção de uma maneira de assimilar aspectos teóricos à experiência vivida (FREITAS, 2014, p. 102).

Vale mencionar também a observação de que os participantes associaram, com bastante frequência, a natureza e o conteúdo dos sonhos com videogames e RPG, o que nos leva a pensar na relação entre inconsciente, símbolo e virtualidade, podendo motivar novas e relevantes pesquisas acerca da subjetividade que vai se estruturando na virtualidade e as consequências para o desenvolvimento do ego.

Seria interessante consultar os participantes deste grupo vivencial de sonhos no momento em que estiverem prestes a finalizar o curso, perfazendo, assim, um estudo longitudinal a fim de compreender a finalização de um percurso que se encontra aqui registrado, além de outros aspectos relacionados à construção da persona profissional de psicólogo.

Há também a possibilidade de realizar novos grupos com estudantes provenientes de outros anos e de faculdades públicas e privadas de psicologia, além de outros cursos de graduação e continuar a pesquisa com sonhos em um nível simbólico, ou mesmo identificar os sonhos e as aspirações relacionadas à escolha profissional. Além disso, esta dissertação pode vir a ajudar na consideração do uso e estudo de recursos expressivos e vivenciais na grade curricular dos cursos de psicologia, promovendo um aprendizado permeado pela vivência.

Da mesma forma que iniciei a dissertação recorrendo à minha experiência, à época como estudante de psicologia, termino-a, agora, como estudante e psicóloga, mestre e aprendiz, curadora e ferida, com toda a minha alma. 


\section{REFERÊNCIAS}

ANDRESEN, S.M.B. Poesia. In: Obra poética. Lisboa: Caminho, 2011.

BONDIA, J. L. Notas sobre a experiência e o saber de experiência. Revista Brasileira de Educação [online]. 2002, n.19, pp.20-28. $\quad$ Disponível em <http://www.scielo.br/pdf/rbedu/n19/n19a02.pdf> Acesso em 02 Fev. 2017.

CARVAlHO, A. C.; BACCHI, C. KOVÁCS, M. J. A formação de psicólogos: um serviço a serviço de alunos In: Aconselhamento psicológico centrado na pessoa: novos desafios. MORATO, H.T.P. (org.). São Paulo: Casa do Psicólogo, 1997. 2a ed, p. 235-249.

EDINGER, E. F. Psicoterapia e alquimia. Junguiana, São Paulo, 1984, n.2, p. 43-68.

FREITAS, L.V.; AZEVEDO, L.; VILHENA, M.A.F. A cabeça-voraz: vivência simbólica de um mito amazônico. Junguiana, São Paulo, 2000. v.18, p. 7-17.

A Máscara e a palavra: exploração da persona em grupos vivenciais. 1995. 257f. Tese (Doutorado em Psicologia) - Instituto de Psicologia, Universidade de São Paulo, São Paulo.

A Psicoterapia como um rito de iniciação. Estudo sobre o campo simbólico através de sonhos relacionados no self terapêutico. 1987. 131f. Dissertação (Mestrado em Psicologia Clínica) - Instituto de Psicologia, Universidade de São Paulo, São Paulo.

Grupos vivenciais sob uma perspectiva junguiana. Psicologia USP, São Paulo, v.16, p.45-69, n.3, 2005.

; HALPERN-CHALOM, M. Mitos, contos e recursos diversos no self grupal. Hermes, São Paulo, v. 11, p. 38-45, 2006.

O arquétipo do mestre aprendiz: considerações sobre a vivência. Junguiana, São Paulo, v.8, p. 72-99, 1990.

O calor e a luz de Héstia: sua presença nos grupos vivenciais. Cadernos de Educação UNIC, São Paulo, p.45-69, 2005b. Edição Especial.

O sonho na psicoterapia, nos grupos vivenciais e na formação do psicólogo: iniciação e linguagem facilitadora. In: FARIA, D.L., FREITAS, L.V., GALLBACH, R.M. 
(orgs.). Sonhos na psicologia junguiana: novas perspectivas no contexto brasileiro. São Paulo: Paulus, 2014, p. 79-105.

Panorama dos conceitos junguianos. In: ALBERTINI, P.; FREITAS, L.V. (orgs.). Jung e Reich: articulando conceitos e práticas. São Paulo: Guanabara Koogan, 2009, p. 16-31.

. Processo de "Grupação"? Reflexões sobre o Potencial dos Grupos Vivenciais. In: IV Congreso Latinoamericano de Psicologia Junguiana, 2006, Punta del Este. Anales del IV Congreso Latinoamericano de Psicologia Junguiana. Montevideo: Imprenta Grega, 2006, p. 369-373.

GALLBACH, M.R. Aprendendo com os Sonhos. São Paulo: Paulus, 2000.

GUGGEnBÜHL- CRAIG, A. O Abuso do Poder na Psicoterapia: e na medicina, serviço social, sacerdócio e magistério. São Paulo: Paulus, 2008, $2^{\text {a }}$ ed.

HALL, J.A. Jung e a interpretação dos sonhos: manual de teoria e prática. São Paulo: Cultrix, 2007.

HARK, H. Léxico dos Conceitos Junguianos Fundamentais a partir dos originais de Carl G. Jung. São Paulo: Edições Loyola, 2000.

HENDERSON, J.L. O arquétipo de iniciação. In: JUNG, C.G. O homem e seus símbolos. Rio de Janeiro: Nova Fronteira, 2008. p. 167-177.

HUMBERT, E.G. Jung. São Paulo: Summus, 1985.

JACOBI, J. Complexo, arquétipo e símbolo na Psicologia de C. G. Jung. São Paulo: Cultrix, 1975.

JUNG, G. C. A natureza da psique. Petrópolis: Vozes, 2000.

A prática da psicoterapia. Petrópolis: Vozes, 1997.

. Memórias, sonhos e reflexões. Rio de Janeiro: Nova Fronteira: 2016.

Os arquétipos e o inconsciente coletivo. Petrópolis: Vozes, 2000. 
O desenvolvimento da personalidade. Petrópolis: Vozes, 1986.

O eu e o inconsciente. Petrópolis: Vozes, 2015

. O homem e seus símbolos. Rio de Janeiro: Nova Fronteira, 2008.

. Símbolos da transformação: análise dos prelúdios de uma esquizofrenia.

Petrópolis: Vozes, 2013.

. Tipos Psicológicos. São Paulo: Zahar, 1967.

KAST, V. Sonhos: a linguagem enigmática do inconsciente. Petrópolis: Vozes, 2010.

KNOBEL, A.M; ALVES, L.F.R. Estratégias de direção grupal e identificação do agente protagônico nos grupos socioeducativos. In: MARRA, M.M.; FLEURY, H. J. (orgs.). Grupos - intervenção socioeducativa e método sociopsicodramático. São Paulo: Ágora, 2008. p. 69-91.

KOVÁCS, M.J. Um estudo sobre o medo da morte em estudantes universitários das áreas de saúde, humanas e exatas. 1985. 135f. Dissertação (Mestrado em Psicologia) Instituto de Psicologia, Universidade de São Paulo, São Paulo.

LAWRENCE, W.G. O sentido social dos sonhos: a técnica da matriz. São Paulo: Summus, 2010.

MELLICK, J. The art of dreaming: tools for creative dream work. Conari Press: Berkley, California, 2001

MURRAY, S. Consciência solar, consciência lunar: ensaio sobre os fundamentos psicológicos da moralidade, da legalidade e da noção de justiça. São Paulo: Paulus, 1998.

NERY, M.P. Grupos e intervenção em conflitos. São Paulo: Ágora, 2010.

PARISI, S. Separação Amorosa e Individuação Feminina: uma abordagem em grupo de mulheres no enfoque da psicologia analítica. 2009. 272f. Tese (Doutorado em Psicologia) Instituto de Psicologia, Universidade de São Paulo, São Paulo. 
PENNA, E.M. D.. O Paradigma Junguiano no contexto da metodologia qualitativa de pesquisa. Psicologia USP, v. 16(3), p. 71-94, 2005.

RODRIGUES, R. Teatro de reprise: improvisando com e para grupos. São Paulo: Ágora, 2016.

WHITMONT, E.C. A busca do símbolo: conceitos básicos de Psicologia Analítica. Editora: Cultrix, 1969.

WHITMONT, E. C. O retorno da Deusa. São Paulo: Summus, 1991.

WOLFF, J.R.A.S. Onirodrama: contribuição ao estudo dos sonhos em psicoterapia psicossomática. 1981. Dissertação (Mestrado em Medicina) - Departamento de Psiquiatria, Universidade de São Paulo, São Paulo. 
9. ANEXOS

ANEXO A - CONVITE PARA PARTICIPAÇÃO

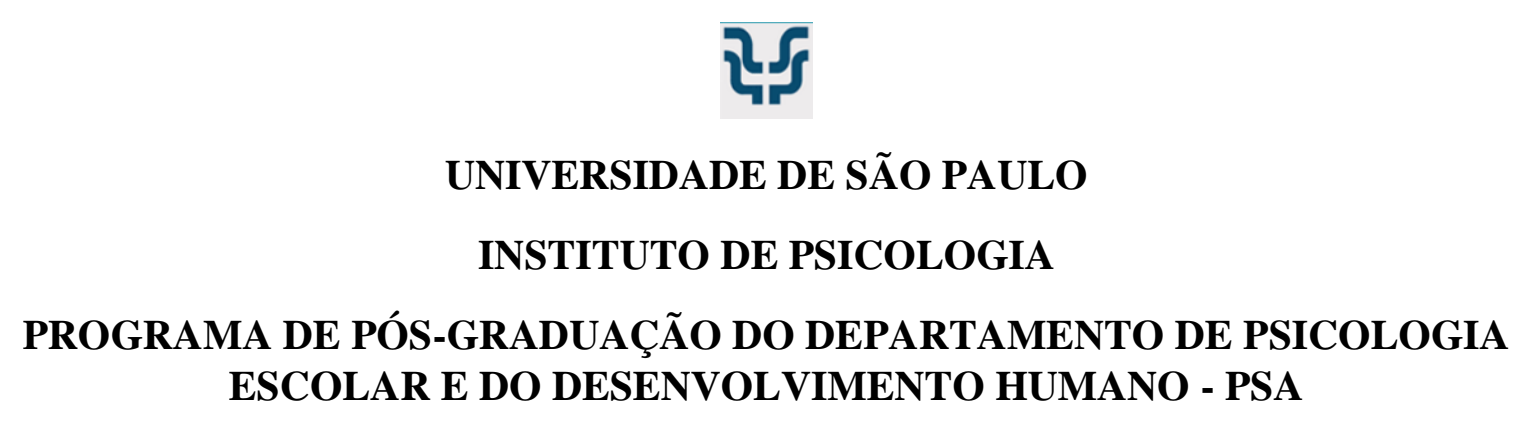

Grupos Vivenciais de Sonhos com Estudantes de Psicologia

Convidamos os estudantes de Psicologia do $1^{\circ}$ ano de Graduação em Psicologia na USP para participar da pesquisa de Mestrado: “Grupos Vivenciais de Sonhos com Estudantes de Psicologia", que procura favorecer o compartilhamento de sonhos em grupo vivencial.

Através do grupo, vamos proporcionar o compartilhamento de sonhos e o uso de diversos recursos expressivos e artísticos com a finalidade de obter uma nova perspectiva acerca da linguagem dos sonhos em um espaço de acolhimento e valorização da experiência de cada participante.

Serão realizados até cinco encontros, sendo um por semana, no Ateliê do CEIP (Bloco D) às 2as feiras, das 14h às 15h30, com início previsto para 09/03/15.

Para confirmar seu interesse ou para maiores informações entre em contato pelo email: grupovivencialdesonhos@gmail.com

Esperamos vocês!

Pauline de Mello Martines (Mestranda) Profa. Dra. Laura Villares de Freitas (Orientadora) 


\title{
ANEXO B - TERMO DE CONSENTIMENTO LIVRE E ESCLARECIDO
}

\author{
INSTITUTO DE PSICOLOGIA DA UNIVERSIDADE DE SÃO PAULO
}

\author{
Programa de Pós-Graduação em Psicologia Escolar e do Desenvolvimento Humano
}

\section{TERMO DE CONSENTIMENTO LIVRE E ESCLARECIDO}

Você está sendo convidado (a) a participar da pesquisa de mestrado "Grupos Vivenciais de Sonhos com Estudantes de Psicologia", de responsabilidade da pesquisadora Pauline de Mello Martines, sob orientação da Prof. Dra. Laura Villares de Freitas (Av. Prof. Mello Moraes, 1721 Bloco A - sala 184 / telefone: (11) 3845-4526 / e-mail: lauvfrei@usp.br).

A participação nesta pesquisa consistirá em comparecer aos encontros dos grupos vivenciais, sendo um deles composto apenas por alunos do $1^{\circ}$ ano de graduação e o outro composto apenas por alunos do $5^{\circ}$ ano de graduação em Psicologia na USP. Os grupos vivenciais terão a duração de até 5 encontros semanais no Ateliê do CEIP (Centro Escola do Instituto de Psicologia). Os encontros se pautarão pelo compartilhamento de sonhos e consequente utilização de recursos expressivos e artísticos com a finalidade de se obter uma nova perspectiva acerca dos mesmos.

Durante a realização do grupo vivencial, o(a) participante contará com apoio e cuidado por parte da pesquisadora e, se porventura vier a sentir algum desconforto, o mesmo poderá compartilhá-lo no grupo, que o acolherá, ou solicitar uma conversa posterior para compreensão e eventual encaminhamento do que tenha motivado o desconforto.

A participação nesta pesquisa é totalmente voluntária, podendo ser interrompida a qualquer momento. Cuidados éticos serão tomados e serão omitidas todas as informações que permitiriam identificá-lo(a), garantindo o sigilo. Além disso, sua participação não implica em nenhum ônus financeiro para nenhuma parte. O presente Termo de Consentimento Livre e Esclarecido foi elaborado em duas vias, uma delas ficará com o participante e a outra com a pesquisadora.

Quaisquer dúvidas relativas à pesquisa poderão ser esclarecidas pela pesquisadora Pauline Martines (e-mail: pauline.martines@usp.br / celular: 9 9113.7692), ou junto ao laboratório que dará suporte à pesquisa (Laboratório de Estudos da Personalidade - Av. Prof. Mello Moraes, 1721 - Bloco D, sala 232 - lep@usp.br). Para dúvidas com relação a ética da pesquisa, disponibilizo os contatos do Comitê de Ética em Pesquisa com Seres Humanos do Instituto de Psicologia da Universidade de São Paulo (Av. Prof. Mello Moraes, 1721 - Bloco G, $2^{\circ}$ andar, sala 27).

São Paulo, de de 2015 .

$\mathrm{Eu}$, , declaro ter sido informado dos procedimentos da presente pesquisa e concordo em participar voluntariamente do grupo vivencial de sonhos acima descrito.

RG: E-mail:

Assinatura:

Pesquisadora:

Assinatura: 


\section{ANEXO C: RESULTADOS DO $1^{\circ}$ ENCONTRO}

Registro do encontro:

Este encontro, em três palavras, foi...

- Acolhimento, Abertura, Curiosidade

- Exposição, Conforto, Sensação

- Interesse no assunto, Discussão e debate, Produtivo

- Animação, Perspectiva, Sugestão

- Lúdico, Infância, Relaxamento

- Confiança, Entrega, Perspectivas

- Esquisito, Diferente, Desconfortável

- Curiosidade, Abertura, Inserção

- Reflexivo, Memória, Guerra

- Obstrução, Receio, Descrença

- Espontaneidade, Tranquilidade, Confiança

- Calma, Reflexão, Autoconhecimento 


\section{ANEXO D: SONHOS ESCRITOS NO $1^{\circ}$ ENCONTRO}

"Uma vez eu sonhei que estava num salão branco e bem alto eu que tinha 5 anos vestida com um vestido ficava bem no meio e olhava pra cima, quando eu olhei vi um pequeno chinês, um menino, e ele estava vestido de vermelho e dourado, ele era careca e possuía um chapéu, ele andava e vinha até mim, quando chegava perto sumia e reaparecia em outro local como se tivesse se teletransportando muitas vezes. E sumiu".

"Estava no C.A. (Centro Acadêmico) conversando com alguém, ouço o barulho de tiros e vejo que pessoas caem ao meu redor, percebo que fui atingido na cabeça e, racionalmente, sinto como é estar morto, não que necessariamente seja um sentimento ruim, foi como vivenciar uma nova experiência, não consigo colocar em palavras o sentido que me fez durante o sonho".

"Sonhei que estava aqui no instituto de Psicologia, num dia de aulas normal, mas dentro de uma estranheza indefinivel que pairava sobre o que eu fazia e sobre os espaços por onde caminhava, que não me permitiam saber com certeza quem eram as outras pessoas e o lugar onde eu estava. Mas com uma certeza incerta, de sonhos, sabia que era o IP. Subindo uma escada eu subitamente lembrei uma cena de separação entre duas pessoas apaixonadas, e imediatamente pensei numa dor guardada há muito, associada a uma pessoa que conheço, e que naquela hora eu pude aliviar através de um choro profundo, importante para aquele momento".

"Estamos, meu pai e eu, no carro da minha madrasta, pegando a estrada que sempre costumamos pegar para ir ao interior. Eu olho para o meu pai e digo "o engraçado dos acidentes de carro é que você nunca sabe quando eles vão acontecer". Um caminhão passa buzinando ao nosso lado, meu pai dá uma guinada para a esquerda e caímos da ponte direto em um lago. Enquanto o carro cai e se enche de água, tento tirar o cinto, pensando "eu e minha grande boca". O cinto não solta e fico irritada por não ter uma faca para cortar o cinto. Aceito a derrota e espero a água chegar ao meu rosto, mas acordo antes disso (sem ar e agradecendo que foi apenas um sonho) ".

"Lembro de um oficial russo dizendo algo para vários soldados. Eu era um deles. Eu sabia que era um soldado do Exército Vermelho soviético, e estava lutando contra os nazistas em Stalingrado. Logo depois me vi em uma casa de vários andares, e ela estava bastante destruída pelas bombas alemãs. Alguns outros soldados russos estavam comigo, e estávamos todos com medo. Vira e mexe um soldado era baleado. Então eu peguei meu rifle, e com a visão avermelhada de raiva, sai por um dos buracos na parede, que dava em um cano largo. Minhas pernas estavam tremendo, e eu queimava de raiva mesmo estando no meio da neve. Depois de atingir o segundo nazista em vista, eu sabia que iria morrer; a chuva veio, e outros soviéticos vieram ajudar. Eu esfaqueei um alemão com minha baioneta, sentindo seus ossos quebrando. Depois estava em linha com outros soldados aliados, e por um surto de raiva esfaqueei um deles. Ninguém sabia o porquê, e só senti culpa depois. Todos estavam assustados com isso".

"Era um sonho em tons de fábula - não é incomum que eu sonhe um desses. Eu era um ouriço, e o sonho começa à noite, nas margens de um lago, eu estou entre os arbustos. É uma noite de luar e vem chegando pela água um cisne, que nada em minha direção. $O$ cisne vem até mim reclamar, pois suas penas estão todas espetadas por espinhos negros e pontiagudos. Eu discuto que aqueles não são os espinhos de um ouriço, mas de um porco-espinho. O cisne é fêmea e diz que seu nome é Jeine; e Jeine está muito brava. O que me lembro depois é que já é dia, eu estou pelos campos, retirando chumaços de pelos de carneiros de uma cerca de arame farpado, e guardando estes pelos em uma cesta. Em algum momento acontece uma forte emoção; eu ainda sou um ouriço, mas estou aflito porque tenho um amigo - humano - que está sendo enfeitiçado por um grupo de fotógrafos e eles querem que ele vá embora para o outro lado do mundo com eles, começar uma nova história, menos triste.Indignado, eu grito: 'Mas Jeine é um cisne e até ela tem espinhos!’.

"Quando eu era criança tive um sonho marcante, apesar de muito estranho. Sonhei que olhei pela janela do meu apartamento e vi - no espaço de lazer do prédio - uma fonte que na realidade não existia, e nessa fonte havia um dinossauro correndo em círculos. O nosso zelador corria atrás do dinossauro com uma rede de pegar borboletas. Apesar da comicidade gritante da cena o meu eu de 
pouco mais de 9 anos sentiu apenas medo. Corri para longe da janela. De repente estava com meus pais, minha irmã e uma desconhecida no hall do nosso andar. Nós estávamos fugindo de algo. Quando dei por mim dois de meus familiares. Não sei por que, mas isso só poderia significar algo horrivel. Creio que acordei".

"Eu estava no meu apartamento antigo, onde o pequeno corredor dava, à direita pro banheiro, em frente pro quarto dos meus pais e à esquerda pro meu. Quando cheguei no corredor tinha uma fila de 3 pessoas. Elas estavam esperando pra ver uma "cigana" que estava no meu quarto e que lhes contaria o seu futuro. Eu achei estranho. Mas resolvi ficar na fila e ver quem era. Quando eu finalmente entrei no meu quarto vi uma figura grande e nebulosa flutuando numa parte vazia do meu quarto. Era Nossa Senhora Aparecida, com aquele manto azul escuro. Nunca fui muito religiosa mas via ela como uma "amiga" (imaginária?)Aí perguntei algo que ia acontecer. Ela não respondeu diretamente para mim - eu nem via a sua face - mas na parede do quarto surgiram símbolos grandes e nebulosos, em roxo. Não entendia eles mas soube que a mensagem é que eu ia perder um anel de florzinha que eu tinha ganhado e amava (tinha uns 6 anos na época). Acabou o sonho. No dia seguinte eu fui com ele pra escola e perdi ): ".

"Faz um tempo já (creio que uns anos...) que eu tive um sonho que eu não lembro direito o que aconteceu, só lembro que quando eu acordei a sensação que eu tive era muito ruim (angustiante até). Eu tava na minha antiga escola, perto da horta que tinha lá e do nada o tempo, que estava claro, fechou (estilo temporal) e eu lembro que ficou frio e que quando eu olhei ao meu redor eu tava sozinha, mas eu não consigo lembrar se antes do tempo mudar eu estava só ou não. Eu tentei correr para um dos lados, pra ir para algum lugar por causa do tempo, parecia que eu não conseguia sair daquela região que eu estava. Eu só lembro que depois disso eu ouvia uns barulhos (carros, pessoas conversando, crianças falando) e o sonho terminava".

"Sonhei que minha mãe me trazia à faculdade; eu sabia o caminho e, portanto, a guiei até o Instituto de Psicologia. Chegando à faculdade, entrei em um bloco e lá estavam meus amigos do Ensino Médio juntamente a alguns amigos da faculdade. Também havia muitos mosquitos e o ambiente tinha um estilo meio safari/aventura. Conversei com meus amigos sobre a vida... Acordei com o despertador".

“- Imagem de um céu ao amanhecer.

- Voz do meu avô (que tinha morrido fazia algumas semanas):

- Eu estou bem; acho que isso é o céu, mas está meio frio.

- Luz branca.

- Acorda".

"Local: Próximo da minha casa

Há mais ou menos uns 200 metros da minha há um morro não muito íngreme usado para o plantio de grãos. No momento do sonho a colheita do milho já tinha ocorrido e haviam os "tocos" da planta, as palhas e alguns trechos com a terra marrom e seca exposta. Mais ou menos no meio do morro há uma estrada (no sentido de subida). Nessa estrada haviam pedras grandes e pequenas, além da terra mais fina característica de estrada de chão.

Ação: Recordo de estar em um ponto do morro de frente para a descida do mesmo. Era um momento de pôr-do-sol. Eu desci correndo, abri os braços e comecei a voar, voei muito pouco e em seguida caí, ainda com os braços abertos.

Acordei com a sensação das pedras entrando no meu peito e a poeira no meu rosto.

Sentia-me muito mal logo após o sonho.

Sonho muito forte e com muitas repetições.

Idade: Entre 8 e 12 anos". 


\section{ANEXO E: RESULTADOS DO $2^{\circ}$ ENCONTRO}

Registro do encontro:

\section{Este encontro, em três palavras, foi...}

- "Esforço, paciência, atenção";

- "Calma, imersão, lembrança";

- "Calmo, bom, esclarecedor";

- "Receio, dúvida, conflito";

- "Zen, calmo, divertido";

- "Surpreendente, relaxante, divertido";

- "Pesado, incômodo, abertura";

- "Viagem, concepção, imagética",

- "Calor, sangue e frieza";

- "Complexo, permanente, difícil";

- "Relaxante, tranquilo, reflexivo";

- "Relaxante, estimulante, autoconhecimento";

- "Tentativa, explorar, reexperimentar".

\section{Experimentar o meu sonho a partir dessa atividade...}

- "Pelo esforço de tentar voltar ao estado de sonho, que me é um pouco perturbador, a atividade foi um esforço pessoal e consciente para estar presente durante o relato dos meus colegas";

- "Foi um desafio de conseguir expressar em um desenho um sonho que despertou diversos sentimentos";

- "Foi diferente, mas estimulante";

- "É muito legal”,

- "Bem interessante, ver como o meu corpo reagia ao meu sonho";

- "Foi interessante, pois fui obrigada a buscar meios visuais objetivos de representar sentimentos subjetivos. Com isso pude desenvolver uma nova perspectiva sobre meu sonho";

- "Foi forte. Revivi os sentimentos ao compartilhá-lo. Foi bom extravasar no desenho";

- "O relaxamento anterior à atividade em si foi extremamente producente, e inspirador. Uma forte torrente de imagens (e também sons, sensações) pode ser recuperada antes de se desenhar o sonho. E fazer o desenho não foi exatamente difícil, mas a imagem no papel não conseguiu captar por inteiro o impacto do sonho";

- "Foi estranho, já que o sonho não concorda muito com meus sentimentos. Praticamente só senti calor e relembrei o que senti na ocasião, mas não a revivi";

- "Fez com que eu percebesse mais aspectos do sonho e formar uma imagem mais nítida de uma cena marcante";

- "Foi divertido tentar expressar pelo desenho e criar relações entre o sentido e o sonhado (as imagens) "; 
- "Foi uma novidade, nunca havia relacionado sonhos com alguma parte do meu corpo, me ajudou na reflexão e percebi relações que não havia feito antes";

- "Foi diferente. Nunca tinha tentado desenhar um sonho. Apesar do sonho que eu desenhei não foi tão "forte”, foi diferente reviver as sensações do sonho".

\section{O que levo daqui...}

- "Um convite à reflexão e imersão nos meus sonhos";

- "Uma imagem do meu sonho, que antes não tinha”;

- "Vontade de voltar";

- "A tentativa de se encontrar algo simbólico nos nossos sonhos";

- "A sensação de calma da atividade";

- "Levo o sonho de uma colega, seus sentimentos e meus sentimentos acerca do sonho dela";

- "Pista de entendimento";

- "Uma experiência única de compartilhamento, uma comunhão de opiniões muito benéfica";

- "Experiência nova, algum conhecimento sobre meus colegas, e perguntas sobre a natureza dos sonhos";

- "As diferenças interessantes entre as formas de representação do sonho através de desenhos e a dificuldade comum em desenhar as emoções";

- "Motivações para explorar outros sonhos, curiosidades quanto aos sonhos e aos próximos encontros";

- "Uma maior atenção ao meu corpo";

- "Um pouco dos meus amigos. Eu conheço boa parte do pessoal que está aqui, algumas amizades mais recentes, algumas mais antigas. Mas eu cada vez mais me surpreendo. Aqui, nós falamos/mostramos facetas de nós que nem nós mesmos conhecemos, acho".

\section{O que deixo aqui...}

- “A minha presença em cada discussão";

- "Uma tentativa de representação de um sonho";

- "Tranquilidade";

- "Uma vivência íntima, mas de certa forma coletiva";

- "Um sentimento do meu sonho que antes só ficava comigo e agora eu posso dividilo";

- "Deixo uma imagem de um sonho e de um sentimento";

- "Meu relato com meu incômodo";

- "Minhas impressões e ideias particulares sobre o mundo dos sonhos e as sensações oníricas";

- "Um desenho bizarro e meus comentários";

- "Meu medo e apreensão, que senti no sonho, ao serem desenhados, tomaram forma e contorno e, de alguma forma, saíram de mim";

- "Reflexões e motivações para outros colegas";

- "O excesso de atenção ao meu racional";

- "Um pouco menos do que, agora, gostaria de ter deixado. Fiquei um pouco insegura, talvez com medo de lembrar um sonho, acabei não desenhando ele. Espero ter a oportunidade mais tarde, agora, com mais coragem". 


\section{ANEXO F: DESENHOS PRODUZIDOS NO $2^{\circ}$ ENCONTRO}

Figura 3: "Ar?"

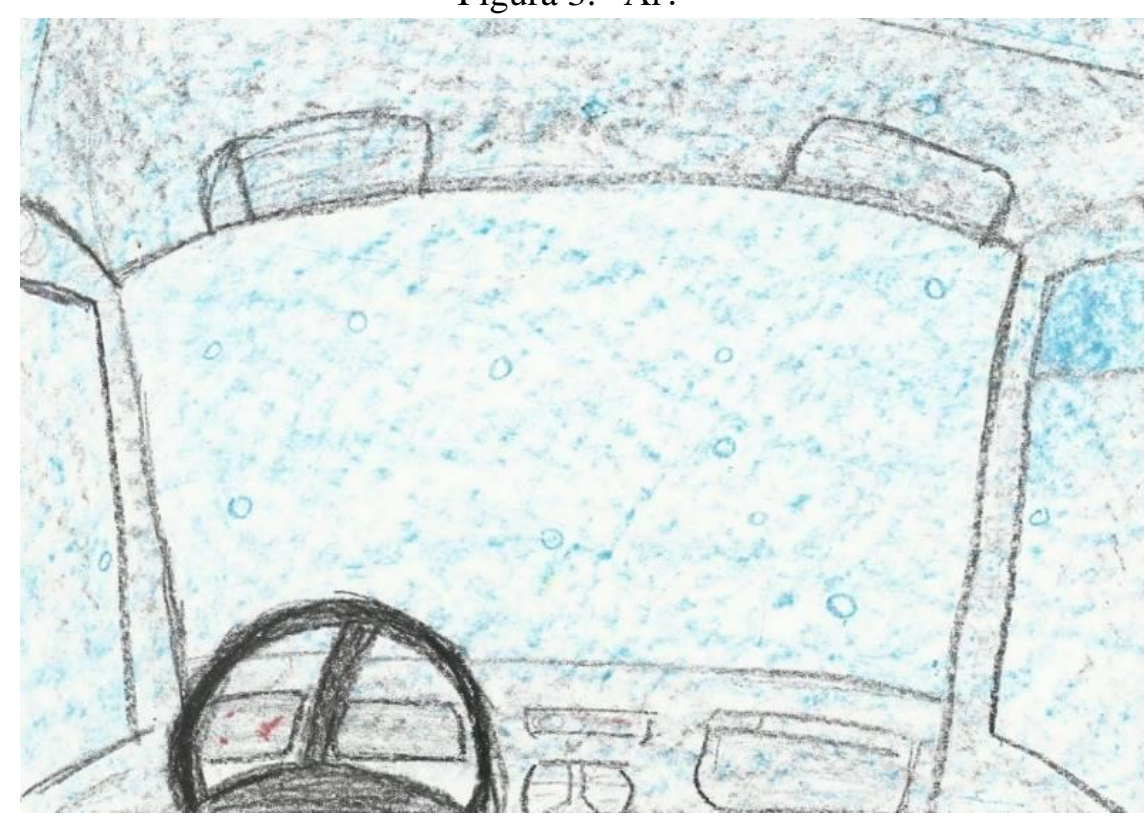

Figura 4: Barco ancorado na Noite

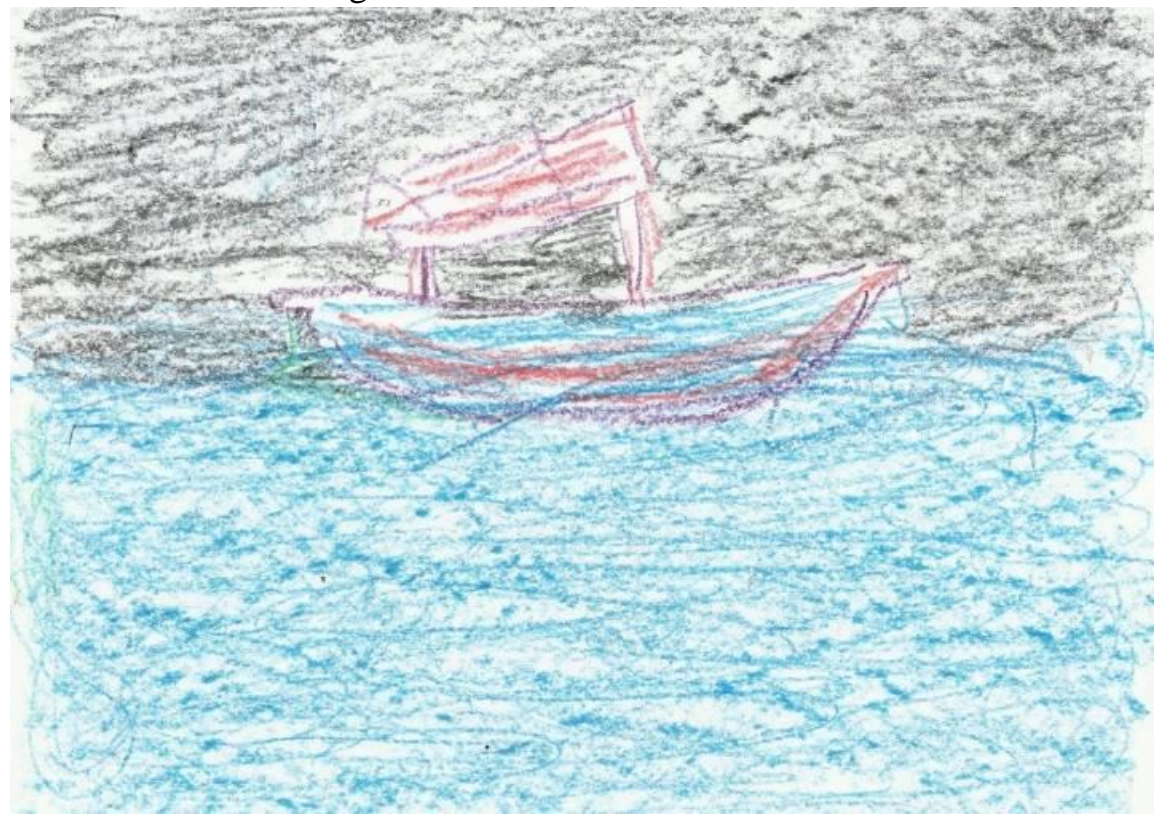


Figura 5: Caixa

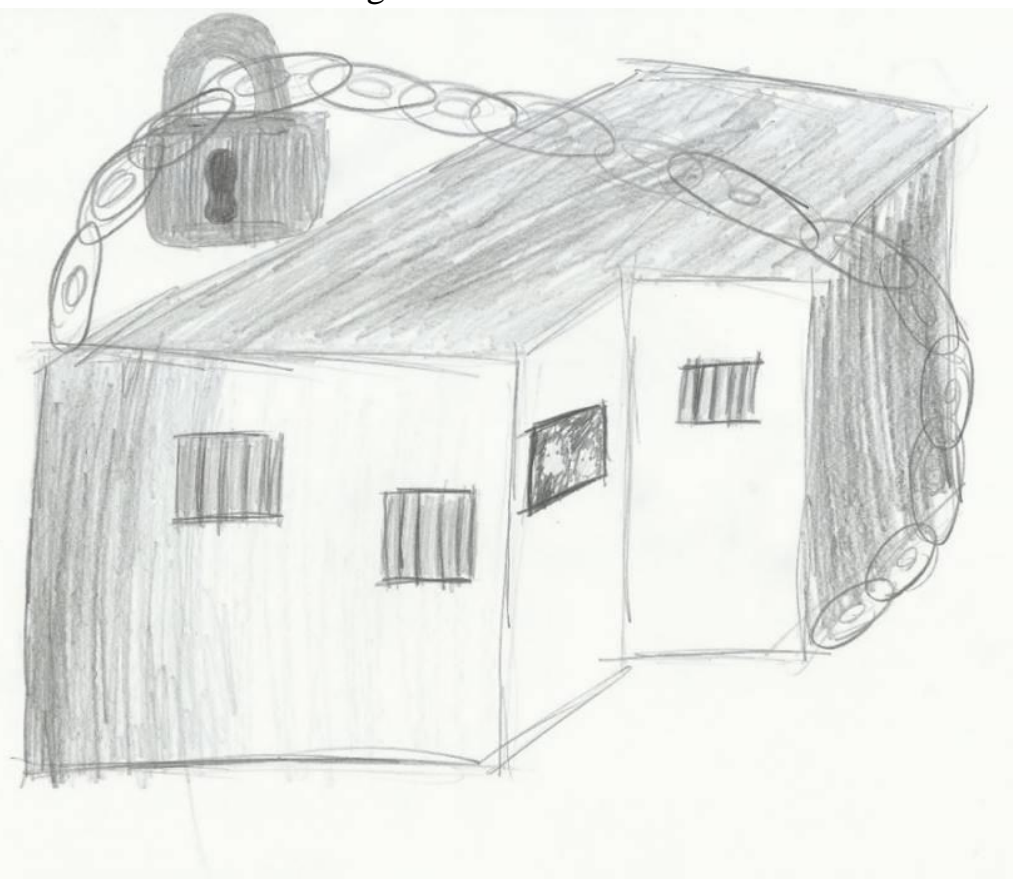

Figura 6: Encontro/despedida

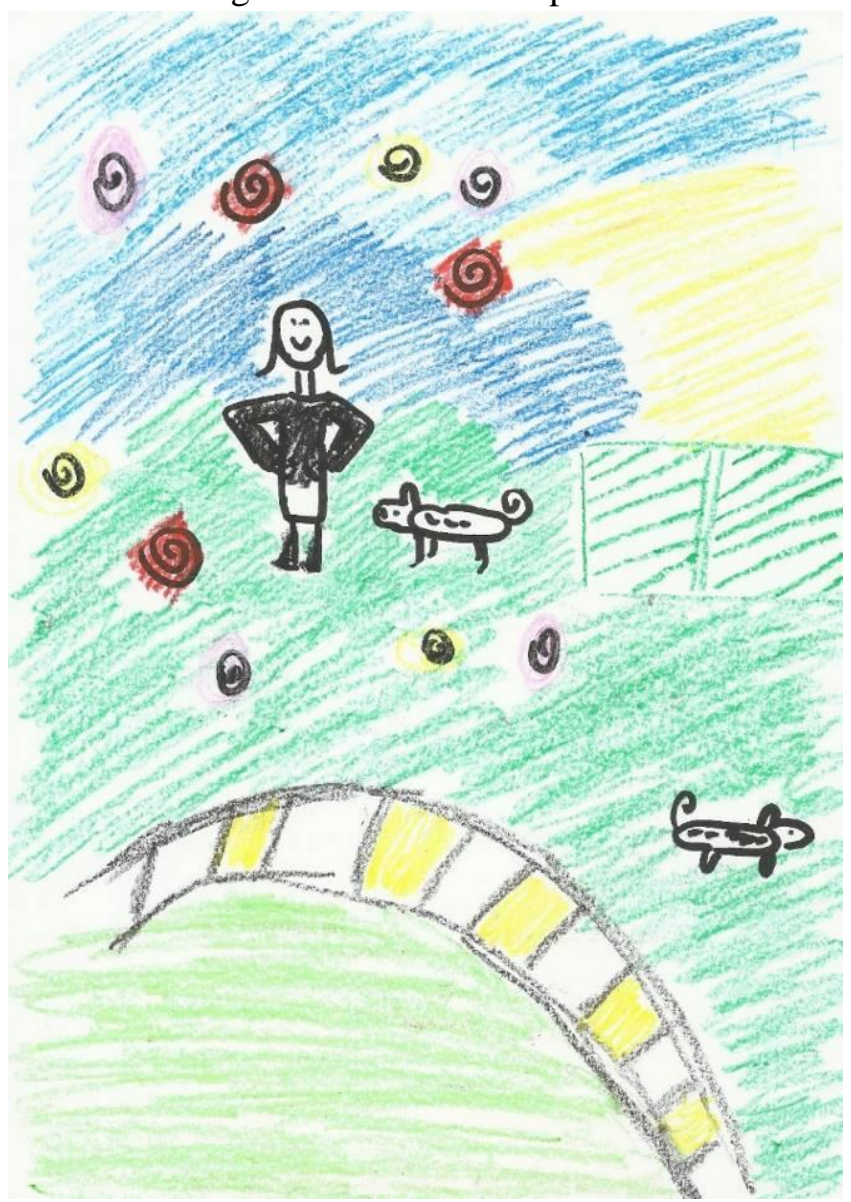


Figura 7: Fogueira de libélulas

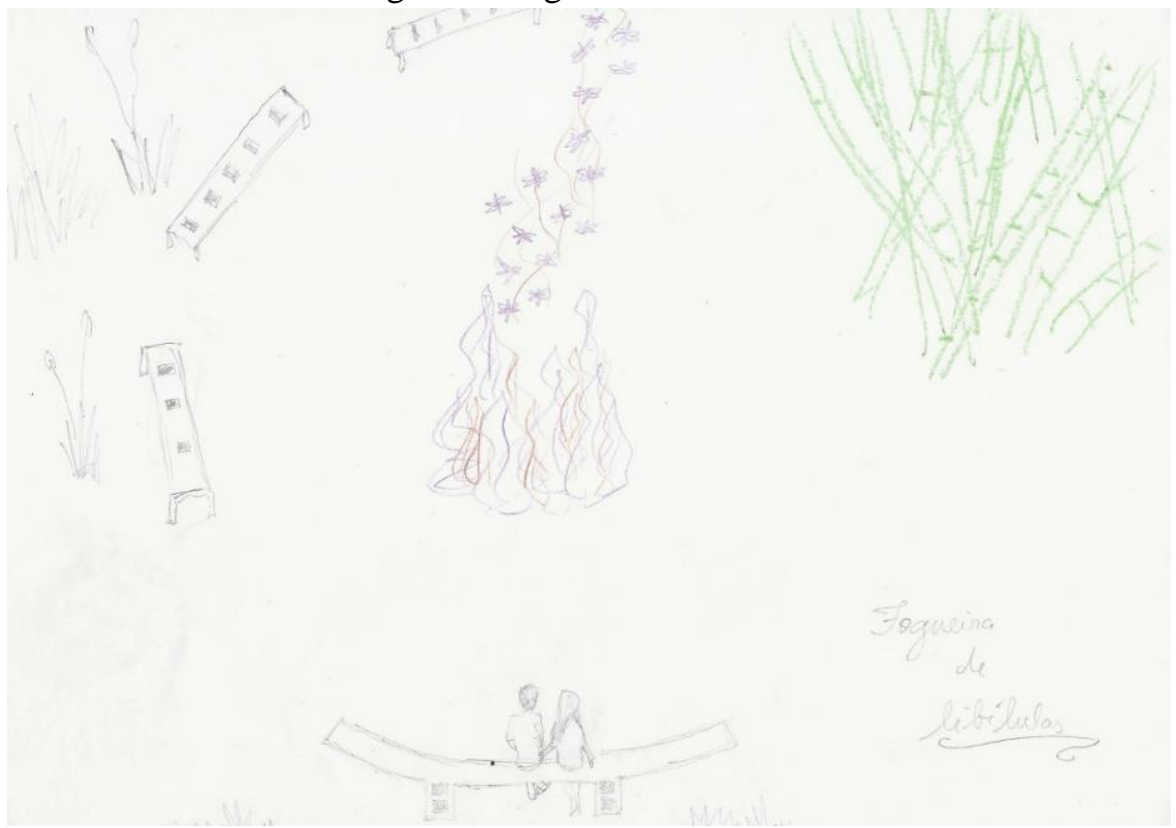

Figura 8: Quente e raiva

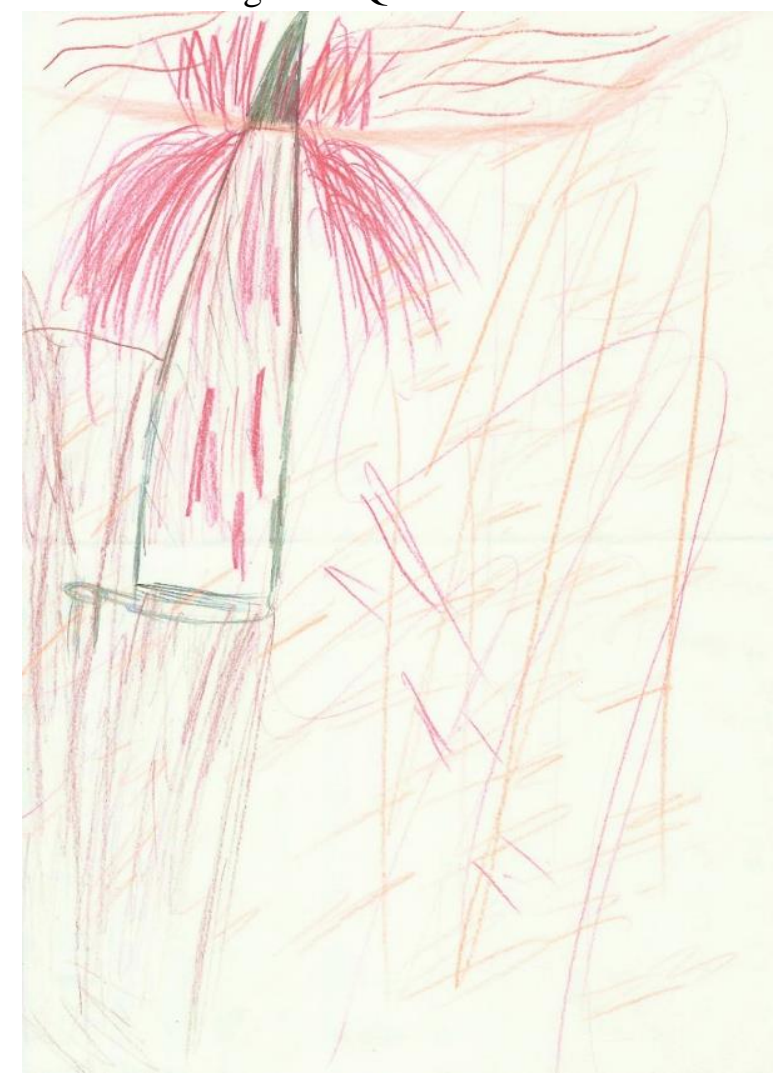


Figura 9: Volta a um passado

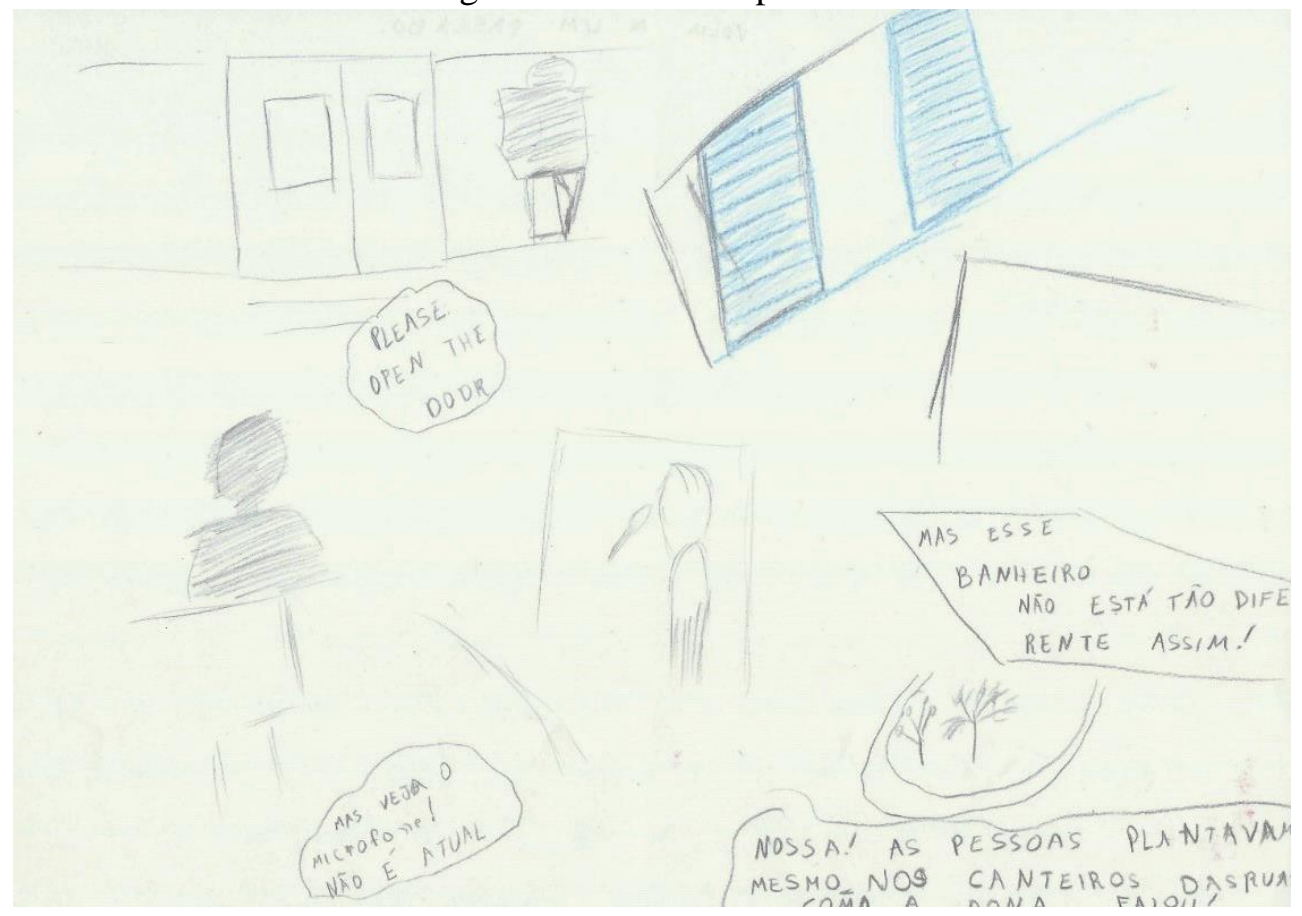

Figura 10: Sopro

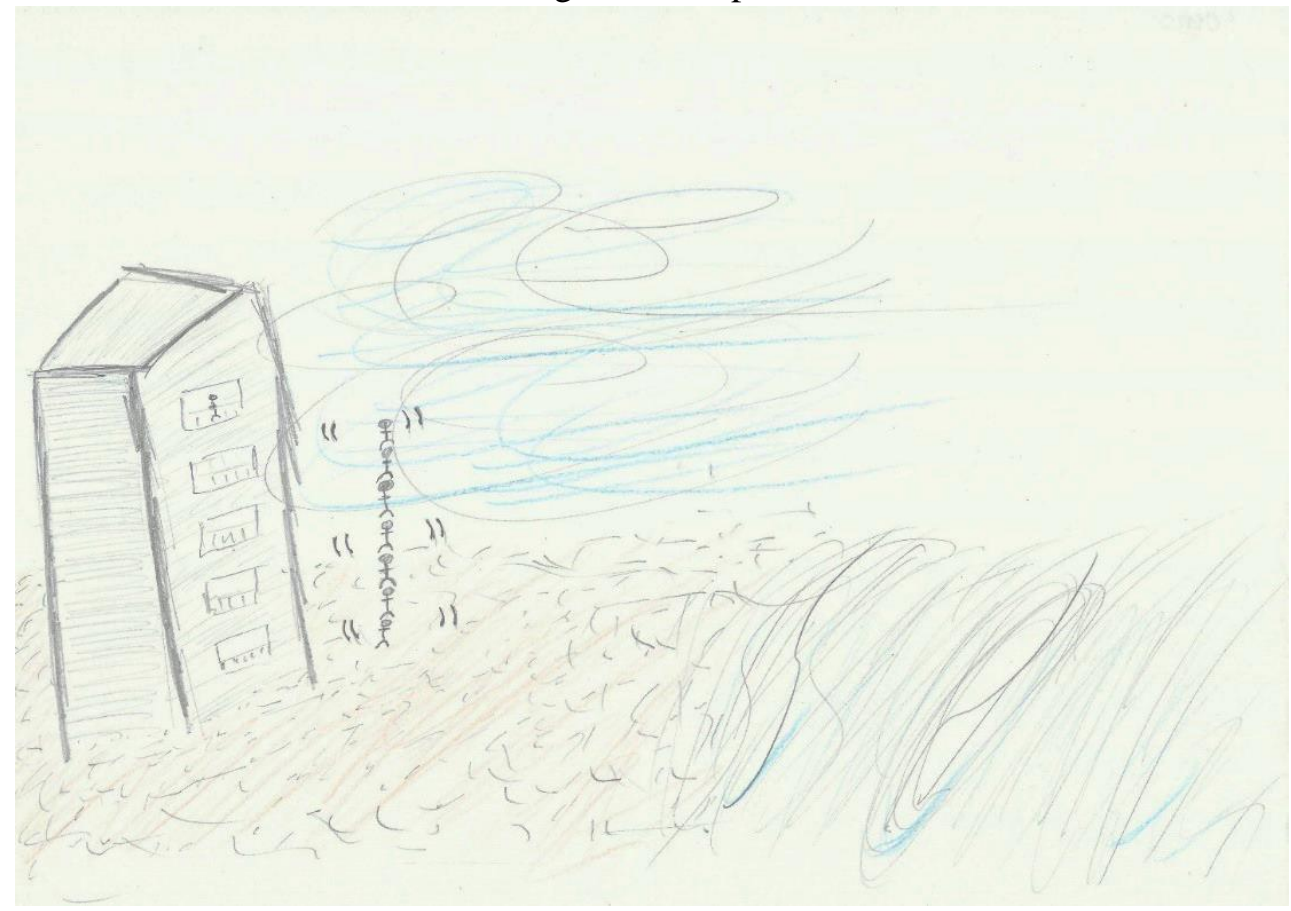


Figura 11: Sem Título

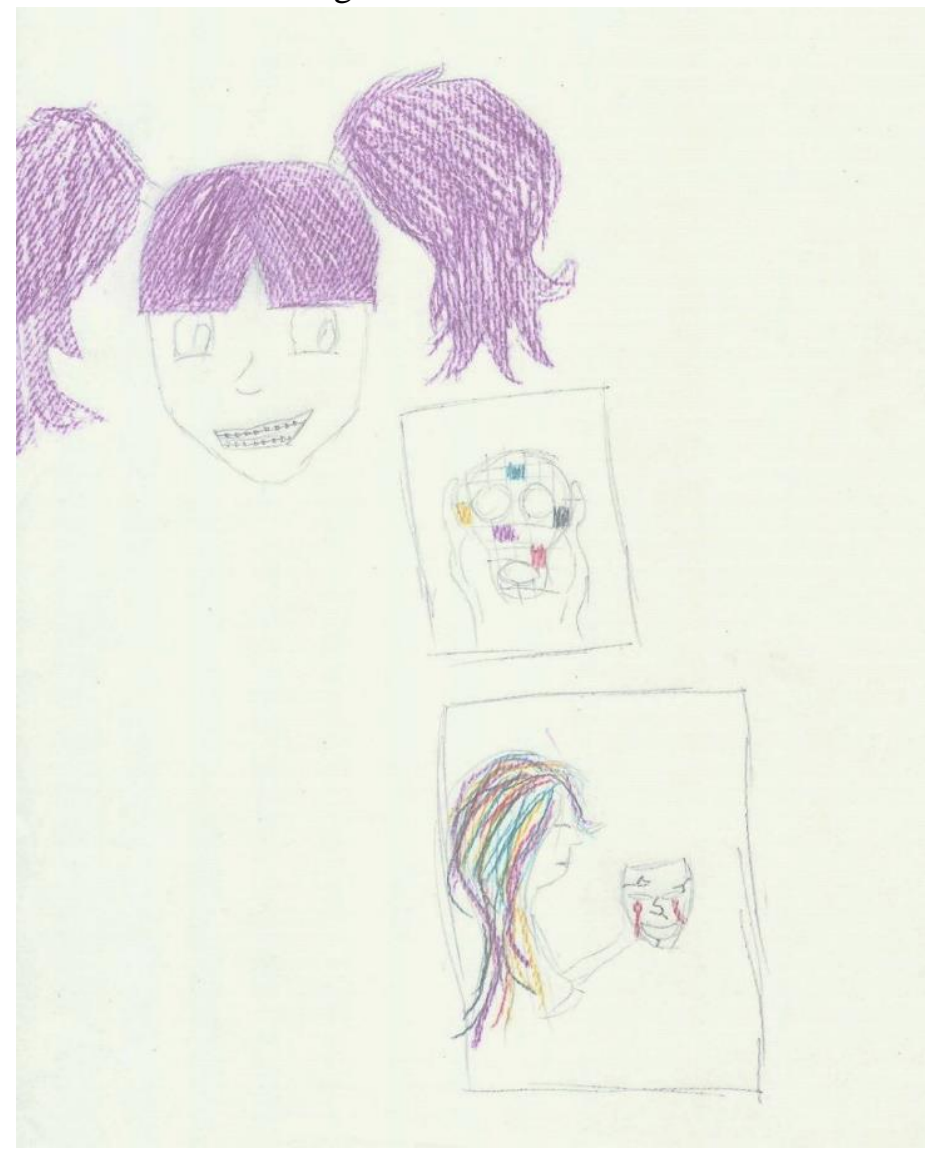

Figura 12: Sem Título

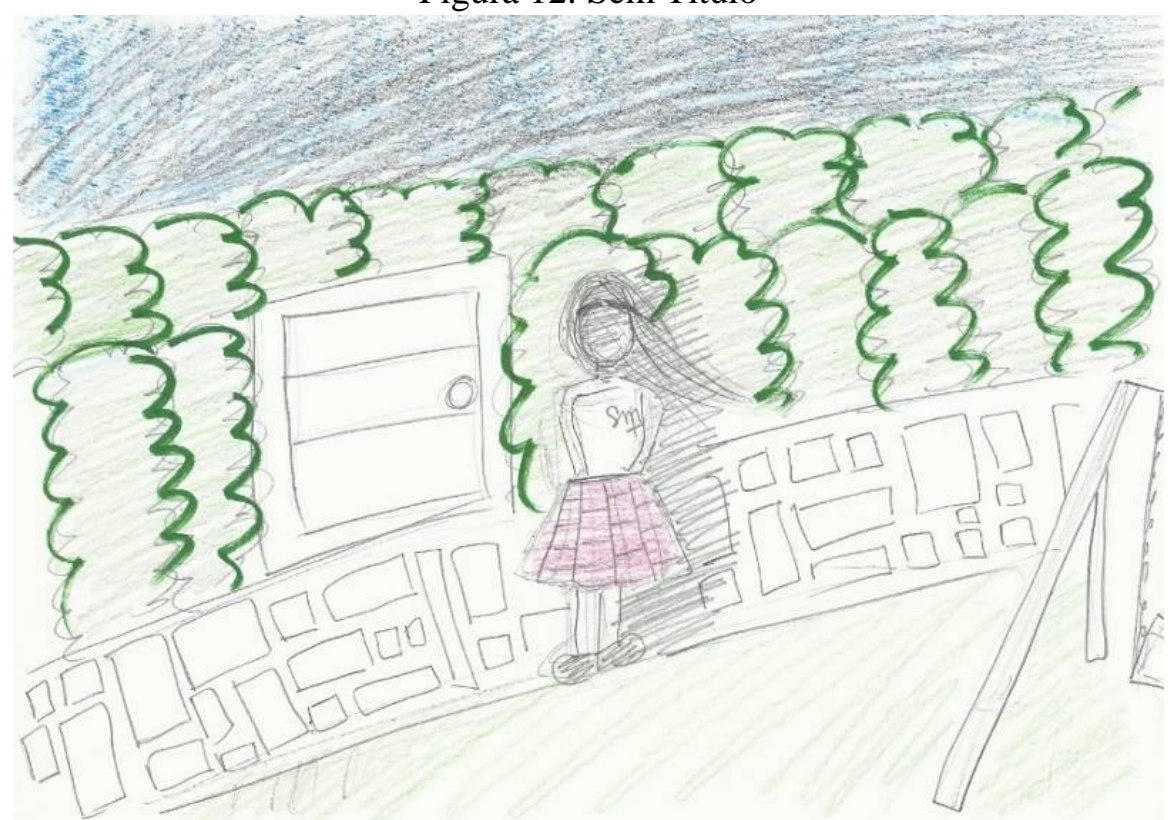


Figura 13: Sem Título

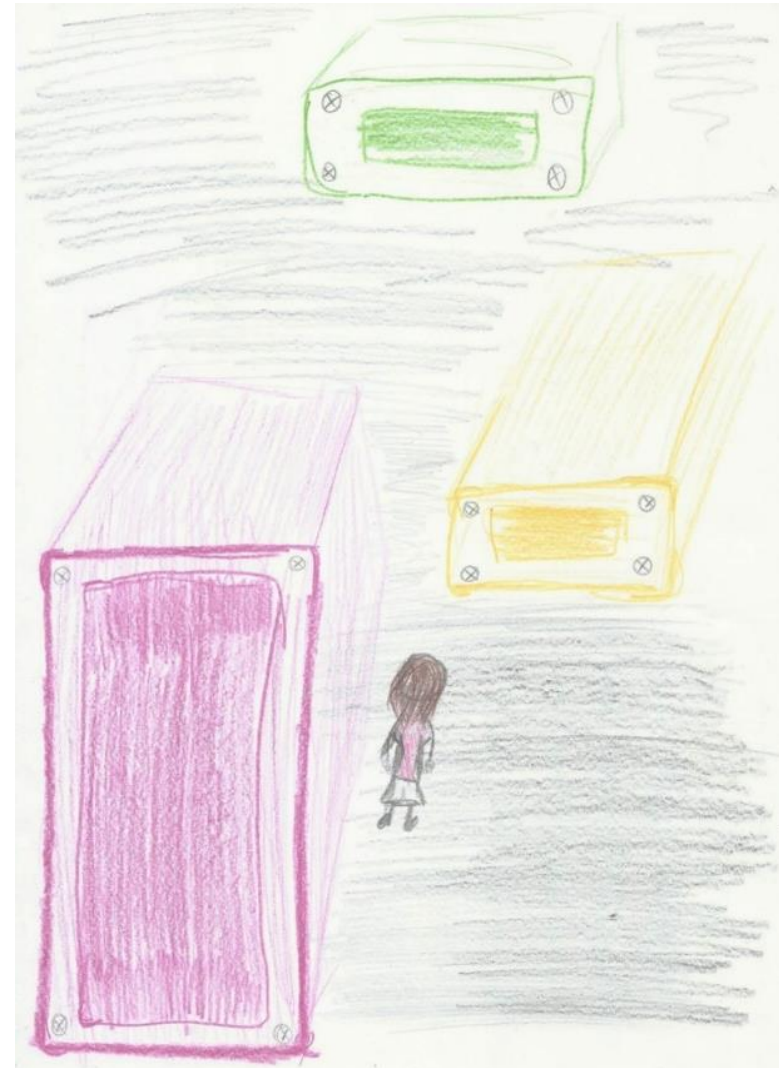

Figura 14: Sem Título

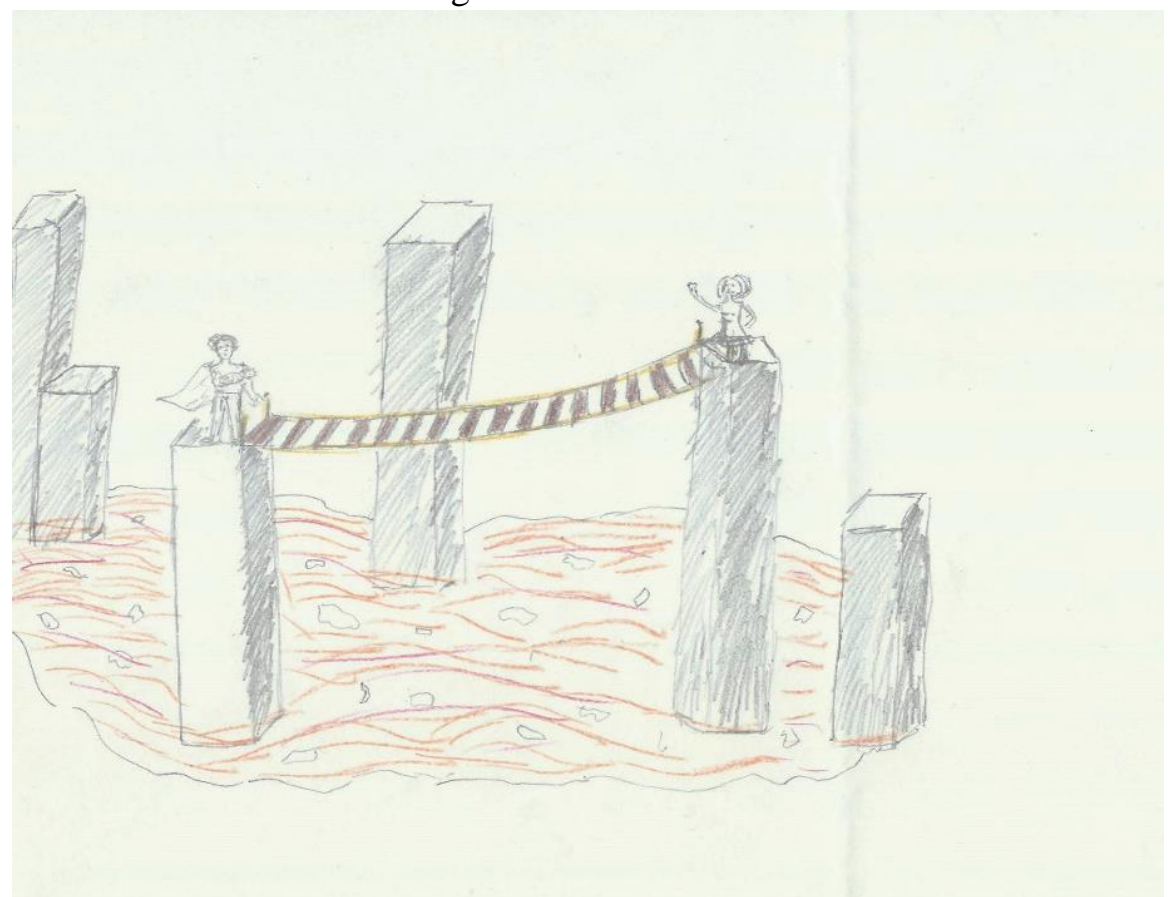




\section{ANEXO G: RESULTADOS DO $3^{\circ}$ ENCONTRO}

Registro do encontro

Este encontro, em três palavras, foi...

- "Intenso, reflexivo, identidade";

- "Sincero, intenso, pessoal";

- "Intenso, impactante e revelador";

- "Legal, descontraído, conhecimento";

- "Alívio, tensão, reflexão";

- "Diversidade, alívio, visceral",

- "Triste, abraço, sorriso";

- "Aliviante, triste e pesado";

- "Diferente, pesado, aliviante";

- "Padecimento, encontro, compadecer";

- "Animado, pesado, divertido";

- "Participante não completou",

- "Forte, emocionante, marcante".

\section{Receber o sonho do meu colega...}

- "Foi uma experiência bastante rica, pois me possibilitou identificar no sonho dele algo meu. Já que ambos possuímos sonhos de infância e recorrentes. Assim, pude ver que não sou a única a ter tido esse tipo de experiência e ela ainda estar tão latente em mim";

- "Um exercício de concentração e escuta atenta do universo que me era apresentado pelo outro. Um novo conhecimento que me exigia responsabilidade pela confiança que ela depositou em mim";

- "Foi acolhedor, percebi que a temática do sonho foi muito parecida com algo que já sonhei e sentia vergonha disso, agora me parece normal";

- "Identificação de sentimento, uma espécie de compartilhamento de um peso e uma certa angústia por carregar esse sentimento que eu também tive no passado";

- "Foi algo que mais nos uniu do que separou, mesmo que o sonho, teoricamente, seja o que temos de mais individual e particular",

- "Foi muito enriquecedor. Não só o que a pessoa narra, mas como narra e os comentários que faz acerca do próprio sonho são de muita importância, e para mim isso ficou nítido. Essa atividade também ajudou a perceber a imensa diversidade de modos de sonhar que temos em nosso grupo";

- "Triste, pois me remeteu a experiências próprias negativas. Mas bom, uma vez que fiquei feliz por vê-lo ter superado";

- "Me deixou com vontade de interpretá-lo e de saber mais sobre a história de vida da pessoa para poder relacioná-la com o sonho";

- "Foi muito interessante, ver os diferentes sonhos que as pessoas têm";

- "Foi bastante intenso e curioso, já que o sonho dele foi bastante profundo e enigmático (e bastante pessoal) ";

- "Foi bom, pois me deu a oportunidade de avaliar um pouco os meus sonhos com outra perspectiva";

- "Intenso, 'pesado', surpreendente"; 
- "Uma experiência interessante, estimulante, curiosa (dupla)",

"Uma experiência intensa, comovente, com a qual eu me identifiquei (grupo)".

\section{Oferecer o meu sonho para o colega/grupo...}

- "Oferecer o meu sonho foi uma experiência bastante aproveitável, pois ao contar o meu sonho parece que revivi de maneira intensa o meu sonho e as sensações que senti. Possibilitou maior significação das imagens do sonho";

- "Foi deixar-me vulnerável";

- "Foi um alívio, falar sobre um sonho que revela grande parte da minha intimidade tirou um pouco o peso dele, mesmo que eu não explicasse o significado de grande parte das simbologias";

- "Expor algo da minha interioridade de forma confortável e harmoniosa";

- "Me senti bem leve. Mesmo revivendo emoções negativas do sonho, contar ele para alguém fez eu me sentir bem”;

- "A recepção que obtive foi ótima, e senti que meu sonho contribuiu de verdade para a imagem em construção que essa pessoa (Beth, que fez dupla comigo) faz de mim. Foi prazeroso e interessante compartilhar minhas impressões sobre meu próprio sonho e ouvir os comentários dela";

- "Foi engraçado e curioso, sentimentos a que este sonho me remete";

- "Foi muito bom. Meu sonho era um tanto pesado e estava me incomodando: compartilhá-lo fez-me sentir mais leve”;

- "Foi diferente, eu nunca tinha contado um sonho que tinha me marcado de uma forma tão negativa em detalhes para alguém e foi muito bom poder falar",

- "Me trouxe alívio, pois me identifiquei com ele ao contar meu sonho, que pensei que seria julgado por. Além disso, intensificou minha crença de que todos são únicos, interessantes, e principalmente esquisitos",

- "Foi uma troca interessante. Fez que eu me percebesse que há mais de um "modo" de ser sujeito de um sonho, o que é interessante";

- "Tranquilo, gostoso, elucidativo";

- "Um pouco difícil, complexa, mas também divertido. Foi interessante a análise que a colega fez do meu sonho".

\section{O que levo daqui...}

- "Levo daqui um sentimento de compreensão mútua, que senti no grupo após a troca de sonhos",

- "Compreensão dos colegas";

- "Leveza”;

- "Conhecimento e identidade",

- "Material para refletir por um bom tempo. Espero não esquecer ou tentar fingir que não aconteceu”;

- "Ainda mais interesse em conversas sobre sonhos, elementos oníricos, psicologia junguiana...";

- "A sensação de que nossos sonhos dizem coisas ou trazem situações que devem vir à tona pois não viriam de outra forma, para limpar um sentimento consciente ou não";

- "A diversidade entre os sonhos de diferentes pessoas, tanto em forma quanto em conteúdo”; 
- “As possibilidades que o sonho traz (de ser um alívio, um alarme...) ",

- "Identificação, compadecimento e um sonho profundo para refletir sobre":

- "Uma visão diferente daquela com a qual entrei";

- "Reflexões, dificuldades próprias...";

- "Um sonho de uma colega sobre o qual refletir".

\section{O que deixo aqui...}

- "Deixo aqui um pouco de como eu enxergo os meus símbolos ao contar para minha colega";

- "Um pedaço da minha história";

- "Parte da minha timidez";

- "Um pouco da minha personalidade";

- "Deixo uns pedaços da minha história que eu já acreditava ter esquecido, ou tinha preferido ignorar. Lembrar deles, por meio do sonho do Pedro, foi algo bom”,

- "Entusiasmo para o próximo encontro! ";

- "Minha curiosidade sobre o funcionamento da cabeça das pessoas":

- "Meu sonho e seu relacionamento com minha vida pessoal talvez tenha ajudado meus colegas a entendê-lo melhor";

- "O meu sonho e o sentimento que ele me trouxe";

- "Identificação (espero) e um sonho curioso para reflexão";

- "Uma reflexão sobre os diferentes tipos de sonho";

- “Opiniões, sentimentos...";

- "Um sonho que significa algo para mim”. 


\section{ANEXO H: RESULTADOS DO $4^{\circ}$ ENCONTRO}

Registro do encontro

Este encontro, em três palavras, foi...

- "Emocionante, divertido, solto";

- "Divertido, engraçado, nostálgico";

- "Bagunçado, divertido, inspirador";

- "Profundo, elementos, dinâmica";

- "Divertido, interessante, desenvolvedor";

- "Criatividade, leveza, (ex)pressão";

- "Terra, totem, divertido";

- "Divertido, bagunçado, inovador";

- "Diferente, concreto, desafiante";

- "Divertido, leve, desafiador";

- "Sensorial, pessoal e reflexivo";

- "Ouvir, pensar e criar".

\section{Ouvir o sonho do meu colega...}

- "Foi curioso e divertido";

- "Interessante",

- "Foi inspirador";

- "Foi muito rico e instigante, como fora no último encontro";

- "Foi legal, pude identificar certa identidade com o sonho da colega";

- "Foi curioso. Eu conseguia (ou projetava?) sentir questões que eu antes via como particulares minhas no sonho da minha colega, foi ótimo";

- "Foi bastante divertido e interessante, principalmente porque uma cena "boba" acabou sendo muito marcante";

- "Foi angustiante";

- "Foi interessante e ao mesmo tempo curioso";

- "Foi muito legal, até porque ele já tinha sonhado com a pessoa do sonho de hoje e foi legal ver como os dois sonhos se relacionam";

- "Foi curioso, prestei atenção em algo que geralmente passaria despercebido, a linguagem verbal me disse muito";

- "Um convite à criatividade".

\section{Modelar um aspecto do sonho do meu colega...}

- "Foi interessante de ver o resultado, gostoso pelo processo, mas ligeiramente frustrante pois não consegui fugir da representação óbvia”;

- "Inusitado, permitiu a exploração";

- "Engraçado, sério, um desafio, recompensador"; 
- "Foi desafiador. Uma experiência nova, em que não há sentido em falar em erros, pois tudo é mutável em argila. Pensei apenas no cenário-base da minha representação, o restante foi surgindo ao longo da modelagem";

- "Desafiador e acho que não consegui representar completamente o sonho na argila, mesmo tendo gostado da atividade",

- "Me mostrou uma possibilidade totalmente diferente de expressão. Não sendo uma área que eu domino, eu me senti mais leve para criar, menos presa a técnicas";

- "Foi muito divertido, apesar da modelagem final ter deixado a desejar (mas foi representativo!)";

- "Foi divertido e diferente";

- "Foi algo bem diferente e me possibilitou concretizar por meio da argila, uma cena que me marcou no sonho";

- "Foi um desafio. Dar o contorno tridimensional ao sonho não foi fácil";

- "Foi difícil, como uma palavra que expressa um sentimento para mim foi o mais marcante, pensei em modelar a imagem central do sonho, que na verdade não foi relatada, apenas pressuposto".

- (Não há resposta).

\section{Ver um aspecto do meu sonho modelado...}

- "Foi interessante e gostoso";

- "Engraçado, diferente do que tinha pensado";

- "Muito engraçado”,

- "Libertou um pouco o sonho do seu aspecto angustiante e aflitivo. Ajudou a despessoalizar ou a tornar mais universal outra parte do sonho, o que no caso específico foi muito interessante; seria uma forma talvez possível de se lidar com os medos que esse sonho revela";

- "É como ver o sonho de outra forma (concreto), diferentemente da confusão de imagens do sonho";

- "Foi, literalmente, uma coisa completamente nova. Foi como ver uma interpretação concreta da minha interpretação verbal (porque, afinal, contar o sonho para alguém, escolher palavras e dar corpo a elas, já é interpretar) ";

- "Foi bastante lisonjeador (tanto pela facção, quanto pela qualidade) e também bom para ver qual cena seria a mais marcante";

- "É um novo modo de ver aspectos diferentes do meu sonho";

- "Foi um desafio, pois não consegui entender direito o que o modelador do meu sonho pensou ao construir a cena";

- "Foi legal, vê-lo em 3D me ajudou a pensar no meu sonho por uma outra perspectiva";

- "Foi confuso, acho que faltou abertura da minha parte a explicar melhor o que o sonho significava, para que ele pudesse representar melhor, mas foi um sonho muito intimo e não quis me expor".

\section{O que levo daqui...}

- "Um sorriso pelo prazer da troca";

- "Diversão";

- "Um sonho/ uma ideia que faz refletir"; 
- "Uma conexão firmada com essa atmosfera de sonhos, cada vez mais forte, mais consolidada. A associação entre os sonhos, todos nós que participamos do grupo e o próprio ateliê já me parece ser perene";

- "Aprendizado";

- "Possibilidades de expressão novas, espero não esquecê-las tão logo! ";

- "Um elogio, um sorriso e argila nos dedos";

- "Argila; uma nova perspectiva sobre meu sonho";

- "Uma experiência bem diferente";

- "Uma outra forma de ver meu sonho";

- "Meus pensamentos".

- (Não há resposta).

\section{O que deixo aqui...}

- "Uma curiosidade para alguém”;

- "Diversão";

- "Um pouco da minha própria reflexão";

- "Meu envolvimento sincero com as atividades e com as ideias que aqui surgiram";

- "Contribuição para o entendimento do sonho";

- "Bastante coisa. Me sinto (positivamente) descarregada! ”;

- "Uma péssima escultura, um totem extra e, com sorte, um pouco de humor";

- "Uma visão superficial sobre meu sonho";

- "Uma tentativa de expressar sentimentos e sensações de outra pessoa";

- "Uma contribuição para o sonho do meu colega";

- "Minha incapacidade de encarar algo".

- (Não há resposta). 


\section{ANEXO I: MODELAGENS E SEUS RESPECTIVOS SONHOS}

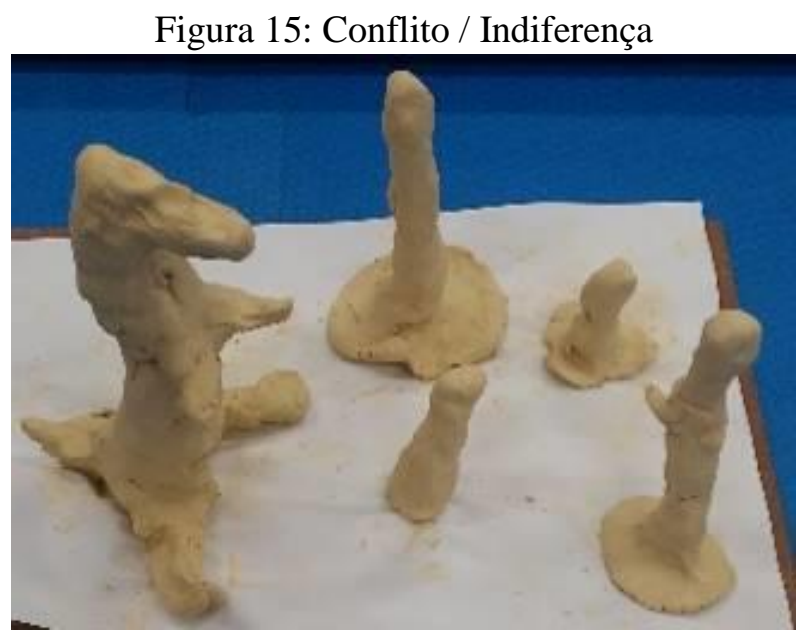

"Esse sonho eu tive hoje de manhã e fala da... deixa eu começar do começo, eu tinha um conflito com meu irmão e parecia que era o irmão mais velho... em seguida, eu fui perseguida por lobos ou por pessoas, era mais pessoas, mas pareciam lobos, não tinha uma visão assim perfeita do que era mesmo, como se fosse uma aceitação e eu correndo pra minha mãe e ela faz de conta que não era com ela, não deu atenção e o lugar que eu corria em direção a ela era um lugar próximo da minha casa também e é isso assim”.

Figura 16: Up’n’́down / Escolhas e observações

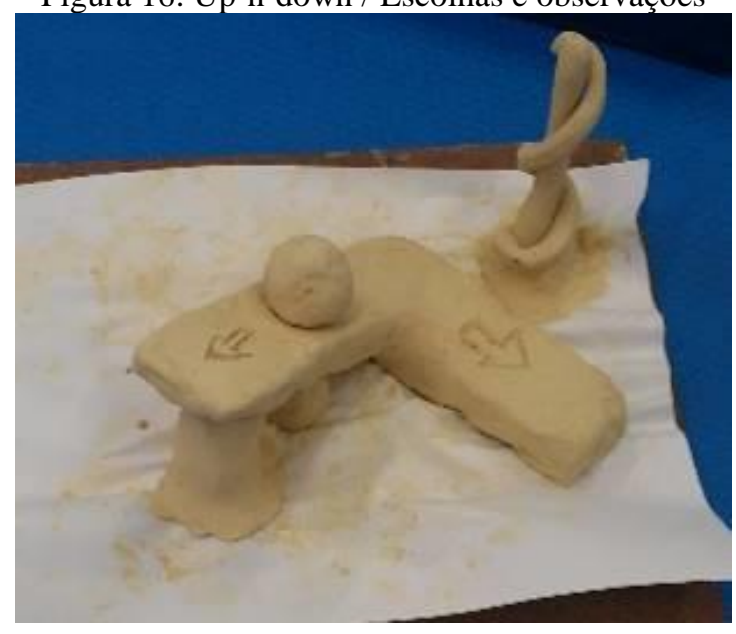

"A gente estava numa sala, a gente estava tendo aula com a professora, só que tipo não tinha nenhum de vocês, era um pessoal x que eu nunca tinha visto e aí numa sala que eu também nunca tinha visto e aí eu saía para pegar água, mas era uma água com cloro, da cor dessa água com argila e eu levei a água e falei não, não vou ..., e no que eu estava voltando pra sala eu vi entrando no elevador um professor meu do cursinho e ele parou para conversar comigo e ficou segurando a porta do elevador e aí a mulher que estava no elevador começou a olhar feio pra ele e ele "ah desculpa, me acompanhe", e ai a gente foi conversando até a escada ai eu acordei. Foi isso". 
Figura 17: Brincadeira de criança / Dia de Festa

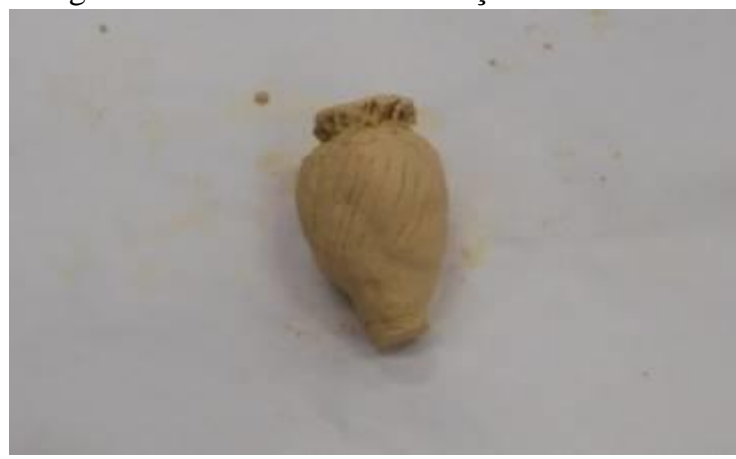

"Meu sonho foi realmente bem curto. Essa semana que eu estive em casa, foi aniversário do meu irmão e eu tinha sonhado que na minha casa tinha tido uma festa, era uma festa de aniversário, só que a festa não foi para ele, foi pra mim, eu acho que não precisei muito mais que isso pra entender o que ele estava querendo me dizer, foi bem rápido mesmo o sonho, as pessoas chegando, me dando presentes, dando parabéns pra mim e eu acho que ele não estava nem no sonho".

Figura 18: Possibilidades / Ciclo no chão, marcha em ascenção

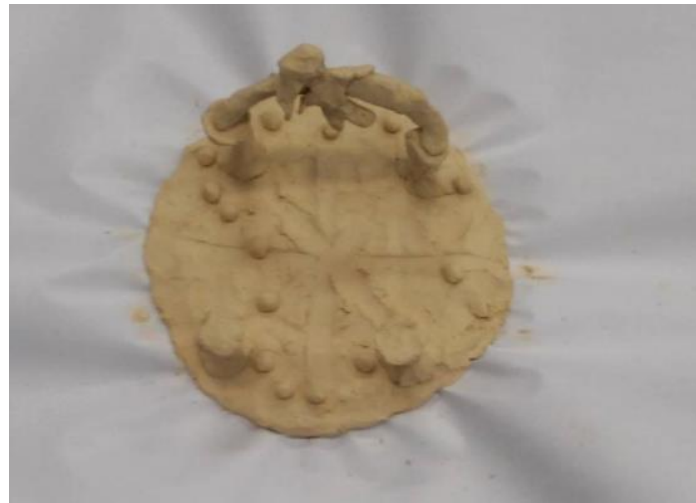

"Foi um sonho que eu tive, não sei se foi hoje ou se foi ontem ou se foi... foi assim, eu não lembro de como começou, mas eu lembro que eu estava no térreo do meu prédio, que ele não é grande, mas uma coisa que sempre me chamou atenção ele é meio redondo, você consegue dar volta nele infinitamente e era meio isso que eu estava no meu sonho, eu estava dando voltas, acho que eu estava procurando alguma coisa, mas não sabia bem o quê, e eu estava com uma sensação de responsabilidade muito grande porque tinha alguma coisa que eu tinha que procurar que eu tinha que encontrar, aí a parte surreal do meu sonho é que tinha uma menina, uma criança, que eu não faço a mais remota ideia de quem seja, nenhuma prima, não dá nem pra ver o rosto direito, mas ela está escalando, sabe tela de proteção? Tinha uma não sei como, porque não estava sustentando absolutamente nada, mas ela estava escalando e eu nossa, isso vai rasgar e aí, eu acho que é tudo o mesmo sonho. Só que não ia meio que pra lugar nenhum, ela estava lá e tinha uma criança escalando e mano, uma coisa que eu acordei, que eu não estava brincando quando eu falei que fiquei muito chocada com Game of Thrones ${ }^{14}$ e que eu vou parar de assistir por um tempo porque sabe quando o Drogo morre, que colocam um

\footnotetext{
${ }^{14}$ Game of Thrones é um seriado norte-americano escrito por George R.R. Martin.
} 
travesseiro nele? Eu sonhei que eu tinha que fazer isso por alguma razão, tinha alguma coisa que eu só ia conseguir se eu fizesse isso, mas no fim eu acabei que não fazendo, eu acordei. Acho que era essa a pendência, não sei, foi um sonho muito louco. Era tudo ao mesmo tempo".

Figura 19: A chama apagada / Angústia

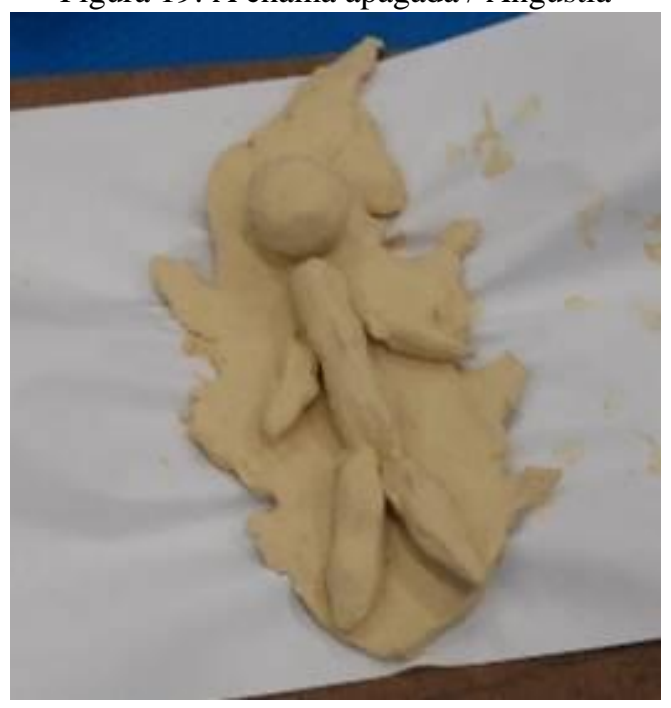

"O sonho que eu tive foi um sonho muito tenso que era assim, eu saía de manhã e ia andar com meu cachorro e ficava o dia inteiro fora, a gente ia andar por uns morros, não sei, algum lugar assim e quando eu voltava no fim da tarde, eu estava voltando pra casa, nem sei como era minha casa, não era minha casa do jeito que ela é, mas aí tinha muita fumaça, dava pra ver que tinha fogo em algum lugar, só que nessa hora deu uma sensação muito ruim, que tinha alguém

lá dentro e de que era alguém de casa e aí eu sei que não tive coragem de ver, fiquei numa colina, num morro de longe, vendo e aí uma hora tudo sumiu e aí eu tinha certeza que tinha acontecido alguma coisa com minha mãe, mas eu não tinha coragem de ver porque eu meio que sentia e uma hora meu cachorro foi lá e depois ele voltou e aí eu não sei, meio que ele trouxe uma mensagem, mas ele não falou nada, mas eu tinha certeza que tinha acontecido alguma coisa assim horrível. Daí no sonho tinha acontecido mesmo o incêndio e a minha mãe tinha morrido só que aí eu não tive coragem de ir lá ver e no dia seguinte teve um velório, foi alguma cerimônia, minha mãe sempre falou que ela queria ser cremada, mas foi tudo ao contrário, porque como já tinha acontecido o incêndio, a cerimônia foi na beira de um rio, que é o rio que passa na minha cidade, mas eu não vi, eu não fui. Uma hora deu aquele arrependimento de não ter ido, não foi um arrependimento, eu não sei, como eu não tinha ido, eu não encontrei ninguém eu não sabia onde era, eu não sabia o que estava acontecendo e aí quando eu cheguei lá não tinha mais ninguém e aí eu só consegui, só tinha alguém lá, tipo um zelador, não sei, mas tinha tipo um templo na beira do rio e ele só falou que eles tinham colocado numa canoa e tinha soltado o corpo pro rio, mas daí passou muito rápido. A maior parte do sonho, a parte

que eu achei mais extensa, eu ia com meu cachorro pela beira do rio e eu quase sempre chegava perto dessa canoa, mas não conseguia ver se era minha mãe mesmo que estava lá ou como que era, as vezes conseguia ver só um pedacinho, mas e quando eu chegava, vinha uma árvore na frente e eu não conseguia ver mais ou então chegava uma hora que o rio tinha uma ponte que eu tinha que atravessar a ponte para ir para o outro lado e continuar andando pelo outro lado, mas na hora que passava a ponte, a hora que ela passava por baixo da ponte ela não voltava mais e era essa angústia enfim, uma hora ia chegar no mar, mas nunca chegou e aí acabou assim. Mas foi meio poético, as paisagens, foi isso”. 
Figura 20: Desespero / Desespero Líquido

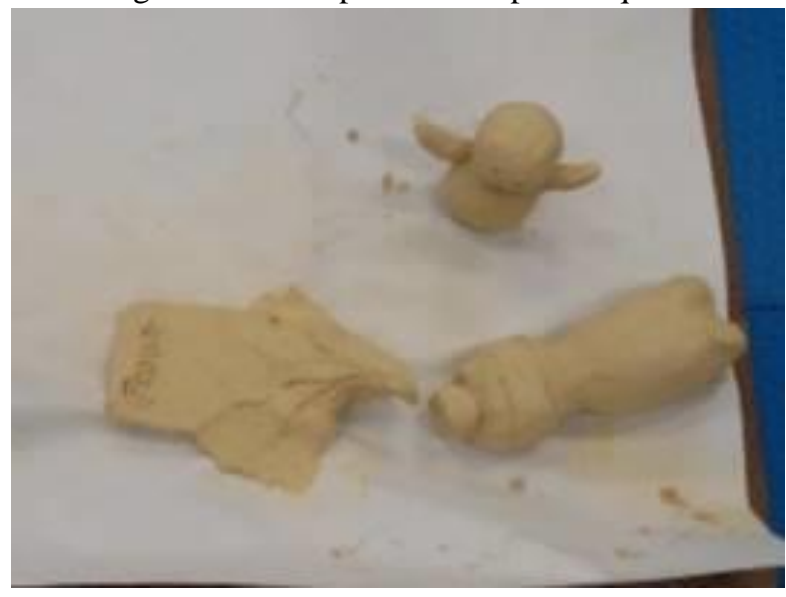

"Meu sonho é assim, já faz um tempo, foi acho que entre a semana de recepção e a matrícula, no carnaval. E aí eu estava, eu sonhei que eu estava num lugar que era um prédio de universidade e aí eu ia fazer o vestibular de novo. Que pesadelo! E aí eu ia fazer o vestibular só que o vestibular na verdade, ela não, não era bem o vestibular era tipo, era o vestibular mas era tipo uma outra prova, era quarta fase, não, era a terceira fase e eu não sabia o que fazer, aí eu começava a fazer a prova e eu não sabia nada e eu entrei num desespero assim e na verdade antes de eu fazer a prova. Espera, confundi tudo. Eu estava no lugar, só que na hora que eu fui procurar a sala da prova eu não achava e aí eu começava a encontrar várias pessoas da minha sala do meu colégio, professores e eu falava pra eles: aonde é a sala que eu vou fazer o vestibular, onde é a sala? E eles me ensinavam só que eles me ensinavam errado e aí eu ia para os lugares e aí eu chegava e falava, não, não é aqui. Aí eu saía correndo e isso faltava 5 minutos pra acabar o tempo e aí era um lugar gigantesco, tipo uma universidade mesmo e eu saía para todas as salas e eu não achava o lugar que era pra fazer prova, até que deu 1 hora e eu achei o lugar e comecei fazer prova. Só que na hora que eu comecei fazer prova caiu algum negócio na minha prova, caiu um líquido e aí rasgou a prova inteira e aí eu saí correndo atrás de uma mulher pra ela trocar minha prova e ela falou que não ia trocar e aí eu não consegui fazer a prova. E eu acordei. Foi horrivel”.

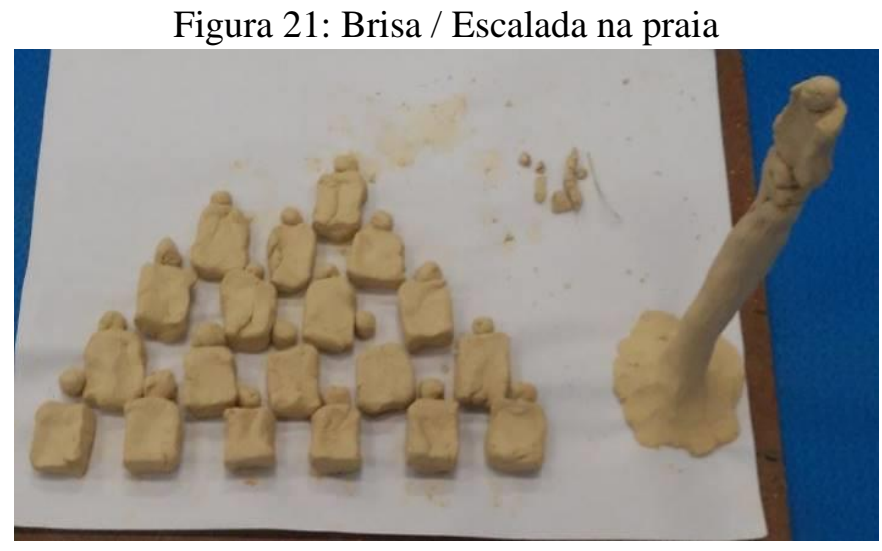

"Bom, os três sonhos que eu tive semana passada que eu lembro mais eu acho que eu não quero compartilhar agora, então vou usar o que usei semana passada, que é bem bobo. Eu estava na praia e tinha um prédio na areia mesmo e aí eu estava numa varanda desse prédio e quando eu olhei para baixo estava formando... uma pessoa estava subindo no ombro da outra, uma torre de pessoas, aí eu achei legal e tal e aí eu peguei, da varanda eu saí e entrei na torre, 
só que aí eu vi que estava, eu achei meio perigoso e aí eu voltei para a varanda. Só que quando eu voltei para a varanda, era a varanda do andar de cima, eu tinha subido de alguma forma, $e$ nisso que eu voltei pra varanda do outro andar, eu vi que bateu um vento e a torre começou a balançar e todo mundo caiu. Foi isso, dai eu acordei achando engraçado, não foi um sonho ruim"

Figura 22: "Impedimento"/ Não fale. Não se pode falar

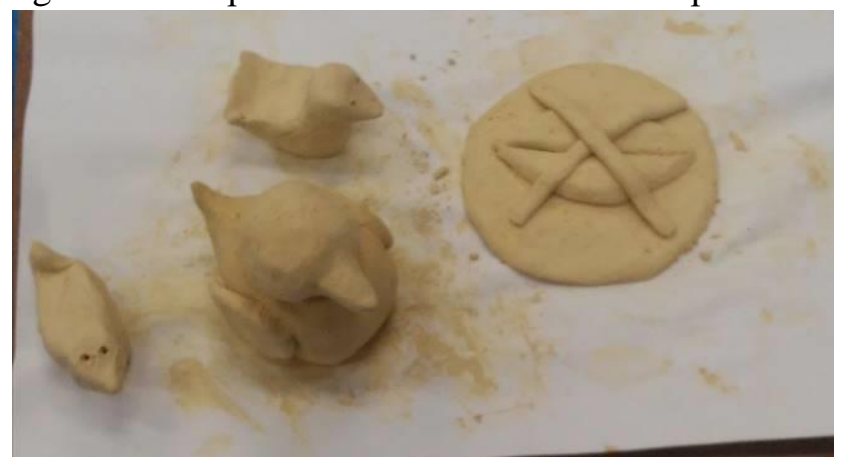

Observação: Os três patos não integram a modelagem do sonho.

"Eu tive um sonho que era, foi essa semana, que era, eu pensei em falar outro sonho, mas fechei o olho agora e eu lembrei que eu tive um sonho com a pessoa com quem eu sonhei no sonho que eu compartilhei e aí eu vou falar esse. A gente estava, tinha a família dela, umas pessoas que eram da família dela e não são na verdade, são outras pessoas, mas era como se fosse. E tinha um problema, eu não podia conversar com ela por alguma coisa, tinha tipo alguma coisa acontecendo entre nós. Ela não queria falar comigo, era isso, mas eu estava falando com a família dela e a gente estava num lugar fora da cidade e ela estava sarcástica, cínica, desdenhosa, desinteressada na minha presença, ela estava ativa, ela estava assim interessada em outras coisas, ela estava com a cabeça em outros lugares, estava com um olhar muito malicioso, um sorriso de segundas intenções, parecia e eu próximo a ela, sei lá o que eu estava fazendo, eu não lembro, mas tinha a família dela, eu falando com a família dela um pouco, e ela e a gente não falava".

Figura 23: Cabelo e espada / ALT: Sandá Descabelado

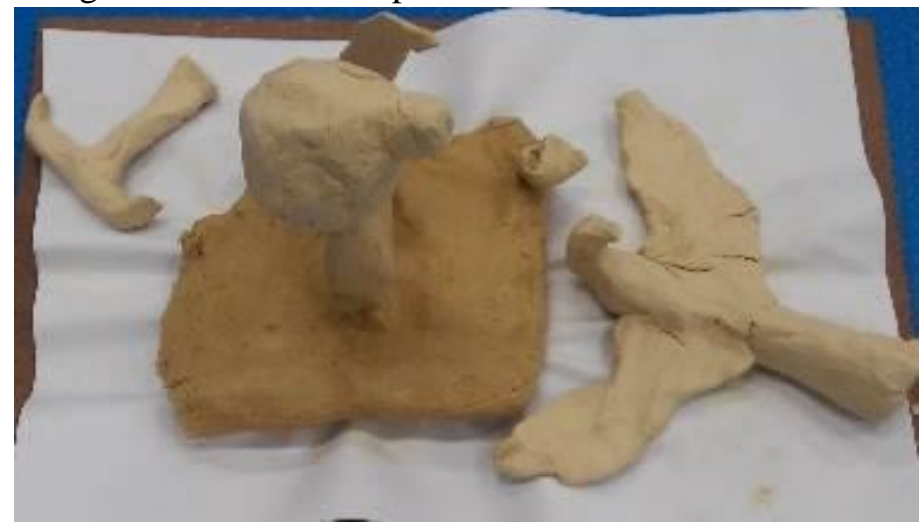

Observação: o pássaro e a ferramenta não fazem parte da modelagem do relato do sonho.

"Eu estava num lugar muito estranho, lembrava a faculdade, aquele corredor principal, só que não tinha igual o final do corredor tem, era tipo um mato, uma grama, um campo bem grande, lembra bastante um sítio que a minha família tem e eu estava lá com várias pessoas que eu não sei quem são, mas lá eu conhecia, sentia familiaridade e a gente ia lutar contra o outro, contra 
alguém por alguma coisa que a gente tinha razão pra ficar naquele corredor estranho e a gente sabia que a gente ia perder e a gente não tinha nada, não tinha arma nenhuma e eu falei: não, mas calma. Eu caí nesse espaço assim, do nada. Começou aí meu sonho, não, eu preciso de alguma arma se a gente vai lutar aí eu fui num lugar tinha uns negócios jogados no chão, aí eu peguei uma faca bem grande que eu usei, contextualizando, eu faço sandá, que é uma luta marcial, aí eu usei uma faca a semana passada que ela era bem grande, nada prático, mas era bem leve e era exatamente aquela, aí eu falei ah que legal, a faca do Dário está aqui, vou usar ela. Aí eu peguei. Mas tá, mas isso não é suficiente, eu preciso no mínimo prender meu cabelo. Aí eu fui para um banheiro que também é um banheiro que existe no sítio, estava no meio do IP o banheiro e eu fui na frente do espelho e comecei a puxar o meu cabelo assim pra cima pra amarrar e às vezes puxar o cabelo pra cima pra amarrar é muito chato e difícil porque ele não vem, você não consegue amarrar e aí eu fiquei tentando puxar o cabelo pra cima e fiquei tentando puxar o cabelo pra cima e ele ficava caindo e eu fiquei um tempo tão grande do meu sonho tentando puxar a porcaria do cabelo pra amarrar, pra fazer um rabinho de cavalo e foi muito estranho, fiquei irritada, que droga, não consigo prender a porcaria do meu cabelo e foi isso meu sonho, fiquei meia hora puxando o meu cabelo".

Figura 24: Fogueira Ideal / Acampamento com Platão

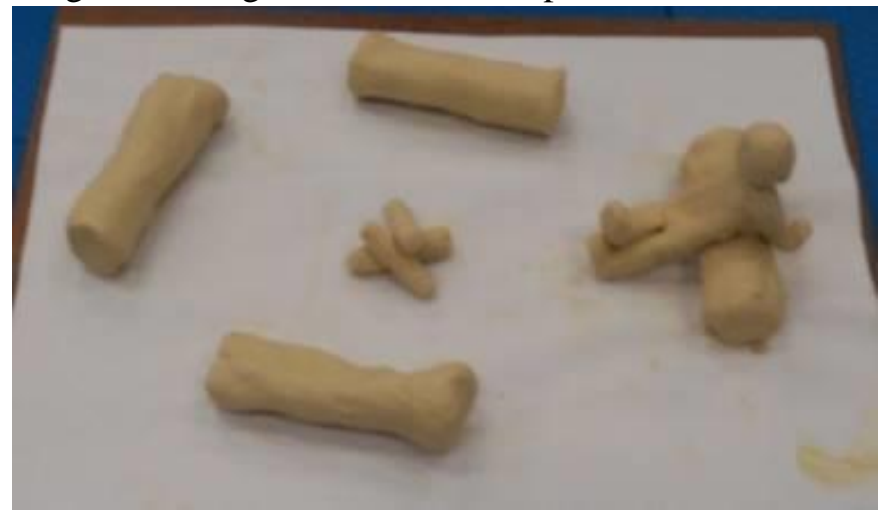

"O meu sonho começa com eu andando numa rua, está de noite e está bem vazia a rua e aí conforme eu vou andando na rua eu começo a ouvir uns tiros e daí pra me esconder eu acabo indo para uma casa mais próxima que está aberta, só que eu cago e vou para o meio do tiroteio que está tendo entre uns terroristas não especificados e um grupo de soldados da ONU que estavam protegendo uma bomba fudidona lá que no sonho eu não sabia o que que era. Eu sabia que era uma bomba, mas não sabia porque a gente estava defendendo, mas eles não podiam absolutamente pegar aquele treco e daí o pessoal da ONU chegou, me deu um rifle pra eu lutar também porque eu não tinha como fugir e eu cheguei, atirei um pouco, abati um ou outro e depois de um tempo a gente viu que tinha muito mais do que nós e dai a gente estava em quatro, contando comigo e um deles foi e levou um tiro, caiu. $O$ outro também e daí no fim, a gente tinha uns barris de explosivos dentro de uma garagenzona e a gente resolveu que bem, se eles não podem pegar essa bomba e a gente não pode proteger então melhor explodir essa bosta toda. E eu atirei no barril junto com o cara que tinha sobrado e tudo explodiu, daí tudo ficou branco, eu vi uns flashes loucos da minha vida passando muito rápido e daí eu tinha morrido com certeza. E aí eu apareci numa sala escura que tinha uma porta dupla. Era uma sala feita de concreto, só pedra mesmo. De um lado tinha uma porta escura, não era a porta que era escura, mas ela dava para um lugar escuro em que vinha um monte de barulhos estranhos, de monstros e tal. No outro tinha uma porta simples em que estava vindo uma luz bem clara dela e daí eu cheguei lá e tinha um amigo meu de longa data e uma garota antiga do meu colégio. Aí eu perguntei que porra é essa? Eu morri? Aquela porta dá pro céu e aquela dá pro inferno, é isso né? Aí eles ficaram não sei, não sei, não posso falar nada, não sei, não sei, daí eu pensei: 
talvez a porta dupla seja para eu voltar, mas eu não quero ir pro inferno. Aí eu entrei pra porta da luzinha e apareci num lugar que era tipo uma campina, bem grande, com um monte de cachoeiras e aquelas casinhas brancas com telhado vermelho bonitinho e dai eu fui até a casa mais próxima e no caminho eu encontrei um amigo de infância meu e a gente conversou e ele perguntou como que eu tinha vindo pra lá e eu contei, fiquei meio confuso, eu contei e aí eu perguntei e você e ele foi atropelado. Aí eu fui com ele, aí meio que deu um flash depois, era de noite, a gente estava em torno de uma fogueira, sentado em uns troncos que eram os bancos, era um monte de gente que eu não conhecia, não sabia, só tinha esse meu amigo de infância, um dos caras que estava comigo quando explodiu a bomba e daí também tinha o Platão lá. E daí a gente começou a conversar sobre como cada um veio e daí corta de novo. Foi basicamente isso".

Figura 25: Eu escolho você! / Desfecho animado

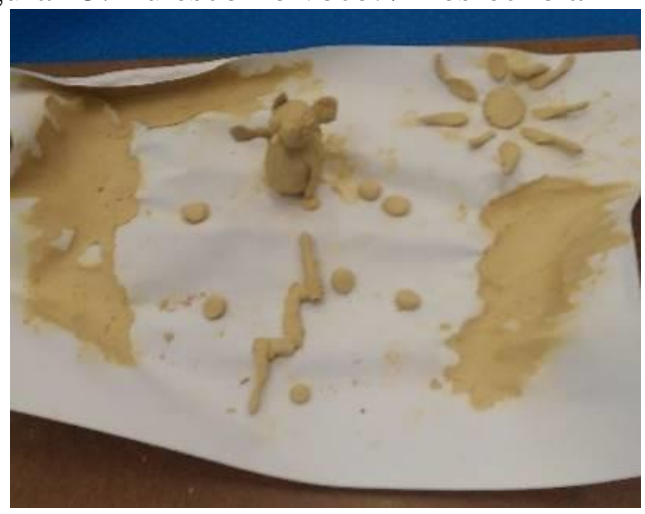

"É um sonho novo, muito bobo, mas que me deixou muito feliz. É como se eu estivesse assistindo televisão e visse várias cenas, como se fosse um desenho animado, alguma coisa assim, foi uma reunião de vários desenhos diferentes. Uma união de Pokémon, Naruto e Hamtaro, foi uma coisa muito bizarra, mas uma coisa muito divertida. Resumindo, é como se fosse a representação de um final de temporada de vê-los em que acontecem aqueles eventos tristes em que tem personagens que morrem, e alguns personagens que permanecem meio que ficam se lamentando a morte daqueles que foram, mas ao mesmo tempo ficam muito felizes porque resolveram, derrotaram todos os inimigos, estão em paz, esse tom meio agridoce. É sério. E eu gostei muito, foi muito divertido".

Figura 26: Sozinha / Solidão tempestuosa

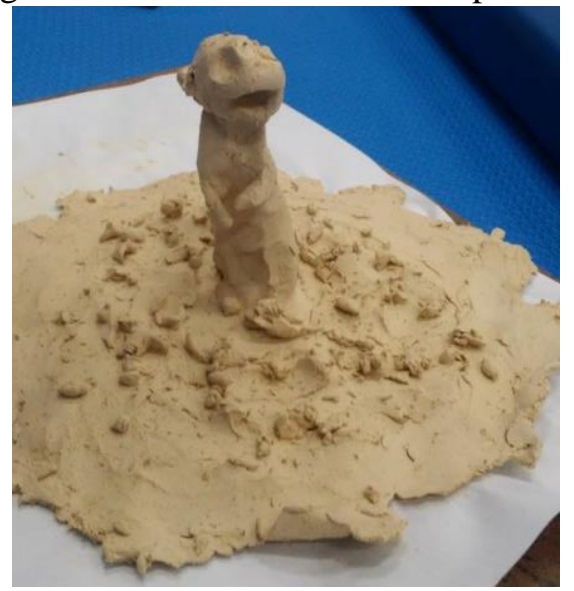

"O sonho que eu tive é um sonho muito antigo meu. Eu tive faz muito tempo, quando eu ainda estava estudando na minha escola que eu estudei o fundamental, e lá é assim, é bem grande. Tem uma parte, entre um prédio e outro tem um canil e se você tiver indo em direção ao prédio, 
da sua direita tem uma plaquinha e a pista de atletismo atrás e na esquerda tem uma horta, que é onde as crianças plantam. Eu lembro que eu estava lá no parquinho, geralmente tem muita gente lá só que eu não consigo lembrar se tinha pessoas ou não, mas eu lembro que eu estava lá, que eu estava na minha e que eu estava de uniforme, como se eu tivesse indo pra escola, mas aí do nada, o tempo virou, o tempo mudou, sabe estava tão normal, ok, sabe quando é bem apocalipse, o tempo mudou do nada, trovões, nuvem preta. Mas na hora que eu olhei ao meu redor, eu estava sozinha, não tinha mais ninguém e eu estava sozinha numa escola gigantesca que é impossivel estar sozinha, lá tem mais de 3 mil alunos, não tem como. Mas eu estava sozinha e me batia uma sensação muito ruim". 


\section{ANEXO J: SONHOS REFERENTES AO $2^{\circ}$ E $3^{\circ}$ ENCONTROS}

"Atrás de um muro não muito alto, estava observando alguns homens dentro de uma espécie de studio. Esses homens vestiam roupas e outros acessórios de outra época, parecia que pertenciam a algum grupo musical.

Enquanto observava o grupo, um homem negro (rosto não distinguível) começou a conversar comigo em outro idioma, entendi o que ele dizia (não lembro mais).

(...)

Estava dentro de um ônibus diante da porta de desembarque, então eu disse:

- Please, open the door!

(...)

Estava curiosa para saber se o banheiro havia mudado. Quando entrei nele pensei: "mas não mudou tanto assim”. Era um banheiro branco muito alto, haviam portas de metal (cor cinza) também altas, mas não havia outro detalhe que sinaliza-se que aquilo fosse um banheiro.

(...)

Em uma espécie de avenida, vi canteiros com plantações de legumes e de mandioca e pensei mais ou menos assim: "é mais ou menos como a D. I. tinha dito que era".

Obs: A Dona Iraildes é a única figura que reconheci no sonho".

"Aconteceu depois de minha cachorra ter falecido... Sonhei que a encontrava viva num prédio que morei quando criança. E logo a trouxe para junto da minha família, trazendo-a para meus familiares, eles ficaram felizes a princípio, contudo, depois que me virei, minha mãe deixou a cachorra sair. Corri atrás dela, mas não consegui pegá-la. Ao voltar indaguei a minha mãe porque ela tinha feito aquilo e ela me respondeu que eu tinha que deixá-la ir embora".

"Eu sonhei que estava em um ambiente fantástico: havia vários pilares de metal em uma caverna de lava. Eu estava em cima de um deles e parecia ter o poder de pular muito alto, de um pilar para o outro. Então eu vi minha mãe, em pé sobre um dos pilares. Eu precisava salvála e então fui pulando rapidamente pelos pilares até chegar a ela".

"Sonhei que estava com uma amiga. Estávamos sentados em um banco, só nós dois, mas próximo a este banco havia outros bancos, com pessoas desconhecidas; e os vários bancos formavam uma espécie de roda, ou algo como um hexágono. No centro dessa figura delimitada pelos bancos, ardia uma fogueira, muito intensa e brilhante, aparentemente saindo direto do chão de cimento (este me parece um detalhe relevante; o chão ser de cimento). Esta fogueira tinha uma forte cor violeta, mas ela lançava fagulhas douradas no céu noturno. Mas o aspecto mais importante daquela fogueira eram as grandes libélulas nas quais as fagulhas e centelhas se transformavam. O fogo liberava uma coluna espiralada de libélulas; milhares delas, em espirais, subindo e sem cessar. Olhar fixamente para a fogueira me deixa levemente zonzo $e$ então o cenário começa a mudar. As formas se dissolvem. Parece que todos os bancos estão girando - como se fosse um gira-gira - e as pessoas desconhecidas desaparecem. Minha amiga coloca a mão na minha coxa, e talvez por isso - como saber? - permanece comigo. As paisagens vão se transformando ao nosso redor, em sequência; só a roda de bancos permanece. Em um momento estamos em um lugar estranho cheio de bambuzais, e em alguns bancos há pessoas fumando e conversando baixinho. A seguir estamos em um grande salão com janelas imensas com vista para uma floresta de pinheiros e um céu estrelado. Depois estamos dentro de uma grande tenda cor-de-creme, de aspecto oriental. E assim vão os cenários, a mão dela sempre na minha coxa, até que em algum momento difuso eu acordo".

"Esse foi um sonho que eu tive várias vezes quando era mais nova. Por sorte, faz algum tempo que eu não tenho. Era sempre na sala do apartamento onde eu morei quando era menor. No 
canto da sala, ficava a cristaleira e a mesa, onde vários parentes (distantes, acho, dado que eu nunca consigo lembrar exatamente quem era) estavam sentados, comendo. Talvez por eu ser criança, eles pareciam enormes, e nunca olhavam para mim. $O$ que me deixava mais assustada era que eles comiam flores, rosas brancas e vermelhas, e que essas rosas eram meus pais depois de terem sido transformados por alguma coisa que eu não sei. E não importava o quanto eu tentasse gritar, o som nunca saía, e eu sempre acordava assustada”.

"Foi um sonho que eu tive quando eu era mais nova. Na verdade, eu não consigo lembrar se foi um sonho ou se foram dois, que por alguma razão se misturaram na minha mente agora. Mas eu lembro bem do cenário. Era uma espécie de grande salão aberto, sem teto. O céu era sempre nublado, mas não fazia frio. O salão era cheio de colunas, distribuídas simetricamente por todo o lugar. E era enorme, meio impossível de ver o fim. No fundo, tinha uma fonte d'água na parede, daquelas que a água sai da boca de um leão. E havia uma neblina fraca por todo o lugar. Uma vez tinha um homem me perseguindo lá, acho. Mas não dava muito medo. Era aventura, bem isso. Aquele lugar estava sempre imerso em uma aura de mistério e aventura. É agora que eu não lembro: uma vez eu tive impressão de ter ido parar lá depois de algum tipo de busca, jornada ou missão. Outra, eu lembro que ali era tipo uma parte escondida e misteriosamente interessante do térreo do prédio dos meus avós". 


\section{ANEXO K: RESPOSTAS DO QUESTIONÁRIO FINAL}

\section{Como foi participar do Grupo Vivencial de Sonhos?}

- $\quad$ "Foi uma experiência muito agradável, às vezes divertida, às vezes um pouco mais séria";

- "Eu acho que foi uma experiência positiva, tanto pela ideia em si de compartilhar os sonhos, quanto pela oportunidade de conhecer esse tipo de trabalho e as diversas formas de expressão possíveis";

- $\quad$ "Eu gostei bastante de participar do grupo, apesar de ter alguma contenção para lidar com grupos maiores elou com gente (razoavelmente) desconhecida, mas acho que foi basicamente por isso que consegui aproveitar o tempo no grupo. Quebrar um pouco com minha tendência natural de se isolar sempre faz bem para mim, mesmo que eu acabe saindo um pouco da zona de conforto. E também, a discussão de sonhos, que é um assunto em que me interesso bastante, foi muito legal e informativo";

- "Participar do grupo vivencial de sonhos foi uma experiência única $e$ enriquecedora, ainda mais para um recém-ingresso no curso de psicologia. Acredito que pude conhecer mais pessoas, compartilhar meus sonhos com elas e relaxar e processar os aspectos da minha vida que, de alguma forma, se retrataram dentro dos meus sonhos";

- "Foi uma experiência bem diferente e divertida";

- "Eu gostei muito de participar do Grupo Vivencial de Sonhos. Achei interessante, como já tinham comentado, como dava para perceber que a gente ia se consolidando cada vez mais como grupo, talvez até mesmo pelo fato de ter sido bem no começo do nosso primeiro ano... achei bem bacana! ";

- "Tive a oportunidade de compartilhar meus sonhos de formas diferentes";

- "Participar do grupo vivencial de sonhos foi uma experiência bastante interessante e enriquecedora, pois a partir das minhas próprias experiências e de meus amigos pude compreender um pouco sobre esse universo inconsciente e como ele mostra muitas vezes nossas angustias e medos que nem sempre são observáveis conscientemente”;

- $\quad$ "Para mim, foi muito gostoso participar do grupo. No começo, eu não sabia sobre o que falar quando eram levantadas questões, meus pensamentos não se dirigiam. Pensar em conjunto foi muito positivo nesse sentido pois nós ajudávamos uns aos outros a criar um caminho o qual cada um trilhava da sua forma, mas já não estávamos mais perdidos na inércia que eu sentia quando falava sobre os assuntos que discutíamos". 


\section{Qual foi o impacto de estar em um grupo falando sobre seus sonhos e ouvindo os sonhos dos demais? Como você se sentiu?}

- $\quad$ "Em alguns casos, em relação a alguns sonhos me senti desconfortável em compartilhar, mas no geral foi interessante. Gostei muito de ouvir os sonhos dos outros";

- "Contar o meu sonho foi muito legal, eu me senti bem animado em tentar interpretá-lo com a ajuda dos outros. Ouvir os dos outros também foi interessante; deu para criar relações com questões pessoais minhas. Por isso, acho que tive sentimentos variados, às vezes de compaixão, de alegria, de tensão...";

- "Eu senti uma espécie de conexão diferente com as pessoas com que compartilhei os sonhos, já que era algo que eu nunca tinha feito antes. Mas ainda assim, às vezes me senti incomodado e contido para contar meus sonhos para as pessoas (mas em outras vezes, senti bastante vontade de conta-los) ";

- $\quad$ "Ao falar de meus sonhos e ouvir os dos demais, na maioria das vezes me senti um pouco pesado (mas não de uma maneira necessariamente ruim), pois sei que os sonhos muitas vezes remontam ao dia a dia de cada um. Por vezes fiquei pensativo, refletindo sobre o que meus sonhos têm a dizer sobre mim e o que os dos outros falam sobre eles";

- $\quad$ "Foi muito bom encontrar um lugar em que eu pudesse compartilhar algo tão pessoal como sonhos sem ser julgada ou algo assim. Senti-me acolhida";

- $\quad$ "Achei bem impactante. Os nossos sonhos podem mostrar facetas nossas que nem a gente mesmo conhece direito, e muitas vezes um sonho que a gente já considerava pensado e repensado até o limite, quando colocado na roda, acabava ganhando mais uma interpretação, completamente nova. Eu me senti bem exposta (no bom sentido!) falando dos meus sonhos, afinal, nunca dava para saber exatamente onde a conversa ia levar";

- "Ao contar o sonho foi interessante ouvir outro ponto de vista. Ao ouvir os sonhos notei que os pontos que chamavam a minha atenção muitas vezes eram distintos dos fatos que chamavam a atenção dos outros colegas";

- $\quad$ "O impacto gerado foi de embate dos meus sonhos e sua ligação com a realidade, foi interessante e muitas vezes 'pesado' ouvir sonhos de meus colegas, porque alguns eram bem dificeis de lidar e possuíam um significado um tanto difícil de acessar conscientemente. Isso fez com que eu me sentisse um pouco pesada em alguns encontros, mas em outros foi uma sensação boa em compartilhar minhas experiências e ouvir a dos outros";

- "Acredito que foi uma experiência positiva, falando sobre meu sonho ou ouvindo os sonhos dos outros me ajudou a respeitar mais os sentimentos dos outros, além disso, também acho que pode ter fortalecido alguns vínculos";

- "Falar sobre o próprio sonho dá uma sensação muito libertadora, mesmo quando o sonho em questão já foi dividido com alguém anteriormente. Ouvir os sonhos dos 
outros, ao mesmo tempo que é demonstração de confiança por parte do sonhador em dividir algo tão íntimo, me provocava uma grande curiosidade quanto ao fantástico produzido pela mente dos outros, que sempre viaja além das barreiras que são impostas quando estamos acordados e que nem percebemos que estão lá, a não ser quando tentamos contar o sonho utilizando uma linguagem pautada no que é real".

\section{Qual dos recursos expressivos/artísticos apresentados no grupo (escrita, desenho, relato verbal e modelagem) você considera que contribuiu para a compreensão dos seus sonhos? Por quê?}

- $\quad$ "Acho que nenhum. Eu prefiro fazer uma análise introspectiva mental. Mas é legal representá-los de outras formas, especialmente por meio da modelagem”;

- "Gosto muito de escrever e acredito que essa seja uma das melhores formas de eu me expressar (não apenas em se tratando de sonhos). Não tenho facilidade com desenhos e me confundo quando falo... A modelagem também foi bem legal mas mais pela questão artística, de possibilitar várias formas diferentes que podem ir mudando sem dificuldade";

- $\quad$ "Acredito que tenha sido a modelagem, já que também foi a com maior interação entre o sonhador e a expressão artística, além de também ter o aspecto da discussão dos modelos posteriormente, o que foi muito bacana. Também foi a atividade da qual mais gostei, então acho que tive uma conexão mais forte com o que estava ocorrendo (e isso deve ter ajudado bastante)";

- $\quad$ "Não pude participar do exercício de modelagem, mas o que mais senti que me ajudou a expressar meus sonhos foi o desenho, pois havia uma paleta de várias cores diferentes e uma margem quase infinita de possibilidades de representação. Contudo, também me senti muito confortável contando meus sonhos de maneira oral, pois assim parece ser mais fácil descrever como eu realmente me sentia no sonho";

- $\quad$ "Acho que talvez o relato, não tanto pela mídia usada, mas pela possibilidade de compartilhar o sonho de uma forma mais pessoal (me expondo menos). Também foi bom porque a falta de habilidades artísticas pode inibir um pouco";

- "Para mim, foi a modelagem. Para fazer o modelo, foi necessária uma ampliação da forma de ver o relato que a escrita, por exemplo, não exigiria: é como se a modelagem já levasse a uma reflexão sobre o sonho. Não dá para narrar a "história" do sonho, linear e descritivamente, com modelagem: é necessário escolher um elemento e trabalhá-lo. E trabalhar esse elemento, também, só é possível depois de pensar sobre ele, porque não é tão fácil (pelo menos, para mim não é) criar um relato detalhado com um modelo tridimensional quanto o é com palavras";

- $\quad$ "Relato verbal. Porque com esse recurso expressivo pude refletir e fazer uma autoanálise do sonho enquanto o compartilhava"; 
- "O recurso, o qual eu mais gostei foi o relato verbal, acredito que enquanto eu falava pra outra pessoa meu sonho podia perceber certas significações que quando estava pensando no sonho sozinha não conseguia enxergar. Ao falar parece que revivia as imagens com mais nitidez e experimentava a sensação de estar no sonho novamente";

- "O relato verbal, pois foi a forma como consegui descrever melhor o sonho e transmitir mais o que eu senti quando o vivi”;

- $\quad$ "Creio que os meios expressivos que mais me satisfizeram na compreensão do meu sonho foram o desenho e a escrita. O desenho porque a imagem que criei sem muito pensar foi capaz de expressar o sonho muito bem, mesmo que o significado se restringisse a mim uma vez que ela não representava completamente a sua história. Já a escrita me foi interessante pois quando reli meu relato percebi algumas palavras repetidas. Elas remetiam a coisas para as quais eu não percebia a importância que dava antes de notar essa repetição".

\section{Você acredita que essa experiência pode ter relevância para sua formação como psicólogo? Por quê?}

\footnotetext{
"No futuro, creio que sim. Poderei realizar abordagens semelhantes com meus pacientes/clientes";

- $\quad$ "Sim, acredito que essa atividade foi extremamente importante para minha formação como psicólogo. Trabalhar a questão dos sonhos, a capacidade de ouvir o outro, de se abrir um pouco também, tudo isso acho que são características essenciais para mim";
}

- $\quad$ "Sim, já que revela mais sobre mim e também sobre o mundo dos sonhos (mesmo que em um curto período de tempo). Além de introduzir para um assunto bem recorrente e vital da formação do psicólogo, também ajuda a me conhecer melhor, o que eu acredito que vá ajudar no entendimento dos outros mais para frente (e a lidar comigo mesmo também) ";

- $\quad$ "Acredito que essa experiência foi muito importante para minha formação pois foi meu primeiro contato com um grupo de sonhos, feito logo no início da graduação, e me mostrou várias ideias e formas de representação de sonhos, como o desenho, a escultura, etc. Também foi legal ouvir os sonhos dos outros participantes e tentar analisá-los, o que foi muito incentivado",

- $\quad$ "Eu imagino que sim, porque é mais fácil aprender a noção de discrição e (de não comentar nada fora da sala) em um grupo de amigos do que direto numa consulta";

- "Sim. Primeiro, porque nós falamos de sonhos, coisa que eu imagino que vá fazer muito quando estiver exercendo a profissão. Além disso, falamos de temas muito pessoais e sensíveis, e tomamos sempre o cuidado de fazê-lo sem sermos invasivos ou 
gerarmos desconforto. E, além disso, eu gostei muito da dinâmica dos encontros, e espero poder levar isso para a minha formação enquanto psicóloga, principalmente porque eu penso em trabalhar com grupos de pessoas";

- "Sim. Lembrarei do grupo quando estudar sobre os sonhos";

- "Sim, a partir do momento que buscar significação nos sonhos possa ser um instrumento a mais para o entendimento do ser humano e de seus anseios, que é a grande proposta da psicologia como um todo";

- $\quad$ "Sim, os sonhos podem ser uma ferramenta fundamental na prática clínica e entrar em contato um pouco com eles já no início da graduação pode ajudar a ter uma outra visão sobre eles quando de fato forem alvo dos estudos na sala de aula";

- $\quad$ "Sim, ao meu ver esta experiência me proporcionou uma forma de encarar a questão dos sonhos muito nova para mim e muito interessante, em parte por conta das análises feitas sob a direção da Pauline, com as quais aprendi algo, em parte pois me mostrou o quanto tem a acrescentar o pensamento em conjunto na discussão desse assunto".

\section{Qual era a sua expectativa em participar do grupo vivencial de sonhos?}

- "Eu achava que nós iríamos trabalhar mais a interpretação formal dos sonhos, e que todos teríamos a chance de expor nossos sonhos ao grupo";

- $\quad$ "Acredito que minha expectativa era a de encontrar um lugar para discutir $e$ interpretar sonhos, mas mais na ideia da comunicação verbal";

- "A minha expectativa inicial era a de ser um grupo de compartilhamento de sonhos, só que de uma forma mais "tradicional", em que só contaríamos sonhos aleatórios e ocorreria uma análise logo em seguida. Felizmente foi bem mais divertido, criativo e iluminador do que eu pensava inicialmente";

- $\quad$ "Minha expectativa era mais de me ver um grupo de interpretação de sonhos, onde haveria alguém que conduziria esse processo todo. Contudo, me surpreendi em ver um grupo de compartilhamento de sonhos e experiências e de representação destes, onde todos tinham voz para falar como se sentiam e o que sentiam sobre o sonho de todos";

- $\quad$ "Achei que passaríamos mais tempo analisando os sonhos do que colocando-os no papel (ou na argila, ou no que fosse), mas gostei da experiência da maneira como ela foi conduzida...";

- $\quad$ "Eu sempre gostei muito de falar de sonhos, então minha expectativa com o grupo (que foi bem correspondida!) era de ter um espaço para poder falar sobre sonhos com pessoas que compartilhassem esse interesse"; 
- “Tinha a expectativa de encontrar um significado mais concreto para o sonho”;

- "Minha expectativa era conhecer mais sobre o universo de entendimento do sonho e buscar novas experiências com isso";

- $\quad$ "Acho que a expectativa foi cumprida, esperava somente um espaço para poder compartilhar meus sonhos";

- "Me inscrevi para participar do Grupo apenas com a intensão de ouvir um pouco sobre os sonhos de outras pessoas e, eventualmente, compartilhar algo meu. Não tinha grandes expectativas quanto a encontrar significados ou mesmo quanto às dinâmicas feitas para relaxamento e interação do grupo".

\section{Antes da sua participação no grupo vivencial de sonhos como você entendia e lidava com seus sonhos? E após ter participado do grupo, houve alguma mudança?}

- "Na verdade, acho que não houve. O grupo não me fez ver os sonhos de uma forma diferente. $O$ que mudou foi a minha noção de como reagimos ao contar e expor nossos sonhos. Dependendo do sonho a postura e a linguagem da pessoa muda, e ela "manipula" o que conta";

- $\quad$ "Eu não costumava dar muita importância aos meus sonhos, tanto que não lembrava muito dos que eu já tinha sonhado. Depois do grupo, eles me passaram a interessar um pouco mais, tenho começado a anotar alguns e fico animado quando tenho um sonho longo ou com grandes significados para mim”;

- $\quad$ "Eu normalmente não ligava muito para eles caso fossem mais simples ou "bobos", mas quando eu tinha um sonho mais impactante, em que eu achava que tinha ocorrido por causa de uma situação na minha vida, eu tentava achar essa conexão e ver o porquê de eu ter sonhado ele. Mesmo que isso não trouxesse alguma mudança significativa, eu normalmente me sinto melhor quando consigo encontrar essa ligação. Depois do grupo isso continua o mesmo, mas como ainda não se passou muito tempo, acho que é cedo demais para dizer se isso irá mudar";

- "Eu sempre procurei contar meus sonhos a alguém, pois sei que eles são importantes para a compreensão do indivíduo. Contudo, após participar do grupo vivencial de sonhos, descobri outras formas de representação, como a pintura e a escrita. Talvez assim fique mais fácil para eu lembrar de meus sonhos futuros se puder sempre concretizá-los de alguma forma";

- $\quad$ "Como eu normalmente não consigo me lembrar dos meus sonhos, acho que eles não causavam um grande impacto; agora comecei a prestar um pouco mais de atenção, mas não houve grandes mudanças..."; 
- "Eu tento ao máximo prestar atenção nos meus sonhos e lembrar deles de alguma forma, mas eu sempre relacionava-os com coisas que estavam acontecendo no momento em que eu sonhava. Com os encontros, eu passei a pensar mais no que eles significam em termos mais "amplos", relacioná-los com coisas que aconteceram faz tempo ou com características pessoais minhas. Agora, eu estou motivada a tentar pensar em novas maneiras de fazer isso (antes eu só escrevia), para conseguir, no fim, pensar nos meus sonhos de um modo novo";

- "Achava os sonhos intrigantes e ficava pensando no que poderiam significar. Houve mudança, passei a compartilhar meus sonhos com outras pessoas e perguntar o que chamava a atenção delas";

- $\quad$ "Antes eu apenas lembrava, mas não dava muita importância, depois do grupo dos sonhos pude perceber que na verdade eles revelam bastante sobre o que vivemos $e$ como isso é percebido pelo nosso inconsciente. A partir de agora dou mais importância para os sonhos que tenho, inclusive durante todo o tempo do grupo não tive muitos sonhos e se tive os esqueci, mas parece que depois que acabaram os encontros estou tendo muito mais sonhos do que antes";

- $\quad$ "Sempre os entendi como parte fundamental da minha vida, principalmente pelo fato de já ter feito análise com psicanalistas que usavam muito desse recurso, porém, após grupo eu concedi ainda mais importância aos sonhos";

- "Após a experiência passei a analisar meus sonhos olhando para as partes, para as coisas que os integram, a tentando extrair o seu significado para mim. Além disso, passei a ter uma intenção maior de compartilhá-los com os outros e escutar o que eles podem ter a dizer sobre meu sonho".

\section{Você tem alguma sugestão ou comentário?}

- $\quad$ "Acho que seria interessante fazer encontros de 2 horas, pois sempre ficávamos além do horário. Outra ideia é focar mais nos sonhos e na discussão sobre eles, dando mais espaço para todos e não só alguns compartilharem com o grupo";

- "Não tenho sugestões/comentários",

- $\quad$ "Eu gostaria de ter passado um pouco mais de tempo com a argila, fazendo o que eu tivesse vontade, sem um objetivo concreto de início. Mas como eu sei que isso não é exatamente ligado aos sonhos, não sei o quão relevante é essa sugestão";

- $\quad$ "Acho que seria interessante se houvesse um tempo maior em cada encontro, para dar mais tempo de fazer todas as atividades. Também seria legal uma forma de representação teatral dos sonhos. Fora isso, achei o grupo muito bem conduzido e as atividades muito bem pensadas e executadas"; 
- $\quad$ "Acho que ou as sessões devessem ser mais longas ou devêssemos passar menos tempo discutindo o que achamos da experiência e mais tempo nela própria... Talvez num ambiente em que não se precise de um feedback a cada encontro, funcione melhor";

- "Queria agradecer muito pelos encontros! Gostei muito da dinâmica e das coisas que a gente discutiu, acho que abriu espaço para nós mesmos propormos mais espaços para discussões assim, e foi uma experiência bem diferente! ”;

- $\quad$ "Agradeço a oportunidade de participar de seus estudos, peço desculpas por algo que tenha dito ou feito que possa ter causado algum constrangimento e qualquer coisa que precisar é só entrar em contato";

- $\quad$ "Meu único comentário é que gostei muito de participar desse grupo dos sonhos e vivenciá-los de uma nova maneira me deu nova perspectiva sobre os significados dos sonhos";

- "Não, acho que o grupo satisfez minhas expectativas";

- "Gostaria de ter podido ouvir mais sonhos dos colegas e talvez contar mais sonhos meus também, mesmo que não fossemos analisar todos. Assim, seria muito interessante um tempo maior nas reuniões. Fora isso, foi muito legal ter tido essa vivência”. 